\title{
Moving back or moving forward?
}

Citation for published version (APA):

van Houte, M. (2014). Moving back or moving forward? Return migration after conflict. [Doctoral Thesis, Maastricht University]. Boekenplan. https://doi.org/10.26481/dis.20141120mh

Document status and date:

Published: 01/01/2014

DOI:

10.26481/dis.20141120mh

Document Version:

Publisher's PDF, also known as Version of record

\section{Please check the document version of this publication:}

- A submitted manuscript is the version of the article upon submission and before peer-review. There can be important differences between the submitted version and the official published version of record.

People interested in the research are advised to contact the author for the final version of the publication, or visit the DOI to the publisher's website.

- The final author version and the galley proof are versions of the publication after peer review.

- The final published version features the final layout of the paper including the volume, issue and page numbers.

Link to publication

\footnotetext{
General rights rights.

- You may freely distribute the URL identifying the publication in the public portal. please follow below link for the End User Agreement:

www.umlib.nl/taverne-license

Take down policy

If you believe that this document breaches copyright please contact us at:

repository@maastrichtuniversity.nl

providing details and we will investigate your claim.
}

Copyright and moral rights for the publications made accessible in the public portal are retained by the authors and/or other copyright owners and it is a condition of accessing publications that users recognise and abide by the legal requirements associated with these

- Users may download and print one copy of any publication from the public portal for the purpose of private study or research.

- You may not further distribute the material or use it for any profit-making activity or commercial gain

If the publication is distributed under the terms of Article $25 \mathrm{fa}$ of the Dutch Copyright Act, indicated by the "Taverne" license above, 


\section{Moving Back or \\ Moving Forward?}

Return migration after conflict

Marieke van Houte

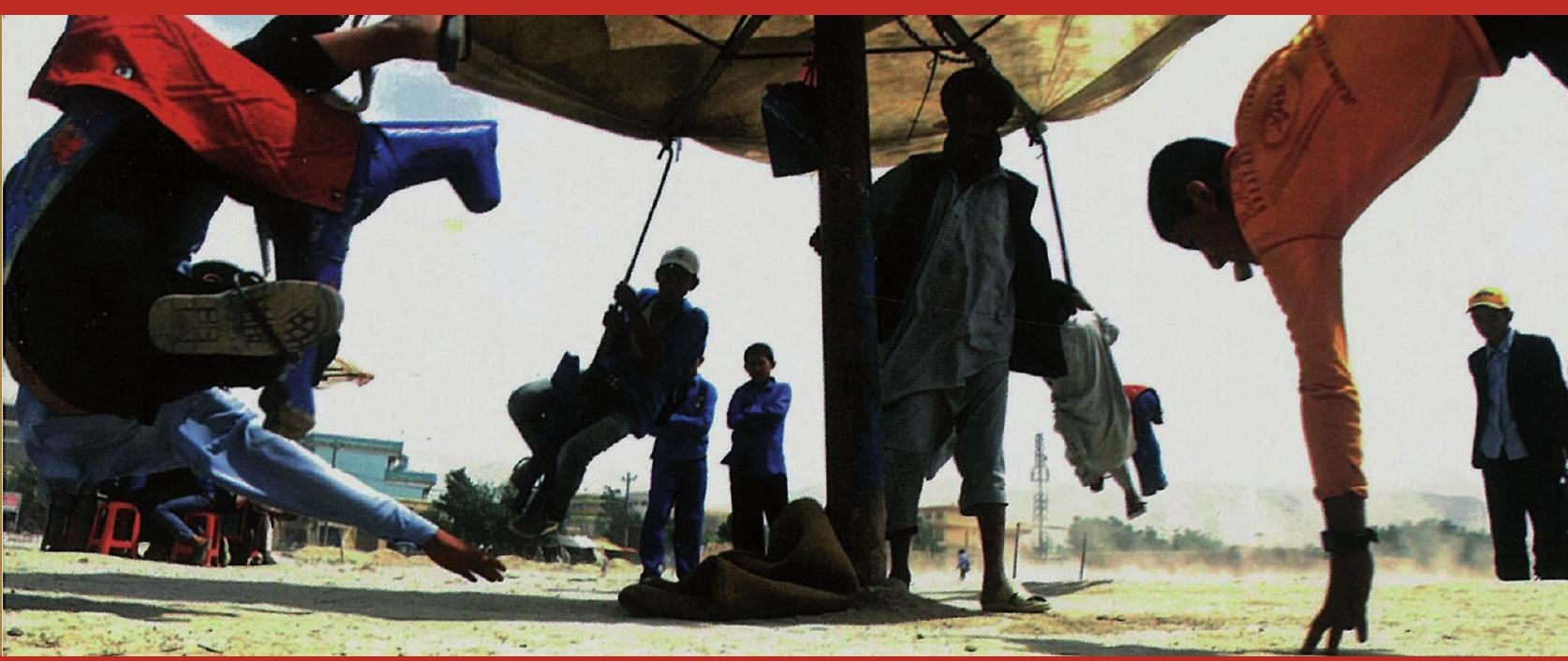


The Maastricht Graduate School of Governance (MGSoG) was founded in September 2004 at Maastricht University. The mission of the School is to train specialists who combine a high level of academic scholarship with leadership, in order to strengthen democratic governance in domestic and international organizations, by focusing on policy analysis, risk assessment, policy design, monitoring and evaluation, and methodologies and techniques of policy research.

MGSoG provides multi-disciplinary top-academic training in the heart of Europe. This is achieved by building on the academic resources of the different faculties at Maastricht University as well as those of several foreign partners. From 2011 onwards, the School has become part of the United Nations University, strengthening further its international training and research network while building on the expertise of UNU-MERIT the Maastricht based research institute of the UNU. To guarantee both high academic quality and policy relevance, the MGSoG is closely involved with an extensive academic and professional network, including highly recognized organizations such as the OECD, ILO, UNDP, WB, IMF and EU. 


\section{Moving Back or Moving Forward?}

Return migration after conflict 


\section{Colophon}

Illustration cover: Kuchi films

Figures:

Printing:

Karlijn Driessen

Boekenplan, Maastricht

Financial support by Cordaid, PSO and UNU-MERIT is gratefully acknowledged.

ISBN: 9789086663491

(C) Marieke van Houte, 2014. All rights reserved. No part of this thesis may be reproduced or transmitted in any form or by any means without prior written permission from the author. 


\title{
Moving Back or Moving Forward?
}

\section{Return migration after conflict}

\author{
Dissertation \\ to obtain the degree of Doctor at Maastricht University, \\ on the authority of the Rector Magnificus, \\ Prof. Dr. L.P.P. Soete \\ in accordance with the decision of the Board of Deans, \\ to be defended in public \\ on Thursday 20 November 2014, at 10.00 hours
}

by

Marieke van Houte 


\section{Supervisor}

Prof. Dr. Khalid Koser

Co-supervisor

Dr. Melissa Siegel

Assessment Committee

Prof. Dr. Ronald Skeldon (chair)

Prof. Dr. Jean-Pierre Cassarino, European University Institute

Prof. Dr. Hein de Haas

Dr. Ceri Oeppen, University of Sussex 


\section{Contents}

$\begin{array}{ll}\text { Figures, tables and appendices } & 7\end{array}$

Acknowledgements 9

1. Introduction 13

1.1 The rise of return migration as a multi-tool for policy 13

1.2 Research question 22

1.3 Theoretical perspectives on return and development 23

1.4 Outline of thesis 28

1.5 Conclusion 31

2. Methodology 33

2.1 Introduction 33

2.2 Research design: a two-phase study 34

$\begin{array}{lll}2.3 & \text { Research techniques } & 37\end{array}$

2.4 Methodological challenges and ethical considerations $\quad 44$

$\begin{array}{lll}2.5 & \text { Conclusion } & 47\end{array}$

3. Determinants of post-return embeddedness 53

3.1 Introduction 53

3.2 Return migration and embeddedness $\quad 55$

$\begin{array}{lll}3.3 & \text { Results } & 59\end{array}$

$\begin{array}{lll}3.4 & \text { Conclusion } & 69\end{array}$

$\begin{array}{ll}3.5 & \text { Moving forward }\end{array}$

4. Afghanistan 83

4.1 Why Afghanistan as a case study? 83

4.2 A political history of conflict, migration and return 83

4.3 Afghan migration to Europe $\quad 92$

4.4 Conclusion 96

5. Meanings of and motivations for return 99

$\begin{array}{lll}5.1 & \text { Introduction } & 99\end{array}$

5.2 Structure and agency, capacities and desires in return 101

5.3 Structural reality of Afghan conflict and migration 105

$\begin{array}{ll}5.4 & \text { Narratives of return } \\ & 107\end{array}$

5.5 Discussion and conclusion 112 
6. The hierarchization of migration 115

$\begin{array}{lll}6.1 & \text { Introduction } & 115\end{array}$

6.2 Multidimensional embeddedness 116

6.3 'Waves' of Afghan migration 118

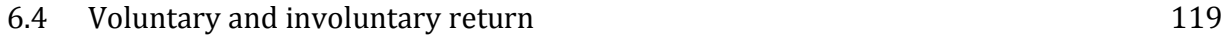

$\begin{array}{lll}6.5 & \text { Discussion } & 125\end{array}$

$\begin{array}{ll}6.6 \text { Conclusion } & 126\end{array}$

7. Love (n)or marriage $\quad 129$

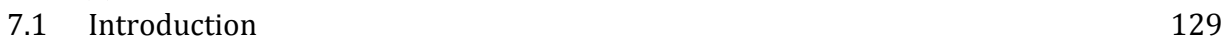

7.2 Marriage, sexuality, gender, migration and change 131

7.3 Discourses of marriage, sexuality and gender 132

$\begin{array}{ll}7.4 & \text { Negotiating love or marriage } \\ 7.5 & \text { Conclusion }\end{array}$

$\begin{array}{lll}7.5 & \text { Conclusion } & 142\end{array}$

8. Returnees for change? $\quad 145$

$\begin{array}{lll}8.1 & \text { Introduction } & 145\end{array}$

8.2 Return migrants as agents of change? 146

8.3 Challenges of 'post-conflict' Afghanistan 149

8.4 Identification with conflict and potential to be agents of change 152

$\begin{array}{lll}8.5 & \text { Conclusion } & 161\end{array}$

9. Conclusion 165

9.1 Return migrants as agents of change? 165

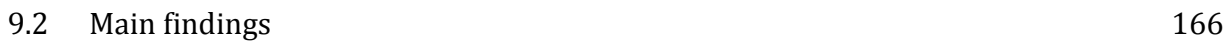

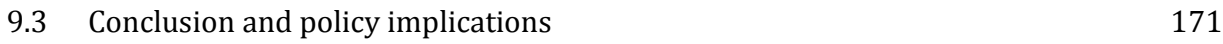

$\begin{array}{lr}\text { References } & 179\end{array}$

$\begin{array}{ll}\text { Glossary } & 193\end{array}$

$\begin{array}{ll}\text { Valorization } & 195\end{array}$

$\begin{array}{ll}\text { Samenvatting (Dutch summary) } & 199\end{array}$

$\begin{array}{ll}\text { About the author } & 207\end{array}$ 


\section{Figures, tables and appendices}

\section{Figures}

1.1 Return, development and peace-building goals, needs and policies 16

1.2 Organization of thesis 30

3.1 Analytical framework of determinants of multidimensional embeddedness 58

4.1 Annual return to Afghanistan 2002-2013 88

4.2 The Afghan diaspora in 2000/2001 90

5.1 Interplay between structure, agency, desire and capacity 103

9.1 Development potential of and development budget for return migrants 174

9.2 Disentangling return, development and peace-building goals, needs and policies 176

\section{Tables}

1.1 Thematic, conceptual, methodological and regional focus of each chapter 29

2.1 Numbers of respondents per country in comparative study $\quad 35$

2.2 Respondents in Afghan return migration study - Involuntary return migrants 36

2.3 Respondents in Afghan return migration study - Voluntary return migrants 37

2.4 Key informants interviewed in the six countries under study 42

$\begin{array}{lll}3.1 & \text { Reason(s) for migration } & 60\end{array}$

3.2 Circumstances of return migration $\quad 60$

3.3 Frequencies of type, source and timing of return assistance 61

3.4 Post-return assistance received by respondents 62

3.5 Embeddedness scores in percentage of respondents 62

3.6 Type of housing pre-migration and post-return 63

3.7 Employment pre-migration and post-return 63

3.8 Determinants of post-return embeddedness across the six countries 67

4.1 Afghan mobility: Afghan IDPs, migrants and return migrants 92

4.2 Total asylum claims of Afghans in 44 industrialized countries 92

5.1 Structures, capacities and desires on each dimension of embeddedness 104

6.1 Types of return migrants in the case study 118

6.2 Circumstances of departure of voluntary and involuntary return migrants 119

6.3 Post-return circumstances of voluntary and involuntary return migrants 121

6.4 Patterns of migration and return $\quad 125$

7.1 Characteristics of 'Afghan' and 'European' discourses of marriage 133

7.2 Return motivation, gender and marital status of respondents 134

7.3 Spaces of negotiation based on capacities and desires regarding marriage, 135 sexuality and gender norms

8.1 Assumptions of return migrants' characteristics, impact and Afghan context 151

\section{Appendices}

2.1 Construction of embeddedness in comparative study 48

2.2 Main coding for Afghan return migration study 50

$\begin{array}{lll}3.1 & \text { Regression analysis of comparative study } & 72\end{array}$ 
Ausländer sind wir alle - fast überall We are all foreigners - almost everywhere

German bumper sticker

Thuis daar zedde baas Home is where you are in charge

Charles van Houte 


\section{Acknowledgements}

The journey that eventually led to this thesis started in a packed minivan ${ }^{1}$ and a rather disorganized encounter with a Bosnian family of return migrants, which provoked a long-standing interest in and respect for returnees' life stories. I thank Kees Kentin for taking me on that trip and for being an endless source of inspiration. The bumper sticker I peeled off your door reminds me of you and became a personal motto in my work.

I realize how much we asked from the participants in this study in six countries across the world, and particularly in Afghanistan, when we simply asked them to tell the story of their life, because these were never easy stories to tell and there were no direct benefits to gain. Thank you for sharing your beautiful, painful, funny and unforgettable stories. I have learned a lot from you along the way and you were the main motivation for completing this thesis. Although I cannot mention your names here, this book is only one way of making sure your voices are heard. I dedicate this thesis to you.

My 'golden' team of supervisors was the best I could wish for, and truly complementary. Melissa Siegel, I thank you for your trust and for letting me become part of your wonderful team. Once on board, your encouragement and tight deadlines kept me going, while your insistence on clear, structured writing helped me to describe the complexity of migration. Your seemingly endless energy, ambition and generosity are an unforgettable example. Khalid Koser, it has been very inspirational for me to work with an academic example whose work I had been reading for a long time. Thank you for sharing your experience and for your ever-constructive feedback, which helped me to see the bigger picture and relate my work better to existing discussions. Tine Davids, you have been my mentor since I wrote my Master's thesis under your supervision, and my academic career started under your wings. I thank you for your endless encouragement to do more in-depth analysis beyond the obvious, and for your loyalty and enthusiasm as my unofficial co-supervisor.

Many thanks to the members of the assessment committee: Ronald Skeldon, JeanPierre Cassarino, Hein de Haas and Ceri Oeppen. It is an honour and a privilege to have my thesis read and approved by four scholars whose work I highly appreciate.

Apart from supervisors and committee members, several people commented on earlier drafts of chapters of this thesis during seminars and conferences, or over an informal coffee. Special thanks are due to Özge Bilgili, Ayla Bonfiglio, Kim Caarls, Teun Eikenaar, Remco Heijmans, Sara Kinsbergen, Arjen Leerkes, Joyce Römkens and Marieke Wissink for reading chapters and providing extremely valuable feedback.

\footnotetext{
${ }^{1}$ Special thanks to the Bosnian farmer whose tractor prevented the minivan from gliding off that icy cliff, which could have ended the journey there and then.
} 
My time at the department of Cultural Anthropology and Development Studies (CAOS) at Radboud University Nijmegen, where I worked as a researcher in migration between 2007 and 2013, was a formative period in my life. The CAOS 'young dogs' were invaluable for some dark humour, authentic fries and drinks at and outside of work. Anouk, Anouka, Bart, Celina, Jelmer, Judith, Rik, Roldan, Sara, Therese, Thomas, Warara, Willem, Xuefei and many others, thank you for your friendship. Catrien, Francien, Hans, Henk, Lau, Luuk, Saskia, thanks for sharing your experience and support.

The migration and development group at the Maastricht Graduate School of Governance and UNU-MERIT gave me the opportunity to write my PhD thesis in 2013. I thank the School for their trust and for facilitating one great year of inspired writing and discussion in a vibrant and dynamic environment. Becoming part of a hardworking, ambitious, passionate and extremely kind team felt like a privilege and gave me a boost of energy, which made writing a PhD thesis suddenly fun and almost easy. Thanks for great companionship, support and inspired discussions in Maastricht. Special thanks to everyone in the always vibrant 'migration room': Craig, Elaine, Georgina, Jennifer, Katie, Katrin, Michaella, Özge, Silja, Sonja and many others. In addition, Eveline, Mindel, Susan and Herman, your support has been invaluable.

At the same time, when looking for office space in Nijmegen, what I found was an abundance of shared inspiration at the Truth Mockery (Waarmakerij) and Metterswane, and some wonderful people whose creativity and innovativeness is contagious and inspirational.

This thesis was made possible with the generous contributions of UNU-MERIT and the Dutch development organizations Cordaid and PSO. I would like to thank Joep van Zijl, Henk Hofste, Bob van Dillen and Godefroid Nimbona of Cordaid for your extraordinary dedication to make the research for this thesis possible.

Thanks to Cordaid's partners in Togo, Sierra Leone, Armenia, Bosnia and Herzegovina, Vietnam and Afghanistan for the facilitation of the first part of this study. I would also like to thank the researchers Mireille de Koning, June de Bree, Maaike Derksen, Moira Galloway, Alice Johansson and Machteld Kuyper for their dedicated contributions to that first part, Theo van der Weegen and Kim Caarls for their statistical support and Tine Davids, Ruerd Ruben and Valentina Mazzucato for their supervision.

My thanks are again due to Cordaid Kabul for facilitating this research a second, intensive time. Thanks to Milan, Jain and Selva for sharing their house with me. I thank my translators Walid Fazly and Reza for their dedication and friendship, and also the members of the Afghan NGO AHRDO for their inspiration and support during the fieldwork.

These years of travelling, talking, thinking and writing about what makes 'home' in the lives of migrants also made me look back to my own background. I think with gratitude of the friends in my life. Thanks for creating little bites of home, whether 
over intimate dinners with close friends, extravagant barbeques with a bunch of fun people, or snacks of brief but meaningful encounters while travelling.

Hans Fabrie, right in-between the 'friends' and 'family' paragraph, thank you so much for being a navigator through that nasty storm along the way, which helped me come out stronger than ever.

The image of my roots is embodied in my grandfather who, at the age of 99, did not need academic research or world travelling to understand the essence of 'home' and summarize it in a single sentence. The phrase reminds me of the simplicity of wisdom, or the wisdom in simplicity, and of my grandfather.

Dear parents, thank you for encouraging us to do the best we could with our abilities and interests, whatever that would be, no matter how far it would take us and no matter how much that would hurt. The unconditional pride and confidence that you have in me is amazing. Joris and Annemarie, I am at least as proud of you as you are of me. It is a great joy and of Ocho importance to be part of your, Gijs' and Siebe's lives.

Remco, with you in my life, life is so much lighter and richer, and so much more than a PhD thesis or work. In Lonely Planet language, you are the awe-inspiring and jawdropping highlight of this journey. Not everything I want to tell you would be appropriate to write here. But after years of research, my personal conclusion is this: home is where you are.

Marieke van Houte

November 2014 
What did we want? We want the world smaller and bigger and just the same but advancing. We don't know what we want.

Dave Eggers - You shall know our velocity! p. 273. 


\section{1 \\ Introduction}

Return migration, development and peace-building

\subsection{The rise of return migration as a multi-tool for policy ${ }^{1}$}

'When migrants return home after conflict, they will contribute to development and peace-building'. This optimistic mantra in current European national policies (ICMPD and ECDPM 2013) is the result of a changing discourse over the past 25 years with regard to migration. In this globalizing world, it has become common ground that development, security and mobility are interdependent. As a result, industrialized host states now see modern migration movements as instruments for policy that (1) need to be managed, controlled and regulated to (2) defend domestic security and welfare and (3) promote international development and peace-building (Carling 2002, De Haas 2006, Duffield 2006, Skeldon 2008, Raghuram 2009, De Haas 2010, Castles, De Haas, and Miller 2014, 82, 318).

Efforts by host states to manage these three overlapping goals have led to the formulation of migration and development policies. Within this policy domain, return migration has evolved from being 'the great unwritten chapter in the history of migration' (King 2000, 7) to being a multi-tool that is used to work towards all these goals at once (see Skeldon 2008). Gradually, return migration came to be considered as both a movement back to normal, which restores the pre-conflict natural and social order, and a movement forward to change, in which returnees contribute to development and peace-building (Koser and Black 1999, Faist 2008).

Although global discussions on the link between migration and development have focused on successful economic migrants, countries throughout the European Union have expanded this link to encompass the return of refugees, failed asylum seekers and undocumented migrants ${ }^{2}$ (ICMPD and ECDPM 2013). However, several scholars wonder why and how some of the world's most exploited people should contribute to development when official aid programmes have failed (Castles and Miller 2009, 58). In addition, the question is raised why returning migrants from industrialized countries, who constitute a minority of all migrants, are targeted (Skeldon 2008).

This chapter introduces the debate on the linkages between return migration, development and peace-building. It highlights the tensions, contradictions and questions that remain with regard to (1) the heterogeneity of the post-return experience, (2) the complex meanings of and motivations for return migration, (3) the hierarchization of returnees' mobility and immobility and (4) returnees' room to

\footnotetext{
${ }^{1}$ Parts of this chapter and of chapter 9 appear in Van Houte, Marieke and Tine Davids. Forthcoming/a.

"Moving Back or Moving Forward? Return Migration, Development and Peace-Building". Diversities.

${ }^{2}$ See the Glossary for the definitions of migration and return migration used in this thesis.
} 
manoeuvre in their negotiation between spaces of belonging. It then discusses how this thesis addresses these issues in order to (5) interrogate the expectations on which the linkages between return migration, development and peace-building are based.

\subsubsection{From Cold War protection to return migrants as agents of change}

The end of the Cold War set in motion a number of changes in the industrialized states that led to a gradually shifting discourse, from integration to return and from viewing migrants as victims of rival regimes to seeing them as agents of change in their country of origin. The first consequence of the end of the Cold War was an increasing impatience about accommodating asylum seekers. Protecting refugees from rival regimes had been a powerful source of propaganda while the non-departure regime of the Iron Curtain countries had kept refugee levels manageable. After the end of the Cold War, the protection of refugees lost its geopolitical and ideological value for Western states. In addition, changing political and economic boundaries, growing inequality and increased civil conflicts in the post-Cold War period caused increased numbers of refugees and asylum seekers (Black and Koser 1999, Chimni 2000, Hyndman 2012, Castles, De Haas, and Miller 2014, 226).

Along with these increasing immigration flows, the notion emerged that a general increase in migration flows threatens social cohesion, welfare and security in destination countries. This resulted in growing public and political resistance towards immigration in the 1990s. The events of 11 September 2001, which linked migration to issues of security, conflict and terrorism, led to a further decrease in tolerance towards non-Western, Muslim and, or immigrant groups (Skeldon 2008, Raghuram 2009, Castles, De Haas, and Miller 2014, 226, 324). Finally, the interest in managing migration increased further in the context of the economic recession in Europe from 2008 onwards (ICMPD and ECDPM 2013).

The perceived need of host countries to contain migration led to a change from policies that were designed to welcome Cold War refugees to regimes that were meant to exclude unwanted or unproductive migrants (Chimni 2000, Blitz, Sales, and Marzano 2005, Duffield 2006, Castles, De Haas, and Miller 2014, 226, 324). Obtaining refugee status became more difficult (Koser and Black 1999, Black and Gent 2006), and the act of leaving one's home and seeking asylum was progressively criminalized (Duffield 2006). Migrants were increasingly seen as 'exploiting' refugee status rather than being in genuine need of protection from persecution (Koser and Black 1999). New legislation, such as laws setting up temporary protection regimes instead of permanent refugee status, was passed to ensure the eventual return of asylum seekers (Castles, De Haas, and Miller 2014, 226).

A second trend after the collapse of the former superpower hegemony was a discourse change towards individualization, which also appeared in the fields of migration, development and conflict. In migration policy, individualization meant that return back 'home' after conflict, to restore the natural and social order, came to be portrayed as a basic human right (Chimni 2000). Since the early 1990s, the United Nations High Commissioner for Refugees (UNHCR) and other international bodies have promoted and facilitated return as the most desirable of all solutions for refugees 
(Malkki 1992, Stein and Cuny 1994, Hammond 1999, Zetter 1999, Omata 2013). In practice, however, a strong interest in the return of unwanted migrants led host countries to put pressure on migrants and rejected asylum seekers to return much sooner than the migrants themselves found feasible, through financial inducements or the threat of deportation (Blitz, Sales, and Marzano 2005, Black and Gent 2006).

In the context of the growing significance of civil conflicts, the limited success of classic development institutions and reduced budgets for aid and defence, the discourse of individualization led to the search for alternative grassroots actors for development and peace-building (Zunzer 2004, Duffield 2006). Governments and international agencies became attracted to the idea of ascribing to migrants the moral responsibility for development and peace-building in their places of origin (De Haas 2006, Faist 2008, Skeldon 2008, Raghuram 2009). Policies aimed at stimulating the link between migration and development usually contain elements promoting remittances, skilled migration, circular migration, the engagement of diasporas and return migration (GCIM 2005, Skeldon 2008, ICMPD and ECDPM 2013).

In countries throughout the European Union, ${ }^{3}$ the return of failed asylum seekers and undocumented migrants has become an intrinsic part of migration and development policies. In the Netherlands, even the first policy note on migration and development in 1996 noted that there can be migrants who, because of their education and experience, also in the Netherlands, have the potential to contribute to the development of their countries of origin on return' (in Mommers and Velthuis 2010, 23). From this perspective, financial resources for development cooperation were made available to support the Dutch return policy (Ibid.). Today, asylum and immigration policies and so-called 'Assisted Voluntary Return' (AVR) programmes take up a substantial part, if not the bulk, of several European countries' migration and development policies and budgets. These programmes are financed with, on average, three to nine per cent of Official Development Assistance budgets (ODA) (Castles and Miller 2009, ICMPD and ECDPM 2013).

These policies on return migration and development connect three interrelated goals for migration, development and security. First, they meet the need to manage, control and regulate migration by providing a return incentive for unwanted migrants. Second, they aim to defend domestic security and the welfare of the host state by providing a safety net to avoid any destabilizing effects of return. Third, they claim to promote international development and peace-building in the country of origin. By labelling AVR as capacity building, these programmes can be paid out of ODA budgets. Other programmes that promote the link between return and development facilitate the temporary or circular return of highly skilled migrants (Faist 2008, Frouws and Grimmius 2012, ICMPD and ECDPM 2013). The overlapping goals and needs that led to policies on return migration and development are shown in Figure 1.1.

\footnotetext{
${ }^{3}$ Notably Belgium, France, the Netherlands and Spain. See ICMPD and ECDPM (2013) for an analysis of the migration and development policies of 11 European countries and of how these often include 'Assisted Voluntary Return' programmes.
} 
Figure 1.1 Return, development and peace-building goals, needs and policies
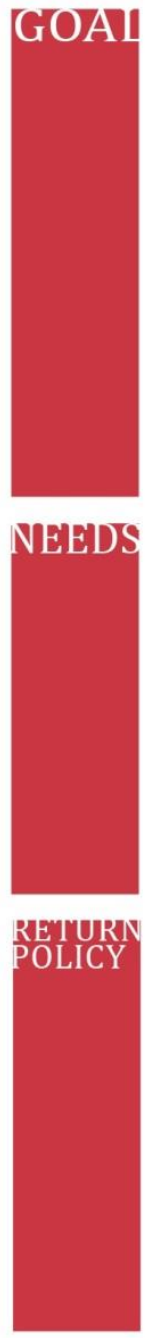

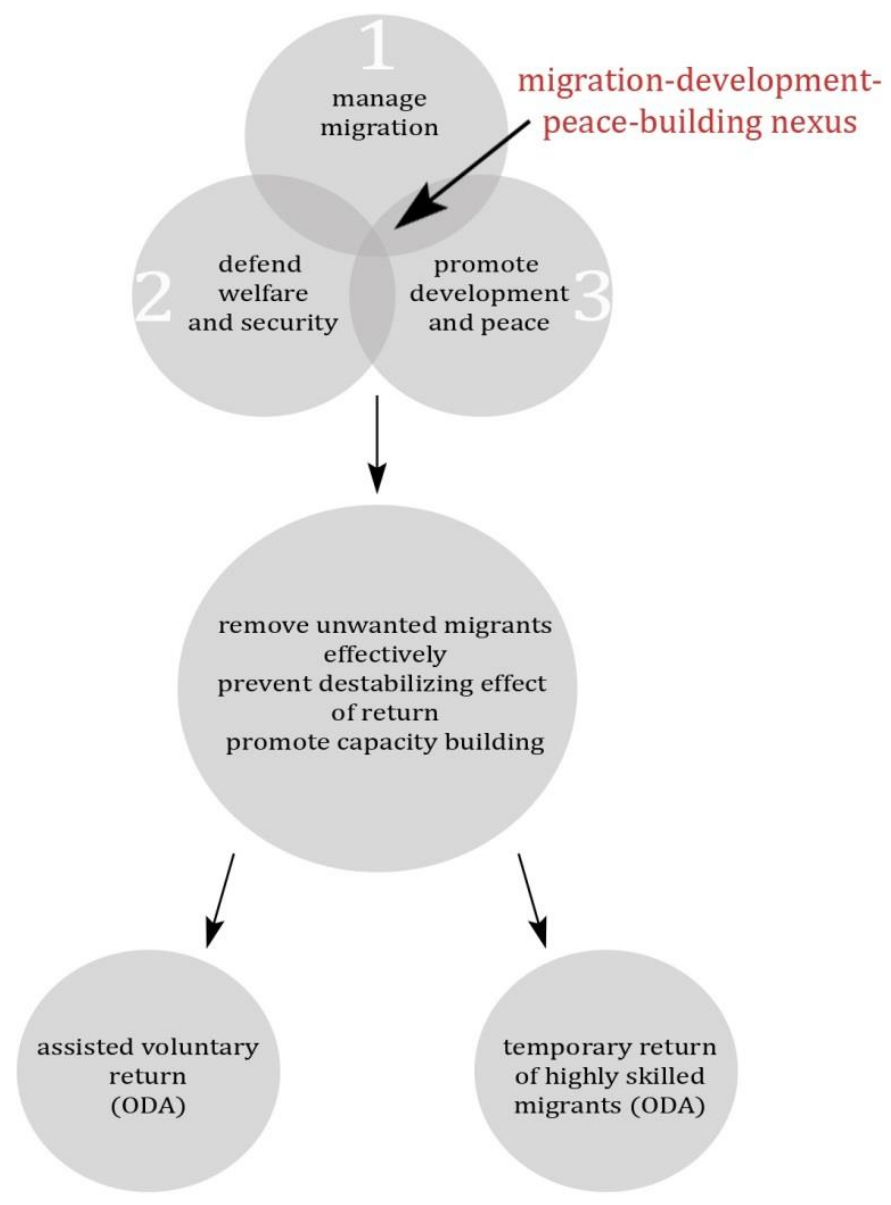

The overlapping of three goals into one migration and development policy and the practice of using ODA budgets for return programmes, although allowed by the ODA reporting system managed by the OECD, raises many questions (ICMPD and ECDPM 2013). First, the paradoxical expectations that returning migrants will both restore the pre-conflict natural and social order of their country of origin and the same time be agents of change need to be explored (Koser and Black 1999, Faist 2008). Second, there is the question of which categories of returnees are expected to contribute to what kind of change. In the next sections, I will explore these questions before introducing the research questions of this thesis that address these issues. 


\subsubsection{Return as restoring order: is return going home?}

The argument that return means the restoration of the natural and social order in the country of origin implies that, when the initial reasons for migration have disappeared, return equals going 'home' to the pre-conflict and pre-migration life (Malkki 1992). Return after conflict is seen as a means of undoing the negative consequences of conflict that were embodied in refugee flows (Black 2001, Eastmond 2006). Particularly after international military intervention, repatriating refugees is intended to demonstrate that stability was created and that the mission was successful (Blitz, Sales, and Marzano 2005). The expectation of return as going 'home' has made reintegration a key issue on the international humanitarian agenda, which envisages the disappearance of 'any observable distinctions which set returnees apart from their compatriots, particularly in terms of their socio-economic and legal status' (UNHCR 1997, 9, Özerdem and Sofizada 2006).

Despite the political and humanitarian logic, the academic debate has now moved beyond the point of seeing return as the end of the refugee cycle where everything goes back to normal. Recent studies have explored return as a much more complicated and variegated phenomenon (Stigter 2006, King and Christou 2011), showing that neither the decision to return, nor reintegration, nor belonging to the society of return, can be assumed to be 'natural'.

First, return is not necessarily the best option or a logical movement in the lives of migrants (Monsutti 2008, Omata 2013). Their decision to move is often part of dynamic and collective livelihood strategies that include security, but also political, economic, social and cultural, aspects. The financial, physical and emotional investment required for migration implies that migrants have a lot to lose if they go back, even if the conflict has ended and the country is considered safe (Zimmermann 2012). The reasons migrants do not want to return may include the presence of an unstable or unwanted political regime, an insecure economic situation, a lack of opportunities for education, family pressure to stay and cultural issues. Uncertainty about stability and political developments in the future functions as a 'hold' factor for return (Dolan 1999, Blitz, Sales, and Marzano 2005, Braakman and Schlenkhoff 2007, Jones 2011). In addition, opportunities or gains achieved in exile can be a factor that may delay (or deter) migrants' decisions to return (Zimmermann 2012).

A second line of research highlights the fact that reintegration is not evident, as the post-conflict moment is a new phase in a dynamic and ongoing process rather than a return to the pre-conflict situation (Hammond 1999, Al-Ali, Black, and Koser 2001, Cassarino 2004, Faist 2008, Sinatti 2011, Jain 2012). Instead of bringing the situation back to normal, return may increase tensions in the society of origin and hinder the transition from war to peace for different reasons. First, large-scale repatriation movements can stretch the resources in and disrupt the society of return (Özerdem and Sofizada 2006). Second, returnees may be associated with former ethnic and political (élite) structures or face challenges in restoring their livelihoods, property, documents and rights (Blitz, Sales, and Marzano 2005, Özerdem and Sofizada 2006). Third, distrust and resentment around questions of loyalty between returnees and those who stayed in the country can form a new source of conflict (Zunzer 2004, Bhugra and Becker 2005, Chan and Tran 2011). 
In addition to the socio-political and economic challenges of return, a third line of research highlights the tension between return, identity, home and belonging (Pedersen 2003). First, 'home' has changed, because the post-war economic, social, cultural and political situation in the society of origin is often very different from what it was when people left it (Ghanem 2003). Second, the notion of the homeland as a 'purified space of belonging' (Ahmed 1999, 339) no longer fits into the experience of migrants who construct multiple and hybrid forms of belonging. Migrants' identifications become more complicated with each migration movement. In addition, protracted refugee situations produce second-generation migrants who were born outside of the country of 'origin', which further complicates the notions of 'home' (Hammond 1999, Ghorashi 2003, Long and Oxfeld 2004b, Faist 2008, Monsutti 2008, Raghuram 2009, De Haas 2010). In order to reconcile the multiple aspects of their identity, returnees have to negotiate with the community of return for both distinctiveness and authenticity (Potter 2005, Christou 2006, Chan and Tran 2011).

The dynamic and multi-local notions of home and belonging challenge the conceptual understanding of return. Can migrants who return while identifying and maintaining strong ties with other places of belonging still be considered to have returned (Pedersen 2003)? Or, to put it the other way round, would non-return imply a lack of belonging to the country of origin (Koser and Black 1999)? The wealth of literature suggests that the ambiguity and variety in the notion of 'home' needs to be taken into account, in order to produce empirically and theoretically valid insights into return migration (Hammond 1999, Black and Gent 2006).

\subsubsection{Return as change: contributing to human capital and peace or perpetuating inequality and conflict?}

In contrast to the restoration of order argument, which implies the disappearance of differences between returnees and the local population, the return as change argument highlights the potential of such differences (King 1978, Bakewell 2008, 2010). First, as migration to industrialized countries is the privilege of a relatively wealthy minority, these migrants are considered to be the better-educated, wealthy, entrepreneurial and strongly-networked élite. Second, these people are expected to have acquired skills, capital and ideas while abroad. Third, they are believed to adopt an 'in-between' position between the host country and the country of origin that enables them to mediate between cultures and negotiate change (King 1978, Portes 1999, Al-Ali, Black, and Koser 2001, Sørensen, Van Hear, and Engberg-Pedersen 2002, De Haas 2005, Potter 2005, Sherrell and Hyndman 2006, Bloch 2008, Hall and Kostić 2009, Jones 2011).

Despite these specific expectations about the characteristics of return migrants that make them agents of change, a number of gaps remain insufficiently explored (Raghuram 2009). First, the increasing significance and benefits of mobility and access to transnational circuits makes inequalities with regard to the right or capacity to migrate an important dimension of social stratification, exclusion, poverty and uneven development (Bauman 1998, Portes 1999, Carling 2002, Sørensen, Van Hear, and Engberg-Pedersen 2002, Castles 2007, Faist 2008, King 2012). The increases in socio-economic differences that are caused by migration can induce conflict rather 
than contribute to stability (Zunzer 2004). The study of migrants' contribution to development should therefore recognize the hierarchization of people's rights to migrate (Castles 2005, 218, Castles, De Haas, and Miller 2014, 75-76) and 'the power geometries of transnational relations and migratory movements' (King 2012, 144).

A second knowledge gap is the limited and contradictory evidence on the extent to which migrants are willing and able to change existing structures in their country of origin. Insofar as migrants have adopted knowledge, skills, attitudes and ideas in the 'West', these new skills may not be welcomed and can even be seen as harmful by the local community (Zunzer 2004). And even if this input is evaluated positively, how can individuals negotiate change in the society of return (Faist 2008)? Does their 'inbetween' position make them independent enough to overcome the constraints of structures of which they themselves form part (Portes 1999, Sørensen, Van Hear, and Engberg-Pedersen 2002, Wijers 2013)? Or, alternatively, is change only possible within an enabling institutional and economic framework (Ammassari 2004, Castles, De Haas, and Miller 2014, 78)?

Third, migration-development-peace-building policies not only assume the ability of migrants to contribute to change in often complex 'post-conflict' areas, but also have specific, yet under-defined, expectations of the type and direction of such change (Bakewell 2008, Faist 2008, Raghuram 2009). Implicitly, the notion of change is tied to socio-economic modernization, in which migrants introduce innovation, a sense of progress, justice, democracy and human rights into the society of return (King 1978, Raghuram 2009). In addition, change is expected to take place within existing (political) frameworks. Independence movements, power shifts, political unrest, religious-based opposition and illegal activities are not the kind of change for which policy makers are hoping. Particularly since the events of 11 September 2001 and the start of the 'War on Terror', and with the recent developments of young Muslims travelling from Europe to Syria and Iraq to join Jihad movements, there is a heightened awareness that migrants may also contribute to the 'wrong' kind of change (Raghuram 2009, Castles, De Haas, and Miller 2014, 79). The idea that migrants' actions can and should be steered however raises questions (Raghuram 2009).

\subsubsection{What kind of returnees? Meanings of and motivations for mobility}

The tension between return as a movement back to normal and return as a movement forward to change touches upon more fundamental questions about the meaning of mobility in the lives of migrants. The perception of return as 'going back to normal' conceptualizes mobility as a disruption of life, migrants as victims of this disruption and return as the restoration of a normal, sedentary life (Bakewell 2008). By contrast, the perception of return as change comes from the expectation that migrants increasingly benefit from their 'hyperglobal' (Carling 2002) and 'hypermobile' (King 2012) lives, in which they may become detached from place (Hess 2004, Long and Oxfeld 2004a, Castles 2007, Nagel and Staeheli 2004, King and Christou 2011, Levitt, Lucken, and Barnett 2011).

Although this understanding of migrants as either victims or agents informs the dichotomies between voluntary and forced migration, the reality is more complex and heterogeneous (Carling 2002, Tsuda 2004, King 2012). Scholars highlight the fact that 
the motivations and meanings of migration and return are the outcome of a complex mix of migrants' choices and constraints on staying or moving (King 1978, Stein and Cuny 1994, Al-Ali, Black, and Koser 2001, Cassarino 2004, Bakewell 2008, Bloch 2008, Monsutti 2008, Zimmermann 2012). Migration can be considered as a livelihood strategy through which people can adapt to constantly changing circumstances (Monsutti 2008). It is argued that even wartime migration, although associated with disruption and loss, is less disempowering than involuntary immobility (Carling 2002, Lubkemann 2008). Overseas migrants, although not all part of the élite, are usually not among the poorest people in their countries of origin (Faist 2008, De Haas 2010).

With regard to return, it is argued that the motivation for return defines an important part of the post-return experience (Cassarino 2004). Cerase (1974) argued that migrants who return because of failure will be reabsorbed into society as if they had never migrated, while successful migrants who return with the ambition to start a new life could potentially be a source of innovation. Although recent studies show a more nuanced position, going beyond the dichotomies of success and failure and taking into account a wider variety of migrants, they recognize similar processes. For example, Cassarino developed a model for studying return, distinguishing between the willingness and the readiness that together create the preparedness to return (Cassarino 2004, 2014).

Several authors argue that legal status is an important factor that shapes the meanings of and motivations for migrants' return (Al-Ali, Black, and Koser 2001, Bloch 2008, Brees 2010). First, legal status makes access to industrialized countries a scarce resource (Carling 2004). While people with a secure status can easily leave the host country, as they have the confidence that return is possible if things do not work out, those without legal status are more reluctant to leave, as it is both costly and risky to re-emigrate (Carling 2004, Blitz, Sales, and Marzano 2005, Jones 2011). Second, migrants who do not have legal status may not return if they are unable to accumulate sufficient possessions for a secure and successful life as a result of economic and social vulnerability (Dolan 1999). For these reasons, it is argued that return cannot be voluntary when there is no plausible (legal) alternative (Noll 1999, UNHCR 2009), and that such return represents instead a strategic choice to avoid forced removal (Black and Gent 2006).

\subsubsection{The need for a broader perspective}

Although current policies suggest an inherent and positive link between return migration, development and peace-building, academic contributions to the discussion show that there is limited and contradictory empirical evidence on the nature, quality and direction of this link (King 1978, Ammassari 2004, Skeldon 2008, Raghuram 2009, ICMPD and ECDPM 2013, Castles, De Haas, and Miller 2014, 75-77). Several authors argue that returnees can be both an opportunity, bringing prosperity to the country of return, and a social problem, leading to a 'spiral of decline', through inducing conflict, inequality or economic hardship (Koser and Van Hear 2003, Carling 2004, Black and Gent 2006, Mohamoud 2006). While under current migration and development policies, failed asylum seekers have been implicitly considered to be equal to successful migrants, migrants include a very heterogeneous mix of people 
who have a diverse set of skills, networks, assets and motivations (Koser and Van Hear 2003, Cassarino 2004, 2014). In addition, the opportunities they have in destination countries may vary strongly, affecting their behaviour (see for example Ghorashi 2001, Oeppen 2009). Their potential upon return can therefore be expected to be equally variable, influencing processes of peace-building and development in the country of origin in both positive and negative ways (Cassarino 2004).

The paradox of current return migration and development policies lies in the fact that they are based on the expectation that return migration is both a movement back to normal and a movement forward to change, although these two concepts remain under-defined. In addition, the question is why and how return migrants should contribute to development, when official aid programmes have failed (Castles and Miller 2009, 58). Questions are raised as to why European governments target the migrants on their territories, who are a minority of all migrants, as instruments for development in their countries of origin (Skeldon 2008, Raghuram 2009, ICMPD and ECDPM 2013).

Scholars argue that programmes that stimulate the migration-developmentpeace-building nexus are more heavily motivated by the host countries' interests in managing and controlling migration movements than by the goal of development in the countries of origin (Zimmermann 2012, ICMPD and ECDPM 2013, Castles, De Haas, and Miller 2014). It is argued that AVR programmes come from the realization by governments that these programmes are less costly and politically less painful than enforced removal (Stein and Cuny 1994, Blitz, Sales, and Marzano 2005, Black and Gent 2006). Other scholars express their concern about 'the systematic erosion of the principles of protection and the rights of refugees' (Chimni 2000, 251).

Several authors argue that policy makers consider migration as a functional tool that can be 'turned on and off like a tap' through laws and policies (Castles 2007, 363). Policy makers tend to think in dichotomies that become bureaucratic categories, meant to serve political purposes and the need to define measurable policy goals (AlAli, Black, and Koser 2001, Zimmermann 2012). In today's globalized context, however, dichotomies and generalizations based on 'home' and 'origin' countries, 'forced' and 'voluntary' mobility and temporary or permanent return do not reflect the reality and complexity of migrants' experience (Pedersen 2003, De Haas 2005, Bakewell 2008, Faist 2008, Monsutti 2008, Schuster 2011, Zimmermann 2012).

Without theoretical and empirical foundation, the discussion on the relationship between migration, development and peace-building risks being reduced to a merely political and ideological issue that congeals into normative frames (Raghuram 2009) and produces inadequate policies (Bakewell 2008). Scholars highlight the need for theoretical approaches that are more encompassing, and for analytical tools that address the complexity and heterogeneity of return, development and peace-building (Cassarino 2004, Stigter 2006, Castles 2007, Bakewell 2010, De Haas 2010). The next section shows how this thesis addresses these issues. 


\subsection{Research question}

This thesis takes a transnational and multidimensional approach in order to overcome the dichotomies, generalizations and empirical shortcomings that surround the understanding of return migration within the migration-development-peace-building nexus. It uses the concept of multidimensional embeddedness, which provides an encompassing perspective on returnees' identification with and participation in one or multiple spaces of belonging. It explores (1) the heterogeneity of the post-return experience, (2) the complex meanings of and motivations for return migration, (3) the hierarchization of returnees' mobility or immobility and (4) returnees' room to manoeuvre in their negotiations between spaces of belonging, in order to (5) interrogate the expectations on which the link between return migration, development and peace-building is based. The thesis answers the following main question:

Under what circumstances are migrants returning from industrialized countries willing and able to contribute to change with regard to development and peace-building in their 'post-conflict' country of origin?

The complex, multifaceted nature of contemporary migration processes requires an interdisciplinary approach (Massey et al. 1993, Castles, De Haas, and Miller 2014, 27). Trained in cultural anthropology and development studies and writing this PhD thesis at a policy-oriented institute, I approach the question of the development potential of return migrants through an anthropological lens, in a critical interrogation of the assumptions that inform host governments' migration policies (Zimmermann 2012).

The study takes a comparative and in-depth approach, focusing on the experiences throughout the life courses of return migrants while building on two methodologically complementary research phases. The first phase is a comparative mixed methods study among 178 returned rejected asylum seekers and undocumented migrants in six countries across the world that explores general trends in the field of return migration, asking the following research question:

1. What factors determine the post-return multidimensional embeddedness of migrants returning from industrialized countries to six 'post-conflict' countries across the world?

The second phase builds on and complements this comparative work with an in-depth case study among 35 voluntary and involuntary return migrants in Afghanistan, addressing the complexities of return migration with the following questions:

2. How can the complex meanings of and motivations for return of (Afghan) migrants from Europe be analysed?

3. How does the migration experience affect post-return embeddedness and socioeconomic inequality among Afghan migrants returning from Europe?

4. How do Afghan migrants returning from Europe negotiate their belonging to multiple spaces of embeddedness (through expressions of marriage, sexuality and gender)? 
5. How do Afghan migrants returning from Europe identify with the conflict, and what is their potential to contribute to change in processes of development and peace-building in their country of origin?

Throughout this thesis, I will interrogate and explore the conceptual understandings of return migration, development, peace-building and voluntary or involuntary migration. These concepts will therefore not be further operationalized here. In addition, 'post-conflict' is a complicated term. Although it is often used to identify a country where a war or crisis has ended, the underlying conflict often remains unresolved. In this thesis, 'post-conflict' is put within inverted commas to recognize the ambivalence of this terminology versus reality. Next, a brief historical review of the theoretical perspectives on migration, return and development explains the choice of transnationalism and embeddedness as a conceptual approach for this study. Thereafter, an outline of this thesis shows how I address the research questions and how they are interrelated.

\subsection{Theoretical perspectives on return and development}

Structure, agency, or structure and agency?

Migration and return occur according to observable (but shifting) patterns across space and time (Castles 2007, Bakewell 2010). Over time, different theoretical paradigms and approaches have led to shifting understandings of these patterns of migration and return. Since the emergence of migration as a systematic area of study, the link with development has been an integral part of these studies, informing migration policies (Skeldon 2008, Castles, De Haas, and Miller 2014, 46-47). These theoretical paradigms have developed around shifting perceptions of the role of structure and agency. Structures can be defined as the constraining or enabling forces in the political, institutional, economic, social and cultural context that are external to and have an impact on people. Agency can be defined as the self-perceived control individuals have over their actions, and the choice they have to stay within, to overcome or to reshape structures (Sewell 1992, Hitlin and Elder 2007, De Haas 2010). Chapter 5 elaborates further on the discussion of agency and structure. Each successive paradigm shift provided new insights, leading to an increasingly complex understanding of the link between migration and development. A very brief overview helps to understand how current approaches build on previous insights.

\subsubsection{Neoclassical approach \\ Optimistic views based on individual agency}

The earliest systematic theories on migration emerged in the late nineteenth century from a neoclassical approach. Neoclassical theories emphasize migration as an individual decision for income maximization in the context of geographic differences in the supply of and demand for labour. Potential migrants are seen as utility maximizing market players, who have perfect knowledge of economic factors such as wage levels and employment opportunities, allowing them to make rational choices, 
based on push and pull factors and the costs and benefits of migration (Massey et al. 1993, Cassarino 2004, Skeldon 2008, De Haas 2010, Castles, De Haas, and Miller 2014, 28-30).

The link between migration and development was studied from the 1960s onwards. Migration was argued to set in motion natural equilibrium-restoring mechanisms between low-wage and high-wage countries through financial remittances and the transfer of human capital after return migration (Faist 2008). Mirroring the flow of workers from labour-abundant to labour-scarce countries is a flow of investment capital from capital-rich to capital-poor countries (Massey et al. 1993). In this framework, return migrants were seen as important agents of change and innovation. It was expected that migrants would bring back not only money, but also new ideas, knowledge, and entrepreneurial attitudes. In this way, migrants were expected to play a positive role in development and contribute to the accelerated spatial diffusion of modernization in developing countries (De Haas 2010).

The limitation of the neoclassical push-pull model, with its emphasis on the atomistic utility maximizing individual, is that it does not sufficiently explain why relatively few people migrate, why migrants move to one country rather than another, and why some migrants end up in deprived situations. While the theory suggests that the poorest people from the least developed countries would move to the richest countries or from densely to sparsely populated areas, the opposite is the case in reality. This shortcoming comes from a failure to take into account structural constraints on people's actions and the fact that migrants' behaviour is influenced by historical experiences as well as by their belonging to social groups (Carling 2002, De Haas 2010, Castles, De Haas, and Miller 2014, 31).

\subsubsection{Structuralism \\ Pessimistic views based on structural constraints}

While neoclassical approaches looked at individual decisions on the supply side of migration, a paradigm shift in the late 1960s towards historical-structuralist approaches provided an alternative explanation for international migration. The organization of migration and return became seen as the interaction between migrants' expectations, on the one hand, and structures such as access to employment, markets, education and power, on the other (Cassarino 2004, Castles, De Haas, and Miller 2014, 32). It was increasingly understood that return happens in a variety of circumstances and for a diversity of reasons, which can encompass both success and failure (Cerase 1974, Cassarino 2004, Gmelch 1980).

The realization that structural constraints severely limit people's ability to overcome poverty and general underdevelopment challenged earlier optimistic views that migration alone would enable people to overcome these structures and to appear as actors of change (De Haas 2010). Structuralist approaches argue that, rather than bringing in change, returnees are forced to readjust to local economies, power relations, traditions and values (Cerase 1974, Cassarino 2004). In addition, the structuralist approach highlights the fact that migration causes a brain drain and increases inequalities, since migration itself is a privilege of those who are better off, and it are mostly their relatives who will benefit from it (Faist 2008, De Haas 2010). 
Like the neoclassical approach, the historical-structuralist perspective on migration was criticized as being too one-sided. While neo-classical perspectives on migration and development tend to underestimate structure, structuralist perspectives overestimate the importance of structural constraints and thereby largely rule out agency. In shifting the emphasis from agency to structure, these approaches complement the neoclassical theories, but yield just as little insight (Carling 2002, Castles, De Haas, and Miller 2014, 36). This focus on structural limits and constraints, especially with regard to migration from conflict-affected countries, was criticized for its rigid causal determinism and self-affirming nature. It was argued that these theories do not leave much room for heterogeneity and human agency and are unable to explain change (Sewell 1992, Bakewell 2008, De Haas 2010).

\subsubsection{Post-structuralism \\ Agency and structure combined}

From the 1980s onwards, a paradigm shift caused contemporary social theory to move away from deterministic theoretical schemes predicting the development outcome of migration towards more hybrid approaches that fitted within the tendency of individualization (Faist 2008). Social scientists were influenced by postmodernist thinking, which sought to harmonize agency and structure-oriented approaches. Giddens' (1984, 1991 in Sewell 1992) structuration theory examines the dialectic interplay between agency and structure, and proposes that structures, rather than only affecting individuals' agency, are both the medium and the outcome of social systems. This development led to post-structuralist, pluralist and post-nationalist discourses with a renewed emphasis on agency, which continues to be the dominant paradigm today. In this light, migration has increasingly been seen as a dynamic process (Bakewell 2010, King 2012, Castles, De Haas, and Miller 2014, 37).

Most empirical work from the late 1980s and the 1990s also acknowledged the heterogeneous, non-deterministic nature of migration-development interactions (De Haas 2010). The renewed emphasis on agency led to more optimistic expectations of the influence of individual migrants on processes of social transformation. Migrants are not victims of the structures in which they are embedded, even though mobility is always more or less constrained (Hyndman 2012), 'some are more in charge of it [mobility] than others' (Massey 1993, 62), and 'vast swathes of the world's people are not as free to move as they would like' (King 2012,136).

A satisfactory post-structuralist theory must take into account both the structural forces that promote or constrain migration and the motivations, goals and aspirations of the people who migrate (Bakewell 2010). In addition, since the experience of migration embraces every dimension of human existence, a multidisciplinary perspective is needed. Lastly, post-structuralist theory should take into account the complexity, contradictions and unintended consequences of social action, while not becoming too abstract (Castles 2007).

\section{Transnationalism: Post-structuralism in a globalized world}

The post-structuralist movement coincided with a process of globalization that has 'increased the ability of migrants to maintain network ties over long distances' 
(Castles, De Haas, and Miller 2014, 41). People find themselves integrated into larger economic, cultural and political systems (Eriksen 1995) in which high degrees of mobility, circularity and connectivity are key aspects (Eriksen 1995, 312-313, Appadurai 2010, Castles, De Haas, and Miller 2014, 41). Technological revolutions such as the (mobile) telephone and the internet have expanded the opportunities for migrants to remit money and foster links with their societies of origin on a more constant, day-to-day basis, and increased their benefit in doing so (Carling 2002, De Haas 2010).

In this context of globalization, the post-structuralist paradigm led in the 1990s to the emergence of transnationalism. This has arguably been the dominant discourse in migration research over the past two decades (King 2012). Transnationalism can be defined as the process by which migrants develop and sustain multi-stranded ties, relationships and exchanges - familial, economic, social, religious and political - that span borders and link their societies of origin and their societies of settlement (Basch, Schiller, and Szanton Blanc 1994, Portes 1999, Castles 2007). Social life becomes detached from its local, spatially fixed context and instead takes place in subnational spaces and deterritorialized communities (Eriksen 1995, 312, Al-Ali, Black, and Koser 2001, Oeppen 2009).

The transnational social space increasingly enables migrants and their families to pursue transnational livelihoods and connect simultaneously to multiple and distant places, through their social relations, employment and expressions of identity (Vertovec 1999, Guarnizo, Portes, and Haller 2003, De Haas 2010). Transnational interactions and encounters include all concrete cross-border exchanges, such as remittances, visits, transnational business activities, investments, political involvement, phone calls and e-mails. In addition, transnationalism comprises less tangible issues, such as memories and ideas about home and belonging (Al-Ali, Black, and Koser 2001, Vertovec 2001, King and Christou 2010, Bailey 2012, Erdal 2012).

Transnationalism questions the assimilationist notion that integration in the host country and engagement in the country of origin are mutually exclusive (De Haas 2005, Snel, Engbersen, and Leerkes 2006, Oeppen 2009). Rather than uprooting their social life and planting it in a new country, migrants expand their social environment across borders (Basch, Schiller, and Szanton Blanc 1994, Smith and Guarnizo 1998, Portes 1999, Cassarino 2004). These simultaneous attachments in the country of origin and the country of settlement, and possibly in other places, lead to 'double' (Mazzucato 2008) or 'simultaneous' (Levitt and Schiller 2004) engagements and 'inbetween', hybrid identities (Ahmed 1999, Ghorashi 2003, King and Christou 2010).

The transnational turn has led to a remarkable turnaround and a renewed optimism about the link between migration and development, with more ability to change structures being attributed to migrants (De Haas 2006, 75, Skeldon 2008, Castles, De Haas, and Miller 2014, 73). First, transnational engagements and migration show the ability of individuals and households to overcome structural development constraints by taking advantage of geographical differences in a deliberate attempt to diversify, secure and improve their livelihoods (Gardner and Grillo 2002, Faist 2008, De Haas 2010).

Second, migrants' continued multiple engagements have had various development implications. If migrants' engagement with their origin countries is not conditional on their return, the departure of migrants does not automatically 
represent a loss in the form of a brain drain, as their 'brains' can continue to play a role through remitting money and ideas (De Haas 2010). In addition, continued transnational ties and transnational mobility could support coping mechanisms and reduce vulnerabilities (Cassarino 2004, Stigter 2006). Last, the multi-local ties they maintain also lead to negotiation on social order, transformation and hybridity (Amelina 2010). In the debate on migration and development, this led to the expectation that migrants can be mediators between cultures, who can combine identifications within modern ideas, norms and values with feelings of belonging to the country of origin, and that this gives them the opportunity to transfer knowledge and skills (Potter 2005, Jones 2011).

Although the transnational approach offers clear benefits for studying the complexity of migration, it also comes with a number of challenges. First, although transnationalism challenges the position of the nation state and 'methodological nationalism' (see chapter 2), the nation state cannot easily be treated as irrelevant. Assimilation into nation states continues to be an underlying principle in political and public debates about migration. In fact, globalization has increased the feeling among many sections of the population in destination countries that migration is a direct threat to their livelihood, social conditions and identity that should be 'solved' through restrictive immigration policies (Wimmer and Schiller 2003, De Haas 2010, Castles, De Haas, and Miller 2014, 315). In addition, the nation state continues to be an important site of belonging and rootedness for migrants (Tsuda 2004).

A second challenge of transnationalism is that, while it has provided an encompassing solution for studying migrants' complex realities, there is also an argument that it is surrounded by theoretical ambiguity and analytical confusion (Guarnizo, Portes, and Haller 2003). While the globalized and transnational approach assumes that place and distance are becoming less important, migrants, although often on the move, are not 'in the air' (Ley 2004, Erdal 2012) and their movement between places is intrinsically geographical (King 2012). Authors criticize the vagueness of transnational, 'hyperglobalist' terminology (Carling 2002, 7-8), which has been subject to different interpretations that have generated sloppiness in its usage and analytical relevance (Cassarino 2004). The concept of embeddedness, which I discuss below, is a transnational and multidimensional approach that addresses this need for an encompassing perspective, while preventing vagueness.

\subsubsection{Embeddedness \\ A multidimensional approach to studying transnational realities}

Embeddedness is defined here as the process of an individual's identification with and participation in one or multiple spaces of belonging. The concept encompasses the above-mentioned characteristics and challenges of transnationalism and highlights the duality between agency and structure. It has been identified as being useful for the study of migration. Nevertheless, Portes and Sensenbrenner (1993) also point out the theoretical vagueness that surrounds the concept. Therefore, one of the aims of this thesis is to provide a clear understanding of the concept and, where possible, to contribute to its empirical applicability. The concept will be further explored in the 
next chapters, but here I will highlight some of its benefits with regard to the discussion above.

First, the encompassing and multi-local approach of embeddedness can incorporate understandings of integration and transnationalism, and mobility and immobility, within one concept. This helps in studying the 'simultaneous' or 'double' engagements of migrants as complements rather than substitutes. In addition, since embeddedness is not exclusively about migration, the concept can be used to compare migrants and non-migrants.

Second, the relational aspect of embeddedness stresses that human behaviour, including migration, is not an isolated process, but is the result of the interaction between individuals and their social environment (Kloosterman, Van Der Leun, and Rath 1999, Van Liempt 2011). Human beings are seen as pro-active, intentional agents who influence and are influenced by the social worlds in which they are located. This creates room for the integration of identity as a complex process in which notions of self, other, home, place and culture are fluid, dialogically constructed and intimately tied to migration (Li et al. 1995, Findlay and Li 1997, Pedersen 2003, Buitelaar 2006, Erdal 2012).

Third, the multidimensional aspect of embeddedness highlights the interplay between social, cultural, economic and institutional aspects, and the notion that migrants may selectively engage in or retreat from these different dimensions. In any particular space of embeddedness, migrants may be embedded strongly in one dimension and less strongly in the other (Jones 2011, Oeppen 2009, De Haas 2010, Levitt, Lucken, and Barnett 2011), leading to a splitting of 'home' as an everyday experience (Ahmed 1999).

Last, rather than measuring the intention to stay or migrate, recognizing people's embeddedness in society is the key to understanding peoples' decision-making processes in their migration and return, and the diversity in migration patterns and dynamics (Tsuda 1999, Wissink, Düvell, and van Eerdewijk 2013).

\subsection{Outline of thesis}

The following chapters are subsequent steps that lead towards an answer to the main question. Table 1.1 shows an overview of the thematic, regional, conceptual and methodological focus of each chapter. Chapter 2 elaborates on the methodological considerations, practical organization and challenges of this study. It introduces two methodologically complementary research phases, which combine a comparative mixed methods study among 178 returnees to six countries across the world with an in-depth case study of 35 Afghan return migrants. Chapter 4 explains the choice of Afghanistan as a relevant case study and sketches Afghanistan's long, large-scale and diverse history of migration patterns of which migration to and return from Europe is only a small part. Chapters 3 and 5 to 8 each address one of the sub-questions of this thesis. Lastly, chapter 9 provides a conclusion, summarizing the main findings and highlighting the contribution of the thesis to the academic debate, and the policy implications arising from it. 
Table 1.1 Thematic, conceptual, methodological and regional focus of each chapter

\begin{tabular}{|c|c|c|c|c|}
\hline $\mathrm{Ch}$ & Theme & Key words & Methodology & Region \\
\hline 2 & Methodology & $\begin{array}{l}\text { Survey; life histories; } \\
\text { participatory techniques; } \\
\text { discourse analysis; } \\
\text { challenges }\end{array}$ & $\begin{array}{l}\text { Literature } \\
\text { review }\end{array}$ & - \\
\hline 3 & $\begin{array}{l}\text { Determinants } \\
\text { of post-return } \\
\text { embeddedness }\end{array}$ & $\begin{array}{l}\text { Embeddedness; } \\
\text { return assistance; } \\
\text { personal characteristics; } \\
\text { migration cycle }\end{array}$ & $\begin{array}{l}\text { Comparative } \\
\text { quantitative } \\
\text { \& qualitative }\end{array}$ & $\begin{array}{l}\text { Afghanistan, Armenia, } \\
\text { Bosnia and } \\
\text { Herzegovina, Sierra } \\
\text { Leone, Togo, Vietnam }\end{array}$ \\
\hline 4 & Afghanistan & $\begin{array}{l}\text { History of migration; } \\
\text { conflict; return; migration } \\
\text { to Europe }\end{array}$ & $\begin{array}{l}\text { Literature } \\
\text { review }\end{array}$ & Afghanistan \\
\hline 5 & $\begin{array}{l}\text { Meanings of } \\
\text { and } \\
\text { motivations for } \\
\text { return }\end{array}$ & $\begin{array}{l}\text { Structure; agency; desires; } \\
\text { capacities; } \\
\text { voluntary vs involuntary } \\
\text { return; mobility }\end{array}$ & $\begin{array}{l}\text { In-depth } \\
\text { qualitative }\end{array}$ & Afghanistan \\
\hline 6 & $\begin{array}{l}\text { Return and } \\
\text { socio-economic } \\
\text { inequality }\end{array}$ & $\begin{array}{l}\text { Multidimensional and } \\
\text { multi-local } \\
\text { embeddedness; mobility }\end{array}$ & $\begin{array}{l}\text { In-depth } \\
\text { qualitative }\end{array}$ & Afghanistan \\
\hline 7 & $\begin{array}{l}\text { Return and } \\
\text { identity; } \\
\text { marriage and } \\
\text { sexuality }\end{array}$ & $\begin{array}{l}\text { Identity; } \\
\text { 'in-betweenness'; } \\
\text { negotiation }\end{array}$ & $\begin{array}{l}\text { In-depth } \\
\text { qualitative }\end{array}$ & Afghanistan \\
\hline 8 & $\begin{array}{l}\text { Returnees as } \\
\text { agents of } \\
\text { change }\end{array}$ & $\begin{array}{l}\text { Conflict; change; } \\
\text { development }\end{array}$ & $\begin{array}{l}\text { In-depth } \\
\text { qualitative }\end{array}$ & Afghanistan \\
\hline 9 & Conclusion & $\begin{array}{l}\text { Main findings; } \\
\text { contribution; policy } \\
\text { recommendations }\end{array}$ & $\begin{array}{l}\text { Synthesis of } \\
\text { the above }\end{array}$ & - \\
\hline
\end{tabular}

The empirical chapters are based on articles that have been published or are currently under review in scientific journals. While this thesis can be read as a book in which each chapter builds on the one before in order to answer the main question, the chapters can also be read as autonomous articles. Although this causes some overlap between the chapters, it also improves readability and makes it possible for the reader to select a chapter of interest. The organization of the empirical chapters and the way in which they fit together is displayed in Figure 1.2. 


\section{Figure 1.2 Organization of thesis}

\section{MAIN QUESTION: RETURN MIGRANTS, DEVELOPMENT AND PEACE BUILDING}

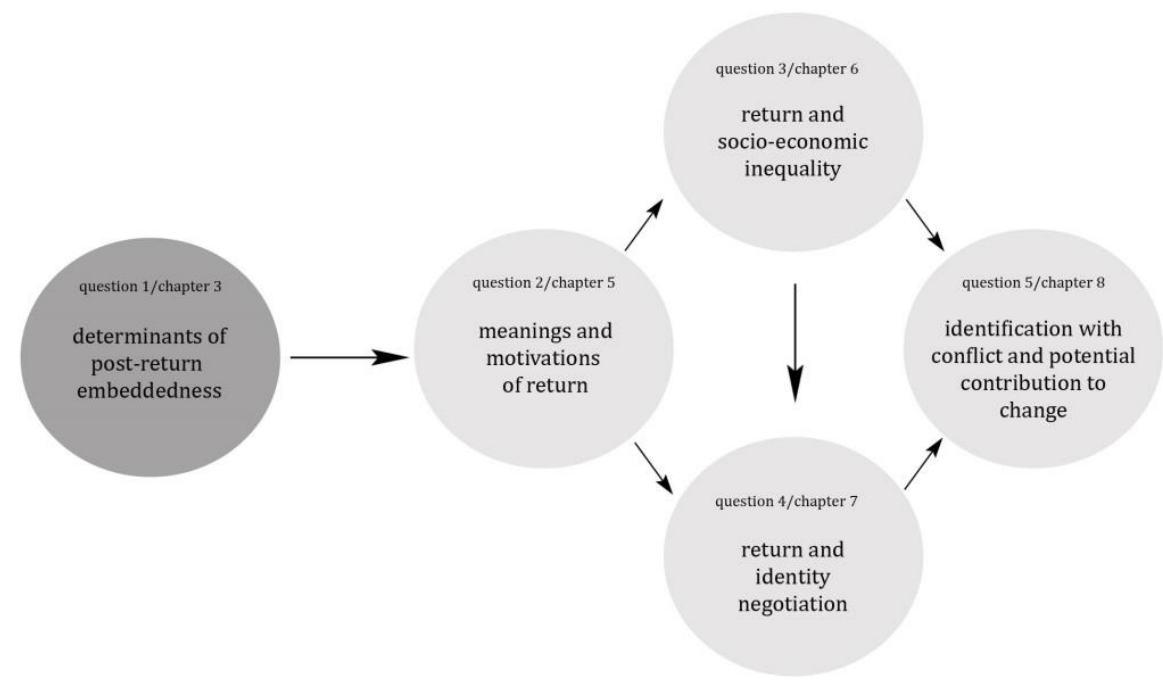

Chapter 3 investigates whether the use of ODA for AVR programmes for rejected asylum seekers and undocumented migrants is justified. It offers a comparative mixed methods approach to the experience of returnees to six countries across the world (Togo, Sierra Leone, Armenia, Bosnia and Herzegovina, Afghanistan and Vietnam). It highlights the fact that return is much more complex than going 'home' or 'reintegration'. It shows context-specific factors as well as remarkably strong general trends with regard to the factors influencing post-return embeddedness in the six very different countries of return. While showing a limited or even negative effect of return assistance, the results highlight the significance of the experiences in the migration cycle, in particular the return motivation.

Since chapter 3 highlights the importance of return motivation for post-return embeddedness, chapter 5 proposes an analytical framework for investigating the complex meanings of and motivations for migration and return. The chapter shows the use of the narrative as a valuable empirically-grounded research methodology for studying the complexity of migration. I deconstruct the policy-oriented dichotomy between voluntary and involuntary return and plead for the complexities of return to be taken into account. In addition, I propose to centralize post-return mobility, an essential desire and capacity in the lives of return migrants that strongly affects the post-return experience, as an indicator for voluntary or involuntary return.

In chapters 6 and 7 I interrogate the expectations about the characteristics of return migrants that inform the debate on the linkages between migration, development and peace-building. Chapter 6 explores a new avenue of the hierarchization of mobility: the social stratification among voluntary and involuntary 
return migrants. I argue that socio-economic differences that existed prior to migration are reinforced by the migration experience, and that this results in strongly differentiated patterns of multidimensional embeddedness and transnational mobility.

Chapter 7 focuses on the 'human dynamics' of return. It explores how Afghan migrants returning from European countries negotiate belonging to one or multiple spaces of embeddedness through their expressions and practices with regard to marriage, sexuality and gender norms. I find that when migrants are more strongly embedded in multiple spaces of belonging and are transnationally mobile, they can display more agency to apply creative responses in their personal lives. However, it is much more difficult to mediate between cultures or negotiate change in these structures. Chapters 6 and 7 both find that expectations of the development potential of return migrants are overstated and that the development potential of voluntary and involuntary returnees is very different.

Chapter 8 builds on the insights of the previous chapters to interrogate the expectation in the political and academic debate that return migrants can be agents of change for development and peace-building in their country of origin. The chapter explores four ways in which returnees relate to the conflict become apparent: physically, institutionally, psychologically and with regard to the future. It finds that the only returnees who could potentially live up to any of the expectations raised in the debate on the linkages between migration, development and peace-building are voluntary returnees. By contrast, involuntary returnees have no potential for Afghan peace-building and development. The findings highlight, first, the importance of the human dimension of returnees' involvement in the country of origin. Second, they show that transnational mobility is migrants' strongest asset for overcoming constraints and carefully negotiating change, rather than a weakness that implies their fluid commitment.

Finally, the conclusion in chapter 9 highlights that while the expectations on which migration and development policies are based, only count for a small minority of returnees, this is not the group that is targeted by policy and budgets, and that contemporary policy is responding inadequately to complex migration issues.

\subsection{Conclusion}

This chapter introduced the debate on the linkages between return migration, development and peace-building. It highlighted the tensions, contradictions and questions that remain in trying to understand the complexity of the experience of return, the meanings of and motivations for return, the hierarchization of returnees' mobility and immobility and their room to manoeuvre between spaces of belonging. This thesis will empirically explore these questions in order to interrogate the expectations on which the link between return migration, development and peacebuilding is based. Next, in chapter 2, the methodological considerations, practical organization and challenges of the study will be discussed. 
How could I put everything down on paper? It seemed impossible. No matter what, the majority of life would be left out of this story, this sliver of a version of the life I'd known.

Dave Eggers - What is the What, p. 485. 


\section{2 \\ Methodology}

A focus on the life course of migrants

\section{$2.1 \quad$ Introduction}

Migration and refugee flows are highly political themes. In order to reduce the risk of being misinterpreted, migration research needs to meet academic standards, with (1) clear and relevant concepts and (2) data that are collected in a transparent, careful and ethical way, using (3) methods that meet the complex reality of migrants (Jacobsen and Landau 2003). Two methodological points of departure inform the design of this study: the need to avoid methodological nationalism and the need for research that is both relevant to policy and gives space to the complexity of migration. I will briefly introduce these points of departure before elaborating on the two phases of research on which this thesis is based.

First, although migrants are characterized by their mobility, research on migration has often tried to 'fix' migrants analytically in space and time. The tendency to study migrants within the borders of the nation state has been called 'methodological nationalism' (Castles 2007, King 2012). In the age of globalization and transnationalism, there is a need for research methodologies that are able to address the socio-spatial ambivalence of migrants and take into account the renewed attention to human agency in migration (Castles 2003, Carling 2004, Castles 2007, Amelina 2010, King 2012). One approach to avoid methodological nationalism and give space to the multi-sited experience of migrants that transcends borders is to focus on people's life course rather than on their spatial or temporal location (Mazzucato and Schans 2011, King 2012, Meeus 2012).

Second, meaningful research on migration must negotiate between the need to inform policy and the need to understand the complexity of migration. Policy-oriented research often leads to empirical research that is too narrowly focused and 'accepts the problem definitions built into its terms of reference and does not look for more fundamental causes, or for more challenging solutions' (Castles 2003). In order to address policy-oriented issues of migration, there is a need for a broader and more thorough understanding of the abundance, richness and diversity of the migration experience (Castles 2007, Bakewell 2010, King 2012). However, transnational approaches aimed at highlighting this complexity face the challenge of producing concepts and data that are too abstract (Vertovec 1999).

Several authors therefore argue for in-depth and comparative empirical studies of transnational human mobility' (Vertovec 1999, 456, emphasis added, Castles 2003). Comparative and quantitative methods can show the distribution of trends and relationships between social objects (Castles 2007, Bakewell 2010, Kloosterman 2010). To complement this, qualitative, ethnographic and participatory methods can 
grasp the abstract mechanisms, strategies and meanings that individual migrants ascribe to their migration using their own terms (Carling 2004, Castles 2007, King 2012). This study meets the need to follow the life course of return migrants in a mixed methods approach, in order to perform a critical interrogation of the assumptions that inform host governments' policies on return migration and development.

\subsection{Research design: a two-phase study}

This study focuses on the life courses of return migrants, while building on two methodologically complementary research phases. The first phase is a comparative study, which combines quantitative and qualitative research methods in order to show general trends and context-specific differences. The second phase builds on the first with an in-depth case study that addresses the complexities of return migration. The design of these two different research projects is discussed below.

\subsubsection{Comparative study on return in six countries across the world}

The first research phase consists of a comparative study on return migration in six countries across the world, which was conducted between August 2007 and January 2008 by a team of six researchers under the coordination of the author. The study was commissioned by the Mediation Agency for Return (Maatwerk bij Terugkeer), which provides assistance to rejected asylum seekers and undocumented migrants who return. The Mediation Agency for Return's aim was to investigate the role of return assistance on the sustainability of return. The study took a broader approach to this question by looking at a wider range of factors that influence the post-return embeddedness of involuntary return migrants. The countries of return under investigation were Afghanistan, Armenia, Bosnia and Herzegovina, Sierra Leone, Togo and Vietnam. These countries were selected for their high return rates from the Netherlands or because they were otherwise of interest to the Mediation Agency for Return; the aim was also to have a wide geographic diversity.

The study took a mixed methods approach, using a combination of standardized quantitative and qualitative methods. In each country, a researcher spent two months gathering data through a structured survey, semi-structured interviews with returnees and key informants, and participatory observation. The analysis was based on the individual country reports, the combined quantitative database, and comparative field visits by the author to the research countries. The findings identified both general patterns and context-specific differences between the countries.

In total, 178 return migrants were interviewed. They had left their country of origin in a period of conflict or crisis and had returned from industrialized countries without having the right to stay legally, as they were rejected asylum seekers and undocumented migrants. Most respondents had returned from the Netherlands, the United Kingdom and Germany, where they had lived under diverse circumstances. The respondents had returned after their temporary asylum status had expired or their asylum claim had been rejected or after they had lived in the country as 
undocumented migrants. An additional criterion was that they were older than 18 years. Returnees were contacted through the Mediation Agency for Return, through networking in the country of return and through snowball sampling. Some interviews were conducted directly by the researchers in Dutch or English, while others were conducted with the help of a translator. Table 2.1 shows the number of respondents per country.

Table 2.1 Numbers of respondents per country in comparative study

\begin{tabular}{|lrrrr|}
\hline Number of respondents per country & Male & Female & Total & $\%$ \\
\hline Afghanistan & 27 & 1 & 28 & 16 \\
Armenia & 13 & 19 & 32 & 18 \\
Bosnia and Herzegovina & 17 & 19 & 36 & 20 \\
Sierra Leone & 36 & 5 & 41 & 23 \\
Togo & 15 & 5 & 20 & 11 \\
Vietnam & 19 & 2 & 21 & 12 \\
\hline Total & $\mathbf{1 2 7}$ & $\mathbf{5 1}$ & $\mathbf{1 7 8}$ & $\mathbf{1 0 0}$ \\
\hline
\end{tabular}

Source: comparative return migration study in six countries, 2007

As the impact of assistance was a key question in this study, an attempt was made to sample equally between returnees who had been assisted by the Mediation Agency for Return, returnees who had been assisted by other organizations, and returnees who had not been assisted by any institution or organization. However, it appeared that the distinction between non-assisted and assisted returnees was not very clear; almost all returnees had received some kind of assistance at some stage. For a better determination of the particular kinds of assistance that had an influence on postreturn embeddedness, the factor 'assistance' was divided according to type, timing and source.

\subsubsection{Afghanistan: a case study of return}

The second research phase builds on the insights of the first by taking the case of Afghanistan in order to carry out more in-depth research to address the complexities of return migration. The fieldwork for this phase was conducted by the author in cooperation with an Afghan translator / assistant in Kabul between May and July 2012 during two field visits of one month each. The fieldwork was logistically facilitated by Cordaid Kabul. The study took both a broader and a deeper approach to return, by collecting and analysing the life histories of both voluntary and involuntary returnees.

The capital Kabul as a research site reflected the reality of return: approximately thirty per cent of all returnees settle in Kabul (Stigter 2006). This general number is higher for returnees from European countries: Afghans who migrate to Europe are more likely to be of urban background, and were more likely to return to Kabul (Turton and Marsden 2002). Of the respondents in this study, many returnees were born and raised in Kabul, others had migrated from the provinces to Kabul before they left the country, and a minority had previously lived in the provinces but returned to Kabul. 
The participants in this study included 35 Afghan voluntary and involuntary returnees, returning mainly from Western Europe, and mostly from the Netherlands, the United Kingdom, Germany and Scandinavia. Tables 2.2 and 2.3 show their characteristics and their participation in the study.

Table 2.2 Respondents in Afghan return migration study - Involuntary return migrants

\begin{tabular}{|lllrrrlr|}
\hline No. & Name ${ }^{1}$ & Sex & Birth $^{2}$ & Left & Return & Host country & Contacts $^{3}$ \\
\hline 1 & Kamal & $\mathrm{m}$ & 1978 & $1999 ?$ & 2006 & Netherlands & 4 \\
\hline 2 & Ajmal & $\mathrm{m}$ & 1978 & 2001 & 2004 & Netherlands & 4 \\
\hline 3 & Hamid & $\mathrm{m}$ & 1974 & 1998 & 2005 & Netherlands & 4 \\
\hline 4 & Omar & $\mathrm{m}$ & 1977 & 1994 & 2006 & UK a: $2000^{4}$ & 3 \\
\hline 5 & Wasim & $\mathrm{m}$ & 1976 & 1992 & 2007 & UK a: 2000 & 4 \\
\hline 6 & Mahmood & $\mathrm{m}$ & 1950 & 2000 & 2002 & Denmark & 3 \\
\hline 7 & Samir & $\mathrm{m}$ & 1971 & 1999 & 2005 & Netherlands & 1 \\
\hline 8 & Jamal & $\mathrm{m}$ & 1970 & 1997 & 2006 & Norway & 2 \\
\hline 9 & Wahid & $\mathrm{m}$ & $+/-1988$ & 2009 & 2011 & Netherlands & 1 \\
\hline 10 & Habib & $\mathrm{m}$ & $?$ & 2009 & 2012 & Netherlands & 1 \\
\hline 11 & Reza & $\mathrm{m}$ & 1967 & 1985 & 2005 & UK a: 2000 & 2 \\
\hline 12 & Iqbal & $\mathrm{m}$ & 1976 & 1996 & 2010 & UK a: 2002 & 2 \\
\hline 13 & Rafiq & $\mathrm{m}$ & 1977 & 1994 & 2002 & Germany & 1 \\
\hline 14 & Areef & $\mathrm{m}$ & 1981 & 1998 & 2010 & Netherlands $a: 2000$ & Netherlands \\
\hline 15 & Mahboob & $\mathrm{m}$ & $+/-1975$ & 2001 & $+/-2006$ & & \\
\hline
\end{tabular}

Source: Afghan return migration study, 2012

The respondents had lived in Western Europe in various circumstances and had returned to Kabul for the widest possible range of reasons, from being deported to returning for career opportunities. The categorization of voluntary and involuntary return is based on the analysis of the meanings of and motivations for return presented in chapter 5. Although binary categorizations such as temporary versus permanent return are inadequate (Jain 2012), the target group were long-term returnees who had preferably returned several years earlier.

Random sampling of returnees was impossible due to the non-transparent or 'hidden' character of the research population (Bloch 2008). Return migrants were selected through various sampling techniques: first, based on a list of the participants in the first research phase, second, through networking in Kabul and third, through snowball sampling, which is a useful technique for locating respondents when the subject of the research is sensitive and the population is hidden (Bloch 2008).

\footnotetext{
1 To protect the privacy of the participants in this study, all names are pseudonyms.

${ }^{2}$ Not all dates could be determined precisely. This is due to inaccuracies in (1) converting the Islamic to the Western calendar, (2) the Afghan birth certificate system and (3) the memory of respondents. Many dates are derived from the narrative and give an indication of the time frame of birth and migration history.

3 This is the number of interactions with the researcher, including interviews and informal and group meetings.

4 ' $a$ ' represents the year of arrival in the host country, when not the year of departure. A discrepancy between the year of leaving Afghanistan and the year of arrival in the host country indicates a period of living in neighbouring countries and, or travelling, which often took a substantial amount of time.
} 
Table 2.3 Respondents in Afghan return migration study - Voluntary return migrants

\begin{tabular}{|c|c|c|c|c|c|c|c|}
\hline No. & Name & Sex & Birth & Left & Returned & Host country & Contacts \\
\hline 1 & Salim & $\mathrm{m}$ & 1977 & 1992 & $2005 / 08^{5}$ & Netherlands & 3 \\
\hline 2 & Besharat & $\mathrm{m}$ & 1977 & 1992 & 2008 & Netherlands a: 1995 & 2 \\
\hline 3 & Yasir & $\mathrm{m}$ & $?$ & $?$ & $+/-2008$ & Netherlands & 1 \\
\hline 4 & Deena & $f$ & $?$ & $?$ & $2007 / 11$ & Netherlands & 3 \\
\hline 5 & Shafiq & $\mathrm{m}$ & 1974 & 1990 & $+/-2008$ & UK a: 1999 & 4 \\
\hline 6 & Nadir & $\mathrm{m}$ & 1978 & 1992 & 2002 & Netherlands & 3 \\
\hline 7 & Amir & $\mathrm{m}$ & 1979 & 1992 & 2010 & Netherlands & 2 \\
\hline 8 & Fuad & $\mathrm{m}$ & 1985 & 1992 & 2012 & Netherlands & 2 \\
\hline 9 & Eshan & $\mathrm{m}$ & 1976 & 1983 & 2010 & Germany & 3 \\
\hline 10 & Faisal & $\mathrm{m}$ & $+/-1957$ & 1997 & 2005 & Netherlands & 3 \\
\hline 11 & Samad & $\mathrm{m}$ & 1989 & 1997 & 2010 & Netherlands & 1 \\
\hline 12 & Najib & $\mathrm{m}$ & 1970 & 1984 & 2008 & US & 2 \\
\hline 13 & Usman & $\mathrm{m}$ & 1974 & 1986 & 2010 & Greece a: 1990 & 4 \\
\hline 14 & Tareq & $\mathrm{m}$ & 1987 & 1991 & 2008 & Netherlands a: 1992 & 1 \\
\hline 15 & Fahima & $f$ & $+/-1970$ & 1998 & 2004 & Netherlands & 4 \\
\hline 16 & Wahid & $\mathrm{m}$ & 1977 & 1995 & 2009 & Netherlands a: 1999 & 1 \\
\hline 17 & Zafar & $\mathrm{m}$ & 1979 & 1992 & 2010 & Netherlands a: 1994 & 1 \\
\hline 18 & Hamed & $\mathrm{m}$ & $+/-1985$ & 1992 & $2007 / 11$ & Netherlands a: 1994 & 2 \\
\hline 19 & Latifa & $\mathrm{f}$ & 1985 & 1992 & 2007 & UK & 2 \\
\hline 20 & Safiya & $\mathrm{f}$ & 1982 & $1992 ?$ & 2006 & Canada & 1 \\
\hline
\end{tabular}

Source: Afghan return migration study, 2012

Some interviews were conducted directly with the researcher in Dutch or English. Others were carried out with the help of a translator. An attempt was made to have at least two individual meetings with all respondents, although the high mobility of some respondents and the limited time frame of the fieldwork did not always allow this. The individual meetings lasted in total between one and five hours. In addition, many respondents participated in one or both of the group meetings that were organized.

\section{$2.3 \quad$ Research techniques}

While the comparative research phase had a mixed quantitative and qualitative approach, the Afghan case study had a strong qualitative focus. This section discusses all the research techniques that were used in this study.

\subsubsection{Quantitative survey}

For the comparative study, a standardized questionnaire was used to collect structured data and ensure comparability on the experience of migration and return

5 Two return dates indicate multiple migration and return movements. 
across the six countries. The questionnaire contained a series of structured questions around the following topics:

1. Individual characteristics: age, gender, education, family, ethnicity, religion;

2. Migration cycle experiences: reasons for migration, period abroad, living circumstances in host country, return conditions;

3. Pre- and post-return assistance: source, size, intensity, and timing of this support;

4. Psychosocial embeddedness: identity, belonging, safety, traumatic experiences;

5. Social network embeddedness: social networks and social relationships;

6. Economic embeddedness: income, employment, housing, access to education and health services;

7. Future prospects after return.

The dependent variables in this analysis represent three dimensions of embeddedness, each composed of different elements. We assigned scores to the answers to all components of each dimension of embeddedness, and normalized the final value over a range between 0 and 100, thus obtaining a 'score' for embeddedness on each dimension. Appendix 2.1 shows how these scores were constructed. The scores should be seen as relative rather than absolute indicators and as showing the variance in relation to other returnees. As embeddedness is a process, these scores are never static and embeddedness is never 'complete'.

The procedure for data analysis involved several steps. The analysis focused on the determinants of the different dimensions of embeddedness: economic, social and psychosocial. Three sets of explanatory variables were taken into account:

a. Return assistance: type, source and timing;

a. Individual characteristics of the return migrants;

b. Migration cycle: reason for migration, time and circumstances in the host country, and reasons for return.

We used ordinary least squares regression models with a 10 per cent significance rate to examine the effects of our explanatory variables on the three dimensions of embeddedness.

Given the sample size, the analysis had to be split into several phases. First, for each dimension of embeddedness we analysed the three different sets of explanatory variables. Second, we analysed the main determining variables for each dimension of embeddedness. The latter analysis demanded exclusion of variables, due to the sample size. The choice for these excluded variables was made by combining theoretical notions (i.e. focusing on the 'type of assistance' variables) with stepwise regression methods, thus analysing a model that was sparse but with much explained variance. The coefficients refer to unstandardized effects (including the standard error and level of significance) and the adjusted R-square indicates the general fit of the model. 


\subsubsection{Qualitative methods}

In order to give room to the non-static and non-normative understanding of embeddedness, qualitative methods were used in both phases of this study, although they obviously had a stronger focus in the in-depth case study. Below, I will elaborate on the mix of qualitative data collection methods, including life histories, participatory techniques, group meetings and key informants.

\section{Life histories}

In both research phases, life histories were used, though in very different ways. In the comparative study, semi-structured interviews with a life history character were conducted alongside the survey, in order to expand further on the issues addressed in the questionnaire and to acquire a better perspective of the meaning the individual returnees ascribed to their experience (Eastmond 2007). The semi-structured character of these interviews ensured comparability across the six countries.

In the Afghan case study, the autobiographical narrative was the core of the data collection. This semi-unstructured interview technique represented a way of obtaining a holistic understanding of the role of migration in the individual's life course, which is often more complex than merely an external trigger event (Findlay and Li 1997, Eastmond 2007), and more encompassing than is assumed in a 'before and after' migration perception (Lutz 1998). A life history approach therefore helps to overcome the over-generalized notions of migration and return (Davis, Kuipers, and Lutz 1995, Findlay and Li 1997, see also Nijhof 2000, O'Neill et al. 2002, Eastmond 2007).

Life histories are creative constructions or interpretations of the past, generated in specific contexts of the present and in relation to the audience (Eastmond 2007, Gibbs 2007). When telling their life history, respondents present their narrative as having a meaningful and coherent order, imposing on reality a unity that it does not inherently possess. Rather than a reconstruction of factual information, this narrative organization shows how individuals frame their story and ascribe meaning to their experiences from the perspective of today and in relation to the social context (Ewing 1990, Lutz 1998, Eastmond 2007, Gibbs 2007). In their narratives, people usually identify key events, key social actors, and high, low, and turning points that they consider to have shaped them. Common life history themes are relationships to others, belonging and separateness, closeness and remoteness, experience of moving and the idea of career (Gibbs 2007).

Life histories do not have inherent essential meaning to them; rather, they can be given different meanings by different interpreters (Nijhof 2000, Wood and Groger 2000). The different features of the narrative shape a system of meaning, determining the worldview that the interviewees claim as their own, which the researcher must analyse and place back in its larger context. It is the task of the researcher to outline and analyse the complex social problematics that the interviewee has developed in the life story (Chanfrault-Duchet 1991).

The way respondents manage, negotiate or reconcile internal inconsistencies, ambiguities and contradictions in order to create wholeness in their narratives and create a 'personal myth' is an important site of analysis for understanding how identity is constructed (Ewing 1990, Nijhof 2000, Buitelaar 2006). The biographical 
method is therefore an excellent way to study complex processes such as the sociospatial ambivalence of belonging of migrants and the way former happenings or crises are still experienced in the present (Eastmond 2007, Gibbs 2007, Amelina 2010, Meeus 2012).

Placed in their wider socio-political and cultural contexts, these stories can provide insights into how migrants seek to make sense of displacement and violence and re-establish their identities in ruptured life courses and communities (Eastmond 2007). They provide insights into how individuals have adapted to changes, created strategies of resistance and struggled to make sense of these changes (Lutz 1998, Bakewell 2010).

Stories are important not only for negotiating what has happened and what it means, but also for seeking ways of going forward (Eastmond 2007). Autobiographical narratives are used by the narrator to apply existing discourses and at the same time to introduce changes to their rules and conventions (Davis, Kuipers, and Lutz 1995, Buitelaar 2006). Stories can show how discourses confine and restrict, but also enable, the actions and choices of the narrators (Jackson 2002, Hitlin and Elder 2007, Davids 2011). In addition, the act of storytelling can in itself be a source of agency, as it can become 'a coping strategy that involves making words stand for the world, and then, by manipulating them, changing one's experience of the world' (Jackson 2002, 18, see also Emirbayer and Mische 1998).

\section{Participatory techniques}

In the Afghan case study, visual participatory techniques, notably timeline drawing and photographing one's own life, were used to assist the autobiographical exercise. First, in order to approach the autobiographical exercise from a different angle than the verbal one, I asked returnees to draw a timeline of their lives. A timeline is an accessible visual participatory technique that is minimally structured, which therefore allows people to impose their own forms of organization and to put their own order to their experiences (Bagnoli 2009) using their own frameworks of understanding and priorities of interest (Pain and Francis 2003). In this study, it was particularly interesting to see the meaning that people gave to their migration experience in relation to other life events. I asked participants to draw a line on a simple graph, with on the horizontal axis their life from birth to the present and into their expected future, and the evaluation of that life on the vertical axis, going up or down according to whether times were positive or negative.

Drawing a line representing the course of their lives showed beautifully what respondents perceived to be significant periods or turning-points in their lives. In addition, drawing the timeline gave participants some time to reflect on the issues that were explored (Gauntlett 2007, Bagnoli 2009). Many respondents who looked back at their timelines were amazed by the pattern they started to see, or commented on the balance between positive and negative periods.

The timelines also helped the respondents to be more concrete about their experiences, and therefore provided new input for more detailed descriptions about the course of their lives. They sometimes also revealed periods in the respondents' lives that did not come up in the life history, either because people did not feel a particular period was important or because they were uneasy about talking about that period (Bagnoli 2009). Although the technique itself adds little information (Pain and 
Francis 2003), it was a way to access a different type of experience and provided entrance points for further discussion.

Last, most respondents enjoyed the task of drawing their timeline. Although a few seemed to be insecure about doing it 'right', most could be persuaded to understand that any drawing they made was good, as long as it reflected their own experience. For the respondents, being released from the sometimes uncomfortable feeling that came from being interviewed and instead being asked to draw, often worked as an ice-breaker that changed the tone of the conversation. The qualities of the timeline were both complementary to and enhancing of the verbal life history.

A certain extent of participatory observation took place in home visits, attending celebrations and family dinners, although the security situation for both the researcher and the returnees sometimes limited the possibilities for this. When a home visit was not possible, we met at my office or guesthouse. As a replacement for participatory observation, I offered my respondents a disposable camera to make photos of their lives, which provided a basis for discussion. In turn, they were given a set of their own photographs. Five respondents eventually participated in this, and it led to lively discussions about the photographs they had taken. The low response to the camera proposal could be related to social and religious taboos about photographs.

\section{Group meetings}

In addition to the individual interviews and meetings, three group discussions were held with the returnees. The first meeting brought together 20 returnees, both voluntary and involuntary. The event was presented as a networking meeting in which returnees could discuss amongst each other the challenges they were facing and might help each other out with advice or practical support. The topics to be discussed were decided by the participants, and the discussion was facilitated by the researcher, which produced interesting topics and brought to the surface remarkable group dynamics.

The second and the third group discussions were separate meetings for voluntary returnees on the one hand and involuntary returnees on the other. They took place at a later stage of the fieldwork. While the first meeting uncovered the differences between the two groups, the separate meetings were meant to create a safe and informal environment for discussions among likeminded people. These discussions were structured around themes that came forward from the fieldwork. The informal atmosphere, which included sharing dinner, facilitated lively discussions.

In two of the group meetings, two members of the Afghan NGO and community theatre group AHRDO 6 were present to help facilitate the meetings. First, they observed and reflected on the group interaction. Second, they assisted in an experiment to use participatory theatre techniques as a research methodology. The use of participatory theatre as a research method is a largely unexplored area. The limited literature available highlights its potential as an emic research method that facilitates collaborative analysis, in which participants engage in the analysis of their own social group (Conrad 2004, Dennis 2009). Such techniques show the narratives of

\footnotetext{
${ }^{6}$ The Afghanistan Human Rights and Democracy Organization
} 
group identity and collective experiences (Kaptani and Yuval-Davis 2008), and complement individual life histories. Our experiment, using practical exercises and image theatre, gave both visual input and food for discussion on trust, differences between groups, norms and values. As the experiment came with many logistical challenges, and the amount of data it produced was small, there is no separate analysis of it included in this thesis. Nevertheless, the experiment was promising and gave reason to explore these techniques further in future research.

\section{Key informants}

In both research phases, several professionals working on the topic of migration and, or return were interviewed or met with in informal settings. These key informants included government representatives, spokespeople of international organizations and local NGOs, researchers and journalists. These talks and interviews helped to provide a general picture of the circumstances faced by returnees, and to obtain information on the type of work that organizations undertake in the field of return. Table 2.4 shows an overview of the stakeholders who were interviewed in each of the six countries.

Table 2.4 Key informants interviewed in the six countries under study

\begin{tabular}{|lrrrrrr|}
\hline Type of organization & $\boldsymbol{A F}$ & $\boldsymbol{A R}$ & $\boldsymbol{B H}$ & $\boldsymbol{S L}$ & $\boldsymbol{T O}$ & $\boldsymbol{V} \boldsymbol{N}$ \\
\hline Local government authorities & 2 & 3 & 1 & 1 & - & 1 \\
Embassies & 5 & - & - & - & - & 4 \\
International organizations & 9 & 7 & 6 & 3 & 4 & 6 \\
Local NGOs & 5 & - & 3 & 3 & 2 & 3 \\
Researchers / academics & 3 & 1 & - & - & - & 3 \\
Other & - & - & 1 & 1 & - & - \\
\hline Total & $\mathbf{2 4}$ & $\mathbf{1 1}$ & $\mathbf{1 1}$ & $\mathbf{8}$ & $\mathbf{6}$ & $\mathbf{1 7}$ \\
\hline
\end{tabular}

1. Total of key informants interviewed in 2007 and 2012.

Source: comparative return migration study in six countries, 2007; Afghan return migration study, 2012

\subsubsection{Discourse analysis}

The texts that were obtained from the life histories and group discussions during the in-depth case study were analysed through text- and discourse analysis. Discourse is defined as an interrelated set of texts, and the practice of their production, dissemination and reception that brings an object into being (Phillips and Hardy 2002). Talk or text is not seen as a resource for explaining behaviour, but as a behaviour in itself that is to be explained (Wood and Groger 2000). Our social worlds, including our identities, are produced, maintained and made real through discourses. Social interactions can thus only be fully understood with reference to the discourses that give them meaning. Social reality and our ability to act strategically are defined and limited by discourses, although we can also draw strategically upon them. We therefore need to understand discourse in order to understand peoples' reality, experiences and expressions (Phillips and Hardy 2002). 
Discourse analysis explores how texts are made meaningful and how they contribute to the constitution of social reality by making meaning (Phillips and Hardy 2002). The study of discourse is three-dimensional: it connects the analysis of texts to the analysis of text production and interpretation, locating them in a historical and social context (Fairclough 1992). Although we can never study all aspects of discourse and we inevitably have to select a subset of texts, we always have to make reference to broader discourses, to acknowledge the location of individual texts in larger bodies of texts, and to pay attention to this three-dimensional nature (Phillips and Hardy 2002).

A systematic approach to textual analysis as part of discourse analysis looks not only at the content of the text, but also at its texture or organization (Fairclough 1992). For a well-founded interpretation of the organization of discourse in the narratives of individual returnees and group discussions, a systematic analysis is necessary. For this purpose, the data was carefully transcribed, coded and systematically analysed in a continuously reflexive process based on the steps proposed by Wood and Groger (2000) and Gobo (2008):

1. Familiarization. All the data was read several times during and after the data collection phase. During this familiarization process, categories or themes were identified through open coding. The themes emerged from what was found in the data against the background of the literature review and the research question. In addition, as the start of an iterative process that lasted throughout the data analysis, key phrases, interpretations and meanings given to these themes were noted.

2. Standardization. All texts were divided into segments using Atlas.ti.

3. Coding. All segments were coded in Atlas.ti using one or more of 12 identified themes, and then re-read to verify whether all segments were assigned to the right themes. The themes were then sub-coded. For each code and sub-code, interpretations found in the data were noted. Appendix 2.2 shows a list of the main codes and their sub-codes.

4. Mapping out relations. Based on the previous reading, coding and co-occurrence checks, the relations between the codes were visualized using the network building tool in Atlas.ti and these relations were described in a first general narrative. This is similar to what Gobo calls the construction phase, where a number of hypotheses are formulated based on the data (Gobo 2008).

5. Re-reading. The coded data was printed and re-read in its original form, in order to identify discursive patterns within the texts.

6. Writing. In the last step, the narrative of the analysis was written in what Gobo calls the confirmation phase (Gobo 2008).

For the coding exercise, the software programme Atlas.ti was used. Although Computer-Assisted Qualitative Data Analysis Software such as Atlas.ti cannot take over the process of analysis, it can assist it in several ways. First, it facilitates the systematic and consistent organization and coding of qualitative data, which improves the reliability of the analysis. Second, several tools in the software assist the qualitative data analysis, making it possible to detect co-occurring codes indicating relationships among categories and to map relationships in networks (Gobo 2008, 
252-254). This systematic analysis was complemented with a more intuitive and creative approach in order to find patterns in the data.

\subsection{Methodological challenges and ethical considerations}

This section elaborates on the methodological choices and challenges and ethical considerations that came to the fore in this study, in order to enable a proper judgement to be made about the validity of the findings. An important methodological choice to highlight is that the focus of analysis is a comparison of the different categories of returnees. The study, however, does not systematically compare migrants and non-migrants, or the pre-migration and post-return situation of migrants, although the results do touch upon these issues.

An immediate methodological challenge was that return migrants from Europe proved to be a hidden population (Bloch 2008) for a number of reasons. First, returnees from industrialized countries are relatively small in number. Second, institutional constraints often make access problematic. As there is no central administration or long-term monitoring system for returnees, they are easily lost track of after they have returned (Jacobsen and Landau 2003, Eastmond 2007). Third, while voluntary returnees are quite visible in society, involuntary returnees typically do not want to declare themselves. Tracing them was therefore a labour-intensive task. The result was that the sample could not be randomly selected and was, in the case of the comparative study, relatively small. By diversifying my points of entry as much as possible, I tried to limit the negative effects of these limitations.

The characteristics of the research population inevitably led to a selection bias on multiple grounds. First, the labour-intensive sampling process in combination with time constraints meant that the fieldwork had an urban focus. Although this also represents the reality of return, as described above, it implies that the results are not representative for return to more remote or rural areas. A second bias in both phases of the study was that the majority of returnees were male, reflecting a demographic reality that migratory movements are gender selective. This gender bias was particularly visible in the Afghan case study. Involuntary returnees were often men who had migrated alone and had returned alone before they had been able to bring their families to join them (Schuster and Majidi 2013). Female voluntary returnees were also a minority, which is consistent with observations that female migrants from developing countries are more reluctant to return to a country with greater gender inequality compared to the host country (Guarnizo 1997, Ammassari 2004, Castles, De Haas, and Miller 2014, 62). This reality, however, puts a strong male bias on the perspectives of the returnees that are presented, which needs to be taken into account in the analysis.

Third, the vulnerable position of a portion of the research group created issues of representativeness as well as ethical issues. Violence and displacement can affect trust and the willingness or ability to speak (Jacobsen and Landau 2003, Eastmond 2007). In this study, some return migrants could not be interviewed because they did not want to be recognized by the community as returnees (especially in Vietnam), had difficulties in speaking because they suffered from severe mental problems (in Sierra Leone), refused an interview out of anger and disappointment with 'the West' 
(Afghanistan), were untraceable or had already re-emigrated. These unresponsive groups are likely to represent the more vulnerable categories of returnees, thereby affecting the representativeness of this study. This methodological issue is also an ethical one, as researchers' involvement with vulnerable people in fragile and violent communities may put them at risk (Jacobsen and Landau 2003, Eastmond 2007).

For those who did agree to participate, especially in the Afghan case study, the interaction between the researcher and the respondent by definition affected the narrative that was constructed (Chanfrault-Duchet 1991, Nijhof 2000, King 2012). Some interviews were conducted directly with the researcher, who is a Dutch female, while others were carried out with the help of translators, who were local Afghan males. In addition, while some narratives were told in face-to-face conversations, others were told in the group meetings. Particularly when dealing with privacy-, culture- and gender-sensitive issues, these differences undoubtedly affected the narratives.

The fact that some interviews were conducted through translators also imposed limitations on the level of discourse analysis that could be done in the second phase of the study. The translators were carefully instructed about the importance of a translation that was as detailed as possible without any 'editing' in the process. Nevertheless, analysis on the level of the linguistic and grammatical organization of a text becomes problematic when applied to translated data (Fairclough 1992). For each text sample that is used in the analysis, I therefore provide information on the original language used, on whether the narrative was given through a translator and on whether it was expressed during an interview or in a group meeting.

The vulnerable position of some respondents also affected the narrative that was constructed (Chanfrault-Duchet 1991, Nijhof 2000). For some migrants, telling their life story telling had a negative connotation related to the memory of extensive interrogation during the asylum procedure. Especially if their narrative had not led to a positive asylum decision, this could 'undermine the premises of narrativity', creating a sense of isolation and mistrust in the respondent (Eastmond 2007, 261). Many of these returnees were reluctant or very brief and sometimes cynical about telling their life story. It was therefore crucial to create a safe and open atmosphere and to follow rather than lead the participants through the interview in terms of the topics and the pace. A good way to generate more trust and release the tension was to spread the interview over two or three meetings. In addition, the drawing of the timeline helped to break the ice and inspired the conversation, as mentioned above.

The other side of this vulnerability is that researchers of migration are likely to become incorporated into migrants' survival strategies. This may cause a methodological problem of reactivity, where the presence of the (Western) researcher influences the behaviour and responses of the informants, thereby compromising the research findings (Jacobsen and Landau 2003, Eastmond 2007). In this study, some returnees saw the researchers as representatives of their former host countries' governments. They were therefore either reluctant to share confidential information, or overemphasized their unfortunate situation, hoping they would receive some extra support. Much effort was therefore put into, at the minimum, building a relationship based on real expectations. It was always explicitly highlighted that the researcher was part of an independent university and not a representative of any government. This statement was, on the one hand, meant to highlight the confidential treatment of 
the information the respondents provided. On the other hand, it made it clear that while the respondents' participation in the study could possibly influence future policies on migration, it would not affect their personal situation either positively or negatively.

The implementation of each research phase also came with specific challenges related to the research design. In the comparative research phase, applying one standardized survey on six politically, geographically, economically and culturally different countries came with some limitations. First, as the scope of the research project did not allow for a pilot study, a number of flaws were left in the survey. Some questions were too abstract or were not relevant to the specific context of some countries. In addition, the questionnaire was often found to be too long. To adjust the applicability of the surveys, some of the questions were reformulated in the field. Second, the complex reality of migration made it hard to perform an analytical separation of the weight of the explanatory variables, which were in reality interrelated. Nevertheless, the mixed methods approach allowed the research team to compare and interpret the quantitative and qualitative data, which showed consistent and meaningful results.

The main challenge of the second, in-depth and qualitative, phase of the study was to deal with issues of validity and reliability. As life histories are constructed in a particular moment and in relation to a particular audience, it is important to investigate whether the discourses that are recognized in the life histories are also present outside of those texts. This was done by means of triangulation procedures; the combined use of different methodologies in the analysis of a phenomenon. By using the discourse analysis of the life history accounts alongside group discussions and key informants' interviews, and comparing them with the results from the comparative study, consistent results confirmed the reliability of the findings (Gobo 2008).

A final methodological consideration was the operationalization of embeddedness. In the first research phase, putting the inherently subjective and nonnormative concept of embeddedness into quantitatively measurable and comparable variables that were valid over six different countries presented a challenge. By combining quantitative scores for embeddedness with a thorough qualitative understanding of the context and the narratives of the returnees, these scores could be interpreted in a meaningful way, which highlights the value of the mixed methods approach. In the second research phase, new insights emerging from the emic approach of the study called for a change in the operationalization of the concept of embeddedness. First, I decided to replace the psychosocial dimension by a cultural dimension. While a cultural dimension still picks up identity issues, it focuses more on the relational aspect rather than an internal state of being, which therefore fits better into the concept of embeddedness. Second, institutional embeddedness proved to be a relevant addition to take into account. While this causes a discontinuity between the first and the second phase of this study, the core understanding of embeddedness as a holistic and multidimensional approach remains intact in both phases. Moreover, the change of operationalization reflects a learning process over the course of this $\mathrm{PhD}$ trajectory. 


\subsection{Conclusion}

In this chapter I highlighted the methodological points of departure, and the methods, benefits and challenges of the two research phases on which this thesis is based. Combining these complementary approaches helped to discover some remarkable trends in return migration and to highlight the complexity and meanings of return migration. The next chapters will present the empirical results of the study. 


\section{Appendix 2.1: Construction of embeddedness in comparative study}

The dependent variables economic, psychosocial and social networks embeddedness consist of several elements. To each of the categories of these elements, values between 0 and 100 were attributed, which is shown in the tables below. The mean of these values resulted in the final scores that were standardized in a range between 0 and 100.

\section{a. Economic embeddedness}

\begin{tabular}{|c|c|c|}
\hline Element & Category & Value \\
\hline \multirow{6}{*}{$\begin{array}{l}\text { Ownership of assets } \\
\text { (added up: } \max 100 \text { ) }\end{array}$} & Savings & 15 \\
\hline & House & 30 \\
\hline & Land & 20 \\
\hline & Car and/or motorbike & 15 \\
\hline & Farm animals & 5 \\
\hline & Working materials and/or business & 15 \\
\hline \multirow[t]{2}{*}{ Having an income } & Yes & 100 \\
\hline & No & 0 \\
\hline \multirow[t]{9}{*}{ Independency of income ${ }^{7}$} & Independent & 100 \\
\hline & 1st Independent +2 nd semi dependent & 85 \\
\hline & 1st Independent +2 nd dependent & 75 \\
\hline & Semi dependent & 55 \\
\hline & 1st Semi dependent +2 nd independent & 70 \\
\hline & 1st Semi dependent +2 nd dependent & 40 \\
\hline & Dependent & 30 \\
\hline & 1st dependent +2 nd independent & 55 \\
\hline & 1st dependent +2 nd semi dependent & 40 \\
\hline \multirow[t]{2}{*}{ Sufficiency income } & Yes & 100 \\
\hline & No & 0 \\
\hline \multirow{4}{*}{$\begin{array}{l}\text { Access to (stable) } \\
\text { employment }{ }^{8}\end{array}$} & Stable employment & 100 \\
\hline & Semi stable employment & 50 \\
\hline & Unemployed & 0 \\
\hline & Non labour force & 50 \\
\hline \multirow{3}{*}{$\begin{array}{l}\text { Access to health care and } \\
\text { education }\end{array}$} & Yes & 100 \\
\hline & Partially & 50 \\
\hline & No & 0 \\
\hline
\end{tabular}

Source: comparative return migration study in six countries, 2007

\footnotetext{
${ }^{7}$ Independent income: Salary / wage / interest; Semi-dependent income: Allowances / grants from relatives or friends, loans, remittances, living off spouses income, pension; Dependent income: Public relief, humanitarian assistance.

${ }^{8}$ Stable employment: In permanent wage labour or formal entrepreneur; Semi-stable employment: In temporary, daily or seasonal wage labour, or informal entrepreneur; Unemployed: in labour force but not working; Non-labour force: Housewife, student, retired.
} 


\section{b. $\quad$ Social embeddedness}

\begin{tabular}{|llr|}
\hline Element & Category & Value \\
\hline Sufficiency of social relations & Yes & 100 \\
& Yes, but would be better to have more & 60 \\
& No, not enough & 30 \\
& No, I do not have social relations at all & 0 \\
\hline Social relations help with: & Completely disagree & 0 \\
-Material needs & Somewhat disagree & 25 \\
-Emotional needs & Neutral & 50 \\
& Somewhat agree & 75 \\
& Completely agree & 100 \\
\hline Participation in association & Yes & 100 \\
& No & 0 \\
\hline
\end{tabular}

Source: comparative return migration study in six countries, 2007

\section{c. Psychosocial embeddedness}

\begin{tabular}{|llrr|}
\hline Element & Category & Value & (Inverted) $^{9}$ \\
\hline - Identity - 11 questions & Completely disagree & 0 & 100 \\
- Safety - 3 questions & Somewhat disagree & 25 & 75 \\
- Psychological - 3 questions & Neutral & 50 & 50 \\
& Somewhat agree & 75 & 25 \\
& Completely agree & 100 & 0 \\
\hline Feeling at home & Yes & & 100 \\
& No & & 0 \\
\hline
\end{tabular}

Source: comparative return migration study in six countries, 2007

\footnotetext{
9 These elements were questioned through a likert-scale, of which its categories were ranked according to whether the answer indicated a positive situation of their identity, safety and psychological wellbeing. Values therefore depended on the direction of the question.
} 


\section{Appendix 2.2: Main coding for Afghan return migration study}

\begin{tabular}{|c|c|}
\hline Main code & Category \\
\hline 01. (im)mobility & $\begin{array}{l}\text { 01.1 Reason to migrate } \\
\text { 01.2 Journey } \\
\text { 01.3 Asylum procedure } \\
\text { 01.4 Life abroad } \\
\text { 01.5 Return to Afghanistan } \\
\text { 01.6 Life post-return } \\
\text { 01.7 Current mobility after remigration } \\
\text { 01.8 Culture of mobility }\end{array}$ \\
\hline 02. Psychosocial & $\begin{array}{l}\text { 02.1 Self-identification } \\
02.2 \text { Home and belonging } \\
\text { 02.3 Interpretation of events } \\
\text { 02.4 Trends psychosocial } \\
\end{array}$ \\
\hline 03. Socio-economic & $\begin{array}{l}\text { 03.1 Education and learning } \\
\text { 03.2 Employment and career } \\
\text { 03.3 Housing } \\
\text { 03.4 Cash \& commodity } \\
\text { 03.5 Assets and savings } \\
\text { 03.6 Economic situation }\end{array}$ \\
\hline 04. Social network & $\begin{array}{l}\text { 04.1 Family } \\
\text { Nuclear family } \\
\text { Extended family } \\
04.2 \text { Network } \\
\text { Friends } \\
\text { Love affairs } \\
\text { Informal acquaintances } \\
\text { Functional acquaintances } \\
\text { Institutional network }\end{array}$ \\
\hline 05. Culture \& religion & $\begin{array}{l}\text { 05.1 Religion } \\
\text { 05.2 Ethnic \& regional \& kinship background } \\
\text { 05.3 Class } \\
\text { 05.4 Generation: Young vs old } \\
\text { 05.5 Cultural expression } \\
\text { 05.6 Norms and values }\end{array}$ \\
\hline 06. Institutional & $\begin{array}{l}06.1 \text { Institutions } \\
06.2 \text { Politics } \\
06.3 \text { Corruption } \\
\text { 06.4 Residence }\end{array}$ \\
\hline 07. Violence \& conflict & $\begin{array}{l}\text { 07.1 Personal security issues } \\
07.2 \text { general security issues } \\
07.3 \text { Conflict analysis } \\
07.4 \text { Culture and violence }\end{array}$ \\
\hline 08. Life events / changing points & (co-coded with other codes) \\
\hline 09. future & (co-coded with other codes) \\
\hline 10. Different vs same & $\begin{array}{l}10.1 \text { Of (return) migrant } \\
10.2 \text { Of society }\end{array}$ \\
\hline 11. Support & $\begin{array}{l}\text { 11.1 Giving } \\
11.2 \text { Receiving }\end{array}$ \\
\hline
\end{tabular}

Source: Afghan return migration study, 2012 

Because homeland is one of the magical fantasy words like unicorn and soul and infinity that have now passed into language.

Zadie Smith - White Teeth, p. 332. 


\section{Determinants of post-return embeddedness}

Rethinking the role of return assistance as development

\subsection{Introduction 1}

Increasingly restrictive asylum policies in Europe have led to a discourse change in the field of migration, in which return back 'home' after conflict has become portrayed as a basic human right, restoring social order (Chimni 2000). Since the early 1990s, the UNHCR and other international bodies have promoted and facilitated return 'home' as the most desirable of all solutions for refugees (Malkki 1992, Stein and Cuny 1994, Hammond 1999, Zetter 1999, Omata 2013). In industrialized countries, return of rejected asylum seekers and undocumented migrants has come to be promoted through AVR programmes.

While voluntary consent was initially a requirement for repatriation, a strong interest in the return of unwanted migrants led host countries to anticipate on return much sooner than migrants themselves, through financial inducements or the threat of deportation. Several scholars therefore argue that these 'voluntary' return programmes are not based on a free and informed choice by the migrants. Instead, they are initiated by host governments who realize that they are less costly and politically less painful than enforced removal (Stein and Cuny 1994, Dimitrijevic, Todorovic, and Grkovic 2004, Blitz, Sales, and Marzano 2005, Black and Gent 2006).

Although onward irregular migration or undocumented residence in the host country are alternatives to return, several authors note that when participation in 'voluntary' return programmes is the only legal alternative, the notion of choice has little meaning (Turton and Marsden 2002, Blitz, Sales, and Marzano 2005, Black and Gent 2006, Zimmermann 2012). Even when no sanctions have been imposed and no force has been used, it is questionable whether return without a plausible (legal) alternative and under the threat of these sanctions can be called voluntary (Noll

\footnotetext{
1 This chapter is based on a study that was commissioned by Cordaid in 2007 and published in 2008. It merges two articles that were published based on the research report and adds an updated literature review. See:

Van Houte, Marieke, and Mireille De Koning. 2008. Towards a Better Embeddedness? Monitoring Assistance to Involuntary Returning Migrants from Western countries. Nijmegen / Amsterdam: CIDIN / AMIDSt.

- Van Houte, Marieke, and Tine Davids. 2008. "Development and Return Migration: from Policy Panacea to Migrant Perspective Sustainability." Third World Quarterly no. 29 (7):1411-1429.

- $\quad$ Ruben, Ruerd, Marieke Van Houte, and Tine Davids. 2009. "What Determines the Embeddedness of Forced-Return Migrants? Rethinking the Role of Pre- and Post-Return Assistance." International Migration Reviewno. 43 (4):908-937.
} 
1999). 'Voluntary' return programmes therefore, in practice, developed into the involuntary return of migrants who had no legal permission to stay and who returned because this was the 'least worse option' in a 'no win situation' (Chimni 1999, Dimitrijevic, Todorovic, and Grkovic 2004).

As part of the growing political interest in managing migration, governments of European countries ${ }^{2}$ have linked the return of refugees, rejected asylum seekers and undocumented migrants to migration and development policies (Black and Gent 2006, Frouws and Grimmius 2012, ICMPD and ECDPM 2013). Throughout the European Union, AVR programmes have therefore taken up a substantial part, if not the bulk, of migration and development policies, which are financed through ODA budgets (ICMPD and ECDPM 2013, Castles, De Haas, and Miller 2014, 70).

Even though these policies have been applied on a large scale throughout Western Europe, there has been surprisingly little monitoring of the post-return experience of these migrants. Therefore, no empirical justification existed for the use of development budgets for the return of unwanted migrants. This chapter is based on one of the first systematic studies on the post-return experience of this type of returnee. The study investigates the factors that influence post-return embeddedness, including return assistance, migration cycle experiences and individual characteristics. The concept of multidimensional embeddedness is defined as the process of an individual's identification with and participation in one or multiple spaces of belonging.

The study was conducted between August 2007 and January 2008 by a team of six researchers under the coordination of the author. Field research took place between August and October 2007 in six countries across the world: Afghanistan, Armenia, Bosnia and Herzegovina, Sierra Leone, Togo, and Vietnam. During a fieldwork period of two months in each country, we interviewed 178 return migrants. They had left their country of origin in a period of crisis and had returned from industrialized countries ${ }^{3}$ without having the legal right to stay, usually because their temporary asylum status had expired, their asylum claim had been rejected or they were an undocumented migrant. We took a holistic mixed methods life course approach, using a standard survey questionnaire combined with semi-structured life history interviews. ${ }^{4}$

In the remainder of this chapter, the conceptual issues around return migration are discussed. In addition, the concept of multidimensional embeddedness is introduced as an analytical framework for studying the dynamics of return migration and the factors that influence sustainable return. Based on the results, this chapter concludes that it is unjustified and misleading to suggest that AVR programmes promote development. Lastly, I discuss the implications for further research.

\footnotetext{
2 Notably Belgium, France, the Netherlands and Spain. See ICMPD and ECDPM (2013) for a systematic analysis of the migration and development policies of eleven European countries and of how these policies often include 'Assisted Voluntary Return' programmes.

${ }^{3}$ Mainly the Netherlands, the United Kingdom and Germany.

${ }^{4}$ Chapter 2 describes the methodologies used in this study.
} 


\subsection{Return migration and embeddedness}

Gmelch was the first to define return migration in the modern context, as 'the movement of emigrants back to their homelands to resettle' (Gmelch 1980, 135). In line with this, the humanitarian community conceptualized successful or sustainable return as reintegration, which envisages the 're-entry' of former refugees into the social, economic and cultural structures of their original community. Successful reintegration is defined as the disappearance of 'any observable distinctions which set returnees apart from their compatriots, particularly in terms of their socio-economic and legal status' (UNHCR 1997, 9, Dimitrijevic, Todorovic, and Grkovic 2004, Özerdem and Sofizada 2006).

However, more recent return migration literature has questioned all elements of Gmelch's definition and the notion of reintegration. First, the understanding of return as the mere physical movement of going back to one's country of origin, regardless of whether that movement is voluntary or forced, has been argued to be too limited, as it does not take into account the significance of the relational consequences of return (Cassarino 2006). Second, the notion of homeland is not self-evident, since going 'home' to the pre-conflict and pre-migration life (Malkki 1992) is impossible: the postwar economic, social, cultural and political situation in the society of origin is often very different from what people have left. In addition, migrants' identifications and their feelings of belonging change and become more complicated with each migration movement, leading to hybrid or 'in-between' identities and notions of 'home' (Hammond 1999, Ghanem 2003, Ghorashi 2003, Long and Oxfeld 2004b, Faist 2008, Monsutti 2008, Raghuram 2009, De Haas 2010). Third, the intention of a migrant does not have much explanatory value, as return intentions do not seem to predict actual behaviour. This is particularly true for involuntarily returning migrants who did not originally have any intention to return (De Haas 2005). In addition, intentions may change and returnees without intending or being willing to do so may end up staying, while those intending to stay may end up leaving. Fourth, the notion of resettling implies the normality of return to the place of origin and to a sedentary life. However, the study of return migration should recognize that return may not be to a fixed 'end point' but is rather part of a process of multiple migration movements (Veale and Kennedy 2011, Jain 2012).

Rather than mere return and reintegration, which imply reinstating what was disrupted by migration, any approach to return migration should take into account that the post-conflict moment is a new phase in a dynamic and ongoing process (Hammond 1999, Al-Ali, Black, and Koser 2001, Cassarino 2004, Faist 2008, Sinatti 2011, Jain 2012). Hammond argues that return should be studied from a more encompassing perspective and as a relational process in which the returnee establishes the social, political and economic ties that define him or her in a meaningful way as a member of a community (Hammond 2004). Likewise, Black and Gent (Black and Gent 2006) highlight that, for sustainable return, it is not only economic factors, but also the meaning that migrants attribute to their return in the social context of the country of return, that are important. The concept of multidimensional embeddedness, which I will elaborate on below, provides an encompassing framework for studying the complex experience of migration and return. 


\subsubsection{Embeddedness}

Embeddedness was introduced in its current meaning by Granovetter (1985), who used it to explain how individual economic actions are embedded in contextual factors such as social networks. Granovetter used examples of immigrants to explain embeddedness, because 'foreign-born communities represent one of the clearest examples of the bearing contextual factors can have on individual economic action' (Portes and Sensenbrenner 1993, 1322).

Granovetter's initially narrow understanding of embeddedness was extended into a multidimensional concept by subsequent scholars (Kloosterman, Van Der Leun, and Rath 1999, Kloosterman 2010). In this study, we defined the concept of multidimensional embeddedness as the process of an individual's identification with and participation in spaces of belonging. We studied three interrelated dimensions: (1) economic embeddedness, (2) social network embeddedness, and (3) psychosocial embeddedness.

First, the economic dimension of embeddedness requires access to resources, opportunities and basic services to establish a self-sustained livelihood (Dimitrijevic, Todorovic, and Grkovic 2004). Chambers and Conway $(1992,6)$ define a sustainable livelihood as 'the capabilities, assets and activities required for making a living'. In practice a livelihood can be defined as the extent to which an individual owns, or has access to, resources, assets and claims, such as income, housing, land, stock, transportation, education and health care. Livelihoods become sustainable when they can cope with and recover from stress and shocks, and maintain or enhance their capabilities and assets in the short and the long run (Chambers and Conway 1992, De Haan and Zoomers 2003). Such sustainability is of particular importance if return is to a society that is unstable because of the legacy of a conflict and, or a severe economic crisis.

Second, social network embeddedness refers to the possibilities for return migrants to become part of local social networks and to establish meaningful social contacts in the country of origin. Social networks are important for acquiring information, sharing personal and intimate relationships with peers, and discussing shared beliefs and values. These networks add to social capital, including social organization, reciprocity, networks, information flows and social safety nets. Social capital enables individuals in society to have a more efficient and stable position. It is not only the quantity and frequency of individual contacts that are important, but also the quality: social contacts become more valuable for material and emotional support when they provide some sort of closeness and the feeling that one can rely on another person. Cassarino (2004) states that such social networks are crucial for understanding the ways in which returnees mobilize resources while being involved in dynamic cross-border networks that are responsive to specific pre- and post-return conditions.

Third, psychosocial embeddedness refers to the ability to express identity, providing an individual with a place in society and establishing connections with that society (Giddens 1991). Identity formation can be defined as a dynamic view of the self and the other, 'constantly acquiring new meanings and forms through interactions with social contexts and within historical moments' (Ghorashi 2001, 22). The construction of identity takes place in practices and expressions including religion, 
rites of passages, language, dietary habits, and leisure activities (Bhugra et al. 1999, Ghanem 2003, Bhugra and Becker 2005). Migrants' identifications become more complicated and hybrid with each migration movement, while the community of return is also likely to have experienced changes. Whether returnees can again find a place of belonging on their return depends on the result of a negotiation process with the community of return that covers both distinctiveness and authenticity (Dwyer 2000, Chan and Tran 2011). Although migrants may try to combine the best of both worlds (Ghorashi 2003), their hybrid identifications can also create feelings of 'inbetweenness', leading to the loss of social structures, cultural values and self-identity (Bhugra and Becker 2005).

Although the dimensions of embeddedness are analytically separate, they are interdependent in the post-return lives of migrants, as displayed in Figure 3.1. For example, a limited economic embeddedness can negatively affect psychosocial embeddedness, and increases the significance of and dependency on social networks. A limited psychosocial embeddedness, in turn, increases difficulties in coping with the economic hardships faced upon return, affecting social networks, and so forth. The next section will identify a number of aspects that influence these interrelated dimensions of embeddedness.

\subsubsection{Factors determining post-return embeddedness}

Three sets of explanatory variables can be identified in the literature as possible determinants of multidimensional post-return embeddedness, which we took into account in the analysis (see Figure 3.1): (1) the effects of different modes (type, source and timing) of return assistance, (2) individual characteristics and (3) the circumstances of the migration cycle.

Monitoring return assistance was of primary interest in this study. Scholars analysing the effectiveness of return assistance have been quite pessimistic about it, for various reasons. Dolan (1999) and Hammond (1999) argue that policy makers' misinterpretation of return migration as a process of going 'home' leads to inefficient return assistance programmes. In addition, D'onofrio (2004) stresses that NGOs often use over-simplified parameters to measure the 'successfulness' of return, due to the limited time frame of the return assistance, and their desire to show tangible and measurable results. Consequently, most organizations involved in the return process are barely able to address the sustainability conditions of return. Dolan (1999) therefore concludes that assistance is an insignificant factor in the return process. With regard to timing, researchers highlight that the attention given to return migrants may abruptly end at the point of repatriation. Limited assistance is given after return, and the needs of returnees remain largely unacknowledged (Hammond 1999). 
Figure 3.1 Analytical framework of determinants of multidimensional embeddedness

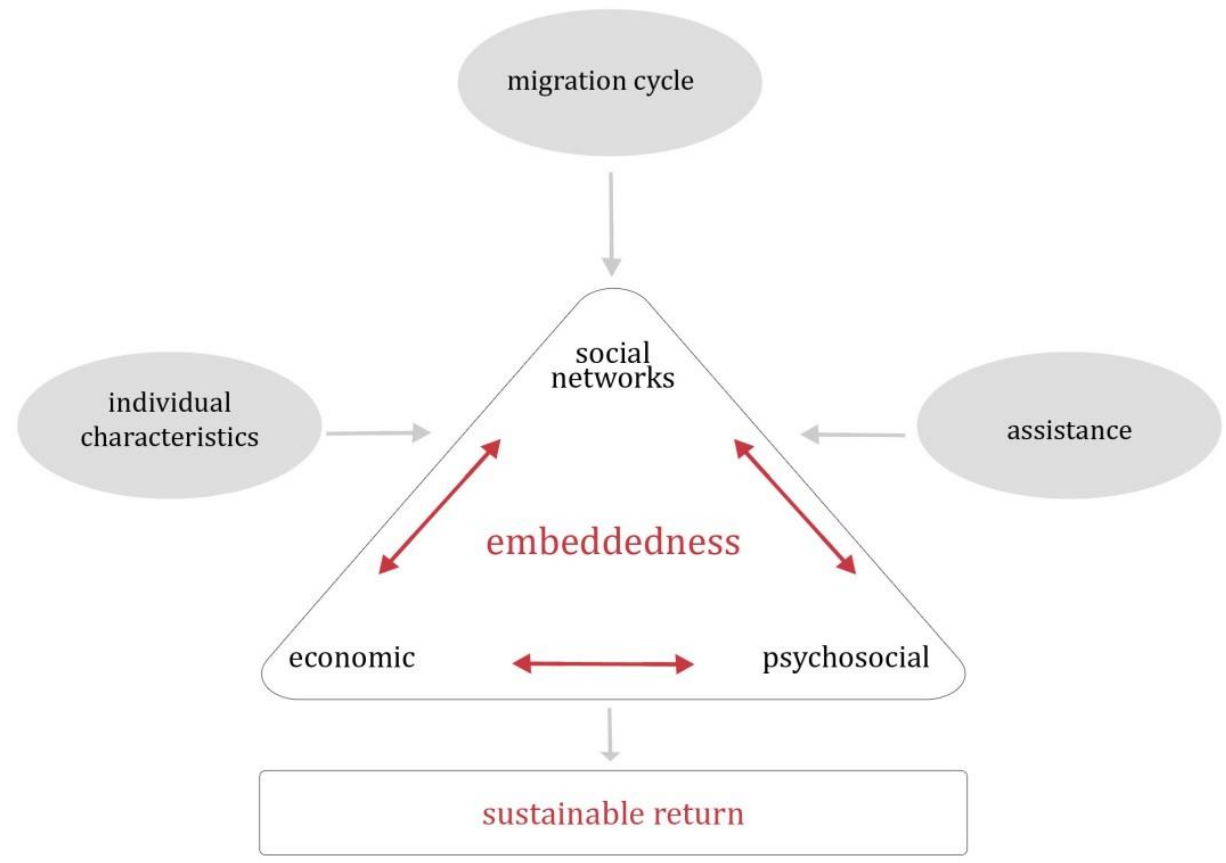

Source: Van Houte and De Koning 2008

A second set of variables that is mentioned as influencing post-return embeddedness consists of returnees' individual characteristics, such as age, socio-economic background, and marital status (Ghanem 2003). Gmelch (1980) stresses that younger migrants experience more difficulties upon return if they have spent a relatively large part of their lives outside their country of origin. Moreover, gendered differences in migration experiences are highlighted (Boyd and Grieco 2003). In addition, the return of migrants who are associated with particular socio-political categories such as ethnicity and religion could lead to societal tensions, which influences the post-return experience (Blitz, Sales, and Marzano 2005, Özerdem and Sofizada 2006).

With regard to the circumstances of the migration cycle, Boyd and Grieco (2003) distinguish three stages in the process of migration: the pre-migration stage, the stage of transition across state boundaries, and the post-migration stage in the new country. A migrant's economic, political, and personal opportunities in each migration stage are likely to influence the circumstances in the next stage. Return migration represents a fourth stage in this process, and is influenced by the experiences during the previous three stages. First, the original motives for out-migration influence the return migration process. Timotijevic and Breakwell (2000) find that radical sociopolitical upheavals followed by forced migration are threatening to self-identity. Unpredictable shocks in the lives of migrants and the belief that they cannot influence their life courses can negatively affect self-efficacy, self-esteem and trust in others.

Second, the living circumstances in the host country and the motivations for return can affect returnees' post-return embeddedness, in both negative and positive ways. Dimitrijevic and colleagues state that 'a prerequisite for sustainable return is 
that returnees' capacities for self-reliance are maintained or strengthened during exile' (Dimitrijevic, Todorovic, and Grkovic 2004, 38). In a similar vein, it has been argued that return migrants who studied and worked abroad benefit from this upon return (De Haas 2005). Cassarino therefore emphasizes the importance of willingness and readiness, based on the gathering of sufficient resources and information about post-return conditions in the country of origin. He argues that migration should have a sufficient duration that enables the returnee to mobilize resources to bring back (Cassarino 2004).

\subsection{Results}

We interviewed returnees in six countries that are geographically, politically, economically and socio-culturally very different. All the countries had been in some form of crisis at the time that the returnees had migrated, crises caused by conflict in combination with economic instability and a complex political situation. In Togo, a repressive militaristic regime, combined with ethnic violence and human rights violations from the 1980s onwards, resulted in large refugee flows. In Armenia, independence from and the collapse of the Soviet Union led to a severe and longlasting economic crisis from the beginning of the 1990s onwards. In Bosnia and Herzegovina, the collapse of Yugoslavia led to a bitter conflict over the independence of, and the rule over, the republic of Bosnia and Herzegovina, that was fought along ethnic lines between 1992 and 1995. In Sierra Leone, political struggles that took place in a power vacuum led to a civil war, with several parties fighting each other to gain power. In Afghanistan, decades of conflict started after the invasion by the Soviet Union and subsequent conflicts of competing parties in the years that followed (see chapter 4). In Vietnam, after the first wave of refugees had fled the communist regime from 1975 onwards, new flows of migration were triggered by the upward mobility and increased freedom of movement as a result of reforms in 1986 that intended to open the country up to the world market.

In these six countries, we interviewed 178 returnees, of whom 127 were male and 51 female. While all respondents had left their country of origin during a period of conflict or crisis, Table 3.1 shows that their individual motivations for migration were often mixed. While half of the sample population said they migrated because of the conflict, others referred to economic, personal and family reasons, or a mixture of these motivations. 
Table 3.1 Reason(s) for migration

\begin{tabular}{|lrr|}
\hline Reaon(s) for migration & Frequency & \% \\
\hline Conflict and fear & 88 & 49 \\
Economic & 32 & 18 \\
Personal and family & 27 & 15 \\
Combination conflict / economic & 15 & 8 \\
Combination conflict / personal & 4 & 2 \\
Combination economic / personal & 9 & 5 \\
Other & 2 & 1 \\
No answer & 1 & 0.6 \\
\hline Total & $\mathbf{1 7 8}$ & $\mathbf{1 0 0}$ \\
\hline
\end{tabular}

Source: comparative return migration study in six countries, 2007

The respondents had stayed, on average, for 4.1 years in industrialized countries, and fifty per cent of them ranged between 1.7 and six years. They had lived mostly in the Netherlands, the United Kingdom and Germany. Although none of the returnees had obtained permanent legal status to stay in the host country, they returned under varying degrees of choice. Table 3.2 shows that most respondents returned through AVR programmes after having had their asylum application rejected, or were forcibly returned after having lived as an undocumented migrant. A minority returned while still having a temporary right to stay, or for personal reasons.

Table 3.2 Circumstances of return migration

\begin{tabular}{|lrr|}
\hline Circumstances of return migration & Frequency & $\%$ \\
\hline 'Voluntary' with temporary right to stay & 28 & 16 \\
'Voluntary' with no legal right to stay & 70 & 39 \\
Pressured to return & 21 & 12 \\
Forcibly returned & 51 & 29 \\
Returned because of personal factors & 8 & 5 \\
\hline Total & $\mathbf{1 7 8}$ & $\mathbf{1 0 0}$ \\
\hline
\end{tabular}

Source: comparative return migration study in six countries, 2007

Most returnees received some type of assistance before, during or after return, either from public or private agencies or through family networks. Table 3.3 shows the frequency of the different types, sources and timing of assistance that were received by the respondents. The type of assistance could include financial (grants, incomegenerating assistance, travel expenses), material (funding for accommodation, medication, work materials) and non-material (human) support (information provision and psychosocial counselling).

A majority (94 per cent) of the respondents had access to some form of institutional assistance, at least to some extent. Important schemes in return assistance, especially after return, were host government programmes implemented through the International Organization for Migration (IOM) and programmes implemented by local organizations supported by European NGOs. There were large differences in scale, scope and approach among these agencies. Publicly funded institutions usually had large-scale programmes and relatively high budgets per 
returnee, but had inflexible arrangements. In contrast, NGOs had limited resources but could offer a more flexible approach, considering the specific needs of individual returnees. They generally worked with local partner organizations and could offer more tailor-made assistance to meet the specific needs of the returnees. However, these partner organizations often did not specialize in issues of return migration.

Table 3.3 Frequencies of type, source and timing of return assistance

\begin{tabular}{|lrr|}
\hline Type of assistance & Frequency & $\%$ \\
\hline Received any assistance & 174 & 98 \\
\hline Assistance source & & \\
Institutional & 167 & 94 \\
NGO & 123 & 69 \\
Host government & 120 & 67 \\
Origin government & 16 & 9 \\
Family / friend & 122 & 69 \\
\hline Type of assistance & & \\
Financial & 169 & 95 \\
Conditional financial & 163 & 92 \\
Business set-up & 53 & 30 \\
Non-material labour market assistance & 33 & 19 \\
Information & 162 & 91 \\
Other non-material assistance & 117 & 66 \\
Psychological / medical assistance & 35 & 20 \\
\hline Assistance period \& source & & \\
Pre-return & 164 & 92 \\
Pre-return NGO & 82 & 46 \\
Pre-return government & 106 & 60 \\
Pre-return friends / family & 77 & 43 \\
During return & 151 & 85 \\
Post-return & 157 & 88 \\
Post-return NGO & 90 & 51 \\
Post-return government & 36 & 20 \\
Post-return friends / family & 95 & 53 \\
\hline SOure: comparatie return migration study & & \\
\end{tabular}

Source: comparative return migration study in six countries, 2007

A majority of returnees had access to post-return assistance. Table 3.4 shows the type of post return assistance that was received by respondents. While a large variety of assistance was reported, the focus was usually on material and practical assistance. Monetary assistance was the most common, while other material and practical types of assistance, such as funds for (temporary) housing or medication, assistance with starting a business, or labour market training, were less frequently reported. Less tangible forms of assistance, such as information and psychosocial counselling, were even less frequently provided. 
Table 3.4 Post-return assistance received by respondents

\begin{tabular}{|lrr|}
\hline Type of assistance & Frequency & $\%$ \\
\hline Monetary & 103 & 58 \\
(Financial) assistance with starting business & 42 & 24 \\
Assistance in finding employment & 13 & 7 \\
Housing & 18 & 10 \\
Practical information & 27 & 15 \\
Arranging documents & 12 & 7 \\
Locating family members & 4 & 2 \\
Medical & 7 & 4 \\
Psychosocial & 3 & 5 \\
\hline
\end{tabular}

Source: comparative return migration study in six countries, 2007

\subsubsection{Post-return embeddedness}

The mixed methods approach provided insights into returnees' post-return embeddedness. In the survey, a range of questions was asked to review returnees' economic, social network and psychosocial embeddedness. Appendix 2.1 showed how the answers to these questions were translated into scores between 0 and 100 that gave an indication of an individual returnee's level of embeddedness on each dimension. These overall scores, displayed in Table 3.5, were further interpreted using the data from the semi-structured interviews, which will be described below.

Table 3.5 Embeddedness scores in percentage of respondents

\begin{tabular}{|llrrr|}
\hline Score & & Economic & Psychosocial & Social \\
\hline Low & $0-40$ & 30 & 39 & 26 \\
Middle & $41-70$ & 51 & 33 & 54 \\
High & $71-100$ & 15 & 35 & 19 \\
Missing & & 3 & 3 & 2 \\
\hline Total & & $\mathbf{1 0 0}$ & $\mathbf{1 0 0}$ & $\mathbf{1 0 0}$ \\
\hline
\end{tabular}

Source: comparative return migration study in six countries, 2007

\section{Economic embeddedness}

Economic embeddedness was measured by a combination of factors that included ownership of assets, sufficient and independent income, and access to health care and education. Together, these variables meant to assess whether returnees were able to maintain a sustainable livelihood that was sufficient, stable and independent. The general picture is that almost 80 per cent of returnees had severe difficulties in building up a sustainable livelihood in terms of income generation, employment, housing and access to services. In addition, a number of patterns come to the fore.

First, rather than benefiting from their migration experience, most return migrants in the study found themselves economically worse off than they were before they migrated. To illustrate this downward mobility, Table 3.6 shows the type of housing before migration and after return. It shows that many returnees in the sample experienced a setback in terms of housing conditions compared to their pre-migration situation. Only 21 per cent of the respondents (predominantly returnees in Armenia 
and Bosnia and Herzegovina) owned their own house, and almost half of former house owners now relied on other, often more expensive or insecure, options. 37 per cent resided with relatives.

Table 3.6 Type of housing pre-migration and post-return

\begin{tabular}{|llrrrrr|}
\hline & & \multicolumn{5}{c}{ Post-return (absolute and as a percentage of pre-migration) } \\
\cline { 2 - 7 } & $\begin{array}{r}\text { Own } \\
\text { house }\end{array}$ & $\begin{array}{r}\text { Rent } \\
\text { house }\end{array}$ & $\begin{array}{r}\text { With family } \\
\text { or friends }\end{array}$ & Other & Total \\
\hline $\begin{array}{l}\text { Pre- } \\
\text { migration }\end{array}$ & Own house & 28 & 9 & 8 & 4 & 49 \\
& & $57 \%$ & $18 \%$ & $16 \%$ & $8 \%$ & $100 \%$ \\
\cline { 2 - 7 } & Rented & 2 & 16 & 7 & 4 & 29 \\
& house & $7 \%$ & $55 \%$ & $24 \%$ & $14 \%$ & $100 \%$ \\
\cline { 2 - 7 } & With family & 4 & 16 & 45 & 6 & 71 \\
& or friends & $6 \%$ & $23 \%$ & $63 \%$ & $9 \%$ & $100 \%$ \\
\cline { 2 - 7 } & Other & 3 & 7 & 6 & 12 & 28 \\
& & $11 \%$ & $25 \%$ & $21 \%$ & $43 \%$ & $100 \%$ \\
\cline { 2 - 7 } & Total & $\mathbf{3 7}$ & $\mathbf{4 8}$ & $\mathbf{6 6}$ & $\mathbf{2 6}$ & $\mathbf{1 7 7}$ \\
& $\mathbf{2 1 \%}$ & $\mathbf{2 7 \%}$ & $\mathbf{3 7 \%}$ & $\mathbf{1 5 \%}$ & $\mathbf{1 0 0} \%$ \\
\hline
\end{tabular}

Source: comparative return migration study in six countries, 2007

Second, rather than enhancing the economic situation of the family household upon return, the returnees were a burden to the household. Table 3.7 shows the stability of employment before migration and after return.

Table 3.7 Employment ${ }^{5}$ pre-migration and post-return

\begin{tabular}{|llrrrrr|}
\hline & & \multicolumn{4}{c}{ Post-return (absolute and as a percentage of pre-migration) } \\
\cline { 2 - 7 } & & $\begin{array}{r}\text { Employed } \\
\text { stable }\end{array}$ & $\begin{array}{r}\text { Employed } \\
\text { Semi-stable }\end{array}$ & $\begin{array}{r}\text { Un- } \\
\text { employed }\end{array}$ & $\begin{array}{r}\text { Non-labour } \\
\text { force }\end{array}$ & Total \\
\hline $\begin{array}{l}\text { Pre- } \\
\text { migration }\end{array}$ & Employed & 26 & 12 & 25 & 4 & 67 \\
& stable & $39 \%$ & $18 \%$ & $37 \%$ & $6 \%$ & $100 \%$ \\
\cline { 2 - 7 } & Employed & 6 & 25 & 17 & 0 & 48 \\
& semi-stable & $13 \%$ & $52 \%$ & $35 \%$ & $0 \%$ & $100 \%$ \\
\cline { 2 - 7 } & Unemployed & 4 & 3 & 9 & 1 & 17 \\
& & $24 \%$ & $18 \%$ & $53 \%$ & $6 \%$ & $100 \%$ \\
\cline { 2 - 7 } & Non-labour & 10 & 13 & 15 & 5 & 43 \\
& force & $23 \%$ & $30 \%$ & $35 \%$ & $12 \%$ & $100 \%$ \\
\cline { 2 - 7 } & Total & $\mathbf{4 6}$ & $\mathbf{5 3}$ & $\mathbf{6 6}$ & $\mathbf{1 0}$ & $\mathbf{1 7 5}$ \\
& & $\mathbf{2 6 \%}$ & $\mathbf{3 0} \%$ & $\mathbf{3 8 \%}$ & $\mathbf{6 \%}$ & $\mathbf{1 0 0 \%}$ \\
\hline
\end{tabular}

Source: comparative return migration study in six countries, 2007

The table shows that although 56 per cent of all respondents were (self-)employed, the majority were in semi-stable employment, which implied that the continuity of their income was not guaranteed and that their income was often insufficient to meet

\footnotetext{
5 Stable employment: in permanent waged labour or formal entrepreneur; Semi-stable employment: in temporary, daily or seasonal waged labour, or informal entrepreneurship; Unemployed: in labour force but not working; Non-labour force: housewife, student, retired.
} 
their needs. Respondents who did not have (enough) income generated through a salary, waged labour or revenue from trade depended on loans, remittances, public relief, humanitarian assistance or allowances received from family members.

Third, many returnees were not sufficiently able to respond to shocks or to generate upward mobility for themselves or their children. For example, 39 per cent of the respondents reported not having access to medical services. When asked what they would do if they were to fall ill, many returnees stated that they would have to try to borrow money from relatives or friends, while others said that they saw no other option than to pray to stay healthy. In addition, many returnees reported that paying for education for their children or themselves was problematic. This economic vulnerability gave many returnees a feeling of insecurity in the unstable 'post-conflict' countries of return.

\section{Psychosocial embeddedness}

Psychosocial embeddedness was measured by indicators of psychological wellbeing, perceptions of safety, identity, and feeling 'at home'. The general picture here confirms earlier findings that return is not simply going home, for a number of reasons. With regard to psychological well-being, 68 per cent of the returnees said that they were still affected by traumatic experiences in their lives, which they defined by referring to depression, sadness, anger, stress, lack of sleep, restlessness, nightmares and physical symptoms such as heart conditions. In Bosnia and Herzegovina, five respondents had been diagnosed with Post Traumatic Stress Disorder. In Sierra Leone, the researcher met six returnees who could not be interviewed because of their severe mental health conditions. These symptoms were particularly mentioned in countries where civil war had been a reason for migration.

In addition to pre-migration experiences related to conflict and crisis, the experiences of living in the host country and involuntarily returning to the country of origin were mentioned as traumatic. The often restrictive and dependent living conditions and the constant insecurity about their status in the host country affected the returnees' psychological well-being. Among these returnees, passive attitudes and a lack of self-esteem were observed. Upon return, disappointed or denigrating reactions from their relatives led to feelings of uselessness and failure. In Afghanistan and Vietnam, returnees said they felt stigmatized for their perceived cultural degradation because they had lived in a 'Western' host country.

With regard to safety, 41 per cent of the respondents said they did not feel safe enough to live their lives without restrictions in the post-conflict or post-crisis country of return. In Sierra Leone, Bosnia and Herzegovina and Afghanistan especially, this feeling of unsafety directly affected returnees' lives, as they would not return to their pre-conflict home if it was located in an area that they considered as unsafe.

With regard to identity, almost 40 per cent of the respondents claimed that they had trouble expressing their identity as a returnee. 77 per cent of all respondents said that they had changed during their time abroad, referring to differences in ways of thinking and talking when compared to the local population. Since these changes were often not evaluated as positive upon return, some returnees said that they preferred to conceal any different ideas or practices and their 'returnee' status by trying to readjust to the dominant culture. In contrast, returnees with a more positive and successful migration experience gained status from their newly acquired skills and 
were better received by their social network. As the changes in them also led to something meaningful for them and their family members, their behaviour was generally better tolerated.

\section{Social network embeddedness}

Social network embeddedness was measured by assessing whether returnees' social network provided them with access to information, goods, services, housing, employment and social support. Since returnees had been away for some time, they needed to invest in trusting relationships to reconstruct these networks. In general, a third of the respondents said they had enough social contacts in their country of origin to meet their needs. Most returnees only had a small network of people on whom they could rely, which put them in a vulnerable position. While returnees in Vietnam, Armenia and Bosnia and Herzegovina strongly relied on their nuclear family and other relatives, returnees in Togo and Sierra Leone indicated that they relied more on friends. In addition, 80 per cent of all returnees maintained transnational contacts, mainly with relatives who lived in industrialized or neighbouring countries. However, only 16 per cent said they received remittances from them.

The type of support that returnees could expect from their social networks varied greatly. A majority (73 per cent) of returnees said they could rely on their contacts for social and emotional support, which included feeling trust towards and comfort with their contacts, sharing experiences and spending time together. Married respondents strongly relied on their spouses for emotional support and for sharing their problems. It was, however, more difficult to find meaningful social contacts to fulfil material needs; 42 per cent said they could rely on their network for material support. In the first place, material support included accommodation, which meant having access to shelter and sharing in the household's assets and income. Furthermore, having access to meaningful networks could also help returnees to find employment or rebuild their livelihoods in other ways. However, only returnees from privileged socio-economic backgrounds seemed to have access to such strong social networks. In less wealthy families, returnees instead caused a burden to their relatives, as they stretched the already limited budget of the household, leading to tensions and frustrations with their relatives.

\section{Overall embeddedness and future perspectives}

The results show that the different dimensions of embeddedness are interdependent. Returnees with a weak economic embeddedness often relied on their relatives, and overcrowded housing and stretched household budgets could lead to increased social tensions, which then also affected psychosocial embeddedness. The other way around, weak social network embeddedness limited the possibility of becoming economically embedded. By contrast, a strong economic embeddedness positively affected returnees' post-return psychosocial embeddedness, which is strongly related to the way they were perceived by relatives and the society in the country of return.

A clear illustration of the overall low level of multidimensional embeddedness is that a large majority of respondents (76 per cent) stated that they would leave their country again if they had the chance to do so. Despite this desire, only 11 per cent were actually making plans to re-emigrate, while only 35 per cent of the population wanted to make serious efforts to become embedded. What remained was a group of 
people who did not have the means to leave but were unwilling to accept the fact that they were back in their country of return. These returnees were not likely to invest in their existence in the country of origin since they could hardly see any future prospects for themselves. This made these returnees an economically, psychosocially and socially very unstable group in the country of return.

\subsubsection{Factors affecting embeddedness}

What emerges from the above is that the biggest challenges for migrants upon return are building up an independent and sustainable livelihood, gaining trust and respect from social networks, and developing a feeling of belonging. Considering the obstacles that many returnees faced, it is of interest to see to what extent assistance helped to overcome these obstacles, and to look at the other factors that are of influence. Combining the results from the qualitative and quantitative data analysis, Table 3.8 shows the most important factors that became apparent as having an influence on post-return multidimensional embeddedness.

While the overall table shows the variety across the countries, the highlighted variables show the factors that came to the fore in all six countries in the study. The fact that a number of strong relationships could be identified across these very different countries of return on three different continents is remarkable. Therefore, the discussion below focuses on these general trends and context-specific particularities. In addition, Appendix 3.1 shows the results of the regression analysis per dimension of embeddedness.

\section{Return assistance}

The assistance provided before and after return by public and non-governmental organizations, whether in cash or in kind, proved to have a limited or even a significantly negative effect, particularly on economic, but also on social network and psychosocial embeddedness. This may not be surprising with regard to return assistance during return, as the arrangement of travel documents and plane tickets is directly associated with the negative experience of involuntary return. Nevertheless, the limited and negative effects of most types of assistance raise questions about the validity of the return assistance and development claims.

There are two notable exceptions of interventions that had positive effects, that may be used to explain why other interventions fail. First, the provider of the assistance proved to be of importance. Post-return assistance provided by NGOs had a significant positive effect. The qualitative data shows that the fact that NGOs have a more small-scale approach and do not represent the same institution as the one that put pressure on the returnees to return is influential. However, returnees also said they felt tricked into agreeing to return, and that promises by these NGOs, which they initially trusted, did not come true. In addition, returnees who received information from family and friends that informed their return decision were significantly better embedded after return, especially in Togo, Afghanistan and Armenia. These results may indicate that trust relations between the provider and the receiver of assistance are important, although the latter example also indicates a generally strong social network, which is in itself a dimension of post-return embeddedness. 
Table 3.8 Determinants of post-return embeddedness across the six countries

\begin{tabular}{|c|c|c|c|c|c|c|c|c|}
\hline & AF & AR & $\mathrm{BH}$ & SL & T0 & VN \\
\hline \multirow{5}{*}{$\begin{array}{l}\text { Individual } \\
\text { char. }\end{array}$} & \multicolumn{6}{|l|}{ Gender: male } & ++ & + \\
\hline & \multicolumn{2}{|c|}{ Marital status: married (if male) } & + & + & & + & + & + \\
\hline & \multicolumn{2}{|c|}{ Social class / education level: high } & + & + & - & ++ & & + \\
\hline & \multicolumn{2}{|c|}{ Age: middle (30-46) } & + & & + & + & + & + \\
\hline & \multicolumn{2}{|c|}{ Ethnicity / religion: reason to migrate } & + & & & + & + & \\
\hline \multirow{9}{*}{$\begin{array}{l}\text { Migration } \\
\text { cycle }\end{array}$} & \multicolumn{3}{|c|}{ Reasons to migrate: economic } & ++ & + & + & ++ & \\
\hline & \multicolumn{3}{|c|}{ Expectations of migration: temporary } & + & + & & + & ++ \\
\hline & \multirow{3}{*}{$\begin{array}{l}\text { Independent living } \\
\text { circumstances: }\end{array}$} & - Work & + & + & + & + & + & ++ \\
\hline & & - Housing & + & ++ & + & + & + & ++ \\
\hline & & - Social contact & + & + & & + & & + \\
\hline & \multicolumn{2}{|c|}{ Savings / remittances } & ++ & + & + & + & + & ++ \\
\hline & \multicolumn{2}{|l|}{ Contact with home } & + & + & + & + & + & \\
\hline & \multicolumn{2}{|l|}{ Motivation to return } & + & ++ & + & + & ++ & ++ \\
\hline & \multicolumn{2}{|l|}{ Years back } & + & + & + & ++ & & + \\
\hline \multirow[t]{5}{*}{ Assistance } & \multicolumn{2}{|c|}{ Pre-return NGO (info) } & & & - & - & & \\
\hline & \multicolumn{2}{|c|}{ Pre-return family /friends } & + & & & & ++ & + \\
\hline & \multicolumn{2}{|c|}{ Post return financial } & & & - & & ++ & + \\
\hline & \multicolumn{2}{|l|}{ Business assistance } & + & & & + & ++ & ++ \\
\hline & \multicolumn{2}{|c|}{ Non material / human } & & & - & & & + \\
\hline
\end{tabular}

+: significant positive relation

++ : strong significant positive relation

-: significant negative relation [blank]: no significant relation

Source: comparative study on return in six countries, 2007

A second exception is that assistance for setting up an independent business had a positive significant effect on embeddedness in almost all countries. This was remarkable, since the qualitative data showed that respondents were sceptical about this business assistance. The budget available was often not a credible amount to start a real business, and it was highlighted that being an entrepreneur requires skills that not every returnee possesses. Nevertheless, what seemed to explain the effect of business assistance on embeddedness was the encompassing approach that included financial assistance and human guidance, and incorporated returnees' social networks, thus touching upon all dimensions of embeddedness. Most other assistance programmes only address the economic challenges of building sustainable livelihoods, leaving aside the other, equally important, dimensions of embeddedness related to social networks and creating a feeling of belonging. These results suggest that a more integrated approach for assisting returnees is required, that addresses both material and human needs and focuses on the incorporation of returnees into social structures. 


\section{Individual characteristics}

Individual characteristics and background such as gender, class, education level and position in the household strongly influenced all dimensions of embeddedness. First, men were generally more strongly embedded than women. For women, especially when they were married and had children, their return meant a movement back to a traditional role in the household. This made them feel isolated, which affected their social and psychosocial embeddedness. In contrast, being married and having children had a positive influence on men's embeddedness, although men also suffered more from the burden of a failed migration experience and the responsibility of finding employment to take care of their dependants.

Second, class significantly affected embeddedness. Being part of a wealthy family provided better access to influential networks that could help returnees find employment, housing or other assets. In Afghanistan, Sierra Leone and Vietnam in particular, this helped returnees to make a start with rebuilding their lives. Related to this, higher education also had a positive effect on embeddedness if this was perceived as important in the country, which it was in Vietnam and Sierra Leone, but not in Armenia, Bosnia and Herzegovina or Togo.

Third, middle-aged migrants (aged 30-46) were economically and psychosocially better embedded upon return than either younger or older returnees. While younger returnees (aged 18 to 30 ) often faced a gap in their education or vocational training and had less attachment to their country of return, the older age of returnees aged 47 and above was a disadvantage in the context of high unemployment rates.

Fourth, although it was expected that ethnic or religious differences would affect post-return embeddedness, no clear patterns could be identified, which highlights the fact that, despite some strong patterns, return is also strongly context-specific and needs in-depth investigation. Although the statistical analysis showed that being part of an ethnic minority positively affected returnees' embeddedness in Togo and Sierra Leone, qualitative data neither supported nor provided a plausible explanation for this. In Afghanistan, people who claimed that they did not belong to any group were significantly better embedded, while in Armenia and Vietnam no effect could be found based on religion or ethnicity. However, differences in ethnicity, religion, and political background were problematic when they were directly related to civil war and the reason to migrate. The strongest example of this was the case of Bosnian returnees who, as a result of the war, had become part of an ethnic minority in their place of origin and therefore faced serious constraints on returning to their homes.

\section{Migration cycle}

The experiences in the migration cycle proved to be of critical importance to postreturn embeddedness. First, the reason for migration and the expectations of migration played an important role. If returnees had migrated for security reasons and had expected to be granted refugee status, this negatively affected their postreturn embeddedness. In contrast, migrants who had migrated with the intention of earning some savings and then returning, which mainly applied to the Vietnamese and Armenian respondents, were more willing to accept their return. However, if their economic goals had not been achieved, they were still frustrated upon their return, which hindered their embeddedness. In addition, migrants who had left because of a conflict but who were informed upon arrival in the host country that their stay would 
be temporary, which was the case for Bosnians in Germany, were better embedded upon return. The fact that they had temporary permission to work and live an independent life, in combination with the clearly-stated prospect that they would eventually need to return, motivated them to maintain contacts in their country of origin, and mitigated their feeling of disappointment and failure upon return.

A second crucial factor in the migration cycle was the living conditions in the host country, since most returnees spent a significant period of time there. Migrants who had been able to maintain independent living conditions with regard to housing, employment or education, and had maintained social contacts, were significantly better embedded on all dimensions. Important advantages of independent living conditions in the host country were the feeling that migrants could control their own situation and lead an active life, and the strengthening of their social networks in the country of origin through sending remittances and eventually returning with some savings.

Working in the host country did not necessarily improve these migrants' opportunities in the labour market upon return, since they often had low-skilled jobs that did not match their qualifications, and any new skills or knowledge were often not relevant to the type of employment available upon return. Nevertheless, being incorporated into a working environment abroad and generating their own income helped migrants to maintain their self-esteem and survival skills, which were crucial assets in the insecure post-return situation. In contrast, migrants who faced restrictive living conditions in the host society, and were held in dependent positions in asylum centres where they relied on social welfare, faced clear disadvantages on all dimensions of embeddedness. Next to a loss of survival skills, their return without savings or assets resulted in feelings of uselessness, relative failure and exclusion by their social network.

Last, one of the most important influencing factors of the migration cycle was the circumstances of return and the agency migrants had over their decision to return. Return as a result of pressure or force from the authorities of the host government had a strong negative impact on all dimensions of embeddedness and on the way returnees were perceived by the people in their home society. In Sierra Leone, for example, word spread quickly when a forced returnee arrived handcuffed and under the supervision of police officers. These returnees were often severely stigmatized, which affected their psychosocial embeddedness.

\subsection{Conclusion}

This chapter investigated whether the use of ODA for AVR programmes for rejected asylum seekers and undocumented migrants is justified. Using a mixed methods and comparative approach, it analysed the factors that influence post-return embeddedness, including return assistance, migration cycle experiences and individual characteristics, for 178 returnees in six countries across the world. In order to allow the understanding of return migration as a phase in a transnational process, the study took a life course approach, studying the experiences of leaving, staying in the host country and returning. In addition, the concept of multidimensional embeddedness was used in a holistic approach towards analysing and understanding 
the complex reality of return as a continuous process beyond simple 'reintegration' or 'going home'.

Return affects all dimensions of life including the establishment of an economic livelihood, the repositioning of oneself in social networks in the country of origin, and the attainment of a sense of belonging in society. Even though the degree of postreturn embeddedness varied amongst individual returnees in different countries, a number of general trends could be recognized, highlighting the overall difficulty for involuntary returnees to become embedded in the country of origin. In economic terms, the majority of the returnees managed to survive, but few were able to build up a sustainable livelihood with regard to housing and income. Many returnees were still highly vulnerable and lacked future prospects. Access to extended social networks proved to be crucial for returnees, since these networks contribute to feelings of belonging and enhance returnees' engagement in their country of origin. Even though many returnees have established social relationships, these often do not extend beyond family and close friends, and returnees may easily become a burden to the household budget. In psychosocial terms, problems related to traumatic experiences in the pre-migration period, a frustrating migration experience and feelings of unsafety upon return reinforce each other and tend to limit the feelings of belonging to the return society.

The process of post-return embeddedness is determined by a wide range of factors. The study shows context-specific factors as well as remarkably strong general trends across the six very different countries of return. The obstacles and opportunities faced by returnees are directly related to previous experiences in the migration cycle. The living circumstances in the host country and the motivation for return are of critical importance for the return process. Spending years in restricted circumstances that constrain freedom of movement, limit the possibilities for employment and education, and make them dependent on social welfare, damage migrants' self-esteem, survival skills and social networks. These damaging effects on the prospects for post-return embeddedness cannot be compensated by the limited return assistance that is provided. Apart from business assistance, the return assistance therefore had limited or even negative effects on all dimensions of embeddedness. The human dimension of assistance and the incorporation of all dimensions of embeddedness seemed important.

These findings reveal an inconsistency in Western European migration policies. While the intention is expressed, and budget is assigned, to make this type of return migration contribute to development, the intention is undermined by restrictive migration policies. There is a paradox in expecting return migrants, who were at a certain stage of their migration process defined as superfluous, to transform into actors of change upon their return. In contrast to these expectations, we found that returnees faced deprivation rather than benefitting from their migration experience. As achieving a sustainable return for the individual returnee is thus already a challenge, returnees cannot be expected to contribute to development. Rather, the opposite is true: returnees often represent a burden on their relatives' household budgets and strain already limited employment, health care and education facilities in the country of return.

It is therefore unjustified and misleading to suggest that AVR programmes may promote development. What follows from our findings is that if Western European 
governments are sincere in their intentions to make returnees contribute to development, they should do this instead by giving migrants more rights to live an independent life, notably including rights to employment while in the host country.

\subsection{Moving forward}

This study provided one of the first systematic analyses of the return experience of rejected asylum seekers and other unwanted migrants. The holistic and multidimensional framework of embeddedness proved to be a good angle, since it is a more encompassing and non-normative way of analysing a person's identification with and participation in society, beyond the ideas of 'reintegration' or 'going home'. The comparative approach identified general trends across six very different countries of return, revealing that migration and development policies that focus on return assistance are ineffective. The questions remain why these policies fail and under what circumstances return migrants are willing and able to contribute to development and peace-building.

Building on these findings, two considerations inform the way to move forward in the next phase of the study. First, with regard to the highly contextual reality of migration, the need for a deeper understanding of return and migration patterns calls for an in-depth approach. Castles argues that migration research that sees migration as a 'dynamic social process linked to broader patterns of social transformation' (Castles 2003, 26) can also better inform policy. Second, the strong influence of the experience of the migration cycle and the motivation to return suggests using a wider angle to look at return by incorporating more voluntary return motivations. These considerations informed the choice to perform an empirically grounded case study on a wide range of returnees to Afghanistan, in order to complement this comparative study. 


\section{Appendix 3.1: Regression analysis of comparative study}

\section{Economic embeddedness: main results}

\begin{tabular}{|c|c|c|c|}
\hline \multirow{2}{*}{ Assistance } & \multicolumn{2}{|l|}{ B } & \multirow{2}{*}{ S.E. } \\
\hline & & & \\
\hline Assisted by NGO & -8.747 & $* *$ & 4.728 \\
\hline Assisted by host country government & -1.568 & & 3.935 \\
\hline Assisted by institution & 14.621 & ** & 7.797 \\
\hline Assisted by family/friends & 2.788 & & 4.328 \\
\hline Received financial assistance & -12.580 & ** & 8.224 \\
\hline Received assistance in business set up & 11.072 & $* * *$ & 3.277 \\
\hline Received non material information assistance & -7.893 & ** & 5.672 \\
\hline Assistance pre-return family/friends & 1.440 & & 3.879 \\
\hline Assistance post-return NGO & 6.183 & ** & 3.929 \\
\hline \multicolumn{4}{|l|}{ Individual characteristics } \\
\hline \multicolumn{4}{|l|}{ Sex } \\
\hline \multicolumn{4}{|l|}{ Male (ref.) } \\
\hline Female & -0.553 & & 3.872 \\
\hline \multirow{2}{*}{\multicolumn{4}{|c|}{ Belonging to ethnic majority or minority }} \\
\hline No group (ref.) & & & \\
\hline Majority & -10.421 & $* * *$ & 4.365 \\
\hline Minority & -3.848 & & 4.745 \\
\hline Not majority. not minority & 17.991 & * & 13.796 \\
\hline \multicolumn{4}{|l|}{ Previous Education } \\
\hline \multicolumn{4}{|l|}{ No diploma (ref.) } \\
\hline Primary & -5.783 & & 4.861 \\
\hline Secondary & -5.510 & & 4.842 \\
\hline Vocational & 0.134 & & 5.386 \\
\hline Higher & 3.110 & & 5.745 \\
\hline Children & 7.214 & $* *$ & 3.554 \\
\hline Constant & 48.167 & $* * *$ & 9.777 \\
\hline \multicolumn{4}{|l|}{ Migration cycle } \\
\hline \multicolumn{4}{|l|}{ First reason to migrate } \\
\hline \multicolumn{4}{|l|}{ Economic reasons (ref.) } \\
\hline Unsafety due to conflict & 9.910 & $* *$ & 4.656 \\
\hline Personal unsafety due to conflict & 6.258 & $*$ & 4.323 \\
\hline Discrimination & -2.971 & & 6.388 \\
\hline Family reunion & 9.853 & * & 7.064 \\
\hline Other reasons & 11.572 & $* * *$ & 4.920 \\
\hline \multicolumn{4}{|l|}{ Expectations of asylum } \\
\hline \multicolumn{4}{|l|}{ Expected permanent asylum (ref.) } \\
\hline No expectations & -1.644 & & 4.725 \\
\hline Expected temporary asylum & 6.039 & $* *$ & 4.481 \\
\hline Did not apply for asylum & -1.252 & & 7.875 \\
\hline Other expectations & 0.501 & & 9.278 \\
\hline Duration abroad (months) & -0.041 & & 0.042 \\
\hline Remittances abroad & 10.421 & $* * *$ & 3.208 \\
\hline \multicolumn{4}{|l|}{ Reason for return } \\
\hline \multicolumn{4}{|l|}{ Voluntary (ref.) } \\
\hline Forced & -5.272 & ** & 3.409 \\
\hline Number of years back & 0.772 & & 0.652 \\
\hline Adjusted Rsquare & 0.368 & & \\
\hline
\end{tabular}

Source: comparative return migration study in six countries, 2007 
1a Regression of economic embeddedness on assistance

\begin{tabular}{|c|c|c|c|}
\hline & \multicolumn{2}{|l|}{ B } & S.E. \\
\hline Assisted by NGO & -14.747 & $* * *$ & 5.644 \\
\hline Assisted by host country government & -6.896 & $*$ & 5.203 \\
\hline Assisted by origin country government & -0.457 & & 6.127 \\
\hline Assisted by institution & 18.104 & $* *$ & 8.465 \\
\hline Assisted by family/friends & -9.172 & * & 6.429 \\
\hline Received financial assistance & -15.970 & $* *$ & 8.620 \\
\hline Received assistance in business set up & 9.902 & $* * *$ & 3.638 \\
\hline Received non-material labour market assistance & 4.739 & & 4.138 \\
\hline Received non-material information assistance & -9.231 & $*$ & 6.187 \\
\hline Received psychosocial or medical assistance & 0.794 & & 4.003 \\
\hline Assistance pre-return NGO & -2.224 & & 4.254 \\
\hline Assistance pre-return government & 4.842 & & 4.695 \\
\hline Assistance pre-return family/friends & 8.685 & $* *$ & 4.360 \\
\hline Assistance post-return NGO & 12.566 & $* * *$ & 4.766 \\
\hline Assistance post-return government & 5.396 & & 4.911 \\
\hline Assistance post-return family/friends & 3.949 & & 4.873 \\
\hline Constant & 57.940 & $* * *$ & 7.595 \\
\hline Adjusted Rsquare & 0.115 & & \\
\hline${ }^{*} p \leq 0.100 ;{ }^{* *} p \leq 0.050 ;{ }^{* * *} p \leq 0.010$ & & & \\
\hline
\end{tabular}

Source: comparative return migration study in six countries, 2007

1b Regression of economic embeddedness on individual characteristics

\begin{tabular}{|c|c|c|c|}
\hline & \multicolumn{2}{|l|}{ B } & S.E. \\
\hline \multicolumn{4}{|l|}{ Sex } \\
\hline \multicolumn{4}{|l|}{ Male (ref.) } \\
\hline Female & 5.72 & $* *$ & 3.957 \\
\hline Age & -0.298 & & 0.951 \\
\hline Age squared & -0.002 & & 0.011 \\
\hline \multicolumn{4}{|l|}{ Marital Status } \\
\hline \multicolumn{4}{|l|}{ Single (ref.) } \\
\hline Engaged & -3.392 & & 5.572 \\
\hline Married & 3.114 & & 4.683 \\
\hline Divorced & 1.581 & & 6.838 \\
\hline Widowed & 2.669 & & 8.941 \\
\hline Children & 10.935 & $* * *$ & 4.351 \\
\hline \multicolumn{4}{|l|}{ Belonging to ethnic majority or minority } \\
\hline \multicolumn{4}{|l|}{ Majority (ref.) } \\
\hline No group & 10.352 & $* *$ & 4.729 \\
\hline Minority & 7.315 & $* *$ & 3.604 \\
\hline Not majority. not minority & 33.845 & $* *$ & 14.721 \\
\hline \multicolumn{4}{|l|}{ Previous Education } \\
\hline \multicolumn{4}{|l|}{ No diploma (ref.) } \\
\hline Primary & -0.741 & & 5.183 \\
\hline Secondary & 3.309 & & 5.142 \\
\hline Vocational & 7.345 & & 5.944 \\
\hline Higher & 13.447 & $* *$ & 6.053 \\
\hline Constant & 44.058 & $* * *$ & 18.420 \\
\hline Adjusted R-square & 0.136 & & \\
\hline${ }^{*} p \leq 0.100 ;{ }^{* *} p \leq 0.050 ;{ }^{* * *} p \leq 0.010$ & & & \\
\hline
\end{tabular}

Source: comparative return migration study in six countries, 2007 
1c Regression of economic embeddedness on migration cycle

\begin{tabular}{|c|c|c|c|}
\hline & B & & S.E. \\
\hline \multicolumn{4}{|l|}{ First Reason to Migrate } \\
\hline \multicolumn{4}{|l|}{ Economic reasons (ref.) } \\
\hline Unsafety due to conflict & 7.118 & $*$ & 5.468 \\
\hline Personal unsafety due to conflict & 6.240 & & 4.959 \\
\hline Discrimination & -4.663 & & 7.737 \\
\hline Family reunion & 15.348 & $* *$ & 7.537 \\
\hline Other reasons & 17.517 & $* * *$ & 5.546 \\
\hline \multicolumn{4}{|l|}{ Expectations of asylum } \\
\hline \multicolumn{4}{|l|}{ Expected permanent asylum (ref.) } \\
\hline No expectations & -4.447 & & 5.540 \\
\hline Expected temporary asylum & 6.023 & & 5.226 \\
\hline Did not apply for asylum & 1.138 & & 9.471 \\
\hline Other expectations & -0.139 & & 10.701 \\
\hline Duration abroad (months) & -0.023 & & 0.050 \\
\hline \multicolumn{4}{|l|}{ Housing security in host country } \\
\hline \multicolumn{4}{|l|}{ Insecure (ref.) } \\
\hline Asylum & 0.876 & & 8.321 \\
\hline Semi-secure & 3.723 & & 8.296 \\
\hline Independent & 7.635 & & 8.596 \\
\hline \multicolumn{4}{|l|}{ Education abroad } \\
\hline \multicolumn{4}{|l|}{ No education (ref.) } \\
\hline Yes & -2.850 & & 3.794 \\
\hline Only language education & 0.370 & & 4.864 \\
\hline Employed abroad & 2.181 & & 3.746 \\
\hline Savings abroad & 3.982 & & 4.153 \\
\hline Remittances abroad & 6.435 & $*$ & 4.678 \\
\hline Contact abroad & 2.818 & & 4.632 \\
\hline Heath abroad & 3.141 & & 6.352 \\
\hline \multicolumn{4}{|l|}{ Legal status at point of return } \\
\hline \multicolumn{4}{|l|}{ Rejected (ref.) } \\
\hline Protection & -4.120 & & 5.555 \\
\hline In asylum procedure & -2.434 & & 4.943 \\
\hline Illegal status & -3.967 & & 5.441 \\
\hline Other status & 0.535 & & 11.157 \\
\hline \multicolumn{4}{|l|}{ Reason for return } \\
\hline \multicolumn{4}{|l|}{ Voluntary (ref.) } \\
\hline Forced & -5.752 & $*$ & 4.137 \\
\hline Number of years back & 1.162 & $* *$ & 0.630 \\
\hline Constant & 31.056 & $* * *$ & 12.538 \\
\hline Adjusted R-square & 0.191 & & \\
\hline
\end{tabular}

Source: comparative return migration study in six countries, 2007 


\section{Social network embeddedness: main results}

\begin{tabular}{|c|c|c|c|}
\hline \multirow{2}{*}{ Assistance } & \multicolumn{2}{|l|}{ B } & \multirow[t]{2}{*}{ S.E. } \\
\hline & & & \\
\hline Assisted by family/friends & -12.004 & $* * *$ & 4.930 \\
\hline Received non material labour market assistance & -7.287 & $*$ & 4.504 \\
\hline Received non material information assistance & 8.052 & & 6.339 \\
\hline Received psychological or medical assistance & -6.254 & $*$ & 4.396 \\
\hline Assistance pre-return NGO & -7.660 & ** & 3.761 \\
\hline Assistance pre-return government & -7.126 & $*$ & 4.402 \\
\hline Assistance pre-return family/friends & 12.061 & $* * *$ & 4.439 \\
\hline \multicolumn{4}{|l|}{ Individual characteristics } \\
\hline \multirow{2}{*}{\multicolumn{4}{|c|}{$\begin{array}{l}\text { Sex } \\
\quad \text { Male (ref.) }\end{array}$}} \\
\hline & & & \\
\hline Female & -12.166 & $* * *$ & 4.715 \\
\hline Age & -0.834 & & 1.043 \\
\hline Age squared & 0.009 & & 0.012 \\
\hline \multicolumn{4}{|l|}{ Belonging to ethnic majority or minority } \\
\hline \multicolumn{4}{|l|}{ Majority (ref.) } \\
\hline Nogroup & -4.950 & & 5.595 \\
\hline Minority & 7.801 & ** & 4.278 \\
\hline Not majority. not minority & 34.458 & ** & 15.576 \\
\hline \multicolumn{4}{|l|}{ Previous Education } \\
\hline \multicolumn{4}{|l|}{ No diploma (ref.) } \\
\hline Primary & -7.881 & * & 5.663 \\
\hline Secondary & -11.682 & $* *$ & 5.687 \\
\hline Vocational & -6.257 & & 6.791 \\
\hline Higher & -10.222 & ** & 7.008 \\
\hline Children & 11.361 & $* * *$ & 4.585 \\
\hline Constant & 55.830 & $* * *$ & 24.087 \\
\hline \multicolumn{4}{|l|}{ Migration cycle } \\
\hline \multicolumn{4}{|l|}{ First reason to Migrate } \\
\hline \multicolumn{4}{|l|}{ Economic reasons (ref.) } \\
\hline Unsafety due to conflict & 8.454 & * & 5.472 \\
\hline Personal unsafety due to conflict & -4.096 & & 5.233 \\
\hline Discrimination & -6.197 & & 7.873 \\
\hline Family reunion & 18.308 & ** & 8.477 \\
\hline Other reasons & 11.910 & $* *$ & 5.659 \\
\hline \multirow{2}{*}{\multicolumn{4}{|c|}{$\begin{array}{l}\text { Housing security in host country } \\
\text { Insecure (ref.) }\end{array}$}} \\
\hline & & & \\
\hline Asylum & 9.234 & & 9.177 \\
\hline Semi-secure & 15.845 & $* *$ & 9.206 \\
\hline Independent & 12.329 & $*$ & 9.308 \\
\hline \multicolumn{4}{|l|}{ Education abroad } \\
\hline \multicolumn{4}{|l|}{ No education (ref.) } \\
\hline Yes & 5.861 & * & 3.989 \\
\hline Only language education & 0.599 & & 4.868 \\
\hline Savings abroad & 6.323 & * & 3.857 \\
\hline \multicolumn{4}{|l|}{ Legal status at point of return } \\
\hline Rejected (ref.) & & & \\
\hline Protection & 9.605 & ** & 5.413 \\
\hline In asylum procedure & 10.539 & $* * *$ & 4.656 \\
\hline Illegal status & 9.622 & ** & 5.705 \\
\hline Other status & -7.823 & & 11.764 \\
\hline Adjusted R-square & 0.231 & & \\
\hline
\end{tabular}

Source: comparative return migration study in six countries, 2007 
2a Regression of social embeddedness on assistance

\begin{tabular}{|c|c|c|c|}
\hline & \multicolumn{2}{|l|}{ B } & S.E. \\
\hline Assisted by NGO & -2.696 & & 6.147 \\
\hline Assisted by host country government & -4.760 & & 5.665 \\
\hline Assisted by origin country government & -6.044 & & 6.671 \\
\hline Assisted by institution & -0.553 & & 9.223 \\
\hline Assisted by family/friends & -11.835 & $* *$ & 7.016 \\
\hline Received financial assistance & 6.569 & & 9.390 \\
\hline Received assistance in business set up & 4.802 & & 3.977 \\
\hline Received non material labour market assistance & -6.264 & * & 4.506 \\
\hline Received non material information assistance & 4.494 & & 6.736 \\
\hline Received psychosocial or medical assistance & -7.943 & ** & 4.358 \\
\hline Assistance pre-return NGO & -11.529 & $* * *$ & 4.655 \\
\hline Assistance pre-return government & -9.358 & $* *$ & 5.126 \\
\hline Assistance pre-return family/friends & 10.319 & $* *$ & 4.747 \\
\hline Assistance post-return NGO & 8.410 & $*$ & 5.194 \\
\hline Assistance post-return government & 11.470 & $* *$ & 5.347 \\
\hline Assistance post-return family/friends & 5.441 & & 5.305 \\
\hline Constant & 55.318 & $* * *$ & 8.268 \\
\hline Adjusted R-square & 0.081 & & \\
\hline${ }^{*} \mathrm{p} \leq 0.100 ;{ }^{* *} \mathrm{p} \leq 0.050 ;{ }^{* * *} \mathrm{p} \leq 0.010$ & & & \\
\hline
\end{tabular}

Source: comparative return migration study in six countries, 2007

\section{2b Regression of social embeddedness on individual characteristics}

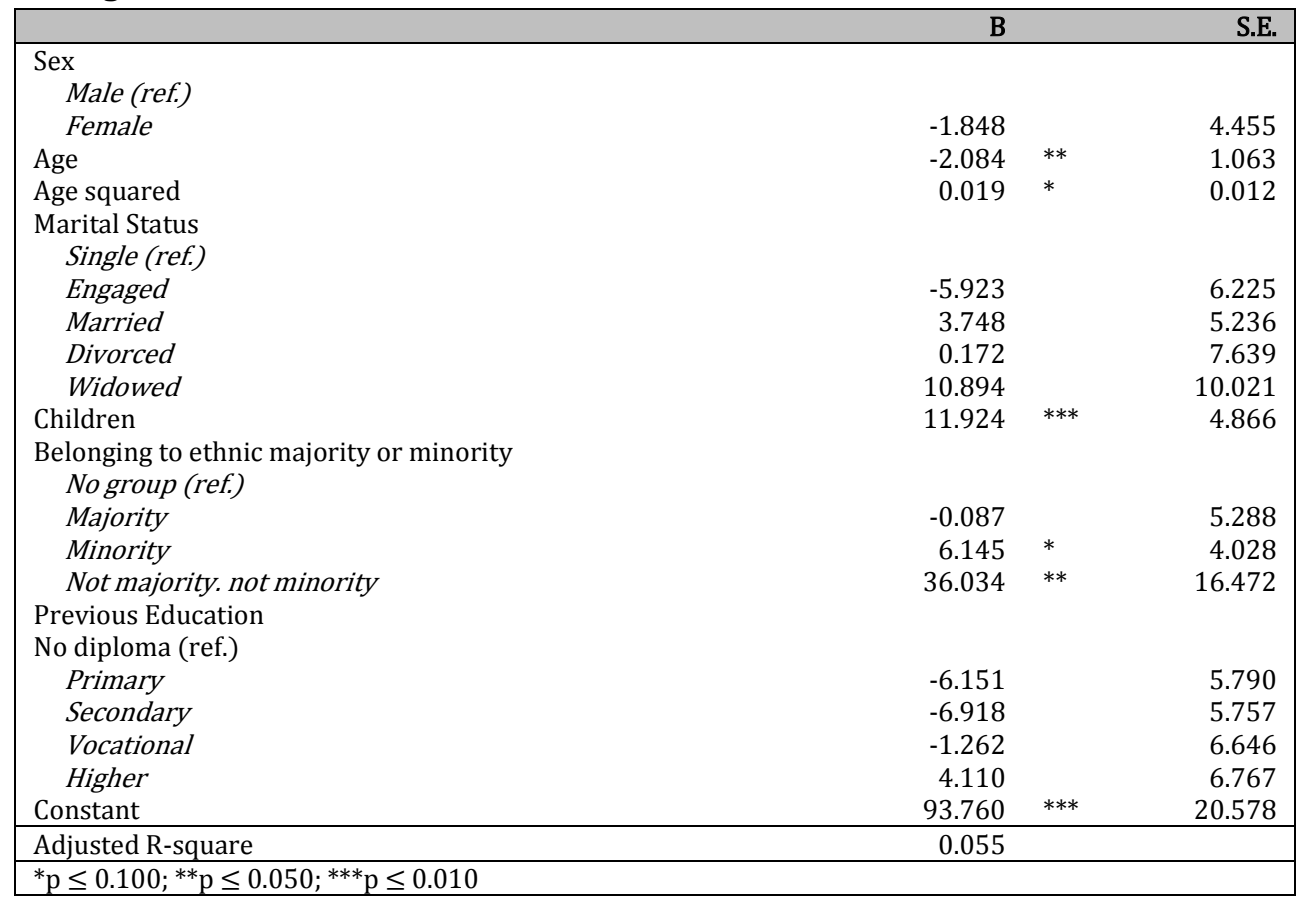

Source: comparative return migration study in six countries, 2007 


\section{2c Regression of social embeddedness on migration cycle}

\begin{tabular}{|c|c|c|c|}
\hline \multirow{2}{*}{ First reason to migrate } & \multicolumn{2}{|l|}{ B } & \multirow[t]{2}{*}{ S.E. } \\
\hline & & & \\
\hline \multicolumn{4}{|l|}{ Economic reasons (ref.) } \\
\hline Unsafety due to conflict & 4.017 & & 6.042 \\
\hline Personal unsafety due to conflict & -4.123 & & 5.496 \\
\hline Discrimination & -27.233 & $* * *$ & 8.566 \\
\hline Family reunion & 5.803 & & 8.326 \\
\hline Other reasons & 8.178 & $*$ & 6.128 \\
\hline \multicolumn{4}{|l|}{ Expectations of asylum } \\
\hline \multicolumn{4}{|l|}{ Expected permanent asylum (ref.) } \\
\hline No expectations & -3.584 & & 6.157 \\
\hline Expected temporary asylum & 3.748 & & 5.788 \\
\hline Did not apply for asylum & -4.063 & & 10.442 \\
\hline Other expectations & 4.750 & & 11.811 \\
\hline Duration abroad (months) & 0.061 & & 0.055 \\
\hline \multicolumn{4}{|l|}{ Housing security in host country } \\
\hline \multicolumn{4}{|l|}{ Insecure (ref.) } \\
\hline Asylum & 5.685 & & 9.180 \\
\hline Semi-secure & 7.807 & & 9.149 \\
\hline Independent & 5.807 & & 9.478 \\
\hline \multicolumn{4}{|l|}{ Education abroad } \\
\hline \multicolumn{4}{|l|}{ No education (ref.) } \\
\hline Yes & 2.955 & & 4.183 \\
\hline Only language education & -1.990 & & 5.431 \\
\hline Employed abroad & -2.572 & & 4.133 \\
\hline Savings abroad & 6.125 & $*$ & 4.585 \\
\hline Remittances abroad & 1.290 & & 5.158 \\
\hline Contact abroad & 1.296 & & 5.116 \\
\hline Heath abroad & -4.334 & & 7.002 \\
\hline \multicolumn{4}{|l|}{ Legal status at point of return } \\
\hline \multicolumn{4}{|l|}{ Rejected (ref.) } \\
\hline Protection & 4.864 & & 6.131 \\
\hline In asylum procedure & 9.121 & $* *$ & 5.471 \\
\hline Illegal status & 5.775 & & 5.998 \\
\hline Other status & -9.332 & & 12.307 \\
\hline \multicolumn{4}{|l|}{ Reason for return } \\
\hline \multicolumn{4}{|l|}{ Voluntary (ref.) } \\
\hline Forced & -2.669 & & 4.561 \\
\hline Number of years back & -0.430 & & 0.695 \\
\hline Constant & 44.977 & $* * *$ & 13.825 \\
\hline Adjusted R-square & 0.102 & & \\
\hline
\end{tabular}

Source: comparative return migration study in six countries, 2007 


\section{Psychosocial embeddedness: main results}

\begin{tabular}{|c|c|c|c|}
\hline & B & & S.E. \\
\hline \multicolumn{4}{|l|}{ Assistance } \\
\hline Received assistance origin country government & -9.526 & $*$ & 6.324 \\
\hline Received non material information assistance & 4.902 & & 5.796 \\
\hline Assistance post-return NGO & 5.554 & * & 3.559 \\
\hline Assistance post-return government & 13.324 & $* * *$ & 4.799 \\
\hline \multicolumn{4}{|l|}{ Individual characteristics } \\
\hline \multicolumn{4}{|l|}{ Sex } \\
\hline \multicolumn{4}{|l|}{ Male (ref.) } \\
\hline Female & -6.670 & $*$ & 4.268 \\
\hline \multicolumn{4}{|l|}{ Marital Status } \\
\hline \multicolumn{4}{|l|}{ Single (ref.) } \\
\hline Engaged & 11.410 & $* *$ & 5.881 \\
\hline Married & 12.681 & $* * *$ & 3.963 \\
\hline Divorced & 17.167 & $* * *$ & 6.546 \\
\hline Widowed & 8.759 & & 8.364 \\
\hline \multicolumn{4}{|l|}{ Migration cycle } \\
\hline \multicolumn{4}{|l|}{ First reason to migrate } \\
\hline \multicolumn{4}{|l|}{ Economic reasons (ref.) } \\
\hline Unsafety due to conflict & -5.739 & & 4.832 \\
\hline Personal unsafety due to conflict & -20.090 & $* * *$ & 4.732 \\
\hline Discrimination & -29.266 & $* * *$ & 7.399 \\
\hline Family reunion & 15.339 & $* *$ & 8.062 \\
\hline Other reasons & 0.883 & & 5.560 \\
\hline \multicolumn{4}{|l|}{ Expectations of asylum } \\
\hline \multicolumn{4}{|l|}{ Expected permanent asylum (ref.) } \\
\hline No expectations & 14.233 & $* * *$ & 5.444 \\
\hline Expected temporary asylum & 9.149 & $* *$ & 5.094 \\
\hline Did not apply for asylum & 11.078 & & 8.834 \\
\hline Other expectations & 5.588 & & 10.699 \\
\hline \multicolumn{4}{|l|}{ Housing security in host country } \\
\hline \multicolumn{4}{|l|}{ Insecure (ref.) } \\
\hline Asylum & 6.745 & & 8.373 \\
\hline Semi secure & 14.239 & $* *$ & 8.539 \\
\hline Independent & 13.467 & $*$ & 8.616 \\
\hline Savings abroad & 13.472 & $* * *$ & 3.629 \\
\hline Contact abroad & 15.031 & $* * *$ & 4.059 \\
\hline Constant & 18.499 & $* *$ & 11.391 \\
\hline Adjusted R-square & 0.496 & & \\
\hline
\end{tabular}

Source: comparative return migration study in six countries, 2007 
3a Regression of psychological embeddedness on assistance

\begin{tabular}{|c|c|c|c|}
\hline & \multicolumn{2}{|l|}{ B } & S.E. \\
\hline Assisted by NGO & -20.538 & $* * *$ & 7.501 \\
\hline Assisted by host country government & 0.926 & & 6.914 \\
\hline Assisted by origin country government & -2.291 & & 8.143 \\
\hline Assisted by institution & 11.039 & & 11.250 \\
\hline Assisted by family/friends & -7.253 & & 8.544 \\
\hline Received financial assistance & -11.956 & & 11.456 \\
\hline Received assistance in business set up & 5.482 & & 4.835 \\
\hline Received non material labour market assistance & -5.980 & & 5.500 \\
\hline Received non material information assistance & -2.705 & & 8.222 \\
\hline Received psychosocial or medical assistance & -1.536 & & 5.319 \\
\hline Assistance pre-return NGO & -3.256 & & 5.653 \\
\hline Assistance pre-return government & -10.607 & $* *$ & 6.240 \\
\hline Assistance pre-return family/friends & 18.515 & $* * *$ & 5.795 \\
\hline Assistance post-return NGO & 21.605 & $* * *$ & 6.334 \\
\hline Assistance post-return government & 12.898 & $* *$ & 6.527 \\
\hline Assistance post-return family/friends & -2.470 & & 6.476 \\
\hline Constant & 66.550 & $* * *$ & 10.093 \\
\hline Adjusted R-square & 0.121 & & \\
\hline${ }^{*} p \leq 0.100 ;{ }^{* *} p \leq 0.050 ;{ }^{* * *} p \leq 0.010$ & & & \\
\hline
\end{tabular}

Source: comparative return migration study in six countries, 2007

\section{3b Regression of psychological embeddedness on individual characteristics}

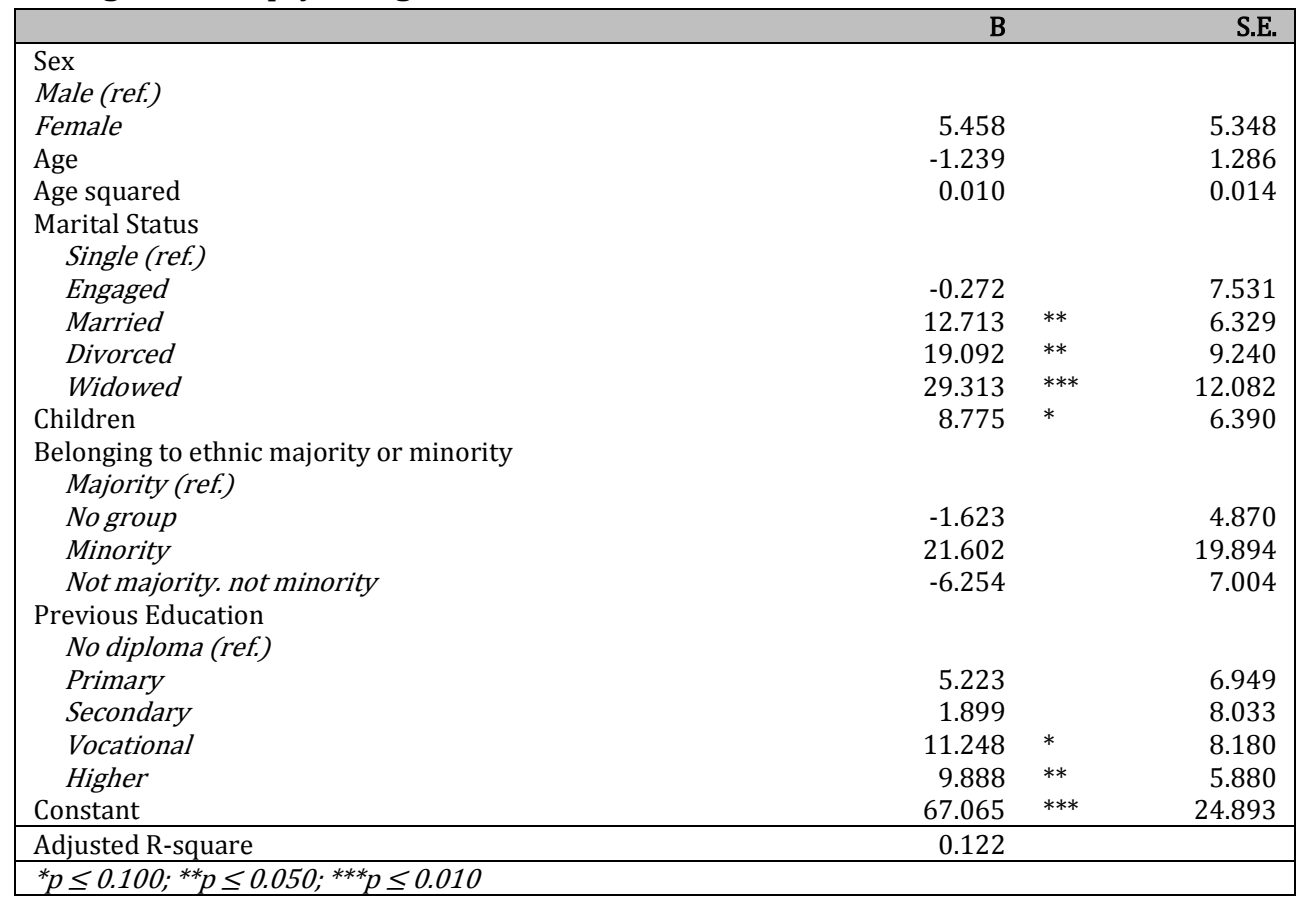

Source: comparative return migration study in six countries, 2007 
3c Regression of psychological embeddedness on migration cycle

\begin{tabular}{|c|c|c|c|}
\hline \multirow{2}{*}{ First reason to migrate } & \multicolumn{2}{|l|}{$\mathrm{B}$} & \multirow[t]{2}{*}{ S.E. } \\
\hline & & & \\
\hline \multicolumn{4}{|l|}{ Economic reasons (ref.) } \\
\hline Unsafety due to conflict & -8.797 & $*$ & 6.047 \\
\hline Personal unsafety due to conflict & -15.901 & $* * *$ & 5.484 \\
\hline Discrimination & -29.024 & $* * *$ & 8.557 \\
\hline Family reunion & 19.451 & $* * *$ & 8.335 \\
\hline Other reasons & 2.136 & & 6.133 \\
\hline \multicolumn{4}{|l|}{ Expectations of asylum } \\
\hline \multicolumn{4}{|l|}{ Expected permanent asylum (ref.) } \\
\hline No expectations & 10.479 & $* *$ & 6.126 \\
\hline Expected temporary asylum & 12.550 & $* *$ & 5.779 \\
\hline Did not apply for asylum & 5.820 & & 10.474 \\
\hline Other expectations & 4.072 & & 11.833 \\
\hline Duration abroad (months) & -0.021 & & 0.055 \\
\hline \multicolumn{4}{|l|}{ Housing security } \\
\hline \multicolumn{4}{|l|}{ Insecure (ref.) } \\
\hline Asylum & -3.579 & & 9.202 \\
\hline Semi-secure & 5.477 & & 9.174 \\
\hline Independent & 1.200 & & 9.506 \\
\hline \multicolumn{4}{|l|}{ Education abroad } \\
\hline \multicolumn{4}{|l|}{ No education (ref.) } \\
\hline Yes & -5.982 & $*$ & 4.196 \\
\hline Only language education & -5.417 & & 5.379 \\
\hline Employed abroad & 5.955 & $*$ & 4.143 \\
\hline Savings abroad & 14.378 & $* * *$ & 4.593 \\
\hline Remittances abroad & -2.590 & & 5.174 \\
\hline Contact abroad & 11.596 & $* * *$ & 5.122 \\
\hline Heath abroad & 0.597 & & 7.024 \\
\hline \multicolumn{4}{|l|}{ Legal status at point of return } \\
\hline \multicolumn{4}{|l|}{ Rejected (ref.) } \\
\hline Protection & -0.531 & & 6.143 \\
\hline In asylum procedure & 1.785 & & 5.467 \\
\hline Illegal status & -0.557 & & 6.017 \\
\hline Other status & -1.100 & & 12.338 \\
\hline \multicolumn{4}{|l|}{ Reason for return } \\
\hline \multicolumn{4}{|l|}{ Voluntary (ref.) } \\
\hline Forced & -5.161 & & 4.574 \\
\hline Number of years back & 0.876 & & 0.697 \\
\hline Constant & 46.965 & $* * *$ & 13.865 \\
\hline Adjusted R-square & 0.453 & & \\
\hline
\end{tabular}

Source: comparative return migration study in six countries, 2007 

I am not a bogus communist whose inner convictions cripple his innate humanity. I am not a Mujahedeen who does Jihad over the property, lives and honour of the people. I am not a Taliban who goes to heaven by blowing himself up.

I am not like any of them. I am alone, I am a human and only human. AHRDO - Infinite Incompleteness. A Documentary Theatre Play, p. 112. 


\section{4}

\section{Afghanistan}

A political history of conflict, migration and return

\subsection{Why Afghanistan as a case study?}

Afghanistan's protracted history of conflict and migration is a relevant case in the study of return migration, development and peace-building, for various reasons. First, the 35-year-long history of Afghan conflict and migration shows how the globally changing political discourses of the past decades have shaped migration strategies (Monsutti 2008). Second, two major trigger events of this shifting discourse, the Cold War and the events of 11 September 2001, played a direct and crucial role in the history of Afghanistan (Turton and Marsden 2002, Stigter 2006). Third, the fact that in 2014 all eyes are again on Afghanistan makes it a relevant and timely case to focus on. This chapter sketches Afghanistan's history of migration, of which the conflict-related migration of the past 35 years is a crucial, but not new or exceptional, episode. It shows that migration to and return from Europe is only a small part of Afghan migration. Last, this chapter looks at prospects for the future of Afghan migration.

\subsection{A political history of conflict, migration and return}

Migration in its various forms has played an essential role throughout the history of Afghanistan, shaping the social and economic fabric of the country in which mobility became a key livelihood strategy (Monsutti 2008). Since early times, migration within and across the borders of Afghanistan has been a common experience for reasons of communication, trade, (seasonal) labour and conflict, establishing ancient transnational networks (Dupree 1975, Stigter 2006, Monsutti 2008, Oeppen 2009). Migration also played an important role during Afghanistan's state-building and modernization period, affecting the events that led to conflict (Rubin 2002, Suhrke 2007). The Afghan conflicts of the last 35 years have further increased the significance of migration on an unprecedented scale (Jazayery 2002, Turton and Marsden 2002, Stigter 2006). The bulk of Afghan migratory movements were within Afghanistan or to the neighbouring countries, while only a fraction reached industrialized states (Jazayery 2002, Stigter 2006). A short political history of Afghan migration is vital for understanding current issues of conflict and migration (Monsutti 2008). 


\subsubsection{State building and migration}

Afghanistan's power structure was created along lines of language, religion and descent, creating a pattern of tribal and ethnic stratification. From the mid-eighteenth century until 1973, Pashtun kings, who belonged to the largest ethnic group, ruled the territories of present-day Afghanistan. Therefore, the members of the royal family, the Muhammadzais, part of the Durrani clan, were at the top of the social hierarchy. Below them came the other Durranis, then the rest of the Pashtuns. After the Pashtuns came the other predominantly Sunni groups, of whom the Persian speaking Tajiks, who were the second largest ethnic group, were most important, because Persian was spoken in the capital Kabul. After that came the Sunni groups who spoke Turkic languages, the Uzbeks and Turkmen. The Shi'a religious minority, mostly belonging to the Hazara ethnic group who were of Mongol or Turkic origin, were at the bottom of the social order (Rubin 2002). Although ethnicity and descent were thus important in the social hierarchy, power was, to an important degree, determined by class. While political leadership was officially in the hands of Pashtuns, a wider urban 'élite', which was multi-ethnic and multi-lingual, was in power (Oeppen 2009). The political influence of Islam was limited and until 1978 religious leaders never ruled the country (Rubin 2002).

Afghanistan's political history is furthermore characterized by dependency relationships with international world powers. The Pashtun kings successfully managed to resist direct colonial rule during two Anglo-Afghan wars in the nineteenth century. However, the British empire still attempted to make Afghanistan a steady buffer state against Russia by making the Pashtun kings dependent on British capital, weapons, education abroad and foreign advisors (Rubin 2002, 279). The availability of external resources for the Afghan state enabled the government to become autonomous from the society under its rule, and decreased the power of the tribes and religious leaders. It also meant, however, that a loss of external resources immediately led to a decay of national rule (Rubin 2002, Oeppen 2009).

From the early twentieth century, Afghan rulers constantly searched for modernization, and migration for higher education became an important instrument of this. Students going abroad for a university education were, in the first place, the children of the 'traditional' élite that is often defined by lineage, such as children of the royal family, or of local political or religious leaders. In addition, the development and growth of secular higher education in the twentieth century led to the growth of a small urban middle class or 'new' élite, who also accessed higher education. However, the job market for educated labour was narrow, and the educated new élite mostly ended up in employment below their level of qualification, which led to frustration (Oeppen 2009).

It is argued that the recurrent periods of conflict that followed can be understood as the by-product of Afghanistan's state-building and modernization process (Rubin 2002, Suhrke 2007, Oeppen 2009). The dependency on external resources and the top-down modernization efforts alienated the urban foreign-educated ruling class from the local population and leadership. This caused a rural-urban divide that can still be felt today and is argued to be, along with class, a more significant societal cleavage than ethnicity (Suhrke 2007, Oeppen 2009). In addition, the new élite's frustration, in combination with their foreign experience and education, made them 
receptive to radical political movements such as Marxism on the one hand and Islamist movements on the other (Majrooh 1990, in Oeppen 2009). The next section describes how this led to conflicts that produced unprecedented levels of migration.

\subsubsection{Conflicts and migration}

Although migration has always been part of Afghan society, 'there is no doubt that refugee migration from 1978 onwards has massively increased the number of Afghans abroad' (Oeppen 2009, 80). 35 years of conflict and disruption in Afghanistan have led to the dispersion of millions of Afghan people around the world. Throughout this time, 'Afghanistan has seen the coming and going of Kings and presidents, mullahs and militias and the world's superpowers' (Özerdem and Sofizada 2006, 80). Responding to changing circumstances, the nature of this conflict-related migration was constantly reshaped (Monsutti 2008).

\section{Escaping communist rule and Cold War violence}

In 1978, the communist People's Democratic Party of Afghanistan (PDPA) came to power through a coup with the help of the Soviet Union. The new regime made unpopular land reforms and usury reform and introduced equal rights for women, which were fiercely contested by the population and the anti-communist parties (Rubin 2002). In 1979, the Soviet Union invaded Afghanistan to counter the resistance to the communist regime and the tensions between Afghan commanders and Soviet advisors (Collins 2011). Detentions and executions of non-leftist intellectuals led to the first wave of Afghan migration, mainly to Pakistan and Iran (Jazayery 2002). Refugee camps along the Pakistan-Afghanistan border became military bases from which the Mujahedeen, a resistance movement of warlords of different ethnic factions, emerged (Turton and Marsden 2002).

In the light of the Cold War, Afghanistan became a key battlefield in which the conflict was sustained by both superpowers (Cramer and Goodhand 2002, Turton and Marsden 2002, Rubin 2006). For the first time, the Soviet Union had attacked a nation outside the Warsaw pact. ${ }^{1}$ The USA and other Western states actively responded by supporting the Afghan refugees in Pakistan and by funding and arming the anticommunist Mujahedeen in an attempt to weaken the Soviets (Jazayery 2002, Turton and Marsden 2002, Collins 2011). In addition, the Jihad against the atheist communists also attracted financial support and Muslim resistance fighters (including Osama bin Laden) from various countries (Oeppen 2009).

The escalation of fighting throughout the country led to a large outflow of Afghans escaping violence and degraded livelihood opportunities (Stigter 2006). While members of the Afghan élite fled the threat of targeted attacks, the majority of Afghans escaped to avoid conscription into the National Army or being caught in cross-fire between the Mujahedeen and the army and Soviet forces (Oeppen 2009).

\footnotetext{
1 The Warsaw pact was a collective defence treaty among eight communist states who pledged the mutual defence of any member who was attacked.
} 


\section{Escaping civil war under Mujahedeen rule}

The Soviet Union withdrew from Afghanistan in 1989 following internal policy changes that led to the end of the Cold War. The Afghan communist regime managed to resist the Mujahedeen for three more years. In 1992, when, following the demise of the Soviet Union, the financial support to the communist regime fully came to an end, the Mujahedeen finally conquered Kabul and the communist regime fell (Cramer and Goodhand 2002, Rubin 2002). While this prompted a return of over two million Afghans who had originally fled the communist government, it also provoked a new flow of out-migration of those who were associated, or were perceived to be associated, with the PDPA regime (Oeppen 2009).

With the end of the Cold War, the great world powers lost interest in the Afghan conflict. After seizing power and removing the common enemy, the Mujahedeen fell apart and the war mutated from a Cold War conflict into a regionalized civil war along ethnic, religious and tribal lines (Koser and Black 1999, Cramer and Goodhand 2002, Rubin 2002, Oeppen 2009). The lack of superpower support and the fragmentation of authority led to an expanding war economy. Warlords increasingly had to generate resources locally and regionally to fund their military activities, which led to lawlessness and banditry (Cramer and Goodhand 2002, Oeppen 2009).

This was a period of fluid movements of both return and out-migration (Marsden 1999). Following the developments in world politics, the international community scaled down its large-scale protection schemes for refugees in the neighbouring countries, resulting in a less friendly attitude in Pakistan and Iran towards Afghan refugees (Turton and Marsden 2002, Blitz, Sales, and Marzano 2005, Stigter 2006, Collins 2011, Abbasi-Shavazi et al. 2012). By 1997 an estimated four million Afghans had returned from Pakistan and Iran (Stigter 2006). At the same time, the escalation of violence led to new out-migration as the fighting moved across Afghanistan. The refugee population exceeded six million people in the early 1990s (Marsden 1999, Jazayery 2002).

\section{Escaping ethnic cleansing and violence under Taliban rule}

The continued civil conflict was the breeding ground for the rise of the Taliban in 1994. Rubin argues that Pashtuns who grew up in Pakistani refugee camps with no notion of peace lost track of their tribal roots, which made them receptive to the influence of religious figures and Islamic schools in Pakistani refugee camps. Based on a combination of their interpretations of Shari'a (Islamic) law and Pashtunwali, the tribal code of the Pashtuns, the Taliban emerged as an anti-modern fundamentalist Islamic movement (Rubin 2002, Oeppen 2009).

Financially and ideologically supported by Pakistan and by Islamic fundamentalists from the Middle East, including Al Qaeda (Oeppen 2009, Collins 2011), the Taliban rapidly took control of many areas in Afghanistan. They were initially welcomed by the local population as they established relative security. The Taliban captured Kabul in 1996. They installed Shari'a law in an extremely strict manner, including strict rules on women's behaviour, entertainment and dress for men and women, using torture, amputations and executions as punishment for disobeying the strict decrees. In addition, the Shi'a Hazara population were persecuted for their religious background (Oeppen 2009, Collins 2011). 
The violent conquest of the country, in addition to the ethnic cleansing of the Hazara and the harsh regime, and together with a prolonged drought between 1998 and 2001, caused a new outflow of migrants (Jazayery 2002, Turton and Marsden 2002, Collins 2011). By the year 2000, the number of refugees was again at the level of six million, in addition to one million internally displaced people (IDPs). Despite the growing outflow of Afghans, the international community kept scaling down its assistance to refugees in the neighbouring countries. This caused 'asylum fatigue' and a hardening of the attitude of these host countries towards their refugee populations (Turton and Marsden 2002, Özerdem and Sofizada 2006).

The Afghan conflict again became the centre of the world's attention when Al Qaeda, led by Osama bin Laden, declared war on the Western world and eventually attacked the United States on 11 September 2001. After the refusal of Afghanistan to hand over Osama bin Laden, the United States launched their 'War on Terror' against Al Qaeda and the Taliban. Together with the Mujahedeen, Tajiks, Hazara, Uzbeks and anti-Taliban Pashtun tribes organized in the Northern Alliance, the United States began to fight the Taliban in Afghanistan (Oeppen 2009, Collins 2011). The fighting and coalition bombings again resulted in an outflow of Afghans, including those associated with the Taliban regime (Jazayery 2002, Oeppen 2009). The Taliban was chased from Kabul after one week, although the leadership of both Al Qaeda and the Taliban managed to escape into Pakistan (Collins 2011).

\section{Post-Taliban reconstruction, return and migration}

Three decades of violence destroyed and reshaped the Afghan infrastructure at all levels. While Afghanistan was historically a weak central state, the structures that did exist were destroyed during these conflicts (Rubin 2002). Physically, agriculture and homes were destroyed several times. Economically, there was widespread poverty, unemployment and a lack of goods and production. Socially, entire generations grew up in exile without the notion of peace or security (Rubin 2006, Suhrke 2007, Cramer and Goodhand 2002, Özerdem and Sofizada 2006). In addition to destroying previously existing institutions and economies, decades of war also created an informal wartime economy and institutions (Cramer and Goodhand 2002). The production of poppy and opium and the affiliated drug trade was a dominant contributor to this 'black economy', which was controlled by warlords and therefore caused insecurity (Özerdem and Sofizada 2006).

In the post-Taliban era, the international community launched a highly ambitious reconstruction programme, which required radical social change. Like many previous post-war reconstruction programmes, it was not merely about repairing what was broken, but entailed a broader modernization and state-building project. This included the installation of the rule of law, human rights and gender issues, liberal democratic institutions and elections, civil society and an open economy with marketbased economic growth and access to education (Cramer and Goodhand 2002, Özerdem and Sofizada 2006, Suhrke 2007). Local ownership of these programmes was, according to Suhrke, characterized by 'their' ownership of 'our' ideas (Suhrke 2007).

It has been argued that the post-conflict modernization programmes gave little attention to, and were sometimes inherently contradictory to, the complex historical processes in which the Afghan conflicts are rooted. Previous negative effects of 
modernization efforts on social cohesion, the aversion to foreign influence, as well as the war and post-war legacy, have been insufficiently taken into account. Therefore, after the first enthusiasm about the fall of the Taliban, the reconstruction efforts met a great deal of resistance (Cramer and Goodhand 2002, Suhrke 2007). In addition, after the initial high profile military operation, there was too little attention and money available to provide support to a country that was socio-economically and institutionally ruined (Collins 2011, Özerdem and Sofizada 2006). It has been argued that international aid supporting the state capacity will simply reproduce a state incapable of managing the conflicting interests passed down the generations and reshaped by two decades of war' (Cramer and Goodhand 2002, 906).

Immediately after the fall of the Taliban, the international community initiated the largest repatriation operation of refugees in UNHCR's history, displayed in Figure 4.1 (Jazayery 2002, Blitz, Sales, and Marzano 2005, Monsutti 2008). The repatriation of refugees was seen by the international community as the ultimate proof of peace and return to 'normality'. It was intended to send a powerful message to the world that the intervention of the Western allies in Afghanistan and the War on Terror in general was successful (Turton and Marsden 2002, Black and Gent 2006, Stigter 2006). The significance of this political message was evident in the build up to the war in Iraq, which started in 2003 (Blitz, Sales, and Marzano 2005). Between March and September 2002, the UNHCR assisted the return of approximately 1.7 million Afghans from Pakistan and Iran (Turton and Marsden 2002, Özerdem and Sofizada 2006). In total, more than five million Afghan refugees returned, mostly from Pakistan and Iran, as well as another half a million IDPs (Kronenfeld 2008, Monsutti 2008, Oeppen 2009). There was a mixture of reasons for this high return rate: returnees' confidence in the new government, expectations for the reconstruction of the country that were raised by the international community, and the deterioration of living conditions in Pakistan and Iran (Turton and Marsden 2002, Stigter 2006, Monsutti 2008). Approximately 30 per cent of returnees settled in Kabul (Blitz, Sales, and Marzano 2005, Stigter 2006).

Figure 4.1 Annual return to Afghanistan 2002-2013

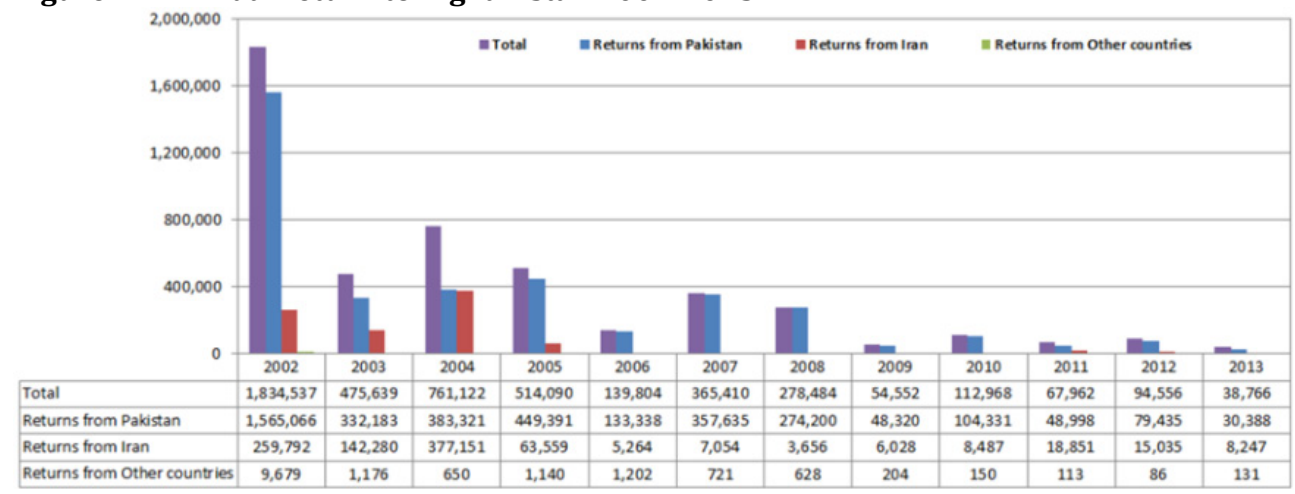

Source: UNHCR Afghanistan fact sheet 2013

Analysts have, in retrospect, suggested that the high levels of return were too fast for Afghanistan's absorption capacity and that return should not have been the priority at this time (Stigter 2006). The massive repatriation of Afghans into the war-torn, 
drought-stricken and infrastructurally weak societies of return caused widespread unrest (Turton and Marsden 2002, Özerdem and Sofizada 2006). The extra demand for housing, employment and water, which were already insufficient for the local population, put a burden on the economy (Stigter 2006). In the absence of a wellcoordinated repatriation strategy by the international community (Özerdem and Sofizada 2006) and sustainable solutions for these returnees, many Afghans became displaced again, either within or outside Afghanistan. Others chose not to return but instead stayed illegally in their host country or relocated to other countries (Monsutti 2008, Koser and Schmeidl 2009).

Security remained the largest issue in Afghanistan because of the continued presence of warlords and the return of the Taliban from Pakistan (Özerdem and Sofizada 2006, Collins 2011). After some years of relative peace, the Taliban launched an insurgency to regain power, to free Afghanistan from infidel forces and influence, and to re-establish an Islamic state (Collins 2011). With the Taliban re-emerging, and the war between the international troops and the Afghan army and the Taliban continuing, new migration flows emerged (Blitz, Sales, and Marzano 2005).

\subsubsection{Legacy of three decades of conflict and future mobility perspectives}

Mobility has been a fundamental coping and survival strategy throughout the history of Afghanistan and increasingly over the past 35 years. An estimated ten million Afghans - one third of the population - have been refugees at least once during this period (Koser 2014), while it has been stated that more than half of the Afghan population has migrated at some point since the conflict started (Harpviken 2009, in Oeppen 2009). Figure 4.2 shows the dispersion of Afghans across the globe in $2000 / 2001$.

The nature of Afghan migration has constantly been reshaped in response to changing circumstances of violence and insecurity and livelihood opportunities (Monsutti 2008, Koser 2014). Emerging from the prior existence of migration and transnational networks in the region, mobility and transnational networks became increasingly significant as a key survival strategy for individuals and families. Migration has become a highly organized system embedded in the Afghan way of life, and continues to be an encompassing aspect of the cultural, social and economic fabric (Jazayery 2002, Turton and Marsden 2002, Stigter 2006, Monsutti 2008).

The Afghan migration context is an example of how dichotomies in migration policy do not match reality. The boundaries between forced and voluntary migration are blurred because the strategies and motivations of people labelled as 'refugees' or 'economic migrants' are often similar (Monsutti 2008). In addition, the migration of Afghans is neither permanent nor temporary, and return movement does not imply the end of displacement. Rather than seeing Afghan migration as a linear process, it is more appropriate to speak of a recurrent multidirectional movement. This continual movement makes Afghan society a genuinely transnational community (Monsutti 2008). 


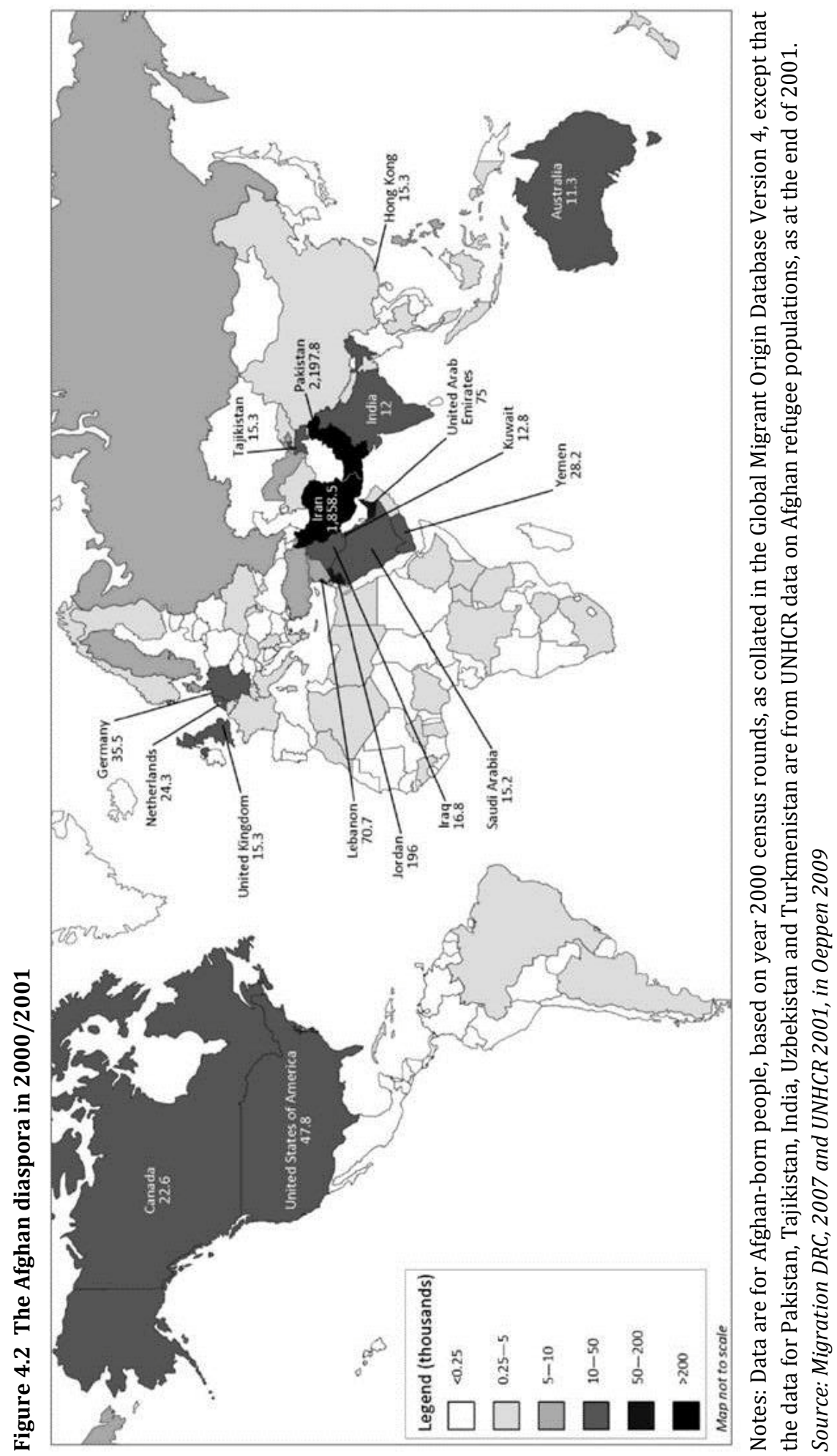


The context of the long-standing history and widespread scale of Afghan migration is likely to shape future mobility outcomes, although their scale and direction is not entirely predictable. The vulnerability of displaced Afghans makes them susceptible to the effects of growing insecurity. In addition, those who have become familiar with migration as a coping strategy are likely to turn to migration in response to insecurity, stress or threat. Alternatively, Afghan returnees who have invested significant resources after returning may be unwilling to move again unless this is absolutely unavoidable (Koser 2014).

The year 2014 is expected to be a turning point in the history of Afghanistan. The planned withdrawal of the international military forces is only one aspect of a multidimensional transition period that includes security, political, and economic challenges, which are inextricably linked (Koser 2014). Political challenges include the widespread corruption; the need for a political leadership that can attract a wide base of support; the prospect of the Taliban regaining power and joining the political process; and anti-government elements taking over the de facto control of many regions in Afghanistan. Economic concerns include an expected faltering of business confidence and employment opportunities after the withdrawal of military troops and the international community. The expected decrease in economic growth after 2014 may be reinforced by the political dimension, if international aid becomes conditional on improvements in governance (Koser 2014). These transitions are likely to affect levels of insecurity and to have an impact on the livelihoods of many Afghans with regard to food security, poverty and access to education and health care (UNHCR 2013c, Koser 2014).

Most analysts consider the most plausible scenarios to be either a return to civil war or a violent take-over by one of the parties, while a movement towards peace does not seem to be a realistic option (UNHCR 2013c, Wolf 2013). However, there is also resistance from within Afghanistan to the idea that the country's fate is (again) in the hands of the international community. In addition, it is argued that too much progress has been made to be reversed so easily (Koser 2014). At the time of writing, although the relative peace in which the presidential elections were conducted, and both the remaining candidates stress their desire to come through the process in a peaceful way, disputes over results and ways to move forward, and growing impatience among the population, cause continued uncertainty over the future of Afghanistan (Van Bijlert 2014). Sharpened by international attention on 2014, public perceptions of security are pessimistic and create self-fulfilling prophecies that influence migration decision-making today (UNHCR 2013c, Koser 2014).

These contrasting developments in Afghan mobility are reflected in current statistics, as is shown in Table 4.1. An estimated one in thirty Afghans is internally displaced. Urbanization has resulted in approximately 30 per cent of all Afghans now living in urban areas, and 60-70 per cent of these live in informal settlements (Koser 2014). More than one in eight Afghans currently lives outside the country, as a refugee, an undocumented migrant, or as part of the wider diaspora (Koser 2014). Return to Afghanistan is ongoing. While spontaneous and assisted return from the neighbouring countries is decreasing, the asylum fatigue of Pakistan and Iran has led these long-time host countries to increase the pressure to return and to put in motion deportation programmes. In addition, Afghanistan remains one of the top five countries of origin for IOM Assisted Voluntary Return and Reintegration (AVRR) 
programmes from the industrialized countries (Koser 2014). Also, there is still a steady number of Afghans in industrialized countries who are applying for IOM's Return of Qualified Afghans programme for temporary placements (Koser 2014).

Table 4.1 Afghan mobility: Afghan IDPs, migrants and returnees ${ }^{1}$

\begin{tabular}{|llr|}
\hline Category & Type & Number \\
\hline Total displacement & IDPs & $486,298^{1}$ \\
& Refugees & $2,586,200^{1}$ \\
& In Pakistan and Iran & $2,400,000^{2}$ \\
\hline Current return & From Pakistan and Iran 2012-2013 & $414,033^{2}$ \\
& Return assisted by IOM 2002-2011 & $13,201^{3}$ \\
& Temporary return of Qualified Afghans via & $1,400^{3}$ \\
& IOM 2002-2011 & $52,074^{1}$ \\
\hline Current out-migration & Pending asylum seekers world-wide 2012 & \\
\hline
\end{tabular}

Sources: 1. UNHCR Statistical Yearbook 2012 (2013b); 2. Koser (2014), data from 2013; 3. IOM website (accessed 2014)

While return is ongoing, the number of asylum claims in industrialized countries is again increasing, after having decreased in the first years of the post-Taliban era (see Table 4.2, Monsutti 2008, Oeppen 2009, UNHCR 2013c). With 36,600 new asylum claims, Afghanistan was in 2012 the most important source country for people seeking asylum in the industrialized countries (UNHCR 2013c). This is due both to the onward migration of Afghans who are put under pressure to leave Iran and Pakistan but prefer to go further afield rather than to take the risk of returning to Afghanistan, and to new out-migration from Afghanistan (Koser 2014). A specific group of new refugees are Afghans who have worked with the international community after 2002 and who fear reprisals by the Taliban (UNHCR 2013c).

Table 4.2 Total asylum claims of Afghans in 44 industrialized countries

\begin{tabular}{|l|rrrrr|}
\hline Year & 2002 & 2007 & 2008 & 2011 & 2012 \\
\hline No. of asylum claims & 29,400 & 10,000 & 18,500 & 35,700 & 36,600 \\
\hline
\end{tabular}

Source: UNHCR (2009), UNHCR (2013c)

\subsection{Afghan migration to Europe}

While 96 per cent of all Afghan migrants live in Pakistan or Iran, a small minority of Afghan migrants who had the necessary financial and social capital travelled further afield to industrialized countries (Oeppen 2009). An estimated 300,000 Afghans are currently settled in the United States, at least 150,000 in the United Arab Emirates, perhaps 125,000 in Germany, and smaller numbers in Canada, Australia and across other European countries (Koser 2014). Despite their small number, their composition and the expected better conditions of life in exile makes them a politically and economically significant factor in relation to hopes and plans for development and

\footnotetext{
${ }^{1}$ Note that all statistics on migration and refugees are estimates, as it is generally very hard to calculate the actual numbers.
} 
peace-building (Zunzer 2004, Koser 2014). Afghans in the industrialized countries have sent remittances and invested in Afghanistan on a significant scale, and have contributed significantly to political processes over the past 12 years (Koser 2014). However, what is often overlooked is that the group of Afghan migrants in Europe is also heterogeneous in terms of background, skills and reasons for migration, as well as in terms of their living conditions in the host country (Jazayery 2002, RostamiPovey 2007).

\subsubsection{Composition of the group of Afghans in Europe}

In the early phases of the conflict in the 1980s and 1990s, the majority of Afghans who migrated to Europe, North America or Australia were members of the Afghan educated élite from the upper and middle urban classes (Monsutti 2008, Oeppen 2009). Those with the greatest resources were able to travel directly to the United States or Europe. For as long as Afghanistan was a central stage in the Cold War, Afghans arriving early in industrialized countries were often given refugee status and eventually citizenship. Although the Afghan élite is a minority of the total Afghan refugee population, it is therefore overrepresented in the industrialized countries (Oeppen 2009). The significance and status of the wider Afghan diaspora became visible during the Bonn peace talks after the fall of the Taliban. The members of the Afghan diaspora from the USA and Europe were very active participants in the conference and represented three-quarters of the administration of the interim government (Jazayery 2002, Zunzer 2004). In addition, the Bonn conference showed that the diaspora was split into various groups, representing different political agendas, divided along historical and ethnic lines. These factions illustrate how divisions continued to exist among the diaspora (Van Hear 2003).

In the later phases of the conflict, people of more modest descent also found their way to the industrialized countries. As the conflict continued and policies in the neighbouring countries became harsher and directed towards return, Afghans who did not want to return and who had the opportunity also migrated onward to European countries (Turton and Marsden 2002, Koser 2014). Other people who escaped from Afghanistan during the rule of the Taliban and as a result of the War on Terror also moved onwards to Europe (Monsutti 2008). However, Afghans who arrived in Europe during and after the second half of the 1990s encountered increasingly restricted immigration and asylum policies and were often given temporary status (Jazayery 2002, Turton and Marsden 2002, see chapter 5 and Van Houte, Siegel, and Davids Forthcoming). In addition, after the events of 11 September 2001 a general rise in xenophobia was used to justify stricter migration policies (Hyndman 2012).

Soon after the overthrow of the Taliban in 2002, host governments considered the situation in Afghanistan to be safe enough for Afghan asylum seekers to return (Jazayery 2002, Turton and Marsden 2002). European states withdrew temporary asylum statuses, became stricter about incoming asylum seekers and initiated the return of Afghans in 'voluntary' return programmes (IRIN 2011). As a response, many Afghans who arrive now decide not to apply for asylum and instead choose to live 
illegally in Europe, even if they would be eligible to be recognized as refugees (Schuster 2011).

\subsubsection{Experiences of return from Europe to Afghanistan}

After the overthrow of the Taliban in 2002, return 'home' to Afghanistan was not always a self-evident move. Although migrants from conflict areas often relate a large part of their identity to a territorially defined homeland, this is also an ambivalent relationship. The discrepancy between the idealized country of origin and the reality of a war-torn society makes it difficult to decide to return (Al-Ali, Black, and Koser 2001, Jazayery 2002, Braakman 2005, Braakman and Schlenkhoff 2007). In this study, many respondents referred to this ambivalent relationship by talking about Afghanistan in reference to its 'dust'. On the one hand, this had an affectionate connotation, referring to the 'soil' from which they were born, which is common in the vocabulary of exile (see Lyons 2004). On the other hand, 'dust' can also be seen as a metaphor for the messy lack of transparency of the conflict-ridden country (Blitz, Sales, and Marzano 2005).

The overthrow of the Taliban in 2002 sparked a movement of Afghans returning both voluntarily and involuntarily from Europe, and both these groups are included in this study. There has not been much research done previously on either group, although the group of failed asylum seekers was included in the comparative return migration study (see chapter 3). In addition, Afghan migrants' views on return and temporary return visits have also been studied to some extent. Insights coming forward from these studies will be discussed below.

Return with permanent legal status in the host country

Among Afghan refugees, although the 'myth of return', defined as the conviction that exile is temporary and that they will eventually return home (Zetter 1999) is a lively concept, actual return is generally considered to be unrealistic. The differences in quality of life in a war-torn society, including the aspects of security, economy, education, and limited opportunities and freedoms for women and children, prevent them from returning (Jazayery 2002, Braakman 2005). In addition to general political and security issues, they fear being targeted as supposedly rich returnees from the West (Braakman 2005). Also, they feel that the responsibility of taking care of family members through remittances requires them to stay (Jazayery 2002). Last, if migrants had had to sell their homes or borrow money for the journey, they would thus return indebted, and they would consider this as an obstruction to their return (Braakman 2005).

Rather than a real intention to return, the myth of return and the nostalgic longing for the homeland is, for many Afghan migrants, a coping mechanism. It helps them to deal with their problems in exile, such as their perceived lower status and social isolation (Zetter 1999, Carling 2004, Blitz, Sales, and Marzano 2005, Braakman and Schlenkhoff 2007, King, Christou, and Teerling 2011). Many Afghans dream about returning to Afghanistan in their old age. This postponed intention to return reconciles economic issues (being able to live off their pension or savings), security 
issues (the hope that by then the conflict will have been solved) and the freedom to dream about return without having to make concrete plans yet (Braakman 2005).

After 2002, the greater ability to travel to Afghanistan did lead to a growing number of Afghans who temporarily returned to invest in and contribute to the reconstruction of the country (Jazayery 2002). In particular, migrants with social networks in and material ties, such as land or property, to Afghanistan were more likely to have a desire to return (Blitz, Sales, and Marzano 2005, Braakman 2005). Some took advantage of job opportunities in the reconstruction, interpreting and consultancy sectors or sold or rented family properties (Oeppen 2009). Others returned through the IOM's temporary return programmes, to work in temporary placements in positions within ministries, government institutions and the private sector (IOM website). According to Braakman, these return visits made many Afghan migrants realize how different they had become from the local Afghan population. This realization cured many of them of the idea of going back permanently, and helped them to feel more at peace about settling in their countries in Europe (Braakman and Schlenkhoff 2007).

A small proportion of these voluntary returnees stayed in Afghanistan for the longer term (Blitz, Sales, and Marzano 2005, Braakman 2005, Oeppen 2009). Most of them are adult males who had a concrete prospect of re-establishing themselves socially and professionally through, for example, a high profile job offer (Braakman 2005, Blitz, Sales, and Marzano 2005). Younger Afghan migrants also felt a sense of responsibility to 'give something back' by returning and helping to rebuild their country (Blitz, Sales, and Marzano 2005). However, they only did so if they had the ability to leave Afghanistan again if things did not work out (Blitz, Sales, and Marzano 2005, Braakman 2005, Braakman and Schlenkhoff 2007).

\section{Return without permanent legal status in the host country}

For Afghans who do not have a permanent legal status and face the threat of forced repatriation, returning to Afghanistan is, according to Braakman, 'not a dream but a nightmare' (Braakman 2005, 140). Her study among Afghans in Hamburg, Germany showed that while migrants with permanent status present an idealized image of the home country, exactly the opposite happens when they feel there is a risk of being forcibly sent back. They talk negatively of their country of origin and, instead, their dream is to be able to stay in their host country. "The fear of an irreversible expulsion seems to hamper and suppress nostalgic positive feelings towards Afghanistan' (Braakman 2005, 112). In addition, the migrants who did not have permanent legal status were also the ones who had left late and had had more traumatic experiences of the war (Braakman 2005, Braakman and Schlenkhoff 2007). In Blitz et al.'s study among Afghans in the UK, these migrants often indicated that it was too soon to return permanently, that the country was in an ongoing conflict and that they feared antagonism towards them. They indicated that they had found a home in the UK and no longer wanted to return (Blitz, Sales, and Marzano 2005).

Nevertheless, after 2002, European states initiated the return of Afghans without permanent legal status in 'voluntary' return programmes (IRIN 2011, Schuster 2011). The comparative study on return migration (see chapter 3 ) showed the main factors affecting the post-return embeddedness of these returnees in Afghanistan. Economically, like the rest of the population, unemployment rates among returnees 
were high and their income was insecure. House ownership decreased from 18 per cent before migration to 0 per cent after return. While the majority were young, unmarried men and had lived with their families before migration, people who had owned a house had usually sold it to pay for the journey. People in insecure economic situations also worried more about their physical safety (De Bree 2008, see also Strand et al. 2008). Only a few return migrants were relatively successful economically and as a result had fewer difficulties in terms of socio-cultural and psychosocial embeddedness (De Bree 2008).

All returnees in the 2007 study were reunited with their relatives and strongly relied on the support of their relatives for housing and food. Many returnees also received remittances from relatives still living abroad. Nevertheless, having returned empty-handed and dependent on relatives also damaged their status, which made them feel like failures. Having returned from the West, they mentioned distrust and ambivalent attitudes towards them. While their cultural and religious integrity was questioned, they also felt that people were interested in their money, which led them to hide the fact that they had returned from Europe. The return migration was mentioned as a traumatic experience. Despite the restricted living conditions while abroad, many returnees kept idealizing their host countries and 89 per cent of all respondents said they would re-emigrate if they could (De Bree 2008).

Factors that affected post-return embeddedness were personal background and the migration experience. Class, often corresponding to strong networks, access to capital, influential networks and higher education, positively related to economic embeddedness (De Bree 2008). The extent to which a returnee had managed to send remittances or bring back savings upon return to invest in the social network positively related to his or her embeddedness on all dimensions. Living in asylum centres without being able to work, leading to a failure to meet the expectations of the social network in the country of origin that remittances would be sent, had a negative influence on embeddedness upon return. For this reason, financial assistance provided by return organizations was used to invest in the social network by buying presents and paying for celebrations. Return assistance did not, however, have a significant effect on post-return embeddedness (De Bree 2008).

\subsection{Conclusion}

This chapter has summarized the complicated history of Afghan migration that goes beyond the recent conflicts or the European perspective. Afghanistan's protracted history of conflict and migration within the context of two of the world's major political events of recent decades, the Cold War and the War on Terror, is a relevant case in the study of return migration, development and peace-building. Afghanistan's long term and massive refugee crisis shows the changes of the political discourses over the past three decades from protection to return. These developments dramatically changed the circumstances for Afghan migrants in both neighbouring countries and countries further afield.

The conflict and migration movements of the past 35 years have shaped Afghanistan's reality of today and produced a long-term multi-layered and diverse Afghan diaspora. Migration has become a key survival and livelihood strategy in the 
Afghan way of life, taking place under constantly changing circumstances (Turton and Marsden 2002, Monsutti 2008). Return migration represents a new phase in the long, dynamic and ongoing transnational history of Afghanistan, and takes place in the context of a general mistrust of modernization and foreign influence, an explosive prospect for the future and ongoing out-migration. A crucial new episode in Afghanistan's history is being written as we speak. In the coming months, the economic and political challenges of this transition year, and how these affect migration movements, will surface. Whatever the outcome of this transition period, this chapter has highlighted that migration will certainly continue to play a crucial role in Afghan history (Stigter 2006, Monsutti 2008). 
Who would want to stay? In a place where you are never welcomed, only tolerated. Just tolerated. (...) it drags you in and suddenly you are unable to return.

Zadie Smith - White Teeth, p. 407. 


\section{Meanings of and motivations for return}

Deconstructing the complexity of voluntary and involuntary return

\subsection{Introduction 1}

The motivation for return migration is, more than return assistance, of crucial importance for post-return embeddedness, which is defined as an individual's identification with and participation in one or multiple spaces of belonging (chapter 3, see also Van Houte and Davids 2008, Ruben, Van Houte, and Davids 2009). However, the understanding of return motivation is blurred by political discourses, resulting in a confusing vocabulary and an unsatisfactory dichotomy between voluntary and involuntary return (see Chimni 2000). Analysing the complex meanings of and motivations for return can contribute to an understanding of why return assistance and policies fail and of how the needs and the potential of returnees can be better anticipated through improved policies (Castles 2007).

The end of the Cold War marked a change of discourse in respect of migrants arriving in industrialized countries from conflict areas. Once accepting refugees from rival regimes had lost its ideological or geopolitical value (Chimni 2000), immigration policies changed from protection and integration to containment and return (Koser and Black 1999, Turton and Marsden 2002, Blitz, Sales, and Marzano 2005, Black and Gent 2006, Collins 2011). In this changing political discourse, return 'home' to a sedentary way of life as the natural and desirable state of being increasingly came to be portrayed as a basic human right for refugees (Koser and Black 1999, Chimni 2000, Bakewell 2008). Since the early 1990s, the UNHCR and other international bodies have promoted and facilitated return as the most desirable of all solutions for displaced people (Malkki 1992, Stein and Cuny 1994, Hammond 1999, Zetter 1999, Omata 2013). In practice, however, a strong interest in the return of unwanted migrants has led host countries to plan for their return, with financial inducements or the threat of deportation, much sooner than the migrants themselves would have done. It has therefore been argued that 'voluntary' return programmes come from the realization by governments that they are less costly and politically less painful than enforced removal (Stein and Cuny 1994, Black and Gent 2006, Blitz, Sales, and Marzano 2005).

\footnotetext{
1 This chapter is based on: Van Houte, Marieke, Melissa Siegel, and Tine Davids. Forthcoming. "Deconstructing the Meanings of and Motivations for Return: An Afghan Case Study." (currently under review).
} 
Within this discourse, the distinction between voluntary and involuntary return became based on the use of physical force, in which any non-deported return is considered as 'voluntary'. In addition, the different stakes in the political discourse have led to confusing and inadequate terminologies that have lost much of their logical meaning. For example, the IOM distinguishes between non-mandatory and mandatory voluntary return (Beltman 2012). These politically motivated dichotomies of voluntary and involuntary return do not reflect the diversity of migratory phenomena and behaviours (Koser and Black 1999, Tsuda 1999, King 2012).

In addition to policy, research has also insufficiently addressed the complexity of return migration, for two reasons. First, policy-oriented research often follows bureaucratic definitions for pragmatic reasons. By following these narrowly oriented frameworks, researchers are, however, limited in their ability to discover the meanings and contradictions of return (Hammond 1999, Castles 2003). Second, migration research has historically made a clear distinction between forced and voluntary migration. Research on forced migration from conflict affected countries has focused on the structural forces of migration, which 'assume[d] away the agency of migrants, (...) casting them as victims who need assistance' (Bakewell 2008). However, there is a growing acknowledgement of the fact that all migration, even when taking place under immediate threats to security, involves both choices and constraints. This understanding blurs the conceptual boundaries between voluntary and involuntary mobility (Stein and Cuny 1994, Bakewell 2008, Lubkemann 2008, Monsutti 2008, Hyndman 2012, King 2012).

There is a need for theoretical approaches and analytical tools that can encompass the complex decision-making processes of migration and return migration (Al-Ali, Black, and Koser 2001, Carling 2002, Cassarino 2004, Castles 2007, Bakewell 2010, Omata 2013). This chapter proposes an encompassing analytical framework to deconstruct the unsatisfactory dichotomy between voluntary and involuntary return. The framework recognizes the act of migration and return as a process that takes place under different structural circumstances, with different capacities and desires, creating different levels of agency (Cassarino 2004, Castles 2007, Bakewell 2010). As an analytical tool, it has the potential to be used to study any context of migration and non-migration, in any degree of (in)voluntariness, and in changing circumstances.

I then use the framework on a case study of 35 Afghan return migrants from Europe. ${ }^{2}$ Afghanistan's 35 year-old conflict and massive refugee crisis is a relevant case that shows the changes in the political discourses over the last three decades from protection to return (Jazayery 2002, Stigter 2006, Monsutti 2008). The Afghan case also shows how migratory movements have become included in livelihood strategies in continuously changing circumstances, leading to different migration experiences (Monsutti 2008).

The study took an emic approach to the narratives of returnees that incorporated their own meanings of return (Koser and Black 1999). The complex and sometimes seemingly contradictory narratives of the returnees are discussed to show patterns of structure, agency, desire and capacity and subtexts of mobility and security. Concluding, while pleading that the complexities of return be taken into account, I

\footnotetext{
${ }^{2}$ Chapter 2 describes the methodologies used in this study.
} 
propose to centralize post-return mobility as an indicator for voluntary or involuntary return.

\subsection{Structure and agency, capacities and desires in return}

Two types of theoretical discussions that have tried to address the complexity of migration and return are discussed here: the distinction between structure and agency on the one hand, and desires and capacity on the other. Thereafter, I propose a new analytical framework that combines these two approaches.

\subsubsection{Structure and agency}

Several authors argue that any theoretical account of international migration must include a treatment of the interaction between structure and agency (Castles 2007, Bakewell 2010). Structure is an important concept in the social sciences, and highlights the fact that people's actions do not occur in a vacuum but are embedded in structures (Sewell 1992, Hitlin and Elder 2007). Structures include forces that are external to and impact on people, such as institutional, economic, social and cultural systems (Giddens 1984, in Sewell 1992) that can be at macro, meso and micro levels (Sewell 1992, Castles 2007). I will here focus on Sewell's (1992) interpretation of Giddens' structuration theory; Giddens argues that structures can be divided into 'schemas' and 'resources'. Schemas are implicit rules and procedures that are applied in social life. They do not concretely exist in particular practices or in any particular location in space and time but instead come about from the enactment of social life, such as political ideologies or norms and value systems. On the other hand, 'resources' are the more concrete manifestations and consequences of the enactment of schemas. They can be anything human or non-human that can serve as a source of power in social interactions, such as knowledge, sayings or texts, and are unevenly distributed among people (Sewell 1992).

Agency captures the notion that human action is not just determined by structures, but that humans have a certain degree of choice and control over their social relations and actions within these structures (Sewell 1992, Hitlin and Elder 2007). It is argued that all people have agency, since 'however unequally resources may be distributed, some measures of both human and non-human resources are controlled by all members of society, no matter how destitute and oppressed' (Sewell 1992, 10). The self-reflective beliefs we have about our abilities and capacities (our self-efficacy) are analytically separate from our actual capacity for acting. Self-efficacy is argued to be the central aspect of agency, since actors with a self-perception of agency are more likely to persevere in the face of problems, and develop a sense of personal empowerment (Hitlin and Elder 2007). Agency may therefore be defined as the actor's self-perception of the capacity to achieve his or her desires (Bakewell 2010), which helps people to survive and cope in specific situations of change or crisis (Castles 2007).

It is argued that the more actors are embedded in structures, the more they have the agency to apply them creatively to unfamiliar, contradictory or otherwise 
problematic situations. This implies that actors have the ability to change structures to some degree (Sewell 1992, Emirbayer and Mische 1998). Structures are therefore dual in the sense that they not only define the boundaries of agency, but they are also shaped by agency (Giddens 1984, in King 2012, Sewell 1992). In this way, structures not only put constraints on human actions, but also enable them (Sewell 1992). The fact that schemas are, by definition, subject to change or extension means that the agency to enact these schemas is not entirely predictable and that the effect of these actions on the resources of the actors is never quite certain (Sewell 1992).

Despite the logic of the interplay between structure and agency, the concepts have proved slippery and abstract and are often difficult to apply to empirical research (Hitlin and Elder 2007) or to inspire systematic analysis (Emirbayer and Mische 1998). Authors have therefore addressed the need for more practical analytical tools to study the phenomena of transnationalism and migration, which is discussed below.

\subsubsection{Desire and capacity}

In order to be able to investigate the dynamics of transnationalism, migration and non-migration empirically, several authors have introduced models that capture an analytical distinction between what people want to do and what they are able to do. This distinction touches upon the structure-agency divide, but makes it more tangible and observable in daily life. Al-Ali, Black and Koser (2001) introduce the distinction between actors' capacities or abilities, and actors' desire or willingness, to engage in transnational activities. They show these dynamics of transnationalism on different dimensions (institutional, economic, cultural and social). This provides a framework for a detailed analysis of transnational activities, including changes that may occur in each of these categories, and enables the identification of obstacles and opportunities for policy interventions (Al-Ali, Black, and Koser 2001).

While Al Ali et al. look at transnational activities in general, Carling (2002) and De Haas (2010) have developed models to analyse migration. Carling's model distinguishes between people's aspiration to migrate and their ability to do so. He stresses that the observation that all migration involves both choices and constraints can incorporate the analysis of migration and non-migration, including involuntary immobility (Carling 2002). Similarly, De Haas sees people's propensity to migrate as a function of aspirations and abilities, as part of a wider model with which he analyses the relationship between migration and development (De Haas 2010).

Finally, Cassarino has developed a model specifically for return, distinguishing between willingness and readiness, which together create the preparedness to return. Cassarino's model takes into account the fact that return is not only a voluntary act, and it can incorporate the analysis of a wide variety of migrants, including economic, skilled, unskilled and forced migrants. The model therefore enables an analysis of return that goes beyond dichotomies of success and failure (Cassarino 2004).

These four models of desire and capacity and their equivalents have both advantages and disadvantages compared to the agency-structure model. Unlike the abstract concepts of agency and structure, these models provide straightforward frameworks that enable empirical analysis on transnationalism, migration and return. 
However, although structural economic, political and social contextual factors are recognized as influencing capacities and desires, they remain largely outside these models and most authors do not elaborate on their influence. De Haas' model is the only one that includes structural factors in a more encompassing model (De Haas 2010). In addition, some of these models lead to deterministic frameworks that take away the richness of the duality that is displayed in the agency-structure debate. For example, Carling's model results in different 'modes of migration' (Carling 2002), and Cassarino's model ends with a framework in which returnees of a certain background are likely to have a certain migration outcome (Cassarino 2004). Although empirically valid in their respective case studies, such frameworks close the doors on a more encompassing analysis of migration.

\subsubsection{Towards a comprehensive framework}

Models of agency and structure on the one hand, and of desires and capacities on the other, capture similar but distinct processes in an individual's room for manoeuvre. Figure 5.1 presents a comprehensive framework, which combines the strengths of both models and makes up for their weaknesses in the analysis of the meanings of and motivations for migration.

Figure 5.1 Interplay between structure, agency, desire and capacity

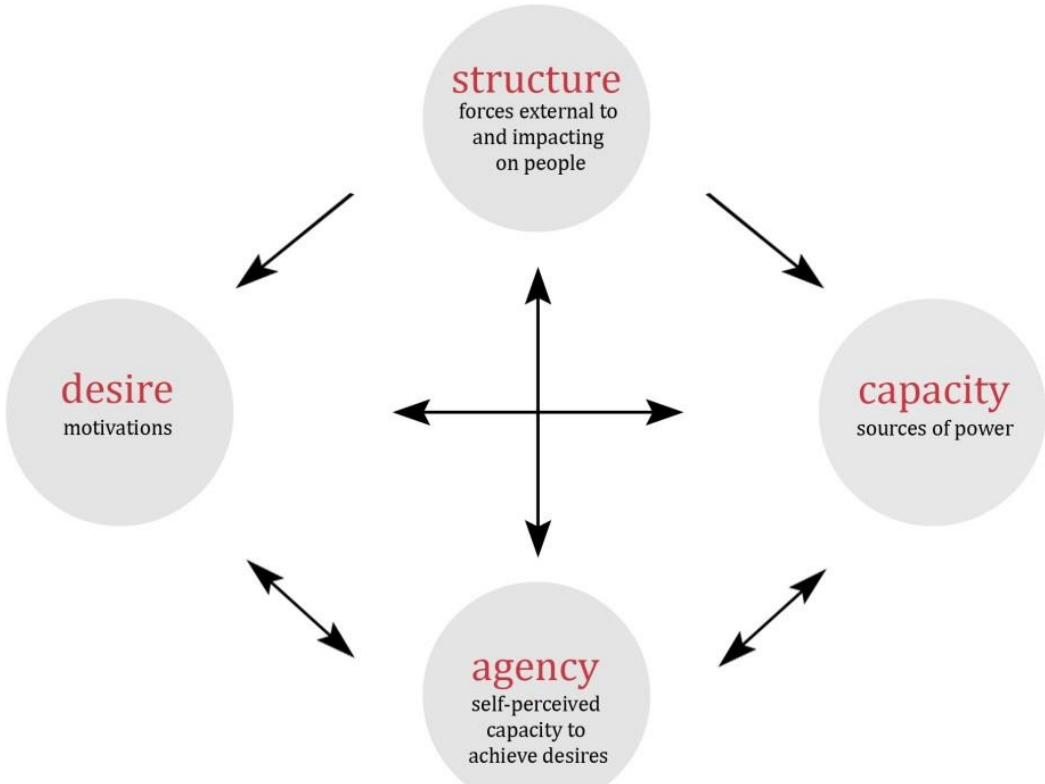

This framework adds an intermediate step of desires and capacities between structure and agency. Structures (defined as the implicit forces that are external to and have an impact on people) affect both an individual's capacities (defined as the human and non-human resources that can serve as a source of power for the actor) 
and his or her desires (defined as intentions or motivations to act), which are in turn interrelated. Agency (defined as an actor's self-perception of the capacity to achieve his or her desires) is determined by these desires and capacities, and is both shaped by and shapes structure.

The framework has the potential form the basis for studies on any context of migration and non-migration, in any degree of (in)voluntariness and in changing circumstances. In addition, the interplay between structure, capacity, desire and agency takes place on all dimensions of embeddedness. Table 5.1 shows examples of structures, capacities and desires on each dimension of embeddedness. The overview is based on the literature reviewed above, but does not claim to be exhaustive.

Table 5.1 Structures, capacities and desires on each dimension of embeddedness

\begin{tabular}{|c|c|c|c|}
\hline & Structures & Capacities & Desires \\
\hline Institutional & 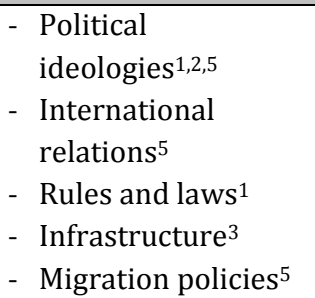 & $\begin{array}{l}\text { - Institutional } \\
\text { membership }{ }^{1} \\
\text { - Legal status }{ }^{4,5,6} \\
\text { - Access to force } 4 \\
\text { - Criminal record }{ }^{5} \\
\text { - Documentation (visa, } \\
\text { passport, contract) }{ }^{5}\end{array}$ & $\begin{array}{l}\text { - Living in safety } \\
\text { - Freedom of } \\
\text { movement }^{5} \\
\text { - Securing legal status } 6 \\
\text { - Political change in } \\
\text { country of origin } 4,6\end{array}$ \\
\hline Economic & 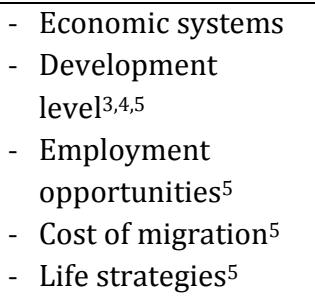 & $\begin{array}{l}\text { - Knowledge }{ }^{1} \\
\text { - Physical strength } 1,5 \\
\text { - Employment } 5 \\
\text { - Education \& skills }{ }^{4,5} \\
\text { - Assets \& savings } 1,5,6 \\
\text { - Experience } 2,4,5\end{array}$ & $\begin{array}{l}\text { - Material aspirations } 2,5 \\
\text { - Career ambitions } \\
\text {-Self-supportiveness/ } \\
\text { independence }^{6}\end{array}$ \\
\hline Social & $\begin{array}{l}\text { - } \text { Perception of } \\
\text { migrants } \\
\text { - } \text { Migration pressure }^{5} \\
\text { - } \text { Discrimination } \\
\text { - } \text { Gender norms }^{5} \\
\text { - } \text { Class }^{2}\end{array}$ & $\begin{array}{l}\text { - Networks }{ }^{5,6} \\
\text { - Obligations \& } \\
\text { commitments }^{1,5} \\
\text { - Social status } \\
\text { - Communication \& } \\
\text { information } 5 \\
\text { - Sex }\end{array}$ & $\begin{array}{l}\text {-Support } \\
\text { - } \text { Respect }^{5} \\
\text {-Status } \\
\text {-Access to } \\
\text { information }^{6} \\
\text {-Equality }\end{array}$ \\
\hline Cultural & $\begin{array}{l}\text { - } \text { Norms and values }^{1} \\
\text { - } \text { Religion }^{1} \\
\text { - } \text { Language }^{1,2} \\
\text { - } \text { Tradition }^{2} \\
\text { - } \\
\text { Ethnicity } \\
\text { - } \\
\text { Migration ethos } 5\end{array}$ & $\begin{array}{l}\text { - } \text { Texts }^{1} \\
\text { - } \text { Taste }^{2} \\
\text { - Risk aversiveness } \\
\text { - Creativity } \\
\text { - Views about } \\
\text { migration }^{5}\end{array}$ & $\begin{array}{l}\text { - Inclusion } 6 \\
\text { - Freedom of } \\
\text { expression } \\
\text { - Life in dignity }{ }^{1,6} \\
\text { - Religious freedom } 1,6\end{array}$ \\
\hline
\end{tabular}

Sources: 1. Sewell (1992); 2. Emirbayer and Mische (1998); 3. De Haas (2010); 4. Cassarino (2004); 5. Carling (2002); 6. Al-Ali, Black, and Koser (2001)

Although the concepts may partially overlap in reality, they each have their own analytical value and it seems helpful to distinguish between these four elements. An example can show how these interrelated elements can be taken into account. On the institutional level, a relevant structure that is external to and has an impact on an 
individual migrant's life may be the political ideologies towards foreigners and migration policies. These structures partly shape the migrant's capacities or sources of power since, for example, they determine the likelihood of obtaining legal status. Structures also shape desires, or motivations to act, which are in turn interlinked with capacities: a restrictive legal system may shape a person's desire to obtain legal status in order to have freedom of movement. The extent to which a migrant is able to match desires with capacity can be seen as agency. The agency of people can, in turn, shape structures. For example, when migrants come up with new ways to obtain legal status or enter the country, a structural response might be to toughen immigration and border controls. After giving a general account of the relevant structural realities in which Afghan returnees from European host countries were embedded, I will discuss how structures, desires, capacities and agency interrelate in narratives of return.

\subsection{Structural reality of Afghan conflict and migration}

The Afghan conflicts of the last 35 years have caused Afghans to leave the country on an unprecedentedly large scale in different 'waves' of migration (Jazayery 2002, Stigter 2006). In 1979, the Soviet Union invaded Afghanistan to support the Afghan communist regime (Collins 2011), sparking a first wave of out-migration of Afghans who fled in reaction to the detentions and executions of non-leftist intellectuals (Jazayery 2002). In 1992, three years after the Soviet Union had withdrawn, the Afghan communist regime was overthrown by the Mujahedeen. These early phases of the conflict caused an outflow of refugee members of the Afghan élite who were affiliated with the pre-communist or communist regime and feared reprisals. Those with the greatest resources were able to travel directly to the United States or Europe. As long as Afghanistan was a central stage in the Cold War, these Afghan early arrivals in industrialized countries were often given refugee status and, eventually, citizenship (Oeppen 2009).

After seizing power, the several ethnic factions of the Mujahedeen fell apart in civil war. The escalation of violence led to new movements of refugees escaping generalized and ethnic violence as the fighting moved across Afghanistan. The refugee population exceeded six million people in the early 1990s (Marsden 1999, Jazayery 2002, Oeppen 2009). The continued civil conflict was the breeding ground for the rise of the Taliban in 1994 (Collins 2011). The violent conquest of the country and the harsh regime imposed by the Taliban, the ethnic cleansing of the Hazara population who were being persecuted for their Shi'a background, and the prolonged drought between 1998 and 2001 caused another outflow of migrants (Jazayery 2002, Turton and Marsden 2002, Collins 2011). By the year 2000, there were again six million Afghan refugees (Turton and Marsden 2002, Özerdem and Sofizada 2006).

Following the changing political discourse after the end of the Cold War, the international community started to scale down their schemes to protect refugees in the neighbouring countries, and shifted their attention towards repatriation (Turton and Marsden 2002, Blitz, Sales, and Marzano 2005, Collins 2011, Abbasi-Shavazi et al. 2012). Many Afghans who did not want to return, and who had the opportunity, migrated onwards to European countries (Turton and Marsden 2002). However, Afghans who arrived in Europe during and after the second half of the 1990s also 
encountered increasingly restricted immigration and asylum policies (Hyndman 2012).

The Afghan conflict again became the centre of the world's attention when Al Qaeda, led by Osama bin Laden, declared war on the Western world and eventually attacked the United States on 11 September 2001. After the refusal of Afghanistan to hand over Osama bin Laden, the United States launched their 'War on Terror' against Al Qaeda and the Taliban. The fighting and coalition bombings again resulted in an outflow of Afghans, including those associated with the Taliban regime (Jazayery 2002, Oeppen 2009).

After the overthrow of the Taliban in 2002, the largest repatriation operation of refugees in the UNHCR's history took place. However, return 'home' to Afghanistan was not self-evident (Jazayery 2002, Blitz, Sales, and Marzano 2005, Monsutti 2008). Although migrants from conflict areas often relate a large part of their identity to a territorially defined homeland, this is also an ambivalent relationship. The discrepancy between the idealized country of origin and the reality of a war-torn society makes it difficult to decide to return (Al-Ali, Black, and Koser 2001, Jazayery 2002, Braakman 2005, Braakman and Schlenkhoff 2007). For migrants to industrialized countries in particular, the financial, physical and emotional investment made when migrating mean that migrants have a lot to lose by going back (Zimmermann 2012).

Nevertheless, Afghans did return from Europe after 2002, under various conditions. First, the greater ability to travel to Afghanistan led to a growing number of Afghans with permanent residence status who were willing to return to invest in and contribute to the reconstruction of the country (Jazayery 2002). While most of them returned temporarily to work in the reconstruction, interpreting and consultancy sectors and to sell or rent family properties, a small proportion of these returnees stayed in Afghanistan for a longer term (Blitz, Sales, and Marzano 2005, Braakman 2005, Oeppen 2009). Second, after the events of 11 September 2001, a general rise in xenophobia led to stricter migration policies (Koser and Black 1999, Hyndman 2012, Castles, De Haas, and Miller 2014, 6). European states withdrew temporary asylum statuses, became stricter about incoming asylum seekers and initiated the return of Afghans without permanent legal status in 'voluntary' return programmes (IRIN 2011, Schuster 2011).

The structural reality of Afghan migration has arguably made legal status an important factor in the shaping of migrants' (transnational) behaviour, including return (Al-Ali, Black, and Koser 2001, Bloch 2008, Brees 2010). First, legal status makes access to industrialized countries a scarce resource (Carling 2004). While people with a secure status can easily leave the host country, as they have the confidence that re-emigration is possible if things do not work out, those without legal status are more reluctant to leave, as it is both costly and risky to re-emigrate (Carling 2004, Blitz, Sales, and Marzano 2005, Jones 2011). Second, migrants who do not have legal status may not return as many are unable to accumulate sufficient possessions for a secure and successful return as a result of economic and social vulnerability (Dolan 1999). For these reasons, legal status will be highlighted in the analysis as a central structural force affecting returnees. 


\subsection{Narratives of return}

This section explores the interaction between structure, capacity, desire and the variations of agency in the narratives of returnees with and without permanent legal status in the host country.

\subsubsection{Return without permanent legal status in the host country}

The most negative account of return comes from Wasim. ${ }^{3}$ After Wasim left Afghanistan as a consequence of both the conflict and of a conflict in his own family, it took him about eight years to reach the United Kingdom. Even though he did not manage to obtain refugee status, he did not want to return to Afghanistan. He said that he brought a knife with him each time he had to report to the police, with the intention of committing suicide if he was going to be deported. However, he said that when that day came, he did not have his knife with him. Instead, he physically resisted his deportation so strongly that his arm was broken in the struggle. The interview took place five years after his return to Afghanistan from the UK. When asked how he was doing, he started crying and explained how his life had been miserable since his return. He said that because he was illiterate and had received no education, his only economic opportunity was to do manual labour, which the lasting effects of his broken arm had made impossible.

Wasim's narrative can be deconstructed into different components: the structural reality was that the asylum policy of the UK did not give him an asylum status and that the authorities wanted him to leave after the fall of the Taliban. However, the lack of prospects for a life in Afghanistan and the enormous financial and temporal investment he had made to reach Europe gave him a strong desire to stay in the UK, as was pointed out by Zimmerman (2012). His capacity to prevent his return was limited to physical resistance: he fought with the police when he was deported. The agency he had over his return was minimal, and his alternatives were extreme: instead of being deported to Afghanistan, he could have gone into hiding from the police, or committed suicide, as he had intended. The fact that he did not do this was, however macabre, a choice he made. Nevertheless, his strong desire to stay, the lack of capacity to do so, and the sudden and enforced conditions of deportation made his return a disempowering experience. Wasim displayed his broken arm as a symbol of how his return continued to affect his life negatively. Other Afghans who were deported told narratives with a similar, resentful tone.

The story of Areef shows a returnee with a similar structural reality, who produced a very different narrative as a result of the interplay between desires and capacities. Areef left Afghanistan at the age of 16, with the intention of finding a means to support his family who were in a deprived situation because of the war. He travelled for two years before he reached the Netherlands. He applied for asylum three times and lived in the Netherlands for ten years, with four of these years being

\footnotetext{
3 To protect the privacy of the participants in this study, all names are pseudonyms. For the same reason, details such as towns or countries of residence are sometimes intentionally unspecified.
} 
spent as an undocumented migrant under difficult circumstances. Although he tried everything to stay, at some point he decided to return. He said:

How long do you want to stay in the Netherlands? You will never get a permanent status. Here, every time I call here, my mother says you have to go back, my father says come back. And I heard my father died. Only then I say OK, I go back to Afghanistan.

- Areef (m, interview, original in Dutch)

Areef's structural reality was that the asylum system did not give him permanent status and he lived as an undocumented migrant. Although he had the capacity to survive in the Netherlands, based on the support he received from NGOs, his desire was not so much survival, but permanent settlement, which would have allowed him to support his family. By highlighting the difficult situation he was in and the social pressure from, but also the good relationship with, his parents, Areef divides the agency over his return between himself, his parents and the host state.

Hamid, who returned before his possibility of staying expired, is a good example of the complexity of return motivations. Below are quotes from an interview with him, in chronological order, which represent a seemingly contradictory narrative.

I was not rejected. I could stay there. But my father was sick and I stay very long time there. And I (was) supposed to come to help my father, to service to my father in the last time of his life and to get his prayer for my life.

(...)

Then when the Taliban collapsed, the Holland government sent some people to me, saying that now the Taliban is not a threat. So you are more than welcome to go back to your country. And they took my passport, they took everything else. And I said OK and I waited waited waited and it continued for about 2.5 years.

(...)

(translator's intervention): He has his passport and it's from 2004-2005 and he says that if there's any chance, you can take it to Holland and if you can renew it, bring it back here and I can go, that would be great.

(...)

Actually it would have been a lot better if I was accepted in Holland but unluckily I could not get the chance. I just missed it somehow. And my friends are still there and they're having a good time. But the thing is that I really like Afghanistan and Afghanistan is a best place for me. I have my family here. I have my relatives, and to be honest, I cannot compare a little dust of Afghanistan, a very unpaved street of Afghanistan to a very beautiful place in Holland. Because this country this is my mother.

(...)

And when I came, I had some money in my pocket that I brought from Holland. And when I came I saw my dad he was really in a terrible situation as he was sick and plus they were renting a house and they didn't pay rent of the house for four months, they were behind for four months.

(...) 
And then everybody encouraged me for taking care of my dad and everybody persuaded me and said now you see you're the older son of your dad and now he sees you here, and now he's no longer sick so. And I was really happy for that.

- Hamid (m, interview, original in Dari, via translator)

Hamid's structural reality was that the asylum policy of the Netherlands did not give him permanent status to stay. Although he still had the capacity to remain in the host country, his temporary ID had already been withdrawn, and he knew that it would be hard to stay in the Netherlands for much longer. Although he had the desire to stay, he also expressed the desire to be in his 'mother' country and to support his parents. On the one hand, his failure to stay in the Netherlands was very disappointing and disempowering to him ('they took my passport, they took everything else'), especially since he felt a relative failure compared to his friends. On the other hand, he still claimed agency over his return by saying that he returned even though he did not have to (yet), because he was needed by his family. By highlighting desires that matched his capacities, he could claim agency and give meaning to his return.

When their legal capacity to stay in the host country was restricted, returnees reprioritized or redefined their desires, stressing cultural and social belonging to their mother country, their family, and their culture, to claim agency over their otherwise undesired return. However, if returnees like Hamid wanted to claim agency over their return, why did he and many other returnees try to open up the possibility of leaving again, in the case of Hamid by asking the researcher to reissue his 'passport'? Several returnees themselves also observed this contradiction:

Those people who are saying that they are really happy being in Afghanistan, and they don't wanna go back. Believe it or not if you gave them their passport and their visa, if their departure is at ten, I'm sure they want to leave at nine.

- Kamal (m, interview, original in Dari, via translator)

The story of Ajmal provides some insights. Like Hamid, he insisted that he had himself decided to return, while it also became clear that he was a rejected asylum seeker. Although he would have liked to build up his life in the Netherlands, he did not have the capacity to find employment within the structural reality of his status as an asylum seeker, which made him feel as if he was wasting his time. Upon return, he rebuilt a successful business and was able to renovate his house in central Kabul. In this way, he claimed agency over his return by matching his desires and his capacities. However, he also said:

I am happy for my life, I love my country, I love my Afghanistan, my kids, I am here. But in case if there is any problem in the future, we don't know the future, what will happen. If there's something the Holland government could do to help us. Just ideas.

- Ajmal (m, interview, original in Dari, via translator)

Reza, who was deported from the UK, was also able to achieve his desire of becoming a successful businessman after return. Reza explained that with his own construction company he could make more money in Afghanistan than when doing unskilled work in the UK. Nevertheless, Reza explained that he had tried many times to leave 
Afghanistan again. Once he paid a human smuggler to bring his family to Canada, but he was deceived and lost his money. He said:

So many times I try to go back there. (...) Actually, I don't know why I want to go there. (laughs). Back.

- Reza (m, interview, original in English)

While claiming agency over their return, what these returnees were worried about was not being able to leave again. From the structural reality of Afghanistan's unstable political situation and insecure future, an underlying desire for security and mobility emerged. However, the stricter migration and asylum policies decreased their capacities to migrate out of Afghanistan. This inability to match desires and capacities, resulting in involuntary immobility (Carling 2002), caused a lot of unrest and discontent among these returnees, giving them the feeling that they were 'stuck' in a highly explosive environment. Their desire for mobility added a subtext that gave their narratives the seemingly contradictory twists.

\subsubsection{Return with permanent legal status in the host country}

Now consider the case of Besharat. After arriving in the Netherlands with his parents, he obtained refugee status and eventually Dutch citizenship, which gave him every formal rights to participate in society. However, he felt his ambitions were held back by his immigrant background and limited knowledge of the Dutch language. During a visit to Afghanistan, he was offered a job and he stayed. From there he quickly grew to become a successful artist, which he said had always been his dream.

[In the Netherlands] if I told someone I wanted to be [an artist], they said are you crazy, that is so expensive. (...) He said there is no job for you there. Then my dream again went back to the ground.

(...)

And when I know I come back, I feel for the first time that I am out of the gevangenis (jail). (...) All the opportunity you have there (in the Netherlands), everything can be done, security, hospital, beveiliging (security). (...) Here is you have nothing, but still for me, if I was in Holland, (...), I'm sitting in a jail.

- Besharat (m, interview, original in English)

Besharat's story is different from the stories presented above. Although he had the legal capacity to stay, other structural forces hampered his ambitions in the Netherlands. His narrative is typical of Afghans of a higher socio-economic background who had high career ambitions but experienced a glass ceiling in the host country, which they related to discrimination and racism (see Ammassari 2004). Besharat's narrative shows that although the structural reality of the asylum policy worked in his favour, he experienced a force in society that kept the ambitions of immigrants at a low level. Although he had a strong desire to become an artist, he felt that his capacity to break through the stigma of being a foreigner was limited. With his 
narrative of becoming a successful artist, he claimed agency over his return and over his success after return, as a result of his determination.

Eshan, unlike Besharat, did not experience the social-structural glass ceiling. He migrated along with his parents to Germany, obtained refugee status and German citizenship, received a large part of his education there and found a good job. However, after some years he applied for a job in Afghanistan and returned. He explained:

After I finished my studies and all this time I worked, and I was quite bored about everything. And didn't know why (...) I'm not happy because I had everything (...). And then what was still something missing and I was looking for it what can it be, should I change my job, should I change my style, should I change my life, and what's the problem. (...) And then I found out, maybe it's a good thing to go back to my roots and start again as a human being (...) can you live in Afghanistan, it is something for you, do you still identify yourself as an Afghan?

- Eshan (m, interview, original in English)

Eshan's narrative shows that although he had the capacity to lead an economically wealthy life, he also had the desire to find a sense of identity, meaning and belonging, which made him feel depressed. He claimed agency over his return by framing his return to the country of his youth as part of his personal search for his identity.

The stories of Besharat and Eshan show that the decision to stay or move is not only dependent on structural forces such as the legal framework, but can be seen as an effort to match desires and capacities on all dimensions of embeddedness. This effort mainly concerned the economic dimension in the case of Besharat and a cultural dimension in the case of Eshan. In the case of Tareq, who had Dutch citizenship, a good job and a Dutch wife, a change in his social situation after his divorce caused a mismatch in desires and capacities.

It started when my mother-in-law, she was a bit... How should I put it (laughs) she didn't like foreigners. She didn't like them. And after that the case of 11 September. Made it worse. So she tried everything to separate us. And she did it.

- Tareq (m, interview, original in Dutch)

Tareq went on to highlight the structural reality of discrimination and gender norms, which in the juridical aftermath of the divorce made him lose custody over his children. This situation put so much stress on him that he started to develop psychosomatic problems such as a loss of function in his legs. He did not have the legal or social capacity to keep his family together and could not meet the desire to control the situation. On an impulse, he decided to return, claiming full agency over the decision.

I never thought I would come back here. Suddenly I had the thought. You know what, I'll go, see what happens there.

-Tareq 
Tareq followed his impulse to return to Afghanistan, and remarried. However, as the security situation in Afghanistan started deteriorating, he was now thinking of moving again, together with his wife.

The narratives of Eshan, Besharat and Tareq showed that they returned in an effort to match desires and capacities on different dimensions of embeddedness, just like Wasim, Areef, Hamid, Ajmal and Reza. However, unlike the first group, their legal status allowed them to be transnationally mobile, which meant that they had the capacity to leave Afghanistan should the balance between their desires and their capacities change again. This transnational mobility gave these returnees, unlike the other interviewees discussed in the first part, a sense of security and comfort in the highly unstable context of Afghanistan. This mobility proved to be of essential importance in the mind-sets of people, which affected every aspect of life, as will come forward in the next chapters (see also Van Houte, Siegel, and Davids 2014, Van Houte and Davids Forthcoming/b, Van Houte Forthcoming).

\subsection{Discussion and conclusion}

Deconstructing the meanings of and motivations for return

This chapter proposed an encompassing analytical framework to deconstruct return as a complex decision-making process. This framework was intended to find an alternative to the confusing vocabulary and the unsatisfactory dichotomy between voluntary and involuntary return. A better understanding of the meanings of and motivations for return may help in addressing the needs and the potential of returnees, through improved policies. The narrative as a research methodology proved essential in unravelling this complexity and providing an empirically grounded alternative to the policy-oriented categorizations.

The analytical framework builds on earlier theoretical approaches to migration and combines the concepts of structure and agency with the concepts of desire and capacity. Instead of providing deterministic understandings that predict the outcome of migration, this model shows the interaction between structures, capacities, desires and agency, in which all elements may be dynamic or contradictory. Agency can be seen as an actor's effort to match his or her desires and capacities, while being shaped by, and shaping, the structural context. In this mechanism, all actors can display some degree of agency over their actions, either through enhancing their capacities to meet their desires, or by redefining their desires to match their capacities. The framework has the potential to be used in any context of migration and non-migration, in any degree of (in)voluntariness and in changing circumstances. It may be seen as a template of factors that should be taken into account in the study of migration, with the weight and direction of the linkages varying according to the research context.

In the Afghan case study, the analysis centred around the structural reality of changing migration policies and their impact on desires and capacities to return. Migrants who had the capacity to leave early arrived in Europe at a time when the structural reality of migration discourses worked to their advantage. They received permanent status to stay in the host country. Their decision to return was made to match their desires and capacities on the economic, social or cultural dimension. By contrast, people who left later arrived at a time when the structural reality of the 
migration discourse was less advantageous. Consequently, their legal capacity in the host country restricted their possibility of staying there. As a reaction, many returnees redefined their desires by expressing their sense of belonging to their country of origin, their family, and their culture as a justification for return.

This analysis shows that there are no clear-cut boundaries between voluntary and involuntary return (see also Monsutti 2008). Almost no return decision was entirely free, as there were legal constraints, family pressure, economic needs or socio-cultural difficulties at the basis of this decision. Almost no return decision was entirely forced, either, as most people had an alternative, however harsh, to returning. There is therefore a gradual scale, instead, depending on social, economic, institutional and cultural capacities and desires, interacting with structures and leading to different levels of agency over the decision to return.

Nevertheless, the analysis also shows there is a strong empirical difference between the post-return experiences of returnees who have the capacity to be transnationally mobile and the experiences of those who do not. Returnees who were unable to match their desire for mobility with their capacity, because of their lack of legal status in the former host country and its stricter asylum policies, experienced involuntary immobility (Carling 2002). This caused a lot of unrest and discontent, and a feeling that they were 'stuck' in a potentially explosive environment. By contrast, returnees who had permanent legal status in the host country returned while knowing that they would be able to re-emigrate if necessary (Castles and Miller 2009, 68). This continued transnational mobility gave these returnees a crucial sense of security and comfort, and allowed them to take advantage of geographical differences (Carling 2002).

Mobility continues to be an essential desire in the lives of return migrants. I therefore propose to centralize mobility in the analysis of return. At the same time, I propose an alternative working categorization of voluntary and involuntary return. While pleading for the complexities of return to be taken into account, I challenge the current policy-oriented categories that are based on the use of force, by defining the same categories in a more adequate and meaningful way. A distinction that captures the large empirical differences in the post-return experience, which is therefore more relevant for policy and research on migration, should be based on post-return mobility. Practically, this categorization is based on legal status in the host country: the return of migrants with a legal alternative that would allow them to stay permanently in the European country of residence is called voluntary, while return of migrants without such a legal alternative is defined as involuntary. This working categorization will be used throughout the following chapters. 
Why do we feel sorry for people who can't travel? Because, unable to expand externally, they are not able to expand internally either.

Pascal Mercier - Night Train to Lisbon, p. 243. 


\section{6}

\section{The hierarchization of migration}

Return as reinforcement of socio-economic stratification

\subsection{Introduction 1}

In this globalized world, newer, cheaper and more efficient modes of communication and transportation can help to increase the benefits of mobility to migrants who can expand their social environment across borders and maintain ties in multiple social worlds (Vertovec 2001, Carling 2002, Sherrell and Hyndman 2006, Hess 2004, Mazzucato 2008). Maintaining connections to places of origin and destination allows migrants to take advantage of geographical differences and to diversify their opportunities to improve their quality of life, and helps guard against potential downturns (Carling 2002, Horst 2007, Bakewell 2008, Hyndman 2012, Jain 2012, Piotrowski and Tong 2013). In addition, different spaces of embeddedness may serve different purposes in the lives of migrants (Oeppen 2012). This transnationalization of migrants' lives implies that integration into the receiving society and commitment to the origin society are not necessarily substitutes, but can be complements (De Haas 2010, Erdal and Oeppen 2013, Dekker and Siegel 2013).

The 'transnational turn' in migration studies (Faist 2004, Levitt and Sørensen 2004) therefore raised renewed expectations in the debate on the contribution of migrants to development, assuming a number of valuable characteristics of returning migrants from industrialized countries, whether they are economic or conflict-related migrants. In addition to being considered as the better educated, wealthy, entrepreneurial and strongly networked élite, these migrants are expected to benefit from their migration to industrialized countries and to obtain additional knowledge, skills, savings and ideas. Their transnational ties to the country of origin are expected to motivate them to invest these material and immaterial capacities to benefit the development of the country of origin (Al-Ali, Black, and Koser 2001, De Haas 2005, Sherrell and Hyndman 2006, Bloch 2008, Hall and Kostić 2009).

Despite these optimistic expectations, the increasing significance and benefits of transnational ties also highlight mobility and the right or capacity to migrate as an important dimension of inequality and social stratification (Bauman 1998, Portes 1999, Carling 2002, Sørensen, Van Hear, and Engberg-Pedersen 2002, Faist 2008, King 2012, Castles, De Haas, and Miller 2014). Mobility, even wartime migration, is a privilege of a relatively wealthy minority, while many others are not as free to move as they would like (Carling 2002, Bakewell 2008, Lubkemann 2008, King 2012). The study of migrants' contribution to development should therefore recognize the

\footnotetext{
1 This chapter is based on: Van Houte, Marieke, Melissa Siegel, and Tine Davids. 2014. "Return to Afghanistan: Migration as Reinforcement of Socio-economic Stratification." Population, Space and Place. doi: 10.1002/psp.1876.
} 
'hierarchization of the right to migrate' (Castles 2005, 218, Castles, De Haas, and Miller 2014) and 'the power geometries of transnational relations and migratory movements' (King 2012, 144).

Research shows that mobility continues to be an essential desire in the lives of return migrants. The post-return experiences of returnees who have the capacity to be transnationally mobile strongly differ from those who do not have this capacity (see chapter 5 and Van Houte, Siegel, and Davids Forthcoming). Continued transnational mobility allows migrants to take advantage of geographical differences (Carling 2002), while it gives a crucial sense of security to migrants in unstable, 'post-conflict' countries to know that they would be able to re-emigrate if necessary (Castles and Miller 2009). By contrast, returnees who are unable to match their desire for mobility with their capacities, because of their lack of legal status in the former host country and its stricter asylum policies, experience involuntary immobility after return (Carling 2002), and this causes great unrest and discontent and a feeling that they are 'stuck' in a potentially explosive environment. Drawing on an in-depth case study among 35 Afghan returnees from European countries, this chapter explores this new avenue of the hierarchization of mobility. I compare the experiences of voluntary returnees who had a permanent legal status in their European country of residence, and those of involuntary returnees who returned without such status (see chapter 5 and Van Houte, Siegel, and Davids Forthcoming). ${ }^{2}$

In the following, the concept of multidimensional and multi-local embeddedness is introduced as an analytical approach to the multi-sited experience of migration, which merges transnationalism and integration into one analytical framework. After an overview of the history of Afghan migration, this chapter will then explore the interplay between socio-economic background, the migration experience, post-return embeddedness and mobility. I conclude that migration creates unequal opportunities for accumulating skills, knowledge and savings while abroad, which results in strongly differentiated patterns of multi-local embeddedness and transnational mobility. These patterns reinforce previously existing socio-economic stratification and restrict expectations of return migration and development.

\subsection{Multidimensional embeddedness}

The concept of multidimensional embeddedness provides an analytical framework for studying the multi-sited and complex experience of migrants. Embeddedness was introduced in its current meaning by Granovetter (1985), who used it to explain how individual economic actions are embedded in contextual factors such as social networks (see chapter 3 ).

Kloosterman et al. launched the idea of mixed embeddedness, in which the constant interplay between agency and structure is highlighted. While an actor's choices are to some extent determined by structure, actors also have a certain degree of agency over their choices, which can in turn redefine structures (Kloosterman, Van Der Leun, and Rath 1999, Kloosterman 2010). Agency can be seen as an actor's effort to match his or her desires and capacities while being shaped by, and shaping, the

\footnotetext{
${ }^{2}$ Chapter 2 describes the methodologies that were used in this study.
} 
structural context, defined as the forces that are external to and have an impact on people (Portes and Sensenbrenner 1993, see chapter 5 and Van Houte, Siegel, and Davids Forthcoming).

In addition to being mixed, Granovetter's initially narrow understanding of embeddedness was extended into a multidimensional concept by subsequent scholars. Kloosterman et al. highlighted the crucial interplay between the social, economic, institutional and cultural contexts (Kloosterman, Van Der Leun, and Rath 1999, Kloosterman 2010). The identification of different dimensions of embeddedness, although sometimes arbitrary, facilitates the understanding of the complex reality of migrants, who may be embedded strongly on one dimension and less so on another (Levitt 2003, in Oeppen 2009).

In this thesis, I refer to multidimensional embeddedness as an ongoing process of an individual's identification with and participation in one or multiple spaces of belonging. Three important advantages of this approach are highlighted here. First, the multi-local aspect of embeddedness merges concepts of transnationalism and integration into one analytical framework. This enables an understanding that the places of origin, destination, and potential other spaces of embeddedness to which migrants may belong are complements rather than substitutes (De Haas 2010, Dekker and Siegel 2013, Erdal and Oeppen 2013). Second, the multidimensional aspect of embeddedness, including its institutional, economic, social and cultural dimensions, helps to provide a holistic understanding of the individual's life. Third, the mixed approach implies a non-static and non-normative understanding as it does not state how migrants should relate to these structures. Rather, it offers an approach for looking at migrants' self-perceived agency to match their capacities and desires in relation to the structural context.

Table 5.1 of the previous chapter showed examples of the structural forces of embeddedness and the desires and capacities that returnees can have on each dimension of embeddedness (see chapter 5 and Van Houte, Siegel, and Davids Forthcoming). This conceptual framework of multidimensional embeddedness has the potential to compare pre-migration with post-return circumstances as well as migrants with non-migrants. This study will, however, focus on the comparison between different types of returnees in order to explore the heterogeneity amongst them.

Following the line of argument of chapter 5, all returnees who have the permanent legal possibility to stay in the country of destination are considered as voluntary, while all returnees without such a possibility are deemed to be involuntary (see chapter 5 and Van Houte, Siegel, and Davids Forthcoming). In addition, the level of agency can be considered to be significantly different for migrants who were returned with the use of force (Schuster and Majidi 2013). Therefore, a distinction is made between independent involuntary return, including the return of those who participated in AVR programmes, and (physically) forced or deported involuntary return. Table 6.1 shows the number of voluntary and involuntary returnees in the study. 
Table 6.1 Types of return migrants in the case study

\begin{tabular}{|lrrr|}
\hline Type of return & Female & Male & Total \\
\hline Voluntary & 4 & 16 & 20 \\
Involuntary & 0 & 15 & 15 \\
$\quad$ Independent & 0 & 11 & 11 \\
Forced & 0 & 4 & 4 \\
\hline Total & $\mathbf{4}$ & $\mathbf{3 1}$ & $\mathbf{3 5}$ \\
\hline
\end{tabular}

Source: Afghan return migration study, 2012

I will first describe the dynamic structural context within which Afghan migration took place, before discussing the migration experiences of these voluntary and involuntary returnees.

\section{3 'Waves' of Afghan migration}

The Afghan conflicts of the last 35 years have caused several phases of out-migration on an unprecedentedly large scale, which makes Afghanistan a relevant case for studying a diversity of migration experiences (Jazayery 2002, see chapter 4, Stigter 2006). The early phases of the conflict caused the outflow of refugees who belonged to the Afghan élites, consisting of members of the 'traditional' élite that is often defined by lineage, and of the 'new' élites who accessed higher education and were part of a relatively wealthy urban class (Oeppen 2009). In 1979, the Soviet Union invaded Afghanistan to counter the resistance against the Afghan communist regime (Collins 2011). This started a first wave of élite refugees who were members of the precommunist regime or were non-leftist intellectuals escaping detentions and executions (Jazayery 2002). In 1992, three years after the Soviet Union had withdrawn, the Afghan communist regime was overthrown by the Mujahedeen, causing a second wave of élite refugees who were affiliated with the communist regime (Jazayery 2002). Despite their sudden departure with few resources, these élite refugees were often relatively well-equipped to leave the country (Oeppen 2009). Those with the greatest resources were able to travel directly to the United States or Europe, and often received refugee status and permanent residence permits (see chapter 5 and Van Houte, Siegel, and Davids Forthcoming). Although members of the Afghan élite form a minority of the total Afghan refugee population, they are therefore overrepresented in the industrialized countries (Oeppen 2009).

The widespread generalized and ethnic violence of the later phases of the conflict caused massive outflows of migrants. After the Mujahedeen seized power in 1992, its various ethnic factions fell apart in civil war (Marsden 1999). The continued civil conflict was the breeding ground for the rise of the Taliban in 1994. They violently conquered the country and took power in 1996, imposing a harsh regime and carrying out ethnic cleansing of the Shi'a and Hazara population, which coincided with a prolonged drought between 1998 and 2001 (Marsden 1999, Jazayery 2002, Turton and Marsden 2002, Collins 2011). The vast majority of the new refugees who fled the civil conflict, Taliban rule and the drought, could only travel across the border and sought refuge in the neighbouring countries. However, the decrease of international funds after the end of the Cold War caused an increasingly restrictive attitude in 
Pakistan and Iran towards Afghan refugee populations (Turton and Marsden 2002, Blitz, Sales, and Marzano 2005, Collins 2011, Abbasi-Shavazi et al. 2012). A number of Afghans who did not want to return and who had the opportunity to do so decided to move on to European countries (Turton and Marsden 2002). These later arrivals of Afghans to Europe encountered more restricted immigration and asylum policies and were often given temporary asylum status (Jazayery 2002, Turton and Marsden 2002, see also chapter 5 and Van Houte, Siegel, and Davids Forthcoming).

The overthrow of the Taliban in 2002 sparked both voluntary and involuntary return movements of Afghans from Europe. The greater ability to travel to Afghanistan led to a growing number of Afghans with permanent residence status who were willing to return voluntarily to invest in and contribute to the reconstruction of the country (Jazayery 2002). A small proportion of these voluntary returnees stayed in Afghanistan for the longer term (Blitz, Sales, and Marzano 2005, Braakman 2005, Oeppen 2009). In addition, European states withdrew temporary asylum statuses, became stricter towards incoming asylum seekers and initiated the return of Afghans without permanent legal status in 'voluntary' return programmes (IRIN 2011, Schuster 2011). In the next section I will discuss how these differences in socio-economic background and migration experience influence both multidimensional embeddedness and post-return mobility.

\subsection{Voluntary and involuntary return}

This section explores the background and migration experiences of the voluntary and involuntary returnees in this case study. Table 6.2 shows the circumstances in which the respondents departed.

Table 6.2 Circumstances of departure of voluntary and involuntary return migrants

\begin{tabular}{|llrr|}
\hline & & Voluntary & Involuntary \\
\hline Year of birth & Pre-1970 & 1 & 2 \\
& $1970-1980$ & 12 & 11 \\
& $1981-1990$ & 7 & 2 \\
\hline Year of departure & Pre-1994 & 16 & 4 \\
& $1995-2001$ & 4 & 9 \\
& Post-2001 & 0 & 2 \\
\hline Age on departure & $4-13$ & 10 & 0 \\
& $14-20$ & 8 & 6 \\
& $21-30$ & 1 & 7 \\
& $30-50$ & 1 & 2 \\
\hline Means of travel & Unaccompanied & 5 & 15 \\
& With family & 15 & 0 \\
\hline
\end{tabular}

Source: Afghan return migration study, 2012

The majority of voluntary returnees in this study were members of the Afghan élite who were affiliated with the communist regime and migrated in the period around the fall of this regime in 1992. Many had left Afghanistan at a young age, mostly together 
with their parents, while a number of young male Afghan migrants had been sent ahead by their families. Because they were able to leave the country during an early stage of the conflict and because of their high profile, they were often granted refugee status, and eventually citizenship, in the country of residence. These refugees were able to participate in the new society of residence and had access to education, opportunities to learn the language and employment. Although these people described the period of familiarization in the new country as challenging, the experience also gave them an opportunity to increase their capacities, and a strong sense of selfworth. Nevertheless, many of these highly skilled migrants experienced a 'glass ceiling', hindering their careers, which they related to discrimination and racism (Ammassari 2004). In addition, older Afghans who had had an influential position before migration, in particular, often experienced downward socio-economic mobility compared to their élite status in Afghanistan (Oeppen 2009).

Involuntary returnees were of more modest descent and left mainly during the Taliban period. Others had already fled during the civil war and had first resided in Iran or Pakistan before moving on to Europe. All involuntary returnees travelled alone as unaccompanied minors, young adults or married men who had left their families behind in Afghanistan or in the neighbouring countries. Although they were not among the poorest in Afghanistan, they often sold property or borrowed money from relatives to pay for the journey. In addition, many stayed in transit countries for several years to save money for the rest of the trip, and therefore took up to nine years to reach Europe. They arrived in European countries at a later stage, and claimed but never received refugee or permanent asylum status. Their temporary asylum status or undocumented situation restricted their opportunities to enrol in education or improve their language skills. Since they were less well educated and had an insecure legal status, any jobs they found were in the informal sector and were typically low-skilled, so that they did not generate many new skills or savings. Their legal status did not allow them to participate fully in the host society, and their lives there can be described as being in the country, but not of it, as they tended to live apart from the broader destination population (Portes 1999, Piotrowski and Tong 2013).

Table 6.3 shows the post-return circumstances of the returnees in this study. Voluntary returnees returned to Afghanistan at a time when they felt, given their individual circumstances, that this was the best option (Cassarino 2004). The foreign aid industry and the commercial opportunities in a country where everything needed to be rebuilt after decades of conflict offered them the opportunity to take highly skilled jobs or start their own businesses that earning money from funds provided by the international community. These were highly desirable jobs considering the high expatriate salaries and the opportunity to work in the Afghan context with international colleagues. In this way, although much had changed since their departure, the returnees could reclaim meaningful and prestigious positions upon return and find themselves again at the upper end of the social ladder. This contrasted pleasantly with their moderate position in their Western European countries of residence. Issues with regard to the reason for migration, such as political disputes, were remarkably absent from these returnees' narratives. Voluntary returnees who were single or had left their spouses in Europe lived with other returnees or independently. Returnees who were married left their families in the European 
country and supported them with cash flows that have been called reverse remittances (Mazzucato 2011). A minority of voluntary returnees married after return and lived with their spouses.

Table 6.3 Post-return circumstances of voluntary and involuntary return migrants

\begin{tabular}{|c|c|c|c|}
\hline & & Voluntary & Involuntary \\
\hline \multirow{3}{*}{$\begin{array}{l}\text { Year of } \\
\text { (first) } \\
\text { return }\end{array}$} & $2002-2007$ & 8 & 11 \\
\hline & $2008-2010$ & 11 & 2 \\
\hline & $2011-2012$ & 1 & 2 \\
\hline \multirow[t]{7}{*}{ Occupation } & Private business owner & 8 & 3 \\
\hline & International organization & 6 & 1 \\
\hline & Afghan government & 2 & 0 \\
\hline & Afghan NGO & 2 & 0 \\
\hline & Low-skilled employee or self-employed & 0 & 8 \\
\hline & Unemployed & 0 & 3 \\
\hline & Unclear & 2 & 0 \\
\hline \multirow[t]{3}{*}{ Housing } & Shared house with returnees/guesthouse & 7 & 0 \\
\hline & With family & 9 & 14 \\
\hline & Alone & 4 & 1 \\
\hline \multirow{4}{*}{$\begin{array}{l}\text { Marital } \\
\text { status }\end{array}$} & Single & 9 & 0 \\
\hline & Married or relationship, spouse in Europe & 7 & 0 \\
\hline & Married pre-migration, living with spouse & 0 & 4 \\
\hline & Married post-return, living with spouse & 4 & 11 \\
\hline
\end{tabular}

Source: Afghan return migration study, 2012

In contrast to voluntary return, involuntary return felt like a step back rather than an improvement. If involuntary returnees succeeded economically, this was despite rather than because of their time abroad. They were often in low-skilled and unstable jobs, were informally self-employed or were unemployed. While they had already had less well-established networks than the élite returnees, they lost the networks they used to have and were therefore at a disadvantage compared to a large and equally skilled workforce. In addition, they felt that the working circumstances for low-skilled labour were worse than in the European host countries. Only a few involuntary returnees managed to find low-skilled employment within civil or military international organizations. Finally, large parts of their previous savings and belongings had been used to pay for the journey and they had not been able to build these up again. Their weak economic and institutional embeddedness made them feel unprotected from generalized violence, and put them in dependent relationships with their relatives. Their migration experience felt like a waste of time and money. Although they were not among the poorest within the Afghan society before migration, their migration experiences often left them impoverished and frustrated. Involuntary returnees mostly lived with their spouses and other relatives, and they were all married in Afghanistan either pre-migration or after return.

To illustrate and explore the different types of return further, two cases that are representative of the voluntary and the involuntary returnees in this study will now be discussed. The first case, that of Nadir, is representative of the experience of the members of the Afghan élite who left after 1992 and returned voluntarily, while the 
second case, of Omar, represents the group of more modest descent who arrived in Europe at a later stage and had to return involuntarily.

\subsubsection{Nadir}

Nadir $^{3}$ is an Afghan voluntary return migrants in his early thirties whose family belonged to the Afghan urban élite. Nadir and his family escaped to Pakistan in 1992. From there, Nadir was, at the age of sixteen, the first of his family to travel to the Netherlands with the help of a smuggler, and after this his mother, brother and sisters also came to Europe. Nadir was recognized as a refugee, received support to build his life in the new country, and eventually received Dutch citizenship. With regard to this period, Nadir said that he always worked hard to keep up with his classmates because of language and adaptation problems and existing preconceptions about foreigners: 'I had to fight. It wasn't easy, but I did everything'.

The events of 11 September 2001 triggered his return. In the rush of attention on the war in Afghanistan, Nadir, who was a journalism student, could step forward as an expert on Afghanistan who spoke the local language and had received a Western education. After being an assistant journalist and translator for the Dutch media in Afghanistan, he was offered a well-paid job at an international aid organization. Ten years after his first return to Afghanistan, he still works there.

In Nadir's life, three spaces of embeddedness, which have different meanings for him, can be identified. The Dutch society as a space of embeddedness meant in the first place a safe haven. Nadir kept his Dutch apartment so that he could go there if the security situation in Afghanistan deteriorated, and to escape the stressful working environment of Afghanistan every now and then. In addition, the Netherlands was a place of socio-economic wealth, where facilities are better and comfortable housing and leisure activities make life easier. He said:

I have a born love for my country, but a rational respect for the Netherlands. It gave me everything that I could never get in Afghanistan.

- Nadir (voluntary returnee (m), interview, original in Dutch)

Afghanistan was a place of opportunities where he, as one of the few better-educated people in the country, could combine a well-paid career with a feeling that he could contribute to rebuilding Afghanistan. Nevertheless, he sometimes found it difficult to identify and interact with Afghan social life.

Life here is meaningful. We work on the law system of Afghanistan. (...) I speak the language and I know the culture and the job is interesting. The other side is that you don't have a social life, except for some relations. You cannot have a normal social life. (...) And the insecurity. That's really eating up your energy.

- Nadir

\footnotetext{
${ }^{3}$ To protect the privacy of the participants in this study, all names are pseudonyms. For the same reason, details such as towns or countries of residence are sometimes intentionally unspecified.
} 
Socially, Nadir related to the Dutch space of embeddedness, where a 'normal' social life for him included having a beer outside at a bar with a couple of friends, although that image now also seemed strange. He chose to live separately from his relatives as he said he became too Western to handle the lack of privacy of an Afghan family home. Nevertheless, he was still drawn to his Afghan social network, and explained that as a successful migrant with an international job after return, he was now seen as a role model, and he felt responsible for the wellbeing of his extended family. At the same time, the burden of the responsibility for his relatives (see Jazayery 2002) also distanced him from them and put restraints on his behaviour:

In Afghanistan you're always playing a role. If you talk with the community, you have to show that you're a good Muslim. (...) In the Netherlands, you can be yourself more.

- Nadir

Nadir was also strongly embedded in the large international community of Afghanistan through his employment. His Dutch passport worked like a reliability certificate for these employers, as it suggested a certain knowledge of and affinity with the Western working mentality. In turn, Nadir said he felt more comfortable with his network of international professionals and he identified more with the international than the local Afghan working conditions, as he found it hard to deal with the widespread corruption of the latter. Staying in the secure and well-equipped guesthouse of the international development organization where he worked made him logistically able to deal with the unstable security situation of Afghanistan. As a whole, Nadir said that if he were not working for an international organization, he would not be able to work in Afghanistan.

Nadir noticed that the security situation was deteriorating and he was becoming tired of the stressful situation. He planned to leave Afghanistan within the next few years.

I think it has been enough. I have tried to help Afghanistan for quite some time, and now I'd like to go back to do some sports, live a bit, think about myself a bit. - Nadir

Leaving Afghanistan would not necessarily imply going back to the Netherlands, as he felt unsure whether he would be able to find a job in the current economic and political climate that he felt had become less friendly towards foreigners. In deciding where his next place to work would be, he said: 'I have become a world citizen. I could live anywhere'.

Despite the difficult time he had experienced as a refugee and the ongoing dilemmas in his life, Nadir had benefitted from his migration experience. His multilocal embeddedness meant that he could fulfil different needs in different territorial and non-territorial spaces of embeddedness. His transnational mobility made him less bound by the structural restrictions of places. He could constantly re-evaluate his options for his private and professional life in the interplay between his desires and capacities for security, socio-economic opportunities and belonging. 


\subsubsection{Omar}

Omar is an Afghan involuntary return migrant in his early thirties. His family was not among the poorest in Afghanistan, but was not part of the élite either. Omar and his family fled Afghanistan because of the widespread generalized violence that erupted with the start of the civil war in 1992, when Omar was 14. The family lived as refugees in Pakistan and Iran. Omar commented on this period:

[A]ll the Afghanistan people, they just split up and they went to different places. I went to the UK and (...) Afghanistan just broke out like a tree. (...) one branch falls down, the other branch goes another way, one branch just burns and the other branch just gets dry and then at the end the actual tree has nothing. It's only a dry tree. This is what happened to me and at this time.

- Omar (involuntary returnee (m), interview, original in Dari, via translator)

With the metaphor of the tree, Omar illustrated that he felt that the conflict tore apart the social structure of Afghanistan and that of his family: some family members stayed in Iran, some went back to Afghanistan and others travelled to Europe and applied for asylum. Omar arrived in the UK in 2000. He was given temporary asylum status that allowed him to follow English classes and work temporarily at a bakery, before his status was withdrawn after the fall of the Taliban. He managed to linger on as an undocumented migrant, but was finally arrested and agreed to return in 2007, because he said: 'without the visa in a strange country you're just a prisoner'.

Omar's multidimensional embeddedness in both his former host country and in Afghanistan can be described as weak. As Omar never had a legal basis to live in the UK and only stayed there in an insecure temporary asylum situation, he did not have ongoing economic, institutional or cultural links with the country. Rather, he felt that the migration experience was a waste of time and money that prevented him from studying, doing relevant jobs or saving money. After his return to Afghanistan, he felt that he lacked the education, working experience and local connections to find employment. He moved from one low-skilled temporary job to another and was at the time of research working as an electrician for a telephone company. Without a Western passport, higher education or sufficient knowledge of English or other languages, the doors to the well-paid jobs in the international community also remained closed. The only and important link with Europe was through several of his brothers and sisters who still lived there and supported the family through remittances.

In Afghanistan, too, Omar's only basis for embeddedness was his family, who took him into the family home, where accommodation, food and income were shared. Omar felt lucky to be taken in by his family, although it also put him in a dependent situation.

[T]he thing is that in Afghanistan once you're in a circle, if the circle gets tighter and tighter you have to live with it. And you have to deal with it, (...) you cannot just get yourself out of the circle.

- Omar 
Omar indicated that he felt trapped in the 'circle' he was in. He highlighted the lack of agency over his own life and the feeling that he could only obey the wishes of his family. Although he had tried several times to leave Afghanistan again, he realized that his chances had decreased because of tightened asylum regulations and his lack of savings. This gave him the feeling of being stuck in Afghanistan. The feeling of having played and lost the 'migration game', resulting in an impoverished, immobile and dependent situation, had a strong psychological effect on him and was a source of anger and disappointment.

\subsection{Discussion}

Migration and return migration as a reinforcement of socio-economic
stratification

The life histories of Nadir and Omar are representative cases of voluntary and involuntary returnees from European countries to Afghanistan. They illustrate the strong patterns of how socio-economic background, migration experience, post-return embeddedness and post-return mobility are interlinked and reinforce socio-economic stratification, as presented in Table 6.4.

Table 6.4 Patterns of migration and return

\begin{tabular}{|c|c|c|c|c|c|}
\hline $\begin{array}{l}\text { Back- } \\
\text { ground }\end{array}$ & $\begin{array}{l}\text { Arrival in } \\
\text { Europe } \\
\rightarrow\end{array}$ & Legal status & Return & $\begin{array}{l}\text { Embedded- } \\
\text { ness }\end{array}$ & Mobility \\
\hline $\begin{array}{l}\text { Élite } \\
\text { (Nadir) }\end{array}$ & $\begin{array}{l}\text { End 1980s } \\
\text { early 1990s }\end{array}$ & $\begin{array}{l}\text { Refugee status } \\
\text { Citizenship }\end{array}$ & Voluntary & $\begin{array}{l}\text { Multi-local } \\
\text { and strong }\end{array}$ & $\begin{array}{l}\text { Transnationally } \\
\text { mobile }\end{array}$ \\
\hline $\begin{array}{l}\text { Modest } \\
\text { (Omar) }\end{array}$ & $\begin{array}{l}\text { Mid 1990s } \\
\text { early 2000s }\end{array}$ & $\begin{array}{l}\text { Temporary asylum } \\
\text { Rejected asylum } \\
\text { Undocumented }\end{array}$ & Voluntary & $\begin{array}{l}\text { Uni-local } \\
\text { and weak }\end{array}$ & $\begin{array}{l}\text { Involuntarily } \\
\text { immobile }\end{array}$ \\
\hline
\end{tabular}

Source: Afghan return migration study, 2012

Migrants who were members of the Afghan élite before migration often benefitted from their migration experience. Their voluntary return enabled multi-local embeddedness and continued transnational mobility. These returnees often kept their social, institutional and economic ties to their European country of residence. Their relative wealth and dual citizenship gave them the freedom constantly to re-evaluate their options to stay or move. They could combine the advantages of the different dimensions in multiple spaces of embeddedness by moving back and forth between the countries of their citizenship. In addition, a European passport did not only represent a feeling of belonging to the country, but was also an internationally recognized document that ensured the freedom of movement to any place in the world (Nagel and Staeheli 2004). Some of these returnees did not consider themselves as returned, but rather as living in two places.

On the other hand, migrants of more modest descent lost rather than won from their migration experience. Their involuntary return hampered their embeddedness, which was largely limited to Afghanistan, and resulted in a situation of dependency and involuntary immobility (Carling 2002). In the context of Afghanistan, this was 
very disempowering. As the opportunities for legal migration or asylum are being reduced both in the region and in Western countries, these returnees knew that their possibilities of moving were limited. Renewed migration would include even more dangerous and expensive travel routes, with a higher risk of failure. The prospect of having nowhere to go if the security situation in Afghanistan deteriorates caused an uneasy feeling of being stuck in Afghanistan.

Although the cases of Omar and Nadir represent a very strong general pattern in the data, this does not mean that all migration experiences develop along the same lines. There were respondents in this study with a high social background who returned involuntarily, and returnees of more modest background who returned voluntarily, which immediately mitigated the stratifying effect of migration and return. Moreover, migrants' individual experiences strongly vary within these general patterns, because of their personal desires and capacities, which will be discussed in chapter 7. The conclusions for this chapter will, however, focus on the remarkably strong general patterns that were identified.

\subsection{Conclusion}

The 'transnational turn' has raised renewed expectations in the debate on migration and development, and have led to the assumption that return migrants from industrialized countries have a number of characteristics that enable them to contribute to development upon return. However, the increased significance and benefits of mobility also make inequalities in the right or capacity to migrate an important dimension of social stratification. Research shows that mobility highlights not only differences between migrants and non-migrants, but also differences among return migrants. This chapter explored this new avenue of the hierarchization and social stratification of mobility (Castles 2007). Conceptually, I introduced multidimensional and multi-local embeddedness as an analytical approach to the multi-sited experience of migration, merging transnationalism and integration into one analytical framework.

This chapter showed how socio-economic differences that existed prior to migration are reinforced by the migration experience, and showed that this results in strongly differentiated patterns of post-return embeddedness and transnational mobility. Returnees who were members of the Afghan élite before migration often benefitted from their migration experience. Their early arrival and high profile led to refugee status, which enabled full participation in the host country and voluntary return, resulting in strong and multi-local embeddedness and continued transnational mobility. By contrast, Afghan migrants who were of more modest descent lost rather than won from their migration experiences. Their late arrival meant that they faced the disadvantages of increasingly restrictive asylum policies, leading to insecure legal status. This stood in the way of participating in the host country and resulted in involuntary return, which led to a weak multidimensional embeddedness that was largely limited to the Afghan space. The uneasy feeling of being 'stuck' in Afghanistan because of their involuntary immobility, and their relative failure compared to successful returnees (Carling 2004), made them feel impoverished, disempowered and frustrated. 
The results of this chapter show, in addition to the assumptions that underlie migration and development policies, that not all migrants are members of the élite, that not all returnees benefit from their migration experiences and that not all returnees are strongly multi-locally embedded. Instead, the opportunities that migrants have to accumulate skills, knowledge and savings in their host country, which they may invest after return, are unequally distributed among different types of migrants. Previously existing socio-economic differences are reinforced by the migration experience, which results in strongly differentiated patterns of multi-local embeddedness and transnational mobility. This finding restricts expectations of return migration and development. 
Women seem wicked

When you're unwanted

The Doors - People are Strange 


\section{7 \\ Love (n)or marriage}

Negotiating belonging to one or multiple spaces of embeddedness

\subsection{Introduction 1}

In this globalized world, newer, cheaper, and more efficient modes of communication and transportation enable migrants to maintain multi-local ties that transcend national borders and boundaries simultaneously and on a day-to-day basis (Vertovec 2001, Long and Oxfeld 2004a, De Haas 2010). Migrants may be multi-locally embedded, where embeddedness is defined as an ongoing process of an individual's identification with and participation in spaces of belonging (see chapter 6 and Van Houte, Siegel, and Davids 2014).

This transnationalization of migrants' lives raises questions about the impact of migration on identity, the social process in which 'people conceive of themselves and are characterized by others' (Vertovec 2001, 573, Gardner and Grillo 2002, Buitelaar 2006). Migrants may feel at home in several places, forming complex, in-between and hybrid identities (Davis, Kuipers, and Lutz 1995, Ahmed 1999, Vertovec 2001, Ghorashi 2003, Pedersen 2003, Long and Oxfeld 2004a, Easthope 2009, King and Christou 2010). This implies that integration into receiving societies and commitment to origin societies are not necessarily substitutes, but can be complements (De Haas 2010, Dekker and Siegel 2013, Erdal and Oeppen 2013). It furthermore highlights that migrants become disembedded from fixed notions of identity, and assumes their rearticulation in uprooted, nomadic and cosmopolitan forms of belonging (Ahmed 1999, Mai and King 2009). Migrants are expected to choose consciously from different elements of their multi-local identities (Ghorashi 2003, König 2009).

The transnational turn has therefore raised renewed expectations within the debate on migration and development. First, it is assumed that migrants' multi-local ties make them potential mediators between cultures. Their identification with 'modern' ideas, norms and values, combined with their feelings of belonging to the country of origin, would give them the opportunity to transfer knowledge and skills and change existing structures (Potter 2005, Jones 2011). Second, it is expected that their 'in-between' position makes them relatively independent of the constraints of structures, giving them the agency to negotiate change (Portes 1999, Sørensen, Van Hear, and Engberg-Pedersen 2002).

Despite this 'hyperglobalist' ideal (Carling 2002), people's identities are the result of a negotiation process, as people influence and are influenced by the social worlds in which they are located (Findlay and Li 1997, Emirbayer and Mische 1998,

\footnotetext{
${ }^{1}$ This chapter is based on: Van Houte, Marieke, and Tine Davids. Forthcoming/b. "Love (n)or Marriage: How do Afghan return migrants from Europe negotiate belonging to one or multiple spaces of embeddedness?" (currently under review).
} 
Kloosterman, Van Der Leun, and Rath 1999, Sherrell and Hyndman 2006). Migrants who display hybrid identities that deviate from the dominant norms and traditions (Portes 1999, Cochrane 2007) may experience a 'double marginality' that makes them outsiders to both societies (Ghorashi 2003, Tsuda 2004, 23, Potter 2005, König 2009, King and Christou 2010). Return migration further complicates this process, as formerly familiar people and places have also changed (Pedersen 2003, Long and Oxfeld 2004a, De Bree, Davids, and De Haas 2010, Chan and Tran 2011). Moreover, the resources of communication and transportation are not equally divided, which makes the postmodern, transnationally fragmented and nomadic lifestyle a privilege for the relatively wealthy (Bakewell 2008, Mai and King 2009, see chapter 6 and Van Houte, Siegel, and Davids 2014).

This chapter analyses how Afghan migrants returning from European countries negotiate belonging to one or multiple spaces of embeddedness. It explores the question of whether these returnees can 'play' or 'manage' multi-local, hybrid and 'inbetween' identifications to their advantage, or whether they become 'in-between' victims of contrasting expectations and identifications (see Ahmed 1999, Ghorashi 2003, Pedersen 2003, Easthope 2009). Insights into these processes can inform the debate on migrants' contributions to development through culture mediation and the negotiation of change. On a conceptual level, a focus on the 'human dynamics' or relational aspects of transnationalism (Carling 2008) provides an important addition to the predominantly economically orientated literature on transnationalism (Gardner and Grillo 2002, Charsley and Shaw 2006).

The study took an in-depth approach, focusing on the life histories of 35 Afghan returnees to Kabul. ${ }^{2}$ The motivation for return proved to be of great importance for post-return embeddedness (see chapter 3 and Van Houte and Davids 2008, Ruben, Van Houte, and Davids 2009), while legal status in the nation state is important in shaping transnational practices (Gardner and Grillo 2002, see chapter 5 and Van Houte, Siegel, and Davids Forthcoming). Therefore, I explicitly compared voluntary returnees who had the legal possibility of staying indefinitely in the country of destination with involuntary returnees who returned without such a status (see chapter 5 and Van Houte, Siegel, and Davids Forthcoming).

From the collected narratives, the subject of marriage, sexuality and gender norms, although not a predefined subject of interest of this study, emerged as an important domain in which negotiation of belonging took place. Although these private and emotional dimensions of transnationalism often escape the researcher's attention (Gardner and Grillo 2002, Mai and King 2009), the research methodology allowed the topic to emerge from the data. This is no coincidence, as marriage is one of the major transition phases in people's lives. Marriage is an important multi-vocal performance and site to express and negotiate belonging, status, conflict and change (Gardner and Grillo 2002, Christou 2006, Hitlin and Elder 2007). The study of the diversity of the patterns, meanings and consequences of marriage in the context of migration takes us further in understanding transnationalism from the socially and culturally grounded perspectives of the actors involved (Charsley and Shaw 2006). Changing practices and ideas of marriage and family dynamics reflect migrants' adaptation strategies and the complexity of simultaneously negotiating belonging to

\footnotetext{
${ }^{2}$ Chapter 2 describes the methodology of this study.
} 
individual and collective identities (Mai and King 2009, Abbasi-Shavazi et al. 2012). Last, the 'gender-and-sexuality frame' is central in debates that highlight the 'essential differences' and the 'clash of civilizations' between (Muslim) migrants and the liberal democratic world (Bilge 2010).

The next section provides a literature review on identity, marriage, migration and change. After that, the narratives of the returnees with regard to marriage, sexuality and gender are analysed to identify different responses in the interplay between desires and capacities of belonging. I conclude that although all returnees can display agency over their personal choices, the expectation that return migrants can mediate between cultures and negotiate change in existing structures is overstated.

\subsection{Marriage, sexuality, gender, migration and change}

Bakewell argues that if we are to make progress in understanding the relationship between migration and social change, it is essential to analyse the interplay of structure and agency (Bakewell 2010). Agency can be seen as an actor's attempt to match his or her desires and capacities, while being shaped by, and shaping, the structural context, defined as the forces that are external to and have an impact on people (see chapter 5 and Van Houte, Siegel, and Davids Forthcoming). It is argued that the more that actors are embedded in structures, the more they have the agency to apply flexible, inventive and critical responses to unfamiliar, contradictory or otherwise problematic situations. Such responses can entail changing structures to some degree (Sewell 1992, Emirbayer and Mische 1998), as well as choosing to 'live' within a structure instead of changing it (Bilge 2010).

The specific understanding of marriage, sexuality and gender, the power dynamics underpinning them, the behaviours associated with them, and the role they should play in key life choices, are embedded in cultural, social, economic and institutional structures (Mai and King 2009). Rituals such as marriage can change as they are arenas of contest or of the negotiation of power, status and boundaries of 'community', history and identity (Gardner and Grillo 2002). In the context of migration, practices and expressions of marriage, sexuality and gender can illuminate contemporary processes of globalization (Gardner and Grillo 2002, Charsley and Shaw 2006, Christou 2006).

Gender relations and the dynamics of marriage and sexuality both shape, and are shaped by, migration and transnational practices, which underlines the dynamic nature of transnationalism (Gardner and Grillo 2002, Charsley and Shaw 2006, Christou 2006). First, marriage, sexuality and gender may be shaped through the confrontation of migrants with multiple and sometimes contradictory value systems in the countries of destination and origin. When migrants return, they can highlight their ambiguous status of being both insiders, by performing traditional rituals, and outsiders, by emphasizing differences in those practices, which makes them agents who can reformulate discourses (Salih 2002). However, the negotiation of difference is a delicate task that requires social and cultural skills, especially when the negotiation is between conflicting norms and practices (Sadat 2008). In this context, it is argued that the discourses of Western feminism have 'hindered a more subtle appreciation of women's issues under Islam' (Singh 2010, 26). 
Second, the transnational context may shape the structures of marriage and the norms that guide family life (Gardner and Grillo 2002, Mazzucato and Schans 2011). Families become transnational when their members become separated as a result of migration across borders, either because of restrictions such as migration policies or because of family strategies (Mazzucato and Schans 2011, Piotrowski and Tong 2013). Transnational families can take advantage of this by spatially dividing their different needs and obligations on multiple dimensions of embeddedness. At the same time, being continuously split by the need to be with people in different places can also represent a disadvantage for the transnational family (Mazzucato and Schans 2011, Charsley and Shaw 2006).

The emergence of transnational households can affect power relations within the marriage: for example, migrants may depend on their spouses for their residence status and may therefore be unable to leave a dependent or violent relationship. On the other hand, migrant women may find themselves outside the control of their inlaws or other social environments, while women 'left behind' may enjoy increased autonomy in the country of origin (Charsley and Shaw 2006).

Transnational households may also create opportunities and motivations for new marital constructions, such as transnational parallel partnering (Gerholm 2003, Charsley and Liversage 2013). Transnational parallel partnering may function as a means for legal settlement, or of meeting emotional needs, or of fulfilling dual marital aspirations; both having the 'love match' of their choosing, and marrying the spouse selected for them. In all cases, 'the physical distance created by migration may facilitate the concealment of a pre-existing or new marriage from the other spouse, or from the relevant authorities' (Charsley and Liversage 2013, 64). Changed gender patterns in turn affect migration patterns, resulting, for example, in the reluctance of female migrants in industrialized countries to return to more unequal gender positions in their countries of origin (Guarnizo 1997, Ammassari 2004).

\subsection{Discourses of marriage, sexuality and gender}

Many returnees in this study highlighted the intensity of the fundamentally different and often opposing value systems with regard to marriage, sexuality and gender of their country of origin and their former host country. With their narratives on these topics, they highlighted their own position in these discourses (Bilge 2010). In doing so, they left internal differences based on region, religion and ethnicity largely unmentioned. The fundamental differences between 'Western' and 'Afghan' ideologies, which underlie discourses of marriage, sexuality and gender (Sadat 2008, Singh 2010), are therefore a strategic domain for exploring return migrants' identifications and their agency to negotiate change (Mai and King 2009). Although there is no such thing as 'Afghanistan' or 'Europe' as a mono-cultural entity, I will therefore discuss some of the most marked features of 'Afghan' and 'European' discourses of marriage as they come forward in the literature and were represented by the respondents.

Afghan marriage is central to social life and traditionally forms a relationship between groups rather than individuals (Charsley and Shaw 2006, Smith 2009). Marriage has not only a procreational role, but is also a mechanism to fulfil economic 
and social needs, serving as a survival and coping strategy in times of war and insecurity (Smith 2009). By arranging marriages with relatives and, more specifically, with patrilineal first cousins, families strengthen their social support networks and their power for collective action, ensuring social cohesion among families (Wahab, Ahmad, and Akram Shah 2006, Abbasi-Shavazi et al. 2012, Ismailbekova 2013).

In addition to this socio-economic function, marriage is used to control men's and women's sexuality in the wider cultural context where honour and shame are important (Smith 2009). Families tend to marry their daughters early, so that their married status and the protection of the husband's family keep them from being raped and from other extra-marital sexual activity. Similarly, sons are married in the hope that the burden of the responsibility of a family prevents them from becoming involved in fighting or other risky behaviour (Ismailbekova 2013). If either of these social functions cannot be fulfilled within a marriage, for reasons of death or infertility, men are allowed to marry multiple wives. Divorce is however not a socially accepted solution (Smith 2009).

Different types of decision-making arrangements can be identified. First, the option in which control is maintained over all the social and economic functions of marriage is the arranged marriage, where the parents and elders of both families decide on the marriage, and the bride and groom do not meet before the wedding. The second option is the assisted marriage, where relatives and friends help to facilitate the marriage but do not have primary decision-making. More rare is, third, the nonarranged marriage, which is sometimes also referred to as a 'love marriage', where spouses have met each other in a setting outside of the household and make an independent choice to marry (Abbasi-Shavazi et al. 2012). While arranged marriages are often thought of as being based on the corporate interests of the families, 'love marriages' are supposed to be based on the romantic attachment of the couple (Charsley and Shaw 2006). A summary of the characteristics of Afghan discourses of marriage is displayed in Table 7.1.

Table 7.1 Characteristics of 'Afghan' and 'European' discourses of marriage

\begin{tabular}{|lll|}
\hline & 'Afghan' & 'European' \\
\hline Decision & Family / arranged & Individual / choice \\
\hline Function & Collective & Private \\
Procreational & Only within marriage & Preferred within marriage \\
Security & Strengthened through marriage & Less important \\
Sexuality & Controlled through marriage & Separate from marriage \\
\hline Practices & & \\
Polygamy & Accepted & Taboo \\
Marrying relatives & Accepted & Taboo \\
Divorce & Taboo & Accepted \\
Homosexuality & Taboo & Accepted \\
\hline
\end{tabular}

Sources: Salih 2002; Wahab, Ahmad, and Akram Shah 2006; Mai and King 2009; Smith 2009; Abbasi-Shavazi 2012; Ismailbekova 2013

Afghan migrants in Europe found fundamental differences in the marriage, sexuality and gender norms from those of their country of origin. Following historical sociological changes such as secularization and the growth of material wealth, the 
institution of marriage in Europe has shifted from being a financial or familial obligation (Bloch 2011). Rather, the Western meaning of marriage is centred on individual choice and a multiplicity of options, which resonates deeply with the ideologies and practices of modernization (Salih 2002, Mai and King 2009). Central to this individualistic concept of modernity is the concept of 'love' amongst 'equal' individuals, celebrating the expression of individual autonomy, gender equality and emotional fulfilment (Mai and King 2009). Although the family is still a central institution in society and is important in procreation, sexuality and marriage have become increasingly separated practices. This focus on individualism results in a wider variety of possibilities regarding love and marriage, including the free choice of a partner, same-sex relationships, premarital sex and cohabitation. Within this context of individuality, divorce and separation are also more common. However, marrying relatives or having multiple spouses is taboo and, or illegal.

Table 7.2 shows an overview of the respondents of the study, based on return motivation, gender and marital status. Most returnees in this case study were male, reflecting a demographic reality that migratory movements are gender selective. Involuntary returnees were often men who had travelled alone, and returned alone, before they were able to bring their family over (see also Schuster and Majidi 2013). Female respondents were also a minority among voluntary returnees, which is consistent with observations that female migrants are reluctant to return to a country with greater gender inequality than their host country (Guarnizo 1997, Ammassari 2004). This reality, however, puts a strong male bias on these narratives on highly gendered issues of marriage, sexuality and gender.

Table 7.2 Return motivation, gender and marital status of respondents

\begin{tabular}{|c|c|c|c|c|c|}
\hline & \multicolumn{2}{|c|}{ Voluntary } & \multicolumn{2}{|c|}{ Involuntary } & \multirow[t]{2}{*}{ Total } \\
\hline & $f$ & $m$ & $f$ & $m$ & \\
\hline \multicolumn{6}{|l|}{ Marital status } \\
\hline Unmarried & 3 & 6 & - & - & 9 \\
\hline Married or relationship, spouse in Europe & 1 & 6 & - & - & 7 \\
\hline Married pre-migration, living with spouse & - & - & - & 4 & 4 \\
\hline Married post-return, living with spouse & - & 4 & - & 11 & 15 \\
\hline Total & 4 & 16 & 0 & 15 & 35 \\
\hline
\end{tabular}

Source: Afghan return migration study, 2012

\subsection{Negotiating love or marriage}

The migration experience and the voluntary or involuntary return strongly affected returnees' capacities to become embedded in multi-local spaces. Voluntary returnees had been legally able to participate fully in the host society. Some had lived in the host country with their Afghan spouse, while other, younger, respondents were single at the point of return. After return, they had the capacity to maintain ties to multiple spaces of embeddedness and they continued to be transnationally mobile.

In contrast, involuntary returnees had only partly participated in, and were eventually rejected by, the host country. Although many involuntary returnees had love affairs in Europe, they did not have the capacity to maintain ties with the host 
country. In addition, they were often weakly embedded in the country of return, which made them dependent on their relatives' support. Their situation was characterized by involuntary immobility (see chapter 6 and Van Houte, Siegel, and Davids 2014). A lively metaphor for these migrants' lives in the European host country was given by Wasim, ${ }^{3}$ describing his relationship with European women:

There are beautiful girls but you cannot talk to them, (...) once you're with them, all the time you're with them, you're living with each other and once they don't like you, excuse my language, they will say fuck off.

- Wasim (involuntary returnee (m), interview, original in Dari, with translator)

While the migration experiences therefore strongly determined returnees' capacities, returnees also displayed a variety of desires. Three different types of desires could be identified with regard to marriage, sexuality and gender norms: the desire to belong only to the European value system, the desire to belong only to the Afghan value system, and the desire to reconcile belonging to both systems.

The intersection of capacities and desires defined the room to manoeuvre within which returnees could negotiate belonging. This creates a framework based on these 'spaces' of negotiation, which is shown in Table 7.3 and will be discussed below. Although this is a relevant framework for analytical purposes, it should be noted that desires and capacities are neither static nor absolute. Returnees therefore shift between spaces of negotiation over time or for any domain or dimension of embeddedness.

Table 7.3 Spaces of negotiation based on capacities and desires regarding marriage, sexuality and gender norms

\begin{tabular}{|rrll|}
\hline \multicolumn{3}{|l|}{ Capacities } \\
\cline { 2 - 4 } Desires & Multi-local (European \& Afghan) & Uni-local (Afghan) \\
\cline { 2 - 4 } & European & 1. Transnational European & 2. (Failed) European \\
\cline { 2 - 4 } & Reconcile both & 3. Transnational 'in-between' & 4. Uni-local 'in-between' \\
\cline { 2 - 4 } & Afghan & 5. Transnational Afghan & 6. Uni-local Afghan \\
\hline
\end{tabular}

Source: Afghan return migration study, 2012

7.4.1 Love and gender equality: negotiating belonging to 'European' value systems

\section{Transnational European}

The 'transnational European' space of negotiation emerged when voluntary returnees had the desire to negotiate belonging to the marriage, sexuality and gender norms of the European country of residence, without reconciling this with the Afghan value system. They could only do this by practising this part of their lives in the European country of residence, thus splitting different functions of 'home' over different spaces

\footnotetext{
${ }^{3}$ To protect the privacy of the participants in this study, all names are pseudonyms, or are unmentioned. For the same reason, details such as towns or countries of residence are sometimes intentionally unspecified.
} 
of embeddedness, which in this case implied a high degree of transnational mobility (see also Oeppen 2009). For male returnees who were married, a common strategy for achieving this was to work in Afghanistan while their wives and children stayed in the European country of residence. Creating transnational households allowed the freedom and security their wives had in Europe to be maintained, while other needs such as career and income were fulfilled in Afghanistan. Nevertheless, the case of Fahima, a female returnee who left her husband and children in Europe, shows that this strategy is not purely about gender, but also about security (see also chapter 8 and Van Houte Forthcoming).

For single returnees, the 'transnational European' space of negotiation meant that they could relate to 'Western' discourses of sexuality, which included having girlfriends without getting married, while at the same time as they were working, maintaining social relations and being good Muslims in Afghanistan. While these are mutually exclusive concepts in the Afghan discourse, their transnational mobility allowed them to lead a 'transnational double life' in which they could conceal these two worlds from each other. A young male respondent explained:

\author{
My family thinks I'm still a virgin. If they'd ever find out that I had girlfriends, I \\ would be completely rejected. \\ - Voluntary returnee (m), interview, original in Dutch
}

This respondent indicated the enormous social risk involved in this 'transnational double life', which required careful management, and dealing with questions as to why he was still not married. Nevertheless, following a 'transnational European' strategy meant that returnees did not need to reconcile the different value systems, nor did they negotiate change.

\title{
(Failed) European
}

As people tend to match their desires with their capacities, the desire to negotiate belonging only to the marriage, sexuality and gender norms of the European 'host' country while not having the capacity to do so is not likely to be displayed except in very pressing cases. A homo- or bisexual orientation, which is generally accepted in Europe but problematic in Afghanistan, could be an example, although this did not appear in this study. While they were in the host country, several involuntary returnees had tried to claim legal status through their engagement with a girl. In addition, Wahid and his girlfriend tried to claim asylum on the basis of their love relationship that they said would be problematic upon return. However, after this failed and they had to return, they adopted other strategies, which will be described below.

\subsubsection{Love (n)or marriage: Negotiating 'in-betweenness'}

\section{Transnational 'in-betweenness'}

Rather than 'home' being split over different spaces of belonging, transnational 'inbetweenness' emerged when voluntary returnees identified with and tried to reconcile belonging to multiple places with regard to marriage, sexuality and gender 
norms. A first strategy within this space of negotiation was displayed by Fahima, who tried to find an 'in-between' solution of marriage for her daughter, who lived in Europe, which was acceptable for both spaces of embeddedness. Being economically and socially tied to two places, she carefully chose her expressions and practices regarding her daughter's marriage in order to produce an 'in-between' narrative that could be accepted by both, when she said the following:

My daughter has received a [marriage] proposal [from an Afghan relative]. But I said, she's going to school in [European country] and there she learned that cousins marrying are like brother and sister to marry, so she doesn't want that. (...) It's her choice. Not that she can have a boyfriend. Not at all. She can just say yes or no.

- Fahima (voluntary returnee (f), informal meeting, original in English)

Fahima used the school as a respected authority to communicate this change, which freed her from taking full responsibility for it. Not marrying a cousin and a hint of free will is a gesture indicating belonging to the 'Western' discourse, while remaining within frameworks of marriage that are acceptable for Afghanistan.

While Fahima could make minor changes that were accepted within both discourses, two young male returnees found it hard to reconcile the more fundamental differences of the multiple discourses with which they identified. Both were unmarried men in their thirties who had returned to Afghanistan for its employment prospects and to search for their Afghan 'roots'. While they questioned the volatile relationships they had previously had in Europe, they found it unacceptable to marry a girl they had never met and to spend tens of thousands of dollars on the wedding. During one of the group meetings, a passionate discussion started:

Returnee 1: Also locals, local Afghans they have problems with it, how to choose their partners. I mean they do, the way they do it in Afghanistan, but actually they're not happy with it. (...).

Researcher: So how are guys like you going to do that? (...)

Returnee 2: Marieke, what do you mean...We are Afghans, local Afghans! (...)

Researcher: No I mean guys like you who are criticizing this, this system. (...)

Returnee 1: Eh oh. We're not criticizing.

Returnee 2: It isn't criticizing. (...) Because it's only in Afghanistan, I can't change it. I can go and marry other girls without problems. Just in Afghanistan, just show how it is and how it changed over the years. It was not like this all the time you know.

Returnee 1: No we cannot change it, because we are just two out of 30 million people, we cannot change the way it is. And I can understand it, this is a cultural thing. Nobody can go to a house and say I like your daughter, I would like to know her more, so am I allowed to speak with her.

Researcher: So if you're gonna be here, if you're gonna live here, then you'll just have to deal with it? The way he (the translator) did it?

Returnee 1: I will never do that, that's why I'm still single. (...)The only thing is when you're really desperate, then you go the Afghan way. 
Returnee 2: I've got a solution, as I told you, I don't wanna change things here, but if I like really a girl I talk with her parents, very honestly, I like your daughter but I don't wanna invite like 800 people.

Returnee 1: You cannot go to a house and say I like your daughter. You cannot do that.

Translator: You get in trouble, yeah.

Returnee 2: You will be kicked out immediately.

- Voluntary returnees (m), group meeting, original in English

These returnees, but did not succeed in reconciling their belonging to fundamentally different value systems, and could not find an 'in-between' solution. Consistent with Salih's (2002) observation, they presented themselves both as insiders by saying 'we are local Afghans' and as relative outsiders, when they talked about them, the local Afghans, who were stuck in a system. They highlighted that, unlike these local Afghans, he could 'go and marry other girls without problems'. However, they could not negotiate a practice of marriage that would make them both accepted as Afghans while also meeting a sense of choice and individualism that would reconcile them with their 'European' sense of belonging.

A second strategy for negotiating belonging to different value systems was not to try to reconcile these practices, but to live both value systems, in a different variety of the 'transnational double life', in order to meet 'dual marital aspirations' (Charsley and Liversage 2013). This was displayed by one returnee: his wife, with whom he had an arranged marriage, lived in their European country of residence, while he also had younger girlfriends in different countries. His high international salary and transnational mobility provided the opportunity both to meet traditional expectations of marriage and support his family financially, and to have extra-marital relationships in different countries without drawing these to his wife's attention. Although only this one respondent spoke openly about his experiences regarding this sensitive topic, several informants mentioned the widespread practice of transnational parallel relationships. Transnational polygamous extra-marital relationships can be seen as a transnational 'in-between' modification, lying between Afghan polygamous marriage and the 'Western' idea of non-marital sex and multiple relationships. Their transnational mobility enabled a best-of-both-worlds scenario for individual migrants that avoided tensions among co-wives in a regular polygamous household (Charsley and Liversage 2013). However, like the other returnees in this space of negotiation, they were not able to negotiate 'in-between' solutions openly.

\section{Uni-local 'in-betweenness'}

Uni-local 'in-betweenness' emerged when involuntary returnees identified with and tried to reconcile belonging to multiple places with regard to marriage, sexuality and gender norms, but failed because of their weak ties with the former host county. This caused pressure to negotiate belonging to the country of return, and particularly to belong to their families who were often their main source of support. Omar, an involuntary returnee from the United Kingdom, tried to introduce some 'European' practices into his Afghan life by starting a secret love affair with the girl next door shortly after his return. He gave an account of how their affair was discovered and was followed by a long sequence of problems, including death threats from the girl's 
family, to indicate that this was unacceptable in his social environment. His own family also disapproved.

My mum is also saying you did a bad job, this is not our culture, why did you do that? Do you believe this is the UK? Now this is not the UK!

- Omar (involuntary returnee (m), interview, original in Dari, via translator)

After the storm around this affair settled, Omar was persuaded into an arranged marriage with another girl. When the researcher spoke to him after the wedding, he was furious about the high bride price and about his feeling that his in-laws were taking advantage of him. However, he made it clear that he saw no other way than to obey his family.

My mum said to me (...) that only (the) girl is not important, her family is also important, you have to know the family, how they are and these sort of things. And (...) I did accept what my mum told me, but just made me unfortunate.

- Omar

Omar and other involuntary returnees who were in this 'in-between' situation stressed their dependency on their families, who insisted on the concept of marriage as a family strategy. In addition, these families seemed to use arranged marriages as a strategy for making their sons settle down, stopping them from re-emigrating and keeping them out of trouble (Charsley and Shaw 2006, Ismailbekova 2013). Kamal, who had a girlfriend while in Europe, said his family would have allowed him to have a non-Afghan girlfriend if that could have been instrumental in obtaining his residence status. This corresponds with the idea that marriage, like migration, is part of a family's socio-economic survival strategy (Smith 2009). However, now that he was back, his family wanted him to end the relationship and marry an Afghan girl instead. Within this limited room to manoeuvre, while their anger displayed their resistance and the fact that they did not give in easily, the returnees' strategy for displaying agency within a structure that they could not change was to obey the will of their family and negotiate belonging to the Afghan discourse.

\subsubsection{Arranged marriage and masculinity: negotiating belonging to 'Afghan' value systems}

\section{Transnational Afghanness}

Transnational Afghanness was the space of negotiation for voluntary returnees who were frustrated by their life in Europe and displayed the desire to negotiate belonging exclusively to the Afghan space of embeddedness. Many of these returnees also linked their frustration to narratives of marriage, sexuality and gender. For example, Tareq explained how the mother of his Dutch wife had ruined their relationship, because she distrusted foreigners, Muslims and Afghans after the events of 11 September 2001. After the divorce, they had a conflict over the custody of their children, in which he felt disadvantaged. 
If they respect the man less than the woman. (...) A man has just as many rights to [have] the children as the woman. And all rules are [twisted] and they give them to the woman (laughs). And the man is outside without anything. Rules rules rules laws laws laws. It was all too much for me. I got all confused there.

- Tareq (voluntary returnee (m), interview, original in Dutch)

Tareq related his failed marriage to a narrative of discrimination against Afghans, Muslims and men. At the height of his frustration, Tareq followed his impulse to return to Afghanistan and took a radical turn towards Afghan traditional marriage. He stated firmly that he would never return to the Netherlands again.

Another young male returnee was, rather than by gender norms, disappointed by the Western concept of 'love'. After the sudden ending of his relationship in Europe, he entered a period of depression. After a visit to his parents in Afghanistan, they asked him to have an arranged marriage.

So I thought maybe this is the solution, to marry her. And it worked. I never want to be in love again, it distracts you so much (...). But I really came to love my wife, she is the best. But I don't want to be in love again.

- Voluntary returnee (m), interview, original in English

This respondent related to the Afghan argument that being 'in love' is an unstable and emotional basis for a relationship, while couples in an arranged marriage will come to love each other from a more stable and rational background.

While these two men reacted to the frustration they experienced in the European country of residence by becoming Afghan 'all the way', their radical decisions still took place within the capacities of their multi-local embeddedness. Immediately after his wedding, the latter respondent started the process of applying for Dutch citizenship for his wife. At the time of research, his wife was living in the Netherlands to complete her citizenship procedure while he was working in Afghanistan. They planned to live together in Afghanistan as soon as she obtained her Dutch passport, while their Dutch passports would make them both transnationally mobile, allowing them to leave Afghanistan easily if there were problems (see also chapter 6 and Van Houte, Siegel, and Davids 2014). Similarly, despite his resentment towards the Netherlands, Tareq said that he and his wife were contemplating leaving for a third country if the security situation deteriorated. While they were unwilling to negotiate changes in the value system of the traditional marriage, their transnational mobility allowed them to make modifications in its geographical space for their own benefit.

\section{Uni-local Afghanness}

Uni-local Afghanness emerged when involuntary returnees displayed the desire to belong to the Afghan discourse with regard to marriage, sexuality and gender norms. First, when the researcher dropped into conversation the observation that most unmarried involuntary returnees had a traditional arranged marriage within a year of their return, Hamid replied:

You really need it the whole time. Without women you cannot live. Especially if you're used to her. Having a wife is very important. The only reason and the main 
reason that we got married was because we had to, we could not live without a woman.

- Hamid (involuntary returnee (m), group meeting, original in Dari, via translator)

Hamid highlighted that he had sought continuation of his (sexual) experience after return and that an arranged marriage was his personal strategy for fulfilling these individual needs within the context of Afghanistan. Many of these returnees also claimed agency over their return through their expressions and practices of marriage, sexuality and gender norms. Several involuntary returnees argued that they would not want to live in Europe with their families, because of different social and gender values. Mahmood even mentioned this argument as the direct reason for his return.

He (the asylum agency interviewer) said, what if you come to a party with your wife and a stranger comes and puts their hands to your wife's hand and ask her for a dance. What will you do? I said I will punch him in the face as much as I can until I get very tired. And that was the main problem about my case. That was the cause of not processing [my asylum claim].

I'll either kill that guy or beat him as much as I can. And then what I said was delivered to the police and it caused that problem for me. I knew that they are the people who are interviewing us and they take to the police everything we say. I just did it deliberately.

- Mahmood (involuntary returnee (m), group meeting, original in Dari, via translator)

Mahmood's narrative of the clash of gender norms worked as a vehicle for claiming agency over his return, which he displayed as an act of resistance, while he actively and publicly denounced 'European' gender norms in favour of 'Afghan' ones. Other returnees stressed their masculinity by highlighting the lack of authority and control that a man has over his wife and children in Europe.

I want to have a control on my kids and on my wife. There is not that way. There you cannot just tell your kids do this or don't do that. Other thing is that no father will want their kids or wife to go to a bad way. There you cannot do it [discipline your wife and children] because once or twice you do it [and] the third time, the last chance the police will come and take your kids with them.

- Rafiq (involuntary returnee (m) group meeting, original in Dari, via translator)

Interestingly, in individual meetings, several respondents said that these statements rejecting Western society, women and values were not genuine. For example, Kamal said that the same people making these statements would not hesitate to go back to Europe if they had the chance. He added:

The people who are talking about (...) being in Holland is really hard because you cannot control your daughter and you cannot control your son or your family, your wife, I mean just nonsense, those things are really nonsense to me, they are just saying it. Because there are a lot of Afghan families in different countries. And they're 
not prostitutes, they are not whores, I mean they do their prays and they're fasting like other Afghans in Afghanistan and they do everything and according to Islam, but they have a good life there.

- Kamal (involuntary returnee (m), interview, original in Dari, via translator)

Indeed, many returnees who made such cultural statements asked the researcher at other times for assistance in returning to Europe (see also chapter 5 and Van Houte, Siegel, and Davids Forthcoming). Their statements therefore did not so much reflect an aversion towards the European lifestyle, but were claims made to highlight their belonging to the Afghan discourse. Instead of displaying regret for their failure to maintain ties with the host country, they reclaimed their dignity and masculinity by denouncing the European discourse.

\subsection{Conclusion}

In an increasingly globalized and transnational world where migrants can maintain multi-local ties to multiple spaces of embeddedness, questions are raised about the impact of migration on identity. This chapter addressed the need for a focus on the 'human dynamics' of return. It explored how Afghan migrants returning from European countries negotiate belonging to one or multiple spaces of embeddedness through their expressions and practices of marriage, sexuality and gender norms. Insights into these processes can inform the debate on migrants' contributions to development and peace-building by mediating between cultures and negotiating change. As marriage is a major transition phase in people's lives, it is an important site to express and negotiate belonging, status, conflict and change. Practices and expressions regarding marriage, sexuality and gender norms can reflect migrants' adaptation strategies and the complexity of simultaneously navigating cultures and negotiating belonging (Mai and King 2009, Abbasi-Shavazi et al. 2012).

The findings confirm that, instead of there being dichotomies between victims and agents, all returnees can be seen as agentic players who are attempting to match their desires and their capacities. At the intersection of capacities and desires, different 'spaces' to negotiate belonging to one or multiple spaces of embeddedness can be identified. Within these spaces of negotiation, agency takes place through a variety of strategies. Involuntary returnees often choose to comply with the limits of the structures with which they are confronted. Voluntary returnees, on the other hand, are embedded in multiple structures between which they are transnationally mobile. This means that they have increased room to manoeuvre, and can form hybrid identities, which allows them to apply creative responses to new situations in their personal lives (Sewell 1992, Emirbayer and Mische 1998, Bakewell 2008, Mai and King 2009).

Despite the fact that all returnees can display agency over their personal choices, each 'space of negotiation' has a potential obstacle to mediating between cultures or negotiating structural change. First, 'transnational European' returnees do not need to reconcile different spaces of belonging. Second, 'transnational in-between' returnees try to reconcile these fundamentally different value systems, but are almost never successful in doing so, while 'uni-local in-between' returnees are unable to carry out 
this reconciliation. Third, 'transnational Afghan' returnees do not want to reconcile multiple spaces of belonging. Fourth, 'uni-local Afghan' and 'failed European' returnees are both unable and unwilling to reconcile value systems. The expectation that return migrants can mediate between cultures and negotiate change in existing structures (Portes 1999, Sørensen, Van Hear, and Engberg-Pedersen 2002) is therefore overstated, and should be carefully formulated in policies on migration and development. 
In their footstep travels an invisible company of fathers, mothers, brothers, sisters, uncles and aunts and cousins. All hope is based on them. They are the pioneers' breed (...) they will survive everything.

Tommy Wieringa - Dit zijn de namen (These are the names, my translation), p. 101. 


\title{
8
}

\section{Returnees for change?}

\author{
Afghan return migrants' identification with the \\ conflict and their potential to be agents of change
}

\subsection{Introduction 1}

In the past decade, return migration from industrialized countries has been included in the policy and academic debate on the linkages between migration, development and peace-building, which expects two rather contradictory things from returnees. First, returnees to 'post-conflict' societies are seen as the ultimate proof of peace and return to 'normality' (Malkki 1992, Black and Gent 2006, Stigter 2006). Second, such returnees are considered as agents of change who can contribute to development and peace-building in their countries of origin (King 1978, Chimni 2002, Bakewell 2008, 2010).

Three types of assumptions underlie the expectation of the development and peace-building potential of migrants: first, migrants to industrialized countries are believed to be positively self-selected. Second, they are expected to acquire skills, capital and ideas while abroad and, third, they are expected to combine multi-local identifications and to be mediators between cultures who can negotiate change (Potter 2005, Jones 2011). However, previous work has shown that migrants from conflict areas are often a complex and heterogeneous mix of people (Koser and Van Hear 2003, Cassarino 2004, Brinkerhoff 2011). First, not all returnees are members of an élite. Second, not all returnees benefit from their migration experiences. On the contrary, the migration experience seems to work as a stratifying factor, and some migrants return frustrated and impoverished (see chapter 6 and Van Houte, Siegel, and Davids 2014). Third, not all migrants can successfully negotiate belonging to or can mediate between cultures (see chapter 7 and Van Houte and Davids Forthcoming/b). These observations imply that some returnees are potential actors of change, while others are not (Carling 2004, Cassarino 2004, Black and Gent 2006, Brinkerhoff 2011).

Migration-development-peace-building policies not only assume the ability of migrants to negotiate change in often complex 'post-conflict' areas, but they also have specific expectations about the type and direction of the change to which migrants contribute. Although the expectation of change often remains under-defined (Bakewell 2008), it is implicitly tied to socio-economic modernization in which migrants implant innovation, a sense of progress, justice, democracy and human rights into the society of return (King 1978, Raghuram 2009, Castles, De Haas, and

\footnotetext{
${ }^{1}$ This chapter is based on: Van Houte, Marieke. Forthcoming 2014. "Returnees for Change? Afghan Return Migrants' Identification with the Conflict and their Potential to be Agents of Change". Conflict, Security \& Development 14(5):1-27.
} 
Miller 2014, 79). In addition, change is expected to take place within existing (political) frameworks (Raghuram 2009).

This chapter first discusses the assumptions that underlie the expectation that return migrants can be agents of change in development and peace-building in the country of origin. I then focus on the case of Afghanistan, highlighting the challenges of 'post-conflict' Afghanistan and deconstructing the kind of change that is expected from returnees to this context. Thereafter, I take an emic approach to the life histories of 35 Afghans who returned from European countries to Kabul, ${ }^{2}$ to explore the way these histories are related to the conflict. Research shows that the motivation for return is of great importance for the post-return experience (Cassarino 2004, see chapter 3 and Van Houte and Davids 2008). I therefore explicitly compare voluntary returnees, who had the legal right to stay indefinitely in the country of destination, and involuntary returnees, who returned without such a status (see chapter 5 and Van Houte, Siegel, and Davids Forthcoming).

From this empirically grounded analysis, four ways in which returnees relate to the conflict become apparent: physically, institutionally, psychologically and with regard to the future. Coming back to the expectations raised in the migrationdevelopment-peace-building debate, I find that the only returnees who could potentially live up to any of these expectations are voluntary returnees. In contrast, involuntary returnees were in no way potential contributors to Afghan peace-building and development. I conclude that if any individual returnee's involvement is to begin to bring about change in the extremely complex issues of development and conflict in Afghanistan, the human dimension is essential. In addition, continued transnational mobility is migrants' strongest asset to overcome constraints and carefully negotiate change, rather than a weakness that implies their fluid commitment.

\subsection{Return migrants as agents of change?}

The discussion on return migrants' positive or negative relationship with development or peace-building focuses on roughly three types of characteristics that are ascribed to migrants, which I will discuss below: first, the characteristics based on the self-selective process of migration; second, their accumulated skills and savings in the host country; and third, their presumed multi-local identifications.

\subsubsection{Self-selective process of migration}

A first line of argument centres around the thought that migrants are positively selfselected, in a number of ways, which implies that their return is an inherently positive thing. A first characteristic arising from self-selection is that migrants from conflict areas who have the means to travel to industrialized countries are often members of 'functional élites' from a professional middle class, who are highly educated, relatively wealthy and strongly networked. Their return assumes an input of investments, skills and networks, which can be a significant factor in stimulating economic growth as a

\footnotetext{
2 Chapter 2 describes the methodologies used in this study.
} 
means to counter dependency on foreign capital and humanitarian assistance (Jazayery 2002, Long and Oxfeld 2004a, Zunzer 2004, Rostami-Povey 2007). However, while the first departures from a conflict area often represent the highest classes of society, later 'waves' of migrants are people of more modest descent who, although they are not the poorest of the country, spend much of their savings and belongings on the journey (see chapter 6 and Van Houte, Siegel, and Davids 2014).

The second argument based on self-selection is that migrants who take a risk in travelling long distances in search of safety and better opportunities are more entrepreneurial than the non-migrating population. Upon return, such an attitude can be in striking contrast to that of other people in war-torn and poor countries, and these returnees can act as dynamic role models (Cochrane 2007, Binaisa 2011). In addition, these returnees who are willing to take risks may become 'wartime entrepreneurs' who take advantage of monopoly positions to set up businesses. While such wartime entrepreneurship may contribute to the rebuilding of the economy, it may also slide to the criminal side, where profiteers, economic criminals and warlords reside (Cramer and Goodhand 2002, Zunzer 2004).

The third argument of self-selection is based on the assumption that migrants who left the country when it was in a state of conflict and crisis have a strong link to the country of origin, which may translate into a desire to help the country. However, it is also argued that having been away from the daily reality of the conflict, they may have developed uncompromising attitudes that strain rather than promote constructive conflict resolutions (Collier and Hoeffler 1998, Portes 1999, Lyons 2004, Zunzer 2004, Sherrell and Hyndman 2006, Lindley 2007, Bloch 2008). In addition, the political, social, economic and cultural implications of the return of such heavyweights' who have resided outside the country for decades should not be taken lightly, as they may shift the balances of power (Long and Oxfeld 2004a, Zunzer 2004). Their return may be seen by the government of return as a political action (Shindo 2012), while distrust between returnees and people who stayed in the country during the conflict may add to tensions in society (Zunzer 2004).

\subsubsection{Accumulation of capacity in industrialized countries}

The second line of argument is based on the knowledge, skills, savings and ideas that migrants can obtain while living in industrialized countries. Return migrants are expected to invest these material and immaterial capacities to benefit the development of the country of origin (Al-Ali, Black, and Koser 2001, De Haas 2005, Kent 2006, Sherrell and Hyndman 2006, Bloch 2008). In addition, Western-educated Afghans who are committed to principles of democratic dialogue may possess more reconciliatory attitudes, and may contribute to peace-building when they return and engage in public debate (Zunzer 2004, Brinkerhoff 2011). However, when 'Western', secular or 'modern' attitudes are not evaluated positively by the community of return, this may create issues of trust, hostility and resentment (Portes 1999, Cochrane 2007).

In addition to their normative evaluation, whether migrants accumulate skills and savings while abroad and whether they can transmit positive values to the country of origin strongly depends on legal status and living conditions in the host 
country (Zunzer 2004), and these are not equally distributed among different types of migrants. Not all returnees benefit from their migration experience. On the contrary, some migrants return frustrated and impoverished (see chapter 6 and Van Houte, Siegel, and Davids 2014). Increased socio-economic (individual or regional) differences caused by migration may increase tensions rather than contribute to stability (Zunzer 2004). In addition, returnees who strain existing resources and employment opportunities may cause resentment among the local communities (Long and Oxfeld 2004a).

\subsubsection{Multi-local identifications}

The third line of argument is inspired by the notion that integration into receiving societies and commitment to origin societies are not necessarily substitutes but can be complements, creating multi-local identifications of migrants and return migrants (De Haas 2010, see chapter 6 and Van Houte, Siegel, and Davids 2014). This leads to the expectation that, first, migrants can mediate between cultures, combining 'Western' knowledge, skills and ideas such as efficiency, democracy and transparency with their involvement in their communities of origin, where they have the networks, understanding of the context, and sense of belonging that are necessary to transfer these 'Western' assets (Potter 2005, Kent 2006, Jones 2011). Second, it is expected that their 'in-between' position of being insiders and outsiders at the same time makes them more independent from the constraints of structures, giving them the freedom to negotiate change (Portes 1999, Sørensen, Van Hear, and Engberg-Pedersen 2002, Brinkerhoff 2011).

However, earlier work shows four reservations regarding these expectations (see chapter 7 and Van Houte and Davids Forthcoming/b). First, returnees who can maintain long-term transnational ties and are transnationally mobile do not always need to reconcile different spaces of belonging, if they can meet different needs in different spaces of embeddedness. This also means that they do not necessarily need to return permanently to contribute to the country of origin. Second, returnees who do try are not always successful in reconciling sometimes fundamentally different value systems, since individual actors have limited agency to overcome structural constraints (De Haas 2010). In contrast, it has been argued that their real potential needs to be organized within existing structures (King 1978), and that the development of basic security and economic growth is a prerequisite for the participation of migrants. Rather than initiating change themselves, they may reinforce these positive trends with their investments and return (Cramer and Goodhand 2002, De Haas 2010). Third, not all returnees want to reconcile value systems: they may exclusively negotiate belonging to the country of origin. Fourth, returnees who return involuntarily and are involuntarily immobile after return are unable to reconcile discourses, because they cannot maintain ties with their former host country (chapter 7 and Van Houte and Davids Forthcoming/b).

From this literature review, it appears that if returnees contribute to development or peace-building, this will be only under very specific circumstances, and that each expectation of returnees' potential may also have a darker side (Black and Gent 2006, Brinkerhoff 2011). In addition, we can only understand the meaning of 
return if we take into account the context of the country of return (Shindo 2012). Since the literature on the migration-development-peace-building nexus has so far mainly focused on case studies from Africa and the Balkans, I will first discuss the current challenges of the Afghan conflict, before trying to determine what kind of 'change' is expected from Afghan returnees.

\subsection{Challenges of 'post-conflict' Afghanistan}

Migration is a phenomenon that has always been part of Afghan society, although it has taken place under continuously changing circumstances (see chapter 4). The conflicts of the past 35 years, starting with the invasion of the Soviet Union in 1979 and continuing through the Cold War, the civil war, Taliban rule and the War on Terror, have increased the number of Afghans abroad to an unprecedented level. In this context, migration has become a key survival and livelihood strategy in the Afghan way of life (Cramer and Goodhand 2002, Turton and Marsden 2002, Rubin 2006, Monsutti 2008, Oeppen 2009).

Three decades of violence destroyed and reshaped Afghan infrastructure on all levels. While Afghanistan has traditionally been a weak central state, the structures that existed were destroyed during these conflicts (Rubin 2002). Physically, agriculture and homes have been destroyed several times. Economically, there is widespread poverty and unemployment and a lack of goods and production. Socially, entire generations have grown up in exile without the notion of peace or security (Cramer and Goodhand 2002, Özerdem and Sofizada 2006, Rubin 2006, Suhrke 2007). In addition to destroying previously existing institutions and economies, decades of war have also created informal, wartime economies and institutions (Cramer and Goodhand 2002). The production of poppy and opium and the affiliated drug trade was a dominant area contributing to a 'black economy', controlled by warlords. The central government has failed to achieve a monopoly of violence, which causes a threat to security (Özerdem and Sofizada 2006, Mac Ginty 2010).

In the post-Taliban era, the international community launched a highly ambitious reconstruction programme, which required radical social change. Like many previous post-war reconstruction programmes, it was not merely about repairing what was broken, but entailed a broader modernization and state-building project. It covered the introduction of the rule of law, human rights and gender issues, liberal democratic institutions and elections, civil society and an open economy with market-based economic growth and access to education (Cramer and Goodhand 2002, Özerdem and Sofizada 2006, Suhrke 2007, Mac Ginty 2010). Local ownership of these programmes was, according to Suhrke, characterized by 'their' ownership of 'our' ideas (Suhrke 2007).

It has been argued that these post-conflict modernization programmes showed little attention for and was sometimes inherently contradictory to the complex, context-specific and historical processes in which the Afghan conflicts are rooted. In particular, the earlier negative effects of modernization efforts on social cohesion, the aversion to foreign influence, as well as the war and the post-war legacy, have not been sufficiently taken into account. Therefore, after the first enthusiasm about the fall of the Taliban, the reconstruction effort met a great deal of resistance (Cramer and 
Goodhand 2002, Suhrke 2007, Mac Ginty 2010). One of the most prominent challengers of the modernization project are the Taliban, who, after the initial years of relative peace, have launched an insurgency to regain power, declared their wish to free Afghanistan from infidel forces and to re-establish an Islamic state (Collins 2011).

The year 2014 is expected to be a new turning-point in the history of Afghanistan. The planned withdrawal of international military forces is only one aspect of a multidimensional transition period that includes security, political, and economic challenges, which are inextricably linked (Koser 2014, see chapter 4). Most analysts consider the most plausible scenarios to be either a return to civil war or a violent take-over by one of the parties, while a movement towards peace does not seem to be a realistic option (UNHCR 2013c, Wolf 2013). However, there is also resistance from within Afghanistan to the idea that the country's fate is (again) in the hands of the international community (Koser 2014). Nevertheless, uncertainty over the future of Afghanistan, sharpened by international attention on 2014, makes public perceptions of security pessimistic and creates self-fulfilling prophecies, as it influences migration decision-making today (UNHCR 2013c, Koser 2014).

After having decreased in the first years of the post-Taliban era, the number of asylum claims in industrialized countries is again increasing. With 36,600 asylum claims, Afghanistan was the most important source country for asylum seekers in the industrialized countries in 2012. A specific group of new asylum seekers are Afghans who have worked with the international community after 2002, who fear reprisals from the Taliban (UNHCR 2013c). At the same time, return is ongoing. Afghanistan remains one of the top five countries of origin for IOM's Assisted Voluntary Return and Reintegration (AVRR) programmes from the industrialized countries. Also, there is a steady number of Afghans in industrialized countries applying for IOM's Return of Qualified Afghans programme for temporary placements (Koser 2014).

Mobility has been a fundamental coping and survival strategy throughout the history of Afghanistan and increasingly over the last 35 years (Koser 2014). The repatriation of refugees was seen by the international community as the ultimate proof of peace and of return to 'normality', and as a powerful message that the mission of the Western allies in Afghanistan and the War on Terror in general had been successful (Turton and Marsden 2002, Black and Gent 2006, Stigter 2006). It was expected that returnees from Western countries could act as agents of change in the 'post-conflict' society of Afghanistan. However, despite very specific expectations of the characteristics of migrants that could help them to bring about change, the understanding of the concept of change itself remains underdeveloped.

\subsubsection{What kind of change?}

Migration-development-peace-building policies do not only assume the ability of migrants to bring change to often complex 'post-conflict' areas; they also have specific expectations of the type and direction of the change to which migrants contribute. Although the nature of the expected change often remains under-defined (Bakewell 2008, Faist 2008, Raghuram 2009, Brinkerhoff 2011), it is clear that it is not just any change that is considered to be of added value. Table 8.1 provides an overview of the 
expected characteristics of returnees, their positive and negative aspects, and the Afghan context related to these expectations.

Table 8.1 Assumptions of return migrants' characteristics, impact and Afghan context

\begin{tabular}{|c|c|c|c|}
\hline Characteristic & Positive assumption & Negative assumption & Afghan context \\
\hline $\begin{array}{l}\text { Self-selected } \\
\text { Functional } \\
\text { élites }\end{array}$ & $\begin{array}{l}\text { Bring in capital, } \\
\text { networks and } \\
\text { knowledge. }\end{array}$ & $\begin{array}{l}\text { Return impoverished / } \\
\text { strain or extract } \\
\text { resources. }\end{array}$ & $\begin{array}{l}\text { A troubled history of } \\
\text { knowledge and } \\
\text { modernization from } \\
\text { abroad. }\end{array}$ \\
\hline $\begin{array}{l}\text { Entrepre- } \\
\text { neurial }\end{array}$ & $\begin{array}{l}\text { Dynamic role models, } \\
\text { dare to take risks, } \\
\text { rebuild economy. }\end{array}$ & $\begin{array}{l}\text { Dark side of 'wartime } \\
\text { entrepreneurs'. }\end{array}$ & $\begin{array}{l}\text { Devastated economy } \\
\text { and institutions; } \\
\text { corruption and } \\
\text { wartime economy. }\end{array}$ \\
\hline $\begin{array}{l}\text { Concerned } \\
\text { with } \\
\text { conflict }\end{array}$ & $\begin{array}{l}\text { Strong ties to country of } \\
\text { origin, want to help. }\end{array}$ & $\begin{array}{l}\text { Uncompromising } \\
\text { attitudes; shift in } \\
\text { balances of power. }\end{array}$ & $\begin{array}{l}\text { Different waves of } \\
\text { migration for different } \\
\text { reasons. }\end{array}$ \\
\hline $\begin{array}{l}\text { Acquired } \\
\text { skills }\end{array}$ & $\begin{array}{l}\text { Western skills, } \\
\text { knowledge, ideas } \\
\text { transferred through } \\
\text { local networks, } \\
\text { knowledge and } \\
\text { attitudes. }\end{array}$ & $\begin{array}{l}\text { Input of 'different' } \\
\text { ideas creates hostility } \\
\text { or trust issues. }\end{array}$ & $\begin{array}{l}\text { Ambivalent attitudes } \\
\text { and distrust of } \\
\text { 'Western' reform and } \\
\text { culture. }\end{array}$ \\
\hline $\begin{array}{l}\text { Multi-locally } \\
\text { embedded }\end{array}$ & $\begin{array}{l}\text { Mediators between } \\
\text { cultures; more } \\
\text { independence from } \\
\text { national structures. }\end{array}$ & $\begin{array}{l}\text { Not all returnees } \\
\text { willing or able to } \\
\text { mediate or change } \\
\text { structures. }\end{array}$ & $\begin{array}{l}\text { Differences between } \\
\text { 'Afghan' and 'European' } \\
\text { values hard to } \\
\text { reconcile. }\end{array}$ \\
\hline
\end{tabular}

This overview shows that, implicitly, the positive notion of 'change' is tied to socioeconomic modernization, in which migrants introduce innovation, a sense of progress, justice, democracy and human rights into the society of return (King 1978, Raghuram 2009). In addition, change is expected to take place within existing (political) frameworks. Independence movements, power shifts, political unrest, religious-based opposition and illegal activities are not the kind of change for which policy makers are hoping. In particular since the events of 11 September 2001, the start of the 'War on Terror' and the recent developments of young Muslims travelling from Europe to Syria and Iraq to join Jihad movements, there is a heightened awareness that migrants can also contribute to the 'wrong' kind of change (Horst 2008, Raghuram 2009, Brinkerhoff 2011). The idea that migrants can and should be steered in the nature of their actions raises ethical and practical questions (Raghuram 2009).

Furthermore, Table 8.1 highlights that, in the context of Afghanistan, being an agent of change as a returnee is not an easy task. Even if returnees have adopted knowledge, skills and attitudes in the 'West', a history of resistance and distrust towards modernization will make it difficult to implement these in Afghanistan. Instead, these new skills may be seen as harmful by the local community and may increase tensions (Zunzer 2004). In addition, some returnees might be tempted to use 
their skills to make money in practices that are considered to be harmful or to involve negative change.

Hammond $(1999,243)$ argues that the operative principles of social change are construction, creativity, innovation and improvisation. (...) New rules of social change are being invented in an accelerated process of community formation'. This implies that while we can formulate hypotheses on returnees' contribution to change, we cannot predict the nature of this contribution, and have to look at the context of the country of return to understand returnees' behaviour. In the remainder of this chapter, I will take an emic perspective to discuss the way returnees to Afghanistan identify with conflict and what this means for their potential contribution to 'change'.

\subsection{Identification with conflict and potential to be agents of change}

From the empirically grounded analysis, four ways in which returnees relate to conflict stand out, which will be discussed here: physically, institutionally, psychologically and with regard to the future. Research shows that different types of migration experiences lead to different motivations for return (see chapter 5, 6 and 7 and Van Houte, Siegel, and Davids 2014, Forthcoming, Van Houte and Davids Forthcoming/b). A strong pattern that emerges is that élite and middle class Afghans, who had been able to leave in an early stage of the conflict, obtained refugee status and, eventually, permanent residence status in the host country. They returned voluntarily while having the ability and the right to re-emigrate if necessary. Afghans of more modest background left later, or took longer to reach Europe, and more often returned involuntarily after failing to obtain permanent status. Previously existing socio-economic differences were thus reinforced by the migration experience, which resulted in strongly differentiated patterns of post-return embeddedness and transnational mobility (see chapter 6 and Van Houte, Siegel, and Davids 2014). This in turn strongly influenced returnees' agency to apply flexible, inventive and critical responses to new situations, although this did not mean that they could easily change structures (see chapter 7 and Van Houte and Davids Forthcoming/b). This section explores how these differences among returnees are reflected in their identifications with conflict.

\subsubsection{Physical: personal security}

The first and most urgent confrontation with the conflict after return related to personal security issues. All returnees considered Kabul to be a highly unpredictable environment, where becoming involved in generalized violence such as a bomb blast, a shooting or a suicide attack was a real risk. However, the attitude towards these risks differed substantially. Voluntary returnees' multi-local embeddedness and transnational mobility meant that they could protect themselves better against 
generalized violence and leave Afghanistan whenever necessary. Faisal, 3 who returned voluntarily from the Netherlands, felt protected by his status and income as an advisor to a ministry of the Afghan government, which enabled him to live in a safer neighbourhood, take security measures, and drive using private transport. In addition, his ties to the Netherlands through his Dutch citizenship gave him protection and the ability to leave the country whenever necessary:

\begin{abstract}
If something happens for sure I'm sure that the embassy of Netherlands will help us immediately (...). And they're aware of everything, our accommodation, our office, and also we are under the protection of Dutch government in embassy. That is the main issue for us. That is why we are feeling comfortable here.

- Faisal (voluntary returnee (m), interview, original in English)
\end{abstract}

By contrast, involuntary returnees' weak embeddedness and involuntary immobility gave them a very insecure feeling that they were 'stuck' in a highly unstable situation. Jamal, an involuntary returnee from Norway, highlighted the inability to protect himself from potential violence:

When I'm going out from my home, I am saying OK, it's the last day, I cannot go back alive. Because you don't know if you are in the street, there will be something. You don't know that. Because you cannot get guarantee of which road will be safe. But it's every day the same. You think it could be the last day, last day.

- Jamal (involuntary returnee (m), interview, original in Dari, via translator)

In addition to their transnational mobility, voluntary returnees also seemed more mobile within Afghanistan. Unlike involuntary returnees, who said that travelling outside of Kabul was unsafe because of Taliban domination or violence in their region of origin, some voluntary returnees did occasionally travel into the provinces for work or to visit their properties.

Few returnees mentioned pre-migration issues as a personal risk factor after return, apart from two involuntary returnees who said that they feared a confrontation with their former enemies, and two others who mentioned their Hazara ethnicity as a risk factor if the Taliban were to regain power. Apart from that, ethnicity was remarkably absent from returnees' narratives, and returnees instead highlighted class to describe their position in society. This is in line with other observations that, in Afghanistan, ethnicity is of less importance than class (Zunzer 2004).

A larger number of voluntary and involuntary returnees mentioned that the fact that they had returned from a Western country was a factor in being a target for violence. First, they highlighted the fact that anti-Western groups such as the Taliban saw them as non-Islamic and betrayers. Second, they felt that greed, jealousy and distrust could make them a target for kidnapping. For example, Ajmal, an involuntary returnee who had successfully rebuilt his business after return, said he was afraid that his neighbours would inform the Taliban about his migration history because they were jealous of his business.

\footnotetext{
${ }^{3}$ To protect the privacy of the participants in this study, all names are pseudonyms. For the same reason, details such as towns or countries of residence are sometimes intentionally unspecified.
} 
If I go to the provinces and if I get arrested by the Taliban and if they find out that I was in Holland for six years, do you think they will let me go? No way.

- Ajmal (involuntary returnee (m), interview, original in Dari, via translator)

Returnees who worked with international organizations, or were economically very successful, were even more aware of this exposure. For voluntary returnees, this was sometimes a reason to leave Afghanistan after some time.

After two years it starts to be unsafe for me here. (...) people know that when they put a gun against my head, that daddy will pay a hundred thousand. And he will.

- Amir (voluntary returnee (m), interview, original in Dutch)

Next to their personal security, many returnees found the responsibility for their spouses and children even more important. Voluntary returnees who had left their families in the European country of residence found much comfort in the fact that they were only responsible for their own safety without risking everything they had gained by migrating. Fahima, who left her husband and children in Europe and went to work in Afghanistan, said:

I don't want to bring my children in danger. Because (...) I paid for that a lot. For that situation that my children have right now. (...) Nobody dares to come back to Afghanistan with their children. Even me. I can come alone. But not with everybody. And now they are in Holland and they continue their life.

- Fahima (voluntary returnee (f), interview, original in English)

By contrast, many involuntary returnees described the responsibility for their wife and children who lived with them in Afghanistan as a burden. Ajmal said:

I'm not really worried about getting killed or dying or whatever, one day you're born and the other day you just die. I'm not really worried about that. But the only thing I'm worried about is my kids. And my wife. So. If I get killed what will happen to them.

- Ajmal (involuntary returnee (m), interview, original in Dari, via translator)

Exposure to danger as a means of belonging

All returnees considered violence as a part of life in Afghanistan, and most tried to protect themselves from violence as much as they could. However, a number of young voluntary returnees seemed to treat exposure to danger as a means to negotiate belonging to Afghan life. For example, Eshan said he had changed his living conditions from a highly secured house for expatriate workers to a normal apartment without security walls or guards as part of his desire to be more part of the 'real' Afghan life. He explained:

What I can tell you is now that I'm happy. To be in Afghanistan. (...), I'm feeling totally well I'm not thinking about the security issues or what could happen or, I'm going to a house where everything can happen you know, Talib guy can show up and 
say you're kind of this guy is coming to Afghanistan, and you're not Afghans I have to shoot you because you're drinking alcohol, like it happened in Qargha. ${ }^{4}$ But I feel good, I feel really good now.

- Eshan (voluntary returnee (m), interview, original in English)

In addition to negotiating belonging to Afghan life, these young returnees saw working in a high-risk environment as a professional rite of passage that would be beneficial for their careers. For example, Besharat told me several stories about how he had almost been kidnapped while on the road for his job. He stressed that his effort to work in the challenging environment of Afghanistan represented his ambition and passion for his work.

It's a risk, it's not easy. But you can do it when you love your work. That is again the bewijs (proof) of love of your hobby.

- Besharat (voluntary returnee (m), interview, original in English)

Salim, who lived in Afghanistan since 2008, explained:

At this moment you have, so to say, a big niche in the market. Later, when there's peace and everyone has returned, everyone can do many things, what will be the difference then. You want to have a first mover's advantage.

Researcher: Then you'll be a kind of pioneer?

Exactly, and then you'll have your roots much deeper in the land, a big network and the golden rule is of course, the higher the risk, the higher the profit (...). The risk is quite big, not only for your money but also for your life. And if you're in a business, you make a lot of money.

- Salim (voluntary returnee (m), interview, original in Dutch)

Salim saw himself and other returnees as pioneers. His reasoning followed the logic of wartime entrepreneurs, in the sense of taking advantage of a market with many opportunities and limited competition because of the physical and financial risk involved (Cramer and Goodhand 2002).

This section has shown different patterns in the way voluntary and involuntary returnees dealt with personal security issues. Voluntary returnees' multidimensional embeddedness and mobility gave them the confidence that they could protect themselves from generalized violence and at the same time keep their dependants safe in the Western country of residence. Although their high profile as successful returnees created a security risk, they found a sense of belonging in Afghan society by taking that risk. On the other hand, involuntary returnees felt much less able to protect themselves or their dependants against generalized violence even though, since they are less visible than voluntary returnees, they run less risk of being personally targeted.

\footnotetext{
${ }^{4} \mathrm{~A}$ few weeks before the interview, the Taliban had attacked a hotel at Lake Qargha, a popular recreational area for locals and internationals from Kabul.
} 


\subsubsection{Institutional: dealing with corruption as a structural consequence of the conflict}

The widespread corruption that is a major element of how the conflict shaped the (institutional) structures of Afghanistan was a frustration and a struggle for many returnees. Becoming involved in politics or bureaucratic procedures was considered to be opaque, time consuming, costly and risky. The respondents showed three types of strategies for dealing with institutional structures: changing, avoiding and rejecting. Changers were returnees who wanted to combine their European higher education, working experience and ideas with their identification with Afghanistan and their desire to reclaim an influential (political) position. They tried to change institutions from within, which is exemplified by Shafiq:

I can bring change. I fight corruption, bureaucratics, an overload of paperwork. I want to ease up the system, going to a European system.

- Shafiq (voluntary returnee (m), interview, original in English)

This strategy, however, met a great deal of resistance. Shafiq found that his mission to transform his ministry to meet European standards added to the distrust that already existed among local Afghans towards Afghans who had returned from Western countries.

They say you are a European spy or a Western spy or a British spy, who doesn't take into account the interests of Afghanistan.

- Shafiq (voluntary returnee (m), interview, original in English)

Since this strategy required both European education and work experience and a link to the Afghan political class, and also entailed a personal risk, only a small number of multi-locally embedded voluntary returnees attempted to follow it. For those who did not pursue a political career, a common strategy among both voluntary and involuntary returnees was to avoid the institutional structures as much as possible. This is illustrated by Samir, who had his own construction company and practised the proverbial strategy of 'see no evil, hear no evil, speak no evil' as he tried to do his business:

All the people who work for the government are not good people. (...) Well. I don't respond (giggles) at all. I don't hear anything (giggles). And I don't see anything (laughs).

- Samir (involuntary returnee (m), interview, original in Dutch)

Many young voluntary returnees avoided the corruption in local institutional structures by looking for working environments that were at a greater distance from these structures, such as private companies or international NGOs. With their European education and language skills, they could access these jobs, which were highly paid and more open to alternative attitudes and skills, more easily (Ammassari 2004, Shindo 2012). Within these more enabling structures, they could still see 
themselves as professional role models who could show different, more efficient or more transparent ways of working, as Besharat said:

The people who come back to Afghanistan should really make the change, because here they have the traditions that are not of this time anymore. We can change them, teach different things.

- Besharat (voluntary returnee (m), interview, original in English)

However, in this sector, too, it was not easy to avoid corruption. Zafar, who worked for a private construction company set up by returnees, felt that structural constraints first needed to be improved before he could be of added value.

My aim was to help reconstructing Afghanistan. It is not the time yet. (...) Politics have to be good first. It has to be quiet. People need to have security. They don't have that.

- Zafar (voluntary returnee (m), interview, original in Dutch)

Last, many involuntary returnees who were frustrated by their inability to maintain institutional ties with both their former host country and Afghanistan responded by rejecting the institutional structures. While they often rejected the 'Western' system altogether, considering it to be harmful and incompatible with Afghan culture (chapter 7 and Van Houte and Davids Forthcoming/b), many of these returnees were also angry and disappointed with the Afghan government, which they felt was too weak to support its citizens.

The government is the one who can help people. Although the government is receiving a lot of money from different countries, and their pockets are full of the money, still they don't help the people.

- Omar (involuntary returnee, interview, original in Dari, via translator)

Confronted with the corruption that was a structural consequence of the conflict, returnees showed three types of strategies, each of which had their challenges. Changing the structure by actively fighting corruption proved difficult for someone who was subject to the same structure, and met with great resistance that could result in personal danger (Wijers 2013). Having the ability to leave the country quickly helped to follow this strategy. Avoiding the structure by finding employment in a more enabling working environment only partially worked because corruption was an allencompassing element in Afghan life, although having access to employment in the international community did help to avoid issues of corruption. Rejecting any institutional involvement was a response to exclusion rather than a strategy. In conclusion, none of these respondents could effectively overcome the structural constraints of corruption in Afghanistan, although multi-local embeddedness and transnational mobility helped returnees to deal with it. 


\subsubsection{Psychological: mental health and culture of conflict}

Decades of continued violence in which entire generations have grown up without the notion of security have affected the mental health of Afghans. Many respondents noticed a change among those who had lived in Afghanistan or in the neighbouring countries throughout the conflict. They mentioned aggression, loss of cultural values and an inability to plan for the middle- or long-term as an effect of life in insecurity.

People have become very aggressive here. Even on the street. This is not strange because 30 years of war, you don't know anything else, just war. It 'works' on you, so to say. Unconsciously you are changed.

- Zafar (voluntary returnee (m), interview, original in Dutch)

Among returnees from Europe, contrasting trends can be identified with regard to mental health. Respondents who were not accepted as refugees and who lived in Europe as asylum seekers with temporary asylum status, or as undocumented migrants, were negatively affected by the limited rights and enforced passivity this type of life meant (see also chapter 3). Despite being outside the war zone, their migration experience was yet another episode of insecurity in their lives. Their involuntary return affected their dignity, self-worth and sense of control over their lives. Mahboob evaluated his life as follows:

To tell you the truth from the time that I remember (...) we just raised up with war and I remember all the wars in my head and I just grew up with headaches and with a lot of problems.

- Mahboob (involuntary returnee (m), interview, original in Dari, via translator)

Although these migrants once had the strength to take fate into their own hands and to travel all the way from Afghanistan to Europe, they now presented themselves as victims without much agency in the course of their lives. When asked what should be done to turn things in Afghanistan in a positive way, Omar said:

Well it's out of the hands of the human people of Afghanistan. If God does a favour to us, who knows.

- Omar (involuntary returnee (m), interview, original in Dari, via translator)

By contrast, voluntary returnees who had been recognized as refugees and had been given a permanent residence status had had the opportunity to build up a stable life in which they could receive education and concentrate on family affairs, personal development and leisure activities. This experience seemed to have given them a mental strength, energy and confidence, as was displayed by Salim, Besharat and Eshan in the previous examples. In addition, they were aware of these differences. Compared to involuntary returnees and the local population, they felt privileged and better equipped to deal with challenges (see also Cochrane 2007, Binaisa 2011), as Eshan explained: 
They grow up in the war and they spent most of their time in countries like Pakistan, where in Pakistan as an Afghan, you're not accepted because you are an Afghan. And (...) you come with this old behaviour and feelings back to your country and see that everything is destroyed. And you have got the opportunity to make a lot of money but you have to lie (...) you have to say ok, I'm doing this because I wanna survive. (...) And I'm not judging because, I'm not in this position I was somewhere far in a, in a country where I had everything. You know, education, clean system, money everything was there. So I cannot come back to this country and judge them.

- Eshan (voluntary returnee (m), interview, original in English)

While living in constant insecurity for much of their lives had affected involuntary returnees' mental health, voluntary returnees came with an optimism, energy and pro-active attitude that were new inputs into Afghan society. Although voluntary returnees also faced the many obstacles and frustrations of life in Afghanistan, they felt physically and morally better equipped to deal with these challenges. This is potentially an important contribution to the conflict-ridden environment of Afghanistan.

\subsubsection{The future: stay or go?}

Although life in Kabul was unstable in 2012, returnees found that the main security concerns for Afghanistan related to the future. All returnees expected the gradual withdrawal of the international military and civil presence after 2014 to lead to either a return of the Taliban or a return to civil conflict. Although migration has always been a means for Afghans to deal with problems such as conflict, violence and economic crisis, for people who have migrated before, the barrier to leaving seems to be even lower. Therefore, the question 'can returnees be agents of change?' can also be followed by '... and for how long?'

The future looks very different for voluntary and involuntary returnees. Involuntary returnees' involuntary immobility in the context of the unstable security situation of Afghanistan had a strongly disempowering effect (Carling 2002, see chapter 6 and Van Houte, Siegel, and Davids 2014). When asked for their outlook for the next five years, involuntary returnees presented a very dark perspective for their own lives and the future of Afghanistan. By contrast, voluntary returnees' continued transnational mobility was an important prerequisite for their voluntary return in the first place, which made them feel comfortable enough in the unstable Afghan environment. Those characteristics also enabled them to carry out a constant reevaluation of their decision to stay, return or move elsewhere, as Salim said:

These people have the advantage that they can always leave again. So therefore they can easily come back. That is a great advantage, (...). Because I like to come and work here, not because it's that safe here, but because you can mean a lot. And that gives a lot of satisfaction for your work. And when it goes bad then I'm out again.

- Salim (voluntary returnee (m), interview, original in Dutch) 
The main potential reason for re-emigrating from Afghanistan was a deterioration in the general security situation. Most voluntary returnees therefore planned no further than 2014, and implicitly anticipated that they would leave by that time. In addition, a deteriorating personal security situation for successful returnees could also be a motivation to leave, as stated above by Amir. Last, a disappointing return experience arising, for example, from the inability to bring change to the structural problems in society, as displayed by Zafar above, was a motivation for some voluntary returnees to leave Afghanistan.

The tendency of voluntary returnees to leave after a few months or years has stigmatized them. They have a reputation for coming to Afghanistan to make quick money without investing in the reconstruction of the country, and for leaving as soon as the situation becomes difficult. This is also expressed by some involuntary returnees:

They have the passport of those countries, they are citizens and they are basically Americans or Canadians or Europeans. (...) And whenever the security or the situation gets bad in Afghanistan then they just sit in the plane and leave the country and they have a safe future there.

- Kamal (involuntary returnee (m), interview, original in Dari, via translator)

Although voluntary returnees' mobility may be considered a weakness in their potential to contribute to change, it is also a valuable asset, since it allows them to be different from the dominant society. Wahid, who worked for an NGO on women's rights, explained:

Sometimes I find people who say, well you are so sure because you have a [Dutch] passport in your pocket. Yes. Maybe is true. It gives me courage to do something. I know, for example, an Afghan never wants to come (...) to fight for women's rights. But I do it. (...) And perhaps that courage is that I'm also Dutch. I have the courage that if something happens, well I say OK, if you don't want me, then I don't want you either. But an Afghan could never say something like that. If they say 'I don't want you', then what?

(...)

When I say to someone that I have Dutch nationality and they look at me, oh you are a Westerner. No, I'm not Westerner, I am Afghan. They say you are not Muslim. I say yes I am Muslim. [They] say why talk about women's rights. [I say] why not? He said no no that comes from other countries to us. That is a little bit hard. That is why when I go to the villages of Afghanistan or Kabul I don't say I come from another country or from the Netherlands or I have been to the Netherlands. Then I try to say I am an Afghan I have never been outside of Afghanistan.

- Wahid (voluntary returnee (m), interview, original in Dutch)

Wahid's multi-local embeddedness and transnational mobility allowed him to be an insider and an outsider at the same time (Salih 2002) in a delicate negotiation between Afghan, Muslim and Western identities. By presenting himself as an Afghan and a Muslim and concealing his Dutch citizenship, he was able to increase his credibility and to introduce new ideas on women's rights. At the same time, his Dutch 
citizenship and his mobility gave him the courage to make controversial statements that deviated from the views of the dominant society, knowing that in this explosive field of cultural values, political interests and religious mandates he had an escape route.

While involuntary immobility had a paralysing effect on involuntary returnees in the light of the expected post-2014 changes, voluntary returnees chose to return to Afghanistan despite these expected changes. Although they are likely to re-emigrate in the face of '2014', this very mobility also allowed them to take the risk of being different from the dominant society. Rather than a weakness, their mobility is therefore their strongest asset that may facilitate their most valuable contributions.

\subsection{Conclusion}

This chapter interrogated the assumptions that underlie the expectation that return migrants can be agents of change in development and peace-building, and deconstructed the kind of change that is expected from returnees. The chapter then took an emic perspective to the life histories of 35 Afghan return migrants to explore the ways in which returnees identify with the conflict and the kind of 'change' they could potentially bring in the migration-development-peace-building nexus. I identified four ways in which returnees relate to conflict in Afghanistan: physically, institutionally, psychologically and with regard to the future. Using these empirically grounded findings, I will now come back to what these findings tell us about the expectations within the migration-development-peace-building debate, which state that they are positively selected, have picked up savings and ideas abroad, are able to mediate between cultures and are therefore potential agents of change.

The only returnees who could potentially live up to any of the expectations raised, are voluntary returnees, defined as those who returned while having permanent legal status to stay in their host country. These migrants returned while maintaining ties with their European country of residence. Their multi-local embeddedness and transnational mobility gave them the confidence that they could protect themselves from generalized violence and at the same time keep their dependants safe in the Western country of residence. While ethnic or other premigration security issues were remarkably absent in their narratives of security, their strong affiliation with the West and their sometimes high profiles as successful returnees created a risk for them. Younger voluntary returnees found a sense of belonging in Afghan society by taking that risk and fitted the profile of 'wartime entrepreneurs' in the positive sense of the term: they were pioneers who took advantage of the opportunities of a market with limited competition because of the physical and financial risk involved (Cramer and Goodhand 2002).

Many voluntary returnees were driven by ambition, and chose to return to Afghanistan despite the expected post-2014 turbulence. They returned with an optimism, energy and pro-active attitude, which was a new input into the conflictridden Afghan society. They adopted a discourse of modernization in which they saw their knowledge, skills and attitudes from Europe as an asset they could offer to Afghanistan. However, although they tried to negotiate 'in-between' practices of Western modernity in an Afghan context, any 'foreign' ideas were looked at 
suspiciously. Implementing such ideas required patience and social skills, which made few of these efforts to change existing structures successful. Voluntary returnees constantly re-evaluated their decision to stay or move, and they are likely to reemigrate in the face of the post- 2014 changes, which stigmatized them as pocketfillers. However, this very mobility also allowed them to take the risk of being 'different' from the dominant society, and to advocate controversial opinions that went against the current discourse, through creativity, innovation and improvisation, as Hammond (1999) defined social change.

In contrast, involuntary returnees, who returned without having any legal alternative that would permit them to stay, were in no way potential contributors to Afghan peace-building and development. Most of them were of more modest backgrounds and returned further impoverished and frustrated rather than enriched by their migration experience (see chapter 6 and Van Houte, Siegel, and Davids 2014). Being weakly embedded in Afghanistan and involuntarily immobile, involuntary returnees felt exposed to generalized violence, as they did not have the means to protect themselves and their dependants. However, their lower profile made them less of a target than voluntary returnees. Having lived but never really participated in their former host country, they had not picked up many skills or ideas; rather, they leaned towards the conservative and traditional side as a strategy for negotiating belonging to Afghan society (see chapter 7 and Van Houte and Davids Forthcoming/b). Having lived in constant insecurity for much of their lives and the expected increased insecurity after 2014, affected their mental health. Furthermore, their inability to maintain ties with their host country, in addition to their lack of embeddedness in the Afghan space, made them angry and disappointed, which compelled them to retreat from, rather than bring change in, society.

Two main conclusions can be drawn from these results. First, if any individual returnee's involvement is to begin to bring about change in the extremely complex issues of development and conflict in Afghanistan, the human dimension of that involvement is critical. Voluntary returnees' creativity, resilience and innovativeness, along with their entrepreneurial mentality and their intellectual skills, are valuable human inputs. Nevertheless, these aspects are relational, and it proved to be difficult for individual returnees to negotiate change in a society that is suspicious of modernization and 'foreign' involvement. In contrast, the human dimension of returnees who are impoverished, disappointed and frustrated by their migration experience and the role of the Afghan government and their European host country can also have a negative impact, as it feeds anti-Western sentiments that are already present in the environment of return.

Second, although the international community sees repatriation as the ultimate proof of peace, representing the restoration of normality, there is no such thing as a return to 'normal' in the context of Afghanistan, as the conflict and migration movements of the past 35 years have shaped the reality of today (Monsutti 2008). Rather, a prerequisite for Afghan returnees' contribution to change in Afghanistan is continued transnational mobility (Black and Gent 2006, Stigter 2006, Monsutti 2008). In the explosive environment of today's Afghanistan, transnational mobility is a strategy that allows migrants to become more independent of national structural constraints and to ensure their own safety. Transnational mobility is therefore their strongest asset for overcoming constraints and carefully negotiating change, rather 
than a weakness that implies their fluid commitment. Policies aimed at stimulating the migration-development-peace-building nexus should therefore no longer focus on putting migrants 'back in their place' (Bakewell 2008). 
I always read it as a tragic tale of Odysseus's struggle to find his way home. Now I understand more and more (...) that he wasn't lost, but that after the wonders he had seen, Odysseus couldn't, perhaps didn't want to, return home.

Daniel Mason - The Piano Tuner, p. 291. 


\section{9}

Conclusion

Moving back or moving forward?

\subsection{Return migrants as agents of change? ${ }^{1}$}

In this globalizing world, it has become common ground that development, security and mobility are interdependent. Return migration has come to be considered as a multi-tool with which industrialized host states can manage migration, defend domestic security and welfare and promote international development and peacebuilding (see Skeldon 2008). The paradoxical lines of expectation of return migration as both a movement back to normal and a movement forward to change have raised many questions to be explored.

In this thesis, I took a transnational and multidimensional approach to overcome the dichotomies, generalizations and empirical shortcomings that surround the understanding of return migration within the migration-development-peace-building nexus. I explored (1) the heterogeneity of the post-return experience, (2) the complex meanings of and motivations for return migration, (3) the hierarchization of returnees' mobility or immobility and (4) returnees' room to manoeuvre to negotiate between spaces of belonging, in order to (5) interrogate the expectations on which the link between return migration, development and peace-building is based. This exploration centred around the following main question:

Under what circumstances are migrants returning from industrialized countries willing and able to contribute to change with regard to development and peace-building in their 'post-conflict' country of origin?

I approached the question of the development potential of return migrants through an anthropological lens, in which the voices and experiences of migrants were analysed in a critical interrogation of the assumptions that inform host governments' migration policies. The study focused on the life courses of return migrants in a holistic approach to the complex reality of migration, while building on two methodologically complementary research phases. The first phase took a comparative mixed methods approach to the experience of 178 returnees in six countries across the world in order to explore general trends as well as context-specific issues in the field of return migration. The second phase built on this comparative work with an in-depth case study of 35 return migrants in Afghanistan that addressed the complexities of return. The narrative as a research methodology proved essential for unravelling this

\footnotetext{
${ }^{1}$ Parts of this chapter and of chapter 1 appear in Van Houte, Marieke and Tine Davids. Forthcoming/a.

"Moving Back or Moving Forward? Return Migration, Development and Peace-Building". Diversities.
} 
complexity and providing an empirically grounded alternative to the policy-oriented categorizations.

The concept of multidimensional and multi-local embeddedness was further developed and used as a transnational and multidimensional approach to the multisited experience of migration. Embeddedness, defined as the process of an individual's identification with and participation in one or multiple spaces of belonging, merges understandings of transnationalism and integration into one analytical framework. In addition, it highlights the interplay between agency and structure and addresses the need for an encompassing perspective taking into account complexity, contradictions and diversity while preventing conceptual vagueness. Below, I present the main findings of this study. After that, I discuss the contribution and policy implications of this thesis.

\subsection{Main findings}

Chapter 3 presented the results of the first comparative research phase, and chapters 5 to 8 were based on the in-depth Afghan case study. Each chapter answered one of the sub-questions of the study.

\subsubsection{Determinants of post-return embeddedness}

Chapter 3 investigated whether the use of Official Development Assistance (ODA) for 'Assisted Voluntary Return' (AVR) programmes for rejected asylum seekers and undocumented migrants is justified. It analysed the factors that influence post-return embeddedness, including return assistance, migration cycle experiences and the individual characteristics of the returnees in the six countries under study. The results highlight the universal difficulties faced by rejected asylum seekers and undocumented migrants with regard to building a sustainable livelihood, establishing social networks and having a sense of identity and belonging in the country of return. Returnees were often worse off in terms of access to independent housing and income than they had been before their migration.

The process of post-return embeddedness is determined by a wide range of factors. The study showed context-specific factors as well as remarkably strong general trends across the six very different countries of return. First, the obstacles and opportunities faced by returnees are directly related to previous experiences in the migration cycle. The living circumstances in the host country and the motivation for return are of critical importance for post-return embeddedness. Spending years in restricted circumstances that constrain freedom of movement, limit possibilities for employment and education and lead to dependency on social welfare damage migrants' self-esteem, survival skills and social networks. The limited return assistance that is provided cannot compensate for the damaging effects of these factors on the prospects for post-return embeddedness. Apart from business assistance, the return assistance therefore had limited or even negative effects on all dimensions of embeddedness. The human dimension of assistance and the incorporation of all dimensions of embeddedness seemed important. 
These findings show that it is unjustified and even misleading to suggest that AVR programmes may promote development. While the intention is expressed, and budget is assigned, to make this type of return migration contribute to development, this intention is undermined by restrictive migration policies. In contrast to the expectation for return migration and development, the returnees in this sample faced deprivation rather than benefits from their migration experience. As sustainable return is thus already a challenge for individual returnees, they cannot be expected to contribute to development. Instead, the opposite is true: returnees often represent a burden on their relatives' household budgets and put higher pressure on already limited employment, health care and education facilities in the country of return.

\subsubsection{Meanings of and motivations for return}

The conclusions in chapter 3 that return motivation, more than return assistance, is of crucial importance for post-return embeddedness, asked for a more thorough and qualitative analysis of the meanings of and motivations for return. Chapter 5 therefore proposed an encompassing analytical framework to deconstruct return as a complex decision-making process. This framework aimed to find an alternative to the confusing vocabulary and the unsatisfactory dichotomy between voluntary and involuntary return. A better understanding of the meanings of and motivations for return can help to address the needs and potential of returnees through improved policies.

The analytical framework builds on earlier theoretical approaches to migration, and combines the concepts of structure and agency with concepts of desire and capacity. Instead of providing deterministic understandings that predict the outcome of migration, this model shows the interaction between structures, capacities, desires and agency, in which all elements may be dynamic or contradictory. Agency can be seen as an actor's effort to match his or her desires and capacities, while being shaped by, and shaping, the structural context. In this mechanism, all actors can display some degree of agency over their actions, either through enhancing their capacities to meet their desires, or by redefining their desires to match their capacities. The framework has the potential to be used in any context of migration and non-migration, in any degree of (in)voluntariness and in changing circumstances. It may be seen as a template of the factors that should be taken into account in the study of migration, with the weight and direction of all linkages varying according to the research context.

In the Afghan case study, the analysis centred around the structural reality of changing migration policies and their impact on desires and capacities to return. The analysis shows that there are no clear-cut boundaries between voluntary and involuntary return (see also Monsutti 2008). Almost no return decision was entirely free, as there were legal constraints, family pressures, economic needs or sociocultural difficulties at the basis of this decision. Almost no return decision was entirely forced, either, as most people had an alternative, however harsh, to returning. There is, therefore, a gradual scale instead, which depends on social, economic, institutional and cultural capacities and desires, interacting with structures and leading to different levels of agency over the decision to return. 
Nevertheless, the analysis also shows that there is a strong empirical difference in the post-return experiences of returnees who have the capacity to be transnationally mobile and returnees who do not. Returnees who were unable to match their desires of mobility with their capacities, because of their lack of legal status in the former host country and stricter asylum policies, experienced involuntary immobility (Carling 2002). This caused a great deal of unrest and discontent, and a feeling that they were 'stuck' in a potentially explosive environment. By contrast, returnees who had permanent legal status in the host country returned while knowing that they would be able to re-emigrate if necessary (Castles and Miller $2009,68)$. This continued transnational mobility gave these returnees a crucial sense of security and comfort, and allowed them to take advantage of geographical differences (Carling 2002).

Mobility continues to be an essential desire in the lives of return migrants. I therefore propose to centralize mobility in the analysis of return. At the same time, I propose an alternative working categorization of voluntary and involuntary return. While pleading for the complexities of return to be taken into account, I challenge the current policy-oriented categories that are based on the use of force by defining the same categories in a more adequate and meaningful way. A distinction that captures the wide empirical differences in the post-return experience, and that is therefore more relevant for policy and research on migration, should be based on post-return mobility. Practically, this categorization is based on legal status in the host country: the return of a migrant who has a legal alternative to stay permanently in the European country of residence is called voluntary, while the return of a migrant without such a legal alternative is defined as involuntary. This working definition of voluntary and involuntary return was used in chapters 6,7 and 8 to interrogate the expectations of the characteristics of return migrants, which informs the debate on the linkages between migration, development and peace-building.

\subsubsection{Migration as reinforcement of socio-economic stratification}

Chapter 6 explored a new avenue of the hierarchization of mobility and social stratification (Castles 2007). It showed how socio-economic differences that existed prior to migration are reinforced by the migration experience, which results in strongly differentiated patterns of post-return embeddedness and transnational mobility.

The results of this chapter show that, contrary to the assumptions that underlie migration and development policies, not all migrants are members of élites, not all returnees benefit from their migration experiences and not all returnees are strongly multi-locally embedded. Instead, the opportunities that migrants have to accumulate skills, knowledge and savings in the host country, which they may invest after their return are unequally distributed among different types of migrants. Socio-economic differences that existed previously are reinforced by the migration experience, which results in strongly differentiated patterns of multi-local embeddedness and transnational mobility. This finding restricts expectations for return migration and development. 


\subsubsection{Negotiating belonging and change}

Chapter 7 focused on the 'human dynamics' of return and on the expectations within the migration, development and peace-building debate about returnees' potential to mediate between cultures and to negotiate change as a result of their multi-local ties and hybrid identities. The chapter explored how Afghan migrants returning from European countries negotiated belonging to one or multiple spaces of embeddedness through their expressions and practices of marriage, sexuality and gender norms.

The findings confirm that, rather than there being dichotomies between victims and agents, all returnees can be seen as agentic players who attempt to match their desires and their capacities. At the intersection of capacities and desires, different 'spaces' to negotiate belonging to one or multiple spaces of embeddedness can be identified. Within these spaces of negotiation, agency takes place through a variety of strategies. Involuntary returnees often choose to comply with the limits of the structures with which they are confronted. Voluntary returnees, on the other hand, are embedded in multiple structures between which they are transnationally mobile. This means that they have increased room to manoeuvre, and can form hybrid identities, which allows them to apply creative responses to new situations in their personal lives (Sewell 1992, Emirbayer and Mische 1998, Bakewell 2008, Mai and King 2009).

Despite the fact that all returnees can display agency over their personal choices, each 'space of negotiation' has potential obstacles for the mediation between cultures or the negotiation of structural change. First, 'transnational European' returnees do not need to reconcile different spaces of belonging. Second, 'transnational in-between' returnees try, but are almost never successful, while 'uni-local in-between' returnees are unable to reconcile these fundamentally different value systems. Third, 'transnational Afghan' returnees do not want to reconcile multiple spaces of belonging. Fourth, 'uni-local Afghan' and 'failed European' returnees are both unable and unwilling to reconcile value systems. The expectation that return migrants can mediate between cultures and negotiate change in existing structures (Portes 1999, Sørensen, Van Hear, and Engberg-Pedersen 2002) is therefore overstated, and should be carefully formulated in policies on migration and development.

\subsubsection{Return migrants' potential to be agents of change}

Chapter 8 interrogated the assumptions that that migrants are positively selected, have picked up savings and ideas abroad, are able to mediate between cultures and are therefore potential agents of change, which underlie the expectation that return migrants can be agents of change in development and peace-building. The chapter built on the previous four empirical chapters to answer the main question. The chapter deconstructed what kind of change is expected from returnees, and then explored the ways in which Afghan returnees identify with the conflict and what kind of 'change' they can potentially bring in the migration-development-peace-building nexus. I identified four ways in which returnees relate to conflict in Afghanistan: physically, institutionally, psychologically and with regard to the future. Using these 
empirically grounded findings, I considered how they address the expectations within the migration-development-peace-building debate,

The only returnees who could potentially live up to any of the expectations raised, are voluntary returnees. These migrants returned while maintaining ties with their European country of residence. Their multi-local embeddedness and transnational mobility gave them the confidence that they could protect themselves from generalized violence and at the same time keep their dependants safe in the Western country of residence. While ethnic or other pre-migration security issues were remarkably absent in their narratives of security, their strong affiliation with the West and their sometimes high profiles as successful returnees created a risk for them. Younger voluntary returnees found a sense of belonging in the Afghan society by taking that risk and fitted the profile of 'wartime entrepreneurs' in the positive sense of the term: they were pioneers who took advantage of the opportunities of a market with limited competition because of the physical and financial risk involved (Cramer and Goodhand 2002).

Many voluntary returnees were driven by ambition and chose to return to Afghanistan despite the expected post-2014 turbulence. They returned with an optimism, energy and pro-active attitude, and this was a new input into the conflictridden Afghan society. They adopted a discourse of modernization in which they saw their knowledge, skills and attitudes from Europe as assets they could offer to Afghanistan. However, although they tried to negotiate 'in-between' practices of Western modernity in an Afghan context, any 'foreign' ideas were looked at suspiciously. Implementing such ideas required patience and social skills, which made few of their efforts to change existing structures successful. Voluntary returnees constantly re-evaluated their decision to stay or move, and they are likely to reemigrate in the face of the post-2014 changes, which stigmatized them as pocketfillers. However, this very mobility also enabled them to take the risk of being 'different' from the dominant society, and to advocate controversial opinions that went against the current discourse, through creativity, innovation and improvisation, as Hammond (1999) defined social change.

In contrast, involuntary returnees, who returned without having any legal alternative that would permit them to stay, were in no way potential contributors to Afghan peace-building and development. Most of them were of more modest background and returned further impoverished and frustrated rather than enriched by their migration experience (see chapter 6 and Van Houte, Siegel, and Davids 2014). Being weakly embedded in Afghanistan and involuntarily immobile, involuntary returnees felt exposed to generalized violence, as they did not have the means to protect themselves and their dependants. However, their lower profile made them less of a target than voluntary returnees. Having lived but never really participated in their former host country, they had not picked up many skills or ideas; rather, they leaned towards the conservative and traditional side as a strategy for negotiating belonging to Afghan society (see chapter 7 and Van Houte and Davids Forthcoming/b). They had lived in constant insecurity for much of their lives and expected increased insecurity after 2014, and this affected their mental health. Furthermore, their inability to maintain ties with their host country, in addition to their lack of embeddedness in the Afghan space, made them angry and disappointed, which compelled them to retreat from, rather than bring change in, society. 
Two main conclusions can be drawn from these results. First, if any individual returnee's involvement is to bring change in the extremely complex issues of development and conflict in Afghanistan, the human dimension of that involvement is critical. Voluntary returnees' creativity, resilience and innovativeness, along with their entrepreneurial mentality and their intellectual skills, are valuable human inputs. Nevertheless, these aspects are relational and it proved to be difficult for individual returnees to negotiate change in a society that is suspicious of modernization and 'foreign' involvement. In contrast, the human dimension of returnees who are impoverished, disappointed and frustrated by their migration experience and the role of the Afghan government and their European host country can also have a negative impact, as it feeds anti-Western sentiments that are already present in the environment of return.

Second, although the international community sees repatriation as the ultimate proof of peace, representing the restoration of normality, there is no such thing as a return to 'normal' in the context of Afghanistan, as the conflict and migration movements of the past 35 years have shaped the reality of today (Monsutti 2008). Rather, a prerequisite for Afghan returnees' contribution to change in Afghanistan is continued transnational mobility (Black and Gent 2006, Stigter 2006, Monsutti 2008). In the explosive environment of today's Afghanistan, transnational mobility has become a strategy that allows migrants to become more independent of national structural constraints and to ensure their own safety. Transnational mobility is therefore their strongest asset for overcoming the constraints and carefully negotiating change, rather than a weakness that implies their fluid commitment. Policies aimed at stimulating the migration-development-peace-building nexus should therefore reconsider the focus on putting migrants 'back in their place' (Bakewell 2008).

\subsection{Conclusion and policy implications}

Return is neither a movement back to normal, nor is it easily a movement forward to change. When migrants return to their country of origin, they do not automatically contribute to development and peace-building. The relationship between migration and development is too complex for easy generalizations. Rather than formulating dichotomies, the policy and practice of migration would benefit from highlighting the complexities of migration. By unfolding the meanings of and motivations for return migration, and comparing voluntary and involuntary returnees, this study has identified contradictions in return migration policies. Inclusive methodologies focusing on the meaning migrants give to their migration experiences have provided a better understanding of return and migration patterns. After exploring the stories of return migrants and the complexity of return migration, I now discuss the contribution of this thesis to the debate on the linkages between return migration, development and peace-building, and the policy implications that arise. 


\subsubsection{Contribution of this thesis to discussions on return migration}

Chapter 3 highlighted that return is more complex than 'going home', and introduced the concept of multidimensional embeddedness in order to have a holistic approach to the post-return experience of migrants; this concept allowed us to go beyond 'reintegration', as a measure for sustainable return. Chapter 3 analysed the determinants of post-return embeddedness, showing a number of remarkable trends across the six different countries in the study. The strongest findings showed the limited or even negative impact of return assistance, and the significance of the migration cycle experience and in particular the return motivation.

In chapter 5 I therefore focused on the meanings of and motivations for return. I introduced an analytical framework in order to deconstruct return as a complex decision-making process that goes beyond the dichotomies of voluntary and involuntary mobility. I also showed that the narrative is a valuable empirically grounded research methodology for studying the complexity of migration. The chapter, furthermore, highlighted the importance of post-return mobility, which I proposed to centralize in the study of return migration as an indicator of voluntary or involuntary return.

In chapters 6 and 7 I interrogated the expectations of the debate on migration and development that returnees are positively selected, that they benefit from their migration experience and that they form hybrid identities so that they can negotiate change upon their return. Both chapters find that these expectations are too easily formulated and that their accuracy differs according to whether the return is voluntary or involuntary, with transnational mobility being the strongest differentiating factor. The findings therefore highlight the limitations of the applicability of return and development policies.

In chapter 8 I projected these insights on returnees' identifications with the conflict. The chapter highlighted the fact that policy makers' idea that migrants can and should be steered in the nature of their actions raises ethical and practical questions. With regard to the main question of this thesis on the circumstances under which return migrants are willing and able to contribute to development and peacebuilding, I highlighted the importance of human dynamics and transnational mobility. People who had had the right to live part of their lives in security returned with some optimism to the war-torn society. In addition, their transnational mobility made them more autonomous from its structures.

Overall, this thesis showed that the expectations on which migration and development policies are based only apply to a small minority of returnees, who are not the group that is targeted by the policies. With this thesis, I have shown that return migration is a complex process, to which contemporary policy is responding inadequately. Next, I will discuss the policy implications of these conclusions.

\subsubsection{Policy implications: humans as policy instruments?}

Return migrants have come to be seen as a threefold multi-tool whose actions and movements can be controlled to meet host governments' overlapping goals. Policies and budgets on return migration and development are considered as instruments for: 
1. Managing, controlling and regulating the movements of migrants who are economically and politically superfluous by returning them to the country of origin and relieving the burden on the host state;

2. Defending domestic security and welfare by lifting the burden of immigrants from host states while preventing the destabilizing effects of return migration, which may initiate new migration movements or be otherwise harmful for the host society;

3. Shifting the responsibility for development and peace-building to migrants and giving a positive connotation to their return, while controlling and preventing the 'wrong' kind of change, such as revolution, religious-based opposition or political unrest, which may be a threat to (2).

In order to combine these goals into one policy, host governments choose to ignore and blur the understanding of the heterogeneity of returnees, who include failed asylum seekers as well as highly skilled economic migrants. European countries ${ }^{2}$ assign substantial parts, if not the bulk, of their migration and development policies, which are paid out of ODA budgets, to asylum and immigration policies and AVR programmes (ICMPD and ECDPM 2013).

Ineffective return and development policies

This thesis shows why a thorough understanding of the heterogeneity of return migrants is essential for effective policy. While the bulk of the budgets for policies promoting return, development and peace-building go to de facto involuntary returnees, this group is unable to contribute to development in any way. On the contrary, this potential is undermined by restrictive immigration and asylum policies, which damage rather than promote the conditions under which these involuntary returnees could be actors of change. On the other hand, while a proportion of voluntary returnees can potentially contribute to development and peace-building, only small shares of migration and development budgets promote the initiatives of such returnees. This simple but ironic finding is visualized in Figure 9.1, which shows the mismatch between the allocation of development budgets and the development potential of return migrants.

\footnotetext{
2 Notably Belgium, France, the Netherlands and Spain.
} 
Figure 9.1 Development potential of and development budget for return migrants

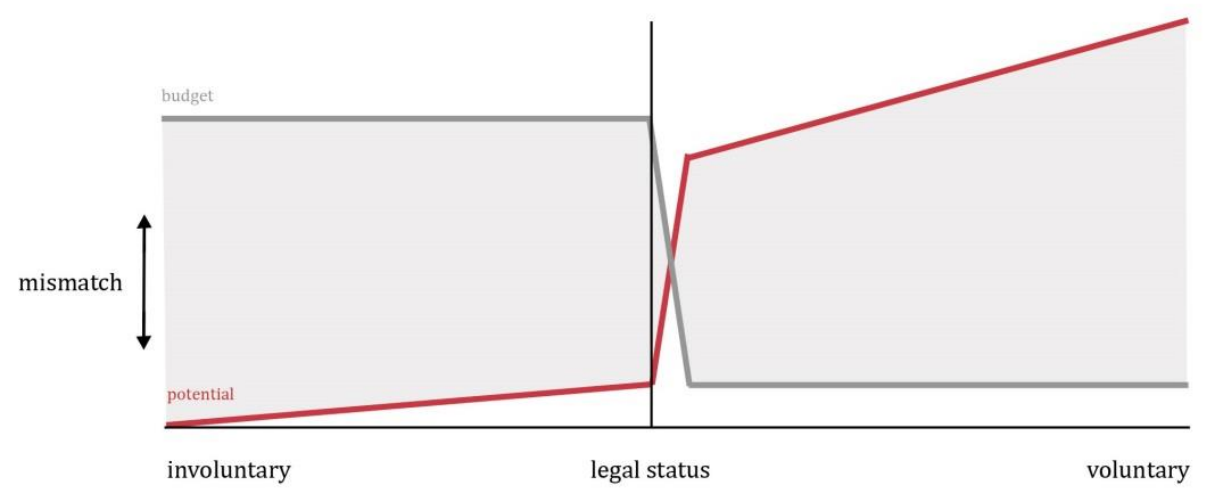

Why is this a problem?

The way migrants are seen as instruments for fulfilling the goals of the host state dehumanizes them, because it fails to see them as purposive actors whose actions are part of dynamic life strategies, ambitions, values and visions (Omata 2013). As part of the values they stand for, governments representing liberal democracies should pay more attention to the individual lives of people, without assuming that they can control migration (Skeldon 2008, Castles, De Haas, and Miller 2014, 318). Rather than being used as an instrument for development, migration should be taken into account as an encompassing aspect of development and conflict. If migration is to contribute to development and security, it should be facilitated rather than contained.

Both policy makers and civil society organizations have however been pragmatic about the mismatch between policy and reality. First, the current policy on return migration and development is intentionally misguided. Several reports have questioned the development potential of return assistance programmes (Van Houte and De Koning 2008, Frouws and Grimmius 2012). However, policy makers have not been responsive to arguments about the limited evidence on return and development and the need for careful wording and definitions regarding the nature of mobility. They are aware that using a vocabulary of 'voluntary return' and 'return migration and development' makes it easier to explain a politically sensitive topic to the public, and that framing the policy in this way enables them to use budgets assigned for development assistance for the return of unwanted migrants. For host country governments, this is a multiple win situation.

Second, non-governmental organizations whose primary goal is the wellbeing of migrants have now been incorporated into the migration and development discourse. ${ }^{3}$ NGOs who became involved in return assistance, as a way to 'do something for those who have to return', now have to comply with the terms of the governments' return policies in order to receive funding, which basically means that they have to produce a target number of returnees. While NGOs oriented towards migrants have an image of

\footnotetext{
3 The governments of Belgium, Italy, the Netherlands and Switzerland, and the European Commission, have outsourced their migration and development policies to international organizations, NGOs or diaspora organizations (ICMPD and ECDPM 2013).
} 
independence in society and among migrants, they are in fact implementing government policy for removing unwanted migrants. The pressure to market their product in what has been called the migration industry (Gammeltoft-Hansen and Sørensen 2012) leads to claims that they contribute to sustainable return or even to development. Such claims may, in turn, be used by governments to legitimize their return policies further.

Expressing these expectations in policy papers, statistics and other communications is, however, not harmless, as it affects our thinking and debating about, and communication with, migrants. Civil servants in charge of convincing migrants to return tend to become frustrated with migrants who are not willing to cooperate with their return. In their optimistic frame, migrants who do not cooperate with 'voluntary return' are unwilling to take responsibility for their own lives (Kalir 2013) and for the development of their country. These expectations, raised by both policy makers and NGOs, strain communication with migrants before return and foster anger and disappointment among returnees who find that the story is not as bright as was presented to them. Their discontent may have a destabilizing effect after their return, which then undermines the goals of migration and development policies.

\section{Undoing the mismatch}

It is therefore both for moral and pragmatic reasons that NGOs and policy makers should acknowledge the real impact of return programmes on individual migrants and development in the country of origin, and to re-evaluate their roles in this process. To undo the mismatch between policy and reality, and in order to formulate adequate policies that not only address the needs and potential of returnees better, but also meet the goals of policy more adequately, I propose two modifications to current policy. First, to avoid further conceptual confusion, de facto involuntary return should no longer be called 'voluntary' but should be redefined in terms that do justice to reality (see chapter 5). Second, since the multi-tool approach, in which an attempt was made to combine multiple goals of different policy fields into one return migration policy, has proved inadequate, it is time to re-evaluate and disentangle the different goals that inform migration and development policies, as displayed in Figure 9.2.

Although the three goals do have some overlap, they imply different needs in relation to return migration. The first goal, of regulating, preventing and reducing migration, implies the need to remove unwanted migrants effectively. Since deportation is both financially and politically costly and ineffective, providing a return incentive to convince migrants to return sometimes works better. Second, the goal of ensuring domestic security and welfare implies the need to prevent any destabilizing effects of return. Both these goals and their needs can be met through financial or inkind return assistance for unwanted migrants. However, the third goal, of promoting development and peace-building in the country of origin, implies the need for an investment in the human capacity of migrants and their continued transnational mobility. Policies promoting the development and peace-building potential of migrants should facilitate both needs (Cassarino 2014). 
Figure 9.2 Disentangling return, development and peace-building goals, needs and policies
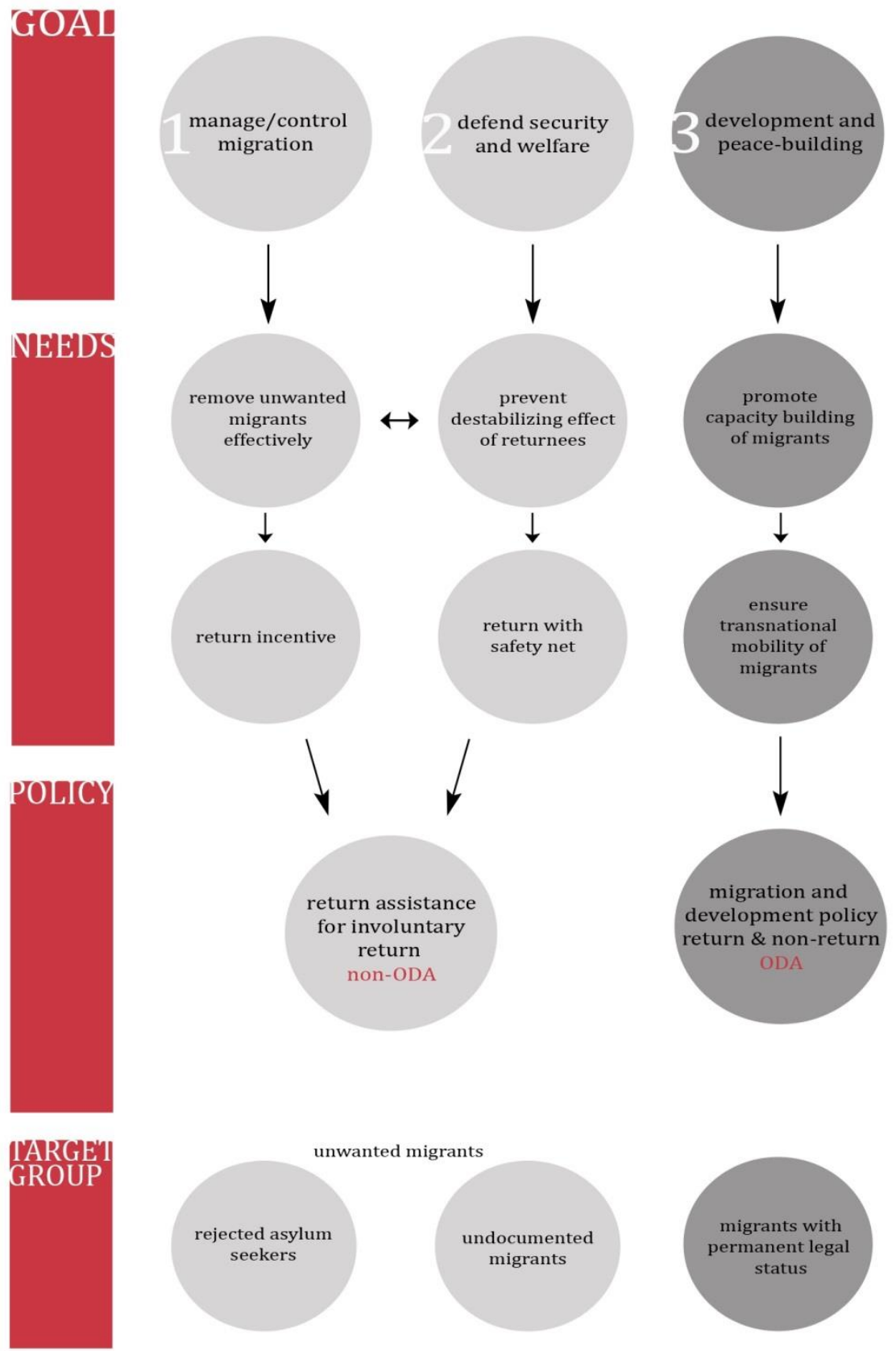
From the discussion above, it becomes clear that these goals are not complementary but rather serve different needs, call for different policies and target different types of migrants. While the first two goals are to put unwanted migrants back in their place, the third goal highlights the need for continued transnational mobility, which does not even require migrants to return. In addition, while the first two goals only meet the needs of the destination countries, the third goal would also favour development and peace-building in the countries of origin of individual migrants, if the migrants were allowed to increase their capacities through rights to employment, education and freedom of movement in the host country.

The different goals and needs therefore imply the use of different budgets: if return is to regulate migration and ensure domestic security and welfare, this is a matter for home affairs and security budgets. It is only if return occurs under the condition of continued transnational mobility and strengthened human capacity that it may meet the goal of promoting development and peace-building, which justifies funding from ODA budgets. Further policy-oriented research is needed to look into how transnational mobility can fit better into current migration and development policies.

This study focused, to an important extent, on the case of Afghanistan. The future of the country and the consequences of this for migration are unclear, and this equally counts for other countries in the region that are currently facing severe crises. What is certain, however, is that migration will always be part of people's survival strategies in times of conflict and crisis. Instead of trying to manage and contain these migration flows, a way forward in the migration and development debate should be how we can facilitate the resilience and determination of people to find a better life. 



\section{References}

Abbasi-Shavazi, Mohammad Jalal, Rasoul Sadeghi, Hossein Mahmoudian, and Gholamreza Jamshidiha. 2012. "Marriage and Family Formation of the Second-Generation Afghans in Iran: Insights from a Qualitative Study." International Migration Review 46 (4):828860. doi: 10.1111/imre.12002.

Ahmed, Sara. 1999. "Home and Away." International Journal of Cultural Studies 2 (3):329-347. doi: 10.1177/136787799900200303.

Al-Ali, Nadje., Richard. Black, and Khalid. Koser. 2001. "Refugees and Transnationalism: The Experience of Bosnians and Eritreans in Europe." Journal of Ethnic and Migration Studies 27 (4):615-634.

Amelina, Anna. 2010. "Searching for an Appropriate Research Strategy on Transnational Migration: The Logic of Multi-Sited Research and the Advantage of the Cultural Interferences Approach." Forum: Qualitative Social Research 11 (1).

Ammassari, Savina. 2004. "From Nation-Building to Entrepreneurship: The Impact of Élite Return Migrants in Côte d'Ivoire and Ghana." Population, Space and Place 10 (2):133154. doi: $10.1002 /$ psp.319.

Appadurai, Arjun. 2010. "How Histories make Geographies." Transcultural Studies 1:4-13. doi: 10.11588/ts.2010.1.6129.

Bagnoli, Anna. 2009. "Beyond the Standard Interview: The Use of Graphic Elicitation and Artsbased Methods." Qualitative Research 9 (5):547-570. doi: $10.1177 / 1468794109343625$.

Bailey, Olga Guedes. 2012. "Migrant African Women: Tales of Agency and Belonging." Ethnic and Racial Studies 35 (5):850-867. doi: 10.1080/01419870.2011.628037.

Bakewell, Oliver. 2008. "Keeping Them in Their Place': The Ambivalent Relationship Between Development and Migration in Africa." Third World Quarterly 29 (7):1341-1358. doi: 10.1080/01436590802386492.

Bakewell, Oliver. 2010. "Some Reflections on Structure and Agency in Migration Theory." Journal of Ethnic and Migration Studies 36 (10):1689-1708. doi: 10.1080/1369183x.2010.489382.

Basch, Linda G., Nina Glick Schiller, and Cristina Szanton Blanc. 1994. Nations Unbound : Transnational Projects, Postcolonial Predicaments, and Deterritorialized NationStates. Langhorne: Gordon and Breach.

Bauman, Zygmunt. 1998. Globalization: The Human Consequences. Cambridge: Polity Press.

Beltman, Daan. 2012. "Voluntary Return Facilities for Aliens Without Residence Permits in Comparative Perspective." In Cross Border Welfare State. Immigration, Social Security and Integration, edited by G.J. Vonk. Antwerpen: Intersentia.

Bhugra, Dinesh, and Matthew A. Becker. 2005. "Migration, Cultural Bereavement and Cultural Identity." World Psychiatry 4 (1):18-24.

Bhugra, Dinesh, Kamaldeep Bhui, Rosemarie Mallett, Manisha Desai, Jayshree Singh, and Julian Leff. 1999. "Cultural Identity and its Measurement: A Questionnaire for Asians." International Review of Psychiatry 11 (2-3):244-249.

Bilge, Sirma. 2010. "Beyond Subordination vs. Resistance: An Intersectional Approach to the Agency of Veiled Muslim Women." Journal of Intercultural Studies 31 (1):9-28. doi: $10.1080 / 07256860903477662$.

Binaisa, Naluwembe. 2011. "Negotiating 'Belonging' to the Ancestral 'Homeland': Ugandan Refugee Descendents 'Return'." Mobilities 6 (4):519-534. doi: 10.1080/17450101.2011.603945.

Black, Richard. 2001. "Return and Reconstruction in Bosnia-Herzegovina: Missing Link, or Mistaken Priority?" SAIS ReviewXXI (2):177-199. 
Black, Richard, and Saskia Gent. 2006. "Sustainable Return in Post-conflict Contexts." International Migration 44 (3):15-38. doi: 10.1111/j.1468-2435.2006.00370.x.

Black, Richard, and Khalid Koser, eds. 1999. The End of the Refugee Cycle?: Refugee Repatriation and Reconstruction. Vol. 4, Forced Migration. New York / Oxford: Berghahn.

Blitz, Brad K., Rosemary Sales, and Lisa Marzano. 2005. "Non-Voluntary Return? The Politics of Return to Afghanistan." Political Studies 53 (1):182-200. doi: 10.1111/j.14679248.2005.00523.x.

Bloch, Alexia. 2011. "Intimate Circuits: Modernity, Migration and Marriage Among Post-Soviet Women in Turkey." Global Networks 11 (4):502-521. doi: 10.1111/j.14710374.2011.00303.x.

Bloch, Alice. 2008. "Zimbabweans in Britain: Transnational Activities and Capabilities." Journal of Ethnic and Migration Studies 34 (2):287-305.

Boyd, Monica, and Elizabeth Grieco. Women and Migration: Incorporating Gender into International Migration Theory 2003 [cited 14 September 2014]. Available from http://www.migrationpolicy.org/article/women-and-migration-incorporatinggender-international-migration-theory.

Braakman, Marije. 2005. Roots and Routes. Questions of Home, Belonging and Return in an Afghan Diaspora. Master's Thesis, Cultural Anthropology and Sociology of nonWestern Societies, Leiden University, Leiden.

Braakman, Marije, and Angela Schlenkhoff. 2007. "Between Two Worlds: Feelings of Belonging While in Exile and the Question of Return." Asien 104 (3):9-22.

Brees, Inge. 2010. "Refugees and Transnationalism on the Thai-Burmese Border." Global Networks 10 (2):282-299. doi: 10.1111/j.1471-0374.2010.00286.x.

Brinkerhoff, Jennifer M. 2011. "Diasporas and Conflict Societies: Conflict Entrepreneurs, Competing Interests or Contributors to Stability and Development?" Conflict, Security \& Development 11 (02):115-143. doi: 10.1080/14678802.2011.572453.

Buitelaar, Marjo. 2006. "'I Am the Ultimate Challenge'. Accounts of Intersectionality in the LifeStory of a Well-Known Daughter of Moroccan Migrant Workers in the Netherlands." European Journal of Women's Studies 13 (3):259-276. doi: $10.1177 / 1350506806065756$.

Carling, Jørgen. 2002. "Migration in the Age of Involuntary Immobility: Theoretical Reflections and Cape Verdean Experiences." Journal of Ethnic and Migration Studies 28 (1):5-42. doi: 10.1080/13691830120103912.

Carling, Jørgen. 2004. "Emigration, Return and Development in Cape Verde: The Impact of Closing Borders." Population, Space and Place 10 (2):113-132. doi: 10.1002/psp.322.

Carling, Jørgen. 2008. "The Human Dynamics of Migrant Transnationalism." Ethnic and Racial Studies 31 (8):1452-1477.

Cassarino, Jean-Pierre. 2004. "Theorising Return Migration: The Conceptual Approach to Return Migrants Revisited." International Journal on Multicultural Societies (IJMS) 6 (2):253279.

Cassarino, Jean-Pierre. 2006. The EU Return Policy: Premises and Implications. Florence: European University Institute / Robert Schuman Centre for Advanced Studies.

Cassarino, Jean-Pierre, ed. 2014. Reintegration and Development. Florence: European University Institute / Robert Schuman Centre for Advanced Studies.

Castles, Stephen. 2003. "Towards a Sociology of Forced Migration and Social Transformation." Sociology 37 (1):13-34. doi: 10.1177/0038038503037001384.

Castles, Stephen. 2005. "Nation and Empire: Hierarchies of Citizenship in the New Global Order." International Politics 42 (2):203-224. doi: 10.1057/palgrave.ip.8800107.

Castles, Stephen. 2007. "Twenty-First-Century Migration as a Challenge to Sociology." Journal of Ethnic and Migration Studies 33 (3):351-371. doi: 10.1080/13691830701234491. 
Castles, Stephen, Hein De Haas, and Mark J Miller. 2014. The Age of Migration: International Population Movements in the Modern World. 5th ed. Basingstoke / New York: Palgrave Macmillan.

Castles, Stephen, and Mark J Miller. 2009. The Age of Migration: International Population Movements in the Modern World. 4th ed. Basingstoke / New York: Palgrave Macmillan.

Cerase, Francesco P. 1974. "Expectations and Reality: A Case Study of Return Migration from the United States to Southern Italy." International Migration Review 8 (2):245-262.

Chambers, Robert, and Gordon Conway. 1992. Sustainable Rural Livelihoods: Practical Concepts for the 21st Century. Brighton: Institute of Development Studies.

Chan, Yuk Wah, and Thi Le Thu Tran. 2011. "Recycling Migration and Changing Nationalisms: The Vietnamese Return Diaspora and Reconstruction of Vietnamese Nationhood." Journal of Ethnic and Migration Studies 37 (7):1101-1117. doi: 10.1080/1369183x.2011.572486.

Chanfrault-Duchet, Marie-Francoise. 1991. "Narrative Structures, Social Models, and Symbolic Representation in the Life Story." In Women's Words: The Feminist Practice of Oral History, edited by S. Berger Gluck and D. Patai, 77-92. London / New York: Routledge.

Charsley, Katharine, and Anika Liversage. 2013. "Transforming Polygamy: Migration, Transnationalism and Multiple Marriages among Muslim Minorities." Global Networks 13 (1):60-78. doi: 10.1111/j.1471-0374.2012.00369.x.

Charsley, Katharine, and Alison Shaw. 2006. "South Asian Transnational Marriages in Comparative Perspective." Global Networks 6 (4):331-344. doi: 10.1111/j.14710374.2006.00147.x.

Chimni, B. S. 2000. "Globalization, Humanitarianism and the Erosion of Refugee Protection." Journal of Refugee Studies 13 (3):243-263. doi: 10.1093/jrs/13.3.243.

Chimni, B. S. 2002. "Refugees, Return and Reconstruction of Post-Conflict Societies: a Critical Perspective." International Peacekeeping 9 (2):163-180.

Chimni, Bupinder S. 1999. From Resettlement to Involuntary Repatriation: Towards a Critical History of Durable Solutions to Refugee Problems. In New Issues in Refugee Research. Geneva: UNCHR.

Christou, Anastasia. 2006. "Deciphering Diaspora - Translating Transnationalism: Family Dynamics, Identity Constructions and the Legacy of 'Home' in Second-Generation Greek-American Return Migration." Ethnic and Racial Studies 29 (6):1040-1056. doi: 10.1080/01419870600960297.

Cochrane, Feargal. 2007. "Civil Society beyond the State: The Impact of Diaspora Communities on Peace Building." Global Media Journal: Mediterranean Edition 2 (2):19-27.

Collier, Paul, and Anke Hoeffler. 1998. "On Economic Causes of Civil War." Oxford Economic Papers no. 50 (4):563-573.

Collins, Joseph J. 2011. Understanding War in Afghanistan. Washington: National Defence University Press.

Conrad, Diane. 2004. "Exploring Risky Youth Experiences: Popular Theatre as a Participatory, Performative Research Method." International Journal of Qualitative Methods 3 (1):12-25.

Cramer, Christopher, and Jonathan Goodhand. 2002. "Try Again, Fail Again, Fail Better? War, the State, and the 'Post-Conflict' Challenge in Afghanistan." Development and Change 33 (5):885-909. doi: 10.1111/1467-7660.t01-1-00253.

D’onofrio, Lisa. 2004. Welcome Home? Minority Return in South-Eastern Republika Srspka. In Sussex Migration Working Paper. Brighton: University of Sussex.

Davids, Tine. 2011. "The Micro Dynamics of Agency: Repetition and Subversion in a Mexican Right-Wing Female Politician's Life Story." European Journal of Women's Studies 18 (2):155-168. doi: 10.1177/1350506810395437.

Davis, K., H. J. Kuipers, and H. Lutz. 1995. "Identiteit en Biografie: Inleiding tot het Themagedeelte." Comenius (Themanummer Identiteit en Biografie) 3:243-250. 
De Bree, June. 2008. Return Migration to Afghanistan. Nijmegen / Amsterdam: CIDIN / AMIDSt.

De Bree, June, Tine Davids, and Hein De Haas. 2010. "Post-return Experiences and Transnational Belonging of Return Migrants: a Dutch-Moroccan Case Study." Global Networks 10 (4):489-509. doi: 10.1111/j.1471-0374.2010.00299.x.

De Haan, Leo, and Annelies Zoomers. 2003. "Development Geography at the Crossroads of Livelihood and Globalisation." Tijdschrift voor Economische en Sociale Geografie 94 (3):350-362.

De Haas, Hein. 2005. "International Migration, Remittances and Development: Myths and Facts." Third World Quarterly 26 (8):1269-1284.

De Haas, Hein. 2006. Engaging Diasporas: How Governments and Development Agencies Can support Diaspora Involvement in the Development of Origin Countries. Oxford: International Migration Institute.

De Haas, Hein. 2010. "Migration and Development: A Theoretical Perspective." International Migration Review 44 (1):227-264. doi: 10.1111/j.1747-7379.2009.00804.x.

Dekker, Bram, and Melissa Siegel. 2013. Transnationalism and Integration: Complements or Substitutes? In UNU-MERIT Working Papers. Maastricht: Maastricht Graduate School of Governance.

Dennis, Barbara. 2009. "Acting Up: Theater of the Oppressed as Critical Ethnography." International Journal of Qualitative Methods 8 (2):65-96.

Dimitrijevic, M., Z. Todorovic, and N. Grkovic. 2004. The Experience of Decision-Making and Repatriation Process. Return of Serbian Refugees to Croatia. Belgrade Danish Refugee Council.

Dolan, Chris. 1999. "Repatriation from South Africa to Mozambique-Undermining Durable Solutions?'." In The End of the Refugee Cycle? Refugee Repatriation and Reconstruction, edited by Richard Black and Khalid Koser, 85-108. New York / Oxford: Berghahn.

Duffield, Mark. 2006. "Racism, Migration and Development: the Foundations of Planetary Order." Progress in Development Studies 6 (1):68-79. doi: 10.1191/1464993406ps128oa.

Dupree, Louis. 1975. "Settlement and Migration Patterns in Afghanistan: A Tentative Statement." Modern Asian Studies 9 (03):397-413.

Dwyer, Claire. 2000. "Negotiating Diasporic Identities: Young British South Asian Muslim Women." Women's Studies International Forum 23 (4):475-486.

Easthope, Hazel. 2009. "Fixed Identities in a Mobile World? The Relationship Between Mobility, Place and Identity." Identities 16 (1):61-82. doi: 10.1080/10702890802605810.

Eastmond, Marita. 2006. "Transnational Returns and Reconstruction in Post-war Bosnia and Herzegovina." International Migration 44 (3):141-166. doi: 10.1111/j.14682435.2006.00375.x.

Eastmond, Marita. 2007. "Stories as Lived Experience: Narratives in Forced Migration Research." Journal of Refugee Studies 20 (2):248-264. doi: 10.1093/jrs/fem007.

EC. 2013. Maximizing the Development Impact of Migration. The EU Contribution for the UN High-Level Dialogue and Next Steps Towards Broadening the Development-Migration Nexus. Communication From the Commission to the European Parliament, the Council, the European Economic and Social Committee and the Committee of the Regions. Brussels: European Commission.

Emirbayer, Mustafa, and Ann Mische. 1998. "What Is Agency?" American Journal of Sociology 103 (4):962-1023. doi: 10.1086/231294.

Erdal, Marta Bivand. 2012. "'A Place to Stay in Pakistan': Why Migrants Build Houses in their Country of Origin." Population, Space and Place 18 (5):629-641. doi: 10.1002/psp.1694.

Erdal, Marta Bivand, and Ceri Oeppen. 2013. "Migrant Balancing Acts: Understanding the Interactions Between Integration and Transnationalism." Journal of Ethnic and Migration Studies 39 (6):867-884. doi: 10.1080/1369183X.2013.765647. 
Eriksen, Thomas Hylland. 1995. Small Places, Large Issues, Anthropology, Culture and Society. London / New York: Pluto.

Ewing, Katherine P. 1990. "The Illusion of Wholeness: Culture, Self and the Experience of Inconsistency." Ethos 18 (3):251-278. doi: 10.1525/eth.1990.18.3.02a00020.

Fairclough, Norman. 1992. "Discourse and Text: Linguistic and Intertextual Analysis within Discourse Analysis." Discourse \& Society $3 \quad$ (2):193-217. doi: 10.1177/0957926592003002004.

Faist, Thomas. 2004. "The Transnational Turn in Migration Research: Perspectives for the Study of Politics and Polity." In Transnational Spaces: Disciplinary Perpectives, edited by Maja Povrzanovic Frykman, 11-45. Malmö: International Migration and Ethnic Relations, Malmö University.

Faist, Thomas. 2008. "Migrants as Transnational Development Agents: An Inquiry Into the Newest Round of the Migration-Development Nexus." Population, Space and Place 14 (1):21-42. doi: $10.1002 /$ psp.471.

Findlay, Allan M., and F. L. N. Li. 1997. "An Auto-Biographical Approach to Understanding Migration: The Case of Hong Kong Emigrants." Area 29 (1):34-44. doi: 10.1111/j.1475-4762.1997.tb00005.x.

Frouws, Bram, and Ton Grimmius. 2012. Migratie en Ontwikkeling. Beleidsevaluatie van het Nederlandse Migratie- en Ontwikkelingsbeleid sinds 2008. Eindrapport Research voor Beleid / Maastricht University.

Gammeltoft-Hansen, Thomas, and Ninna Nyberg Sørensen. 2012. "Introduction." In The Migration Industry and the Commercialization of International Migration, edited by Thomas Gammeltoft-Hansen and Ninna Nyberg Sørensen. Abingdon / New York: Routledge.

Gardner, Katy, and Ralph Grillo. 2002. "Transnational Households and Ritual: An Overview." Global Networks 2 (3):179-190. doi: 10.1111/1471-0374.00035.

Gauntlett, David. 2007. Creative Explorations: New approaches to Identities and Audiences. Abingdon / New York: Routledge.

GCIM. 2005. Migration in an Interconnected World: New Directions for Action. Geneva: Global Commission on International Migration.

Gerholm, Lena. 2003. "Overcoming Temptation: On Masculinity and Sexuality Among Muslims in Stockholm." Global Networks 3 (3):401-416. doi: 10.1111/1471-0374.00069.

Ghanem, Tania. 2003. When Forced Migrants Return 'Home': The Psychological Difficulties Returnees Encounter in the Reintegration Process. In RSC Working Paper. Oxford: University of Oxford.

Ghorashi, Halleh. 2001. Ways to Survive, Battles to Win: Iranian Women Exiles in the Netherlands and the US, Katholieke Universiteit Nijmegen, Nijmegen.

Ghorashi, Halleh. 2003. "Multiple Identities Between Continuity and Change. The Narratives of Iranian Women in Exile." Focaal-European Journal of Anthropology (42):63-75.

Gibbs, Graham R. 2007. Analyzing Qualitative Data. Vol. 6, The Sage Qualitative Research Kit. Los Angeles: Sage.

Giddens, Anthony. 1991. Modernity and Self-Identity: Self and Society in the Late Modern Age. Cambridge: Polity Press.

Gmelch, George. 1980. "Return Migration." Annual Review of Anthropology 9:135-159. doi: $10.2307 / 2155732$.

Gobo, Giampietro. 2008. Doing Ethnography, Introducing Qualitative Methods. London / Thousand Oaks: SAGE.

Granovetter, Mark. 1985. "Economic Action and Social Structure: The Problem of Embeddedness." American Journal of Sociology 91 (3):481-510.

Guarnizo, Luis Eduardo. 1997. "The Emergence of a Transnational Social Formation and The Mirage of Return Migration Among Dominican Transmigrants." Identities 4 (2):281322. doi: 10.1080/1070289x.1997.9962591. 
Guarnizo, Luis Eduardo, Alejandro Portes, and William Haller. 2003. "Assimilation and Transnationalism: Determinants of Transnational Political Action among Contemporary Migrants." American Journal of Sociology 108 (6):1211-1248.

Hall, Jonathan, and Roland Kostić. 2009. Does Integration Encourage Reconciliatory Attitudes among Diasporas? In Global Migration and Transnational Politics Working Paper. Fairfax: Center for Global Studies, George Mason University.

Hammond, Laura. 1999. "Examining the Discourse of Repatriation: Towards a More Proactive Theory of Return Migration." In The End of the Refugee Cycle? Refugee Repatriation and Reconstruction, edited by Richard Black and Khalid Koser, 227-244. New York / Oxford: Berghahn.

Hammond, Laura. 2004. "The Making of a Good Citizen in an Ethiopian Returnee Settlement." In Coming Home? Refugees, Migrants, and Those Who Stayed Behind, edited by L.D. Long and E. Oxfeld. Philadelphia: University of Pennsylvania.

Hess, Martin. 2004. "'Spatial' Relationships? Towards a Reconceptualization of Embeddedness." Progress in Human Geography 28 (2):165-186.

Hitlin, Steven, and Glen H. Elder. 2007. "Time, Self, and the Curiously Abstract Concept of Agency." Sociological Theory 25 (2):170-191. doi: 10.1111/j.1467-9558.2007.00303.x.

Horst, Cindy. 2008. "A Monopoly on Assistance: International Aid to Refugee Camps and the Neglected Role of the Somali Diaspora." Afrika Spectrum 43 (1):121-131.

Horst, Heather A. 2007. "You Can't Be Two Places At Once': Rethinking Transnationalism Through Jamaican Return Migration." Identities 14 (1-2):63-83. doi: $10.1080 / 10702890601102522$.

Hyndman, Jennifer. 2012. "The Geopolitics of Migration and Mobility." Geopolitics 17 (2):243255. doi: 10.1080/14650045.2011.569321.

ICMPD and ECDPM. 2013. Migration and Development Policies and Practices. A mapping study of eleven European countries and the European Commission. Vienna / Maastricht: ICMPD / ECDPM.

IOM. http://Www.iom.int/cms/afghanistan. IOM [cited 11 September 2014].

IOM. 2004. International Migration Law: Glossary on Migration. Geneva: IOM.

IRIN. Migration: Afghan Asylum-Seekers Hit by Tighter Immigration Rules. IRIN 2011 [cited 27 March 2014]. Available from http://www.irinnews.org/Report/92329/MIGRATIONAfghan-asylum-seekers-hit-by-tighter-immigration-rules.

Ismailbekova, Aksana. 2013. "Coping Strategies: Public Avoidance, Migration, and Marriage in the Aftermath of the Osh Conflict, Fergana Valley." Nationalities Papers no. 41 (1):109127. doi: 10.1080/00905992.2012.748736.

Jackson, Michael. 2002. The Politics of Storytelling: Violence, Transgression, and Intersubjectivity. Copenhagen: Museum Tusculanum Press.

Jacobsen, Karen, and Loren B. Landau. 2003. "The Dual Imperative in Refugee Research: Some Methodological and Ethical Considerations in Social Science Research on Forced Migration." Disasters 27 (3):185-206.

Jain, Sonali. 2012. "For Love and Money: Second-Generation Indian-Americans 'Return' to India." Ethnic and Racial Studies 36 (5):896-914. doi: 10.1080/01419870.2011.641576.

Jazayery, Leila. 2002. "The Migration-Development Nexus: Afghanistan Case Study." International Migration 40 (5):231-254. doi: 10.1111/1468-2435.00218.

Jones, Richard C. 2011. "The Local Economic Imprint of Return Migrants in Bolivia." Population, Space and Place 17 (5):435-453. doi: 10.1002/psp.626.

Kalir, Barak. 2013. Paper read at Migration, Stockholm and Beyond: The Follow Up of the 2009 Stockholm Programme on Migration Governance; The Need for Further Steps, December 9, at The Hague.

Kaptani, Erene, and Nira Yuval-Davis. 2008. "Participatory Theatre as a Research Methodology: Identity, Performance and Social Action Among Refugees." Sociological Research Online 13 (5):2. doi: doi:10.5153/sro.1789. 
Kent, Gregory. 2006. "Organised Diaspora Networks and Homeland Peacebuilding: the Bosnian World Diaspora Network as a Potential Development Actor." Conflict, Security \& Development 6 (3):449-469. doi: 10.1080/14678800600933639.

King, Russell. 1978. "Return Migration: A Neglected Aspect of Population Geography." Area 10 (3):175-182. doi: 10.2307/20001343.

King, Russell. 2000. "Generalizations From the History of Return Migration." In Return migration: Journey of Hope or Despair, edited by B. Ghosh, 7-55. Geneva: IOM / UNHCR.

King, Russell. 2012. "Geography and Migration Studies: Retrospect and Prospect." Population, Space and Place 18 (2):134-153. doi: 10.1002/psp.685.

King, Russell, and Anastasia Christou. 2010. "Cultural Geographies of Counter-Diasporic Migration: Perspectives from the Study of Second-Generation 'Returnees' to Greece." Population, Space and Place 16 (2):103-119. doi: 10.1002/psp.543.

King, Russell, and Anastasia Christou. 2011. "Of Counter-Diaspora and Reverse Transnationalism: Return Mobilities to and from the Ancestral Homeland." Mobilities 6 (4):451-466. doi: 10.1080/17450101.2011.603941.

King, Russell, Anastasia Christou, and Janine Teerling. 2011. "We took a Bath with the Chickens': Memories of Childhood Visits to the Homeland by Second-Generation Greek and Greek Cypriot 'Returnees'." Global Networks 11 (1):1-23. doi: 10.1111/j.14710374.2010.00304.x.

Kloosterman, Robert C, Joanne Van Der Leun, and Jan Rath. 1999. "Mixed Embeddedness: (In) Formal Economic Activities and Immigrant Businesses in the Netherlands." International Journal of Urban and Regional Research 23 (2):252-266.

Kloosterman, Robert C. 2010. "Matching Opportunities with Resources: A Framework for Analysing (Migrant) Entrepreneurship from a Mixed Embeddedness Perspective." Entrepreneurship \& Regional Development 22 (1):25-45. doi: 10.1080/08985620903220488.

König, Jutta. 2009. "Moving Experience: Dialogues between Personal Cultural Positions." Culture \& Psychology 15 (1):97-119. doi: 10.1177/1354067x08099617.

Koser, Khalid. 2014. Transition, Crisis and Mobility in Afghanistan: Rhetoric and Reality. Geneva: IOM.

Koser, Khalid, and Richard Black. 1999. "The End of the Refugee Cycle?" In The End of the Refugee Cylce? Refugee Repatriation and Reconstruction, edited by Richard Black and Khalid Koser, 2-17. New York / Oxford: Berghahn Books.

Koser, Khalid, and Susanne Schmeidl. 2009. Displacement, Human Development, and Security in Afghanistan. Paper read at Displacement in the Muslim World: A Focus on Afghanistan and Iraq, at Washington.

Koser, Khalid, and Nicholas Van Hear. 2003. Asylum Migration and Implications for Countries of Origin. WIDER discussion paper 2003/20, http://www.unu.edu/hq/library/Collection/PDF_files/WIDER/WIDERdp2003.20.pdf.

Kronenfeld, Daniel A. 2008. "Afghan Refugees in Pakistan: Not All Refugees, Not Always in Pakistan, Not Necessarily Afghan?" Journal of Refugee Studies 21 (1):43-63. doi: $10.1093 /$ jrs $/$ fem048.

Levitt, Peggy, Kristen Lucken, and Melissa Barnett. 2011. "Beyond Home and Return: Negotiating Religious Identity across Time and Space through the Prism of the American Experience." Mobilities 6 (4):467-482. doi: 10.1080/17450101.2011.603942.

Levitt, Peggy, and Nina Glick Schiller. 2004. "Conceptualizing Simultaneity: A Transnational Social Field Perspective on Society." International Migration Review 38 (3):10021039. doi: 10.1111/j.1747-7379.2004.tb00227.x.

Levitt, Peggy, and Ninna Nyberg Sørensen. 2004. The Transnational Turn in Migration Studies. In Global Migration Perspectives. Geneva: Global Commission on International Migration. 
Ley, David. 2004. "Transnational Spaces and Everyday Lives." Transactions of the Institute of British Geographers 29 (2):151-164. doi: 10.1111/j.0020-2754.2004.00122.x.

Li, F. L. N., A. J. Jowett, Allan M. Findlay, and Ronald Skeldon. 1995. "Discourse on Migration and Ethnic Identity: Interviews with Professionals in Hong Kong." Transactions of the Institute of British Geographers 20 (3):342-356.

Lindley, Anna. 2007. The Early Morning Phonecall: Remittances from a Refugee Diaspora Perspective. Oxford: Centre on Migration, Policy and Society.

Long, Lynellyn D, and Ellen Oxfeld. 2004a. "Introduction." In Coming Home? Refugees, Migrants, and Those Who Stayed Behind, edited by Lynellyn D Long and Ellen Oxfeld, 1-15. Philadelphia: University of Pennsylvania.

Long, Lynellyn D., and Ellen Oxfeld, eds. 2004b. Coming Home? Refugees, Migrants, and Those Who Stayed Behind. Philadelphia: University of Pennsylvania.

Lubkemann, Stephen C. 2008. "Involuntary Immobility: On a Theoretical Invisibility in Forced Migration Studies." Journal of Refugee Studies 21 (4):454-475. doi: $10.1093 / \mathrm{jrs} / \mathrm{fen} 043$.

Lutz, Helma. 1998. "The Legacy of Migration: Immigrant Mothers and Daughters and the Process of Intergenerational Transmission." In Caribbean Migration. Globalised Identities, edited by Mary Chamberlain, 96-110. London: Routledge.

Lyons, Terrence. 2004. Engaging Diasporas to Promote Conflict Resolution: Transforming Hawks into Doves. George Mason University.

Mac Ginty, Roger. 2010. "Warlords and the Liberal Peace: State-Building in Afghanistan." Conflict, Security \& Development $10 \quad$ (4):577-598. doi: $10.1080 / 14678802.2010 .500548$.

Mai, Nicola, and Russell King. 2009. "Love, Sexuality and Migration: Mapping the Issue(s)." Mobilities 4 (3):295-307. doi: 10.1080/17450100903195318.

Malkki, Liisa. 1992. "National Geographic: The Rooting of Peoples and the Territorialization of National Identity Among Scholars and Refugees." Cultural Anthropology 7 (1):24-44. doi: 10.1525/can.1992.7.1.02a00030.

Marsden, Peter. 1999. "Repatriation and Reconstruction: the Case of Afghanistan." In The End of the Refugee Cycle? Refugee Repatriation and Reconstruction, edited by Richard Black and Khalid Koser, 56-68. New York / Oxford: Berghahn Books.

Massey, Doreen. 1993. "Power-Geometry and a Progressive Sense of Place." In Mapping the Futures: Local Cultures, Global Change, edited by John Bird, Barry Curtis, Tim Putnam and Lisa Tickner, 59-69. London / New York: Routledge.

Massey, Douglas S., Joaquin Arango, Graeme Hugo, Ali Kouaouci, Adela Pellegrino, and J. Edward Taylor. 1993. "Theories of International Migration: A Review and Appraisal." Population and Development Review 19 (3):431-466. doi: 10.2307/2938462.

Mazzucato, Valentina. 2008. "The Double Engagement: Transnationalism and Integration. Ghanaian Migrants' Lives Between Ghana and The Netherlands." Journal of Ethnic and Migration Studies 34 (2):199-216. doi: 10.1080/13691830701823871.

Mazzucato, Valentina. 2011. "Reverse Remittances in the Migration-Development Nexus: TwoWay Flows Between Ghana and the Netherlands." Population, Space and Place 17 (5):454-468. doi: 10.1002/psp.646.

Mazzucato, Valentina, and Djamila Schans. 2011. "Transnational Families and the Well-Being of Children: Conceptual and Methodological Challenges." Journal of Marriage and Family 73 (4):704-712. doi: 10.1111/j.1741-3737.2011.00840.x.

Meeus, Bruno. 2012. "How to 'Catch' Floating Populations? Research and the Fixing of Migration in Space and Time." Ethnic and Racial Studies 35 (10):1775-1793. doi: 10.1080/01419870.2012.659272.

Mohamoud, Abdullah A. 2006. African Diaspora and Post-Conflict Reconstruction in Africa. In DIIS Brief. Copenhagen: Danish Institute for International Studies. 
Mommers, Christian, and Evi Velthuis. 2010. Leaving The Netherlands. Twenty Years of Voluntary Return Policy in the Netherlands (1989-2009). The Hague: International Organization for Migration.

Monsutti, Alessandro. 2008. "Afghan Migratory Strategies and the Three Solutions to the Refugee Problem." Refugee Survey Quarterly 27 (1):58-73. doi: 10.1093/rsq/hdn007.

Nagel, Caroline R., and Lynn A. Staeheli. 2004. "Citizenship, Identity and Transnational Migration: Arab Immigrants to the United States." Space and Polity 8 (1):3-23. doi: $10.1080 / 13562570410001678860$.

Nijhof, Gerhard. 2000. Levensverhalen: De Methode van Autobiografisch Onderzoek in de Sociologie. Amsterdam: Boom.

Noll, Gregor. 1999. "Rejected Asylum Seekers: The Problem of Return." International Migration 37 (1):267-288.

O'Neill, Maggie, Sara Giddens, Patricia Breatnach, Carl Bagley, Darren Bourne, and Tony Judge. 2002. "Renewed Methodologies for Social Research: Ethno-Mimesis as Performative Praxis." The Sociological Review 50 (1):69-88. doi: 10.1111/1467-954x.00355.

Oeppen, Ceri. 2009. A Stranger at Home: Integration, Transnationalism and the Afghan Elite, University of Sussex, Sussex.

Oeppen, Ceri. 2012. "A Stranger at 'Home': 'Interactions Between Transnational Return Visits and Integration for Afghan-American Professionals." Global Networks 13 (2):261-278. doi: 10.1111/glob.12008.

Omata, Naohiko. 2013. "The Complexity of Refugees' Return Decision-Making in a Protracted Exile: Beyond the Home-Coming Model and Durable Solutions." Journal of Ethnic and Migration Studies 39 (8):1281-1297. doi: 10.1080/1369183X.2013.778149.

Özerdem, Alpaslan, and Abdul Hai Sofizada. 2006. "Sustainable Reintegration to Returning Refugees in Post-Taliban Afghanistan: Land-Related Challenges." Conflict, Security \& Development 6 (1):75-100. doi: 10.1080/14678800600590678.

Pain, Rachel, and Peter Francis. 2003. "Reflections on Participatory Research." Area 35 (1):4654. doi: 10.1111/1475-4762.00109.

Pedersen, Marianne Holm. 2003. Between Homes: Post-war Return, Emplacement and the Negotiation of Belonging in Lebanon. In New Issues in Refugee Research. Geneva: UNHCR.

Phillips, Nelson, and Cynthia Hardy. 2002. Discourse Analysis: Investigating Processes of Social Construction. Vol. 50, Sage University Papers Series on Qualitative Research Methods. Thousand Oaks, CA.: Sage.

Piotrowski, Martin, and Yuying Tong. 2013. "Straddling Two Geographic Regions: The Impact of Place of Origin and Destination on Return Migration Intentions in China." Population, Space and Place 19 (3):329-349. doi: 10.1002/psp.1715.

Portes, Alejandro. 1999. "Conclusion: Towards a New World - the Origins and Effects of Transnational Activities." Ethnic and Racial Studies 22 (2):463-477.

Portes, Alejandro, and Julia Sensenbrenner. 1993. "Embeddedness and Immigration: Notes on the Social Determinants of Economic Action." American Journal of Sociology 98 (6):1320-1350.

Potter, Robert B. 2005. "Young, Gifted and Back': Second-generation Transnational Return Migrants to the Caribbean." Progress in Development Studies 5 (3):213-236. doi: 10.1191/1464993405ps114oa.

Raghuram, Parvati. 2009. "Which Migration, What Development? Unsettling the Edifice of Migration and Development." Population, Space and Place 15 (2):103-117. doi: $10.1002 /$ psp.536.

Rostami-Povey, Elaheh. 2007. "Afghan Refugees in Iran, Pakistan, the UK, and the US and Life after Return: A Comparative Gender Analysis." Iranian Studies 40 (2):241-261. doi: $10.1080 / 00210860701269576$. 
Ruben, Ruerd, Marieke Van Houte, and Tine Davids. 2009. "What Determines the Embeddedness of Forced-Return Migrants? Rethinking the Role of Pre- and PostReturn Assistance." International Migration Review 43 (4):908-937.

Rubin, Barnett R. 2002. The Fragmentation of Afghanistan. State Formation and Collapse in the International System. 2nd ed. New Haven / London: Yale University Press.

Rubin, Barnett R. 2006. "Peace Building and State-Building in Afghanistan: Constructing Sovereignty for Whose Security?" Third World Quarterly 27 (1):175-185. doi: $10.1080 / 01436590500370038$.

Sadat, Mir Hekmatullah. 2008. "Hyphenating Afghaniyat (Afghan-ness) in the Afghan Diaspora." Journal of Muslim Minority Affairs 28 (3):329-342. doi: $10.1080 / 13602000802547898$.

Salih, Ruba. 2002. "Reformulating Tradition and Modernity: Moroccan Migrant Women and the Transnational Division of Ritual Space." Global Networks 2 (3):219-231. doi: 10.1111/1471-0374.00038.

Schuster, Liza. 2011. "Turning Refugees Into 'Illegal Migrants': Afghan Asylum Seekers in Europe." Ethnic and Racial Studies 34 (8):1392-1407. doi: 10.1080/01419870.2010.535550.

Schuster, Liza, and Nassim Majidi. 2013. "What Happens Post-deportation? The Experience of Deported Afghans." Migration Studies 1 (2):221-240. doi: $10.1093 /$ migration/mns011.

Sewell, William H., Jr. 1992. "A Theory of Structure: Duality, Agency, and Transformation." American Journal of Sociology 98 (1):1-29. doi: 10.2307/2781191.

Sherrell, Kathy, and Jennifer Hyndman. 2006. "Global Minds, Local Bodies: Kosovar Transnational Connections Beyond British Columbia." Refuge: Canada's Journal on Refugees 23 (1):16-26.

Shindo, Reiko. 2012. "The Hidden Effect of Diaspora Return to Post-Conflict Countries: The Case of Policy and Temporary Return to Rwanda." Third World Quarterly 33 (9):16851702. doi: 10.1080/01436597.2012.721232.

Sinatti, Giulia. 2011. "'Mobile Transmigrants' or 'Unsettled Returnees'? Myth of Return and Permanent Resettlement Among Senegalese Migrants." Population, Space and Place 17 (2):153-166. doi: 10.1002/psp.608.

Singh, Deepali Gaur. 2010. Afghan Women in the Diaspora: Surviving Identity and Alienation. In NTS-Asia Research Paper. Singapore: RSIS Centre for Non-Traditional Security.

Skeldon, Ronald. 2008. "International Migration as a Tool in Development Policy: A Passing Phase?" Population and Development Review 34 (1):1-18. doi: 10.1111/j.17284457.2008.00203.x.

Smith, Deborah. 2009. Decisions, Desires and Diversity: Marriage Practices in Afghanistan. In Issues Paper Series. Kabul: The Afghanistan Research and Evaluation Unit (AREU).

Smith, Michael Peter, and Luis Eduardo Guarnizo, eds. 1998. Transnationalism From Below. New Brunswick, NJ: Transaction Publishers.

Snel, Erik, Godfried Engbersen, and Arjen Leerkes. 2006. "Transnational Involvement and Social Integration." Global Networks 6 (3):285-308.

Sørensen, Ninna Nyberg, Nicholas Van Hear, and Poul Engberg-Pedersen. 2002. "The MigrationDevelopment Nexus: Evidence and Policy Options." International Migration 40 (5):4973.

Stein, Barry N., and Frederick C. Cuny. 1994. "Refugee Repatriation During Conflict: Protection and Post-Return Assistance." Development in Practice 4 (3):173-187. doi: $10.1080 / 096145249100077811$.

Stigter, Elca. 2006. "Afghan Migratory Strategies - An Assesment of Repatriation and Sustainable Return in Response to the Convention Plus." Refugee Survey Quarterly 25 (2):109122. doi: $10.1093 / \mathrm{rsq} / \mathrm{hdi} 0129$. 
Strand, Arne, Arghawan Akbari, Torunn Wimpelmann Chaudhary, Kristian Berg Harpviken, Akbar Sarwari, and Astri Suhrke. 2008. Return with Dignity, Return to What? Review of the Voluntary Return Programme to Afghanistan. In CMI Report. Bergen: Chr. Michelsen Institute.

Suhrke, Astri. 2007. "Reconstruction as Modernisation: the 'Post-conflict' Project in Afghanistan." Third World Quarterly 28 (7):1291-1308. doi: 10.1080/01436590701547053.

Timotijevic, Lada, and Glynis M. Breakwell. 2000. "Migration and Threat to Identity." Journal of Community \& Applied Social Psychology 10 (5):355-372.

Tsuda, Takeyuki. 1999. "The Permanence of 'Temporary' Migration: The 'Structural Embeddedness' of Japanese-Brazilian Immigrant Workers in Japan." The Journal of Asian Studies 58 (3):687-722.

Tsuda, Takeyuki. 2004. Migration and Alienation: Japanese-Brazilian Return Migrants and the Search for Homeland Abroad. Chicago: University of Chicago.

Turton, David, and Peter Marsden. 2002. Taking Refugees for a Ride? The Politics of Refugee Return to Afghanistan. In Issues Paper Series. Islamabad: The Afghanistan Research and Evaluation Unit (AREU).

UNHCR. 1997. The State of The World's Refugees 1997: A Humanitarian Agenda. Geneva: UNHCR.

UNHCR. 2009. UNHCR Elegibility Guidelines for Assessing the International Protection Needs of Asylum-Seekers from Afghanistan.

UNHCR. Afghanistan Fact Sheet 2013a [cited 14 September 2014]. Available from http://www.unhcr.org/50002021b.html.

UNHCR. 2013b. Statistical Yearbook 2012. Geneva: UNHCR.

UNHCR. 2013c. UNHCR Eligibility Guidelines for Assessing the International Protection Needs of Asylum-Seekers from Afghanistan. Geneva: UNHCR.

Van Bijlert, Martine. Candidate Positioning after the Preliminary Results. Afghan Analysts Network 2014. Available from https://www.afghanistan-analysts.org/elections-201438-candidates-repositioning-after-the-preliminary-results/.

Van Hear, Nicholas. 2003. From Durable Solutions to Transnational Relations: Home and Exile Among Refugee Diasporas In New Issues in Refugee Research. Geneva: UNHCR.

Van Houte, Marieke. Forthcoming 2014. "Returnees for Change? Afghan Return Migrants' Identification with the Conflict and their Potential to be Agents of Change." Conflict, Security \& Development 14(5):1-27.

Van Houte, Marieke, and Tine Davids. 2008. "Development and Return Migration: from Policy Panacea to Migrant Perspective Sustainability." Third World Quarterly 29 (7):1411 1429.

Van Houte, Marieke, and Tine Davids. Forthcoming/a. "Moving Back or Moving Forward? Return Migration, Development and Peace-Building." Diversities.

Van Houte, Marieke, and Tine Davids. Forthcoming/b. "Love (n)or Marriage: How do Afghan Return Migrants from Europe Negotiate Belonging to One or Multiple Spaces of Embeddedness?".

Van Houte, Marieke, and Mireille De Koning. 2008. Towards a Better Embeddedness? Monitoring Assistance to Involuntary Returning Migrants from Western countries Nijmegen / Amsterdam: CIDIN / AMIDSt.

Van Houte, Marieke, Melissa Siegel, and Tine Davids. 2014. "Return to Afghanistan: Migration as Reinforcement of Socio-economic Stratification." Population, Space and Place. doi: 10.1002/psp.1876.

Van Houte, Marieke, Melissa Siegel, and Tine Davids. Forthcoming. "Deconstructing the Meanings of and Motivations for Return: An Afghan Case Study."

Van Liempt, Ilse. 2011. "Young Dutch Somalis in the UK: Citizenship, Identities and Belonging in a Transnational Triangle." Mobilities 6 (4):569-583. doi: 10.1080/17450101.2011.603948. 
Veale, Angela, and Emily Kennedy. 2011. "Indian Young People Negotiating Transnational Identities." In The Changing Faces of Ireland. Exploring the Lives of Immigrant and Ethnic Minority Children edited by Merike Darmody, Naomi Tyrrell and Steve Song, 53-69. Rotterdam: Sense.

Vertovec, Steven. 1999. "Conceiving and Researching Transnationalism." Ethnic and Racial Studies no. 22 (2):447-462. doi: 10.1080/014198799329558.

Vertovec, Steven. 2001. "Transnationalism and Identity." Journal of Ethnic and Migration Studies 27 (4):573-582. doi: 10.1080/13691830120090386.

Wahab, Abdul, Mahmud Ahmad, and Syed Akram Shah. 2006. "Migration as a Determinant of Marriage Pattern: Preliminary Report on Consanguinity Among Afghans." Journal of Biosocial Science 38 (03):315-325. doi:10.1017/S0021932005026404.

Wijers, Gea. 2013. Navigating a River by its Bends. A comparison of Cambodian Returnees Contributions to the Transformation of Cambodia, Faculty of Social Sciences, Free University, Amsterdam.

Wimmer, Andreas, and Nina Glick Schiller. 2003. "Methodological Nationalism, the Social Sciences, and the Study of Migration: An Essay in Historical Epistemology." International Migration Review 37 (3):576-610. doi: 10.1111/j.17477379.2003.tb00151.x.

Wissink, Marieke, Franck Düvell, and Anouka van Eerdewijk. 2013. "Dynamic Migration Intentions and the Impact of Socio-Institutional Environments: A Transit Migration Hub in Turkey." Journal of Ethnic and Migration Studies no. 39 (7):1087-1105. doi: 10.1080/1369183x.2013.778026.

Wolf, Siegfried 0. 2013. "Post-2014 Afghanistan: Future Scenarios from Structure and Agency Perspectives." Journal of South Asian Development 8 (2):233-254. doi: $10.1177 / 0973174113494602$.

Wood, Linda A., and Rolf O. Groger. 2000. Doing Discourse Analysis: Methods for Studying Action in Talk and Text Thousand Oaks, CA: Sage.

Zetter, Roger. 1999. "Reconceptualizing the Myth of Return: Contuity and Transition Amongst the Greek-Cypriot Refugees of 1974." Journal of Refugee Studies 12 (1):1-22. doi: 10.1093/jrs/12.1.1.

Zimmermann, Susan. 2012. "Understanding Repatriation: Refugee Perspectives on the Importance of Safety, Reintegration, and Hope." Population, Space and Place 18 (1):45-57. doi: $10.1002 / p s p .647$.

Zunzer, Wolfram. 2004. Diaspora Communities and Civil Conflict Transformation. In Berghof Occasional Paper. Berlin: Berghof Research Centre for Constructive Conflict Management. 


\section{Non-academic references}

AHRDO - The Afghanistan Human Rights and Democracy Organization. 2014. Infinite Incompleteness. A Documentary Theatre Play. PAJ 106: 94-112.

Eggers, David. 2002. You Shall Know Our Velocity. San Francisco: MacSweeneys.

Eggers, David. 2006. What is the What. San Francisco: MacSweeneys.

Hosseini, Khaled. 2013. And the Mountains Echoed. New York: Penguin.

Mason, Daniel. 2002. The Piano Tuner. New York: Random House.

Mercier, Pascal. 2004. Night Train to Lisbon. New York: Grove Press.

Smith, Zadie. 2000. White Teeth. London: Hamish Hamilton.

The Doors. 1967. People are Strange. In Strange Days: Elektra.

Wieringa, Tommy. 2012. Dit Zijn de Namen. Amsterdam: Bezige Bij. 



\section{Glossary}

This glossary includes definitions of the different categories of migration and return migration used in this thesis. The formulations are based on IOM's Glossary on Migration (2004), and adjusted when needed to match the views of this thesis.

Migrant - General term for a person who travels across an international border, or within a state. It encompasses any kind of movement of people, regardless of its length, composition and causes. Sub-categories based on reason for migration, such as economic migrants and forced migrants are subject to contestation and confusion, because these motivations are often mixed, as is argued throughout this thesis. Unless explicitly linked to one of the legal categories below, the respondents in this study are therefore referred to as migrants, when needed followed by from conflict areas.

Asylum seeker - A migrant who seeks safety from persecution or serious harm in a country other than his or her own, and awaits a decision on the application for refugee status under relevant international and national instruments.

Refugee - A migrant who has been granted refugee status by national or international procedures, based on the refugee convention: "owing to a wellfounded fear of persecution for reasons of race, religion, nationality, membership of a particular social group or political opinions, is outside the country of his nationality and is unable or, owing to such fear, is unwilling to avail himself of the protection of that country". (Art. 1(A)(2), Convention relating to the Status of Refugees, Art. 1A(2), 1951 as modified by the 1967 Protocol).

Undocumented migrant - A migrant who enters or stays in a country without the appropriate documentation.

Return migrant - A migrant who travels back to his or her country of origin, regardless of the length and motivation. The sub-categories of return based on motivation are contested in this thesis. Below, the alternative definitions used in this thesis, based on legal status, are given.

Voluntary return - Return of a migrant who does have a legal alternative to stay permanently in the country of residence. See chapter 5 .

Involuntary return - Return of a migrant who does not have a legal alternative to stay permanently in the host country. See chapter 5 . 
Independent involuntary return - Involuntary return of a migrant without the use of physical force, including return through 'Assisted Voluntary Return' programmes. See Chapter 6.

Assisted Voluntary Return - Programmes of administrative, logistical, financial and reintegration support to migrants unable and, or, unwilling to remain in the host country to return to their countries of origin.

Forced involuntary return - Involuntary return of a migrant with the use of physical force, such as deportation. See Chapter 6.

Deportation - The act of a State in the exercise of its sovereignty in removing a non-national from its territory to his or her country of origin or third state after refusal of admission or termination of permission to remain. 


\section{Valorization}

\section{Background}

This dissertation looks into the experience of migrants from conflict-affected countries and their development and peace-building potential upon return to the 'post-conflict' country of origin. The expectations of return migrants in debates on migration and development is contradictory: they are expected to both represent a movement back to the original, pre-conflict situation, and a movement forward, in which return migrants can contribute to positive change.

Although current policies suggest an inherent and positive link between return migration, development and peace-building, academic contributions to the discussion show that there is limited and contradictory empirical evidence on the nature, quality and direction of this link. Without theoretical and empirical foundation, the discussion on the relationship between migration, development and peace-building risks being reduced to a merely political and ideological issue that congeals into normative frames and produces inadequate policies. This thesis takes a transnational and multidimensional approach in order to overcome the dichotomies, generalizations and empirical shortcomings that surround the understanding of return migration within the migration-development-peace-building nexus.

\section{Relevance and innovativeness}

This thesis responds to a number of methodological, geographical, conceptual and empirical research gaps in research on return migration in the context of migration and development debates.

\section{Methodological}

Methodologically, this study meets the need for analytical tools that address the complexity and heterogeneity of return, by following the life course of return migrants in a mixed methods approach. Combining complementary approaches helped to come up with solid empirical data that can critically interrogate the assumptions that inform host governments' policies on return migration and development. While the comparative study highlighted some remarkable trends in return migration, the narrative as a research methodology in the in-depth case study proved to be a valuable research methodology for studying the complexity of migration.

\section{Geographical}

While research on return migration has so far mainly concentrated on African countries and the Balkans, Afghanistan as a case study is a relevant addition to the 
existing literature in the study of return migration, development and peace-building, for various reasons. First, the 35-year-long history of Afghan conflict and migration shows how the globally changing political discourses of the past decades have shaped migration strategies. Second, two major trigger events of this shifting discourse, the Cold War and the events of 11 September 2001, also played a direct and crucial role in the history of Afghanistan. Third, the fact that in 2014 all eyes are again on Afghanistan makes it a relevant and timely case to focus on. Whatever the outcome of this transition period, this thesis highlights that migration will certainly continue to play a crucial role in Afghan people's survival strategies in times of conflict and crisis. This thesis argues that instead of trying to manage and contain these migration flows, a way forward in the migration and development debate should be concentrating on how to facilitate this resilience and determination of people to find a better life.

\section{Conceptual}

This thesis further developed the concept of multidimensional and multi-local embeddedness as a holistic, transnational and multidimensional approach to the multi-sited experience of migration. This concept allows us to go beyond 'reintegration', as a measure for sustainable return. Embeddedness, defined as the process of an individual's identification with and participation in one or multiple spaces of belonging, merges understandings of transnationalism and integration into one analytical framework. In addition, it highlights the interplay between agency and structure and addresses the need for an encompassing perspective, taking into account complexity, contradictions and diversity, while preventing conceptual vagueness.

In addition, I introduced an analytical framework in order to deconstruct return migration as a complex decision-making process that goes beyond dichotomies of voluntary and involuntary mobility. The framework has the potential to be used in any context of migration and non-migration, in any degree of (in)voluntariness and in changing circumstances. It may be seen as a template of factors that should be taken into account in the study of migration, with the weight and direction of the linkages varying according to the research context.

\section{Empirical}

The thesis contributes to a number of research gaps that are highly relevant for policy on migration: Chapter 3 investigated whether the use of Official Development Assistance (ODA) for Assisted Voluntary Return (AVR) programmes for rejected asylum seekers and undocumented migrants is justified. It analysed the determinants of post-return embeddedness, showing a number of remarkable trends across the six very different countries in the study. The findings showed the limited or even negative impact of return assistance, and the significance of the migration cycle experience and in particular the return motivation. We found that returnees faced deprivation rather than benefitting from their migration experience. It is therefore unjustified and misleading to suggest that AVR programmes may promote development. 
In chapter 5 I therefore focused on the meanings of and motivations for return. The chapter highlighted the importance of post-return mobility, which I proposed to centralize in the study of return migration as an indicator of voluntary or involuntary return. Rather than formulating dichotomies, I argue that the policy and practice of migration would benefit from highlighting the complexities of migration. Analysing the complex meanings of and motivations for return can contribute to an understanding of why return assistance and policies fail and of how the needs and the potential of returnees can be better anticipated through improved policies.

In chapters 6 and 7 I interrogated the expectations of the debate on migration and development that returnees are positively selected, that they benefit from their migration experience and that they form hybrid identities so that they can negotiate change upon their return. Both chapters find that these expectations are too easily formulated and that their accuracy differs according to whether the return is voluntary or involuntary, with transnational mobility being the strongest differentiating factor. The findings therefore highlight the limitations of the applicability of return and development policies and restrict expectations of return migration and development.

In chapter 8 I projected these insights on returnees' identifications with the conflict. The chapter highlighted that policy makers' idea that migrants can and should be steered in the nature of their actions raises ethical and practical questions. With regard to the main question of this thesis on the circumstances under which return migrants are willing and able to contribute to development and peace-building, I highlighted the importance of human dynamics and transnational mobility.

\section{Target audience}

This thesis showed that while the bulk of the budgets for policies promoting migration and development go to de facto involuntary returnees, this group is unable to contribute to development in any way. The expectations on which migration and development policies are based only apply to a small minority of returnees, who are not the group that is targeted by the policies. I have shown that return migration is a complex process, to which contemporary policy is responding inadequately. This thesis shows that a thorough understanding of the heterogeneity of return migrants is essential for effective policy.

In addition to contributing to academic knowledge, this thesis therefore has a particularly urgent message to public policy makers in European and other 'industrialized' countries and civil society organizations. First, policy makers have not been responsive to arguments about the limited evidence on return and development and the need for careful wording and definitions regarding the nature of mobility. They are aware that using a vocabulary of 'voluntary return' and 'return migration and development' makes it easier to explain a politically sensitive topic to the public, and that framing the policy in this way enables them to use budgets assigned for development assistance for the return of unwanted migrants.

Second, NGOs whose primary goal is the wellbeing of migrants have now been incorporated into the migration and development discourse. NGOs who became involved in return assistance, as a way to 'do something for those who have to return', 
now have to comply with the terms of the governments' return policies in order to receive funding, which basically means that they have to produce a target number of returnees. While NGOs oriented towards migrants' wellbeing have an image of independence in society and among migrants, they are in fact implementing government policy for removing unwanted migrants. The pressure to market their product in what has been called the migration industry (Gammeltoft-Hansen and Sørensen 2012) leads to claims that they contribute to sustainable return or even to development. Such claims may, in turn, be used by governments to legitimize their return policies further.

I have argued that expressing these expectations in policy papers, statistics and other communications is, however, not harmless as it affects our thinking and debating about, and communication with, migrants. Their discontent after return as a result of miscommunication and disappointment about the reality of return, may have destabilizing effects, which undermines the goals of these policies. For NGOs and policy makers, it is important to acknowledge the real impact of return programmes on individual migrants and development in the country of origin, and to re-evaluate their roles in this process.

To undo the mismatch between policy and reality, and in order to formulate adequate policies that not only address the needs and potential of returnees, but also meet the goals of policy more adequately, I propose two modifications to current policy. First, to avoid further conceptual confusion, de facto involuntary return should no longer be called 'voluntary' but should be redefined in terms that do justice to reality (see chapter 5). Second, the multi-tool approach, in which an attempt was made to combine multiple goals into one return migration policy, has proved inadequate. Where different policy fields have sought cooperation and common ground, the results of this thesis urge them to critically review these linkages, and to re-evaluate and disentangle the different goals that inform migration and development policies.

\section{Outreach}

Next to writing this book, I have contributed to a significant number of outreach activities that intend to disseminate the results of this thesis among academics, policy makers and practitioners. First, this thesis has so far produced seven academic articles. Two of them have been published, three will be published within the coming months and two are currently under review. Second, I have presented and discussed the results of this thesis with both academic and policy-oriented audiences at national and international conferences and meetings. Third, I have shared my methodological experiences while teaching students of Maastricht University. Fourth, I wrote an article in Forced Migration Review, a highly influential policy and practice oriented magazine. In the near future, I will continue to disseminate the insights from this thesis in the public, policy and academic debate. 


\section{Samenvatting}

Dutch Summary

\section{Inleiding}

'Als migranten teruggaan naar huis na conflict, zullen ze bijdragen aan ontwikkeling en vredesopbouw in hun land van herkomst'. Dit optimistische mantra in het beleid van veel Europese landen, waaronder Nederland, is het voorlopige resultaat van de ontwikkelingen van de afgelopen 25 jaar in de realiteit van en het denken over migratie. Deze verwachting bevat een paradox: terugkeer na conflict wordt zowel gezien als een beweging terug naar de normale situatie, die verstoord was door conflict, en tegelijkertijd als vooruitgang, waarin terugkeermigranten bijdragen aan ontwikkeling en vredesopbouw in het land van herkomst. Drie soorten aannames liggen ten grondslag aan deze verwachting:

1. Van migranten die tot naar een Europees land hebben kunnen reizen wordt verwacht dat zij een speciale selectie van de totale populatie van het land van herkomst zijn: zij zijn hoger opgeleid, welvarender, ondernemender en hebben sterkere netwerken. Hun terugkeer is daarom hoe dan ook positief;

2. Een tweede verwachting is dat migratie bijdraagt aan capaciteitsopbouw; in het gastland kunnen migranten geld verdienen, werkervaring opdoen en ideeën opdoen over bijvoorbeeld democratie en transparantie, die ze bij terugkeer kunnen inzetten;

3. Ten derde wordt van deze migranten verwacht dat zij zich identificeren met zowel het land van herkomst als het gastland. Dit stelt hen in staat een brugfunctie tussen culturen te vervullen en zo verandering teweeg te brengen.

Hoewel de discussie over de relatie tussen migratie, ontwikkeling en vredesopbouw zich wereldwijd richt op succesvolle (economische) migranten, hebben verschillende landen in de Europese Unie dit verband uitgebreid naar de terugkeer van vluchtelingen, afgewezen asielzoekers en ongedocumenteerde migranten. Deze landen besteden grote delen van hun budgetten voor migratie en ontwikkeling, die betaald worden uit ontwikkelingsgeld (ODA), aan terugkeerassistentie (AVR) en asielen immigratiebeleid. Kleinere programma's steunen de tijdelijke terugkeer van hooggeschoolde migranten. Deze focus op terugkeer en ontwikkeling dient drie beleidsdoelen met betrekking tot migratie, ontwikkeling en veiligheid:

1. Het beheersen, controleren en reguleren van migratiestromen, door migranten die economisch en politiek overbodig zijn op een effectieve manier te laten terugkeren naar het land van herkomst;

2. Het beschermen van binnenlandse veiligheid en welzijn door de last van immigranten op gastlanden te verlichten en destabiliserende effecten van terugkeer op het land van herkomst en het gastland te voorkomen; 
3. Ontwikkeling en vredesopbouw bevorderen en een positieve connotatie geven aan de terugkeer van migranten; tegelijkertijd 'foute' ontwikkelingen, zoals revolutie, religieuze oppositie of politieke onrust voorkomen.

Het feit dat deze drie doelen in één beleid voor migratie en ontwikkeling samenkomen en ODA budgetten gebruikt worden voor terugkeerprogramma's roept vragen op. Ten eerste: hoe kan terugkeer zowel het herstel van de orde als een stimulans voor vooruitgang betekenen? Ten tweede: welke categorieën terugkeerders kunnen bijdragen aan wat voor soort verandering?

In dit proefschrift ga ik in op de contradicties en kennislacunes die bestaan in het debat over de relatie tussen terugkeermigratie, ontwikkeling en vredesopbouw. Ik beantwoord de vraag onder welke omstandigheden terugkeermigranten vanuit geïndustrialiseerde landen bereid en in staat zijn om bij te dragen aan ontwikkeling en vredesopbouw in het 'post-conflict' land van herkomst. In deze samenvatting bespreek ik hierna eerst het conceptuele kader, de gebruikte methoden en de geografische focus van deze studie, waarna ik de bevindingen, de conclusies en beleidsimplicaties ervan bespreek.

\section{Conceptueel kader}

In dit proefschrift introduceer ik het concept 'multidimensional embeddedness' als een holistisch begrip dat ruimte biedt aan de complexiteit, tegenstellingen en diversiteit van migratie, zonder te verzanden in conceptuele vaagheid. Ik definieer embeddedness als het proces waarin een individu zich identificeert met en participeert in een of meerdere 'spaces of belonging' ${ }^{37}$ Daarnaast introduceer ik in dit proefschrift een analytisch model om terugkeer als complex besluitvormingsproces te kunnen bestuderen. In dit model wordt zeggenschap over migatie gezien als de uitkomst van wensen en capaciteiten, die gevormd worden door structurele factoren. Dit model heeft de potentie om te worden gebruikt in onderzoek naar elke vorm van migratie.

\section{Methodologie}

In het onderzoek waar dit proefschrift op is gebaseerd heb ik de complexiteit van migratie en terugkeer bestudeerd door uit te gaan van een holistische benadering van de levensloop van terugkeermigranten. Het onderzoek bestaat uit twee complementaire onderzoeksfasen, die samen de algemene patronen en trends, maar ook de complexiteit en betekenis van terugkeermigratie bestuderen. De eerste fase was een vergelijkend onderzoek in 2007/2008 onder 178 terugkeermigranten in zes landen wereldwijd (Afghanistan, Armenië, Bosnië-Herzegovina, Sierra Leone, Togo en

\footnotetext{
37 Voor 'embeddedness' en 'spaces of belonging' bestaat geen goede Nederlandse vertaling. 'Embeddedness' betekent zoiets als 'ingebed zijn (in een samenleving)'. 'Space' staat voor een ruimte die niet aan geografische plaats gebonden hoeft te zijn: Het kan een land of stad zijn, maar ook bijvoorbeeld 'de internationale gemeenschap', of de Afghaanse diaspora. 'Belonging' betekent thuishoren, behoren tot.
} 
Vietnam), waarbij gestandaardiseerde vragenlijsten en semi-gestructureerde interviews gebruikt werden. De tweede fase was een casestudy in 2012 onder 35 terugkeermigranten in Afghanistan, bedoeld om dieper in te gaan op de patronen die voortkwamen uit het vergelijkende onderzoek. In deze fase werkte ik met semiongestructureerde interviews in de vorm van levensgeschiedenissen, groepsdiscussies en participatieve methoden.

\section{Afghanistan}

Waar onderzoek naar terugkeermigratie zich tot nu toe vooral op Afrikaanse landen en de Balkan concentreerde, is de keuze voor Afghanistan als casestudy een relevante toevoeging aan de bestaande literatuur, om verschillende redenen. Ten eerste laat het 35 jaar durende conflict en bijbehorende migratiegeschiedenis zien, hoe het veranderende politieke klimaat van de afgelopen decennia migratiestategieën heeft beïnvloed. Ten tweede spelen twee belangrijke gebeurtenissen die dit veranderende klimaat hebben gevormd, de Koude Oorlog en de gebeurtenissen van en na 11 September 2001, ook een cruciale rol in de geschiedenis van Afghanistan. Ten derde zorgt het transitiejaar 2014, waarin internationale troepen zich terugtrekken uit het land en alle ogen opnieuw op Afghanistan gericht zijn, ervoor dat het een actuele en relevante case is om te bestuderen.

\section{Resultaten}

\section{De bepalende factoren voor embeddedness na terugkeer}

Hoofdstuk 3 bespreekt de resultaten van het vergelijkende onderzoek in zes landen wereldwijd. We onderzochten of het gebruik van ontwikkelingsgeld voor AVRprogramma's voor afgewezen asielzoekers en ongedocumenteerde migranten gerechtvaardigd was. We analyseerden de factoren die een rol speelden voor embeddedness na terugkeer. De resultaten laten zowel contextspecifieke factoren als opmerkelijk sterke algemene trends zien in de zes zeer verschillende landen van terugkeer. Terwijl terugkeerassistentie een zeer beperkt of zelfs negatief effect heeft op embeddedness na terugkeer, spelen de omstandigheden tijdens migratie en in het bijzonder de motivatie om terug te keren, een grote rol. Een asielzoeker die jaren in het gastland leeft met beperkte rechten, ondervindt meer schadelijke effecten dan terugkeerassistentie kan goedmaken. De zeggenschap die migranten hebben over het besluit terug te keren speelt een grote rol in embeddedness na terugkeer. Het hoofdstuk concludeert dat het niet gerechtvaardigd en zelfs misleidend is om te suggereren dat terugkeerprogramma's zouden kunnen bijdragen aan ontwikkeling in het land van herkomst. 


\section{De betekenis van en motivaties voor terugkeer}

De bevinding dat de omstandigheden van migratie en motivatie voor terugkeer, meer dan terugkeerassistentie, van belang zijn bij terugkeer, vroeg om een verdere analyse van de betekenis van en de motivaties voor terugkeer. In hoofdstuk 5 stel ik het huidige onderscheid tussen vrijwillige en onvrijwillige terugkeer ter discussie, dat gemaakt wordt op basis van het al dan niet gebruiken van geweld. Ik beargumenteer dat er geen strakke grens, maar eerder een glijdende schaal tussen vrijwillige en onvrijwillige terugkeer bestaat, waarin zeggenschap over mobiliteit cruciaal is voor de terugkeerervaring. Terwijl ik pleit om de nuance in terugkeermotivaties in het oog te houden, stel ik daarom voor om vrijwillige of onvrijwillige terugkeer te herdefiniëren rondom mobiliteit: terugkeer is vrijwillig als een migrant een permanente status in het gastland heeft, die transnationale mobiliteit na terugkeer garandeert. Terugkeer is onvrijwillig als een migrant niet zo'n status heeft, wat de mogelijkheden om opnieuw te vertrekken sterk beperkt. De volgende twee hoofdstukken onderzoeken de verschillen tussen deze categorieën van terugkeerders met betrekking tot verwachtingen van migratie en ontwikkeling.

\section{De hiërarchisering van migratie}

Hoofdstuk 6 onderzoekt de sociaal-economische situatie onder vrijwillige en onvrijwillige terugkeermigranten. Anders dan de aannames die ten grondslag liggen aan migratie-en-ontwikkelingsbeleid, behoren niet alle migranten tot de elite, profiteren niet alle terugkeerders van hun migratie-ervaring en zijn ze niet allemaal even sterk ingebed in zowel het land van herkomst als het gastland. Migranten uit een hogere sociaal-economische klasse, hadden de mogelijkheid in een vroeg stadium van het conflict te vertrekken en hadden (daardoor) meer kans op een vluchtelingenstatus waardoor ze permanent in het land mochten blijven. Zij profiteerden van mogelijkheden om te werken en te studeren in Europa en keerden terug op een moment dat zij zelf kozen. Omdat ze in beide landen ingebed zijn, maken ze steeds opnieuw de keuze om te blijven of te vertrekken. Dit in tegenstelling tot migranten van meer bescheiden afkomst, die pas later konden vertrekken of pas in Europa arriveerden na jaren onderweg te zijn geweest. Zij maakten minder kans op een vluchtelingenstatus. In plaats daarvan leefden ze als asielzoeker of als ongedocumenteerde migrant met beperkte rechten in het gastland, voordat ze, onvrijwillig en verarmd, teruggingen. Zij kunnen geen banden met het gastland onderhouden, en ook hun positie in Afghanistan is verzwakt na terugkeer. Dit effect van migratie en terugkeer versterkt bestaande socio-economische verschillen. Deze bevinding beperkt de aanname dat migratie op zichzelf capaciteitsopbouwend is.

\section{Identiteit: laveren tussen 'spaces of belonging'}

Hoofdstuk 7 gaat in op de verwachting dat migranten een brugfunctie kunnen vervullen tussen culturen en door hun hybride identiteit verandering teweeg kunnen brengen. Het hoofdstuk onderzoekt hoe Afghanen die terugkeren vanuit Europa, 
laveren tussen verschillende spaces of belonging door middel van uitingen op het gebied van huwelijk, seksualiteit en gendernormen. Veel onvrijwillige terugkeermigranten, die vaak vooral in Afghanistan ingebed zijn, kiezen er voor om zich te schikken binnen de grenzen van de Afghaanse cultuur, als een manier om zich een plek binnen die structuur te verwerven. Daarentegen komen vrijwillige terugkeermigranten, die zich thuisvoelen in, en zich makkelijk kunnen bewegen tussen meerdere spaces of belonging, met creatieve, hybride oplossingen voor hun relationele leven. Tegelijkertijd laat het onderzoek zien dat ook deze terugkeerders niet willen, niet kunnen of het niet nodig hebben om de Afghaanse structuren te veranderen. De verwachte brugfunctie van deze migranten is daarom overschat.

\section{Terugkeerders 'for change'?}

Voortbouwend op eerdere hoofdstukken, die de beperkingen van de drie aannames over de eigenschappen van migranten aangaven, gaat hoofdstuk 8 concreet in op de relatie tussen terugkeermigratie, ontwikkeling en vredesopbouw. Het hoofdstuk bespreekt vier manieren waarop terugkeerders zich identificeren met het conflict: fysiek, institutioneel, psychologisch, en met betrekking tot de toekomst.

De conclusie van dit hoofdstuk is dat de enige terugkeerders die mogelijk zouden kunnen voldoen aan de verwachtingen van migratie, ontwikkeling en vredesopbouw, vrijwillige terugkeerders zijn. Hun embeddedness in en mobiliteit tussen meerdere spaces of belonging geeft hen het vertrouwen dat ze zichzelf en hun familie kunnen beschermen tegen geweld. Hun sterke banden met het Westen en hun positie als succesvolle terugkeerders brengen soms ook extra veiligheidsrisico's met zich mee. Jonge vrijwillige terugkeerders vonden een gevoel van belonging in de Afghaanse gemeenschap door dat risico te nemen. Zij kunnen gezien worden als pioniers die gebruik maken van de kansen in een opkomende markt met weinig competitie.

Veel van deze vrijwilige terugkeerders werden gedreven door ambitie en kozen ervoor om terug te gaan ondanks de instabiele situatie. Zij keerden terug met optimisme, energie en een pro-actieve houding, wat een frisse inbreng is in de door conflict verscheurde Afghaanse samenleving. Zij willen modernisering brengen, waarin ze hun kennis, vaardigheden en mentaliteit uit Europa als een toegevoegde waarde zien. Ze merken echter ook dat veel van deze 'buitenlandse' ideeën in Afghanistan met argwaan bekeken worden. Het vereist geduld en sociale vaardigheden om deze ideeën door te voeren, waardoor weinig van deze inspanningen echt verandering teweeg brengen. Vrijwillige terugkeerders heroverwegen voortdurend hun beslissing om te blijven of te vertrekken, en het ligt voor de hand dat ze zullen re-emigreren als het conflict opnieuw oplaait. Deze zelfde mobiliteit zorgt er echter voor dat ze risico's konden nemen om 'anders' te zijn dan de dominante samenleving.

Onvrijwillige terugkeerders, daarentegen, zijn meestal op geen enkele manier van toegoevoegde waarde voor Afghaanse vredesopbouw en ontwikkeling. De meesten van hen keren gefrustreerd en verarmd terug. Omdat ze niet genoeg middelen hebben om zichzelf en hun familie te beschermen, en niet gemakkelijk konden vertrekken als dit nodig is, voelen ze zich blootgesteld aan geweld. Ze hebben niet veel nieuwe vaardigheden of ideeën opgedaan en neigen eerder naar de 
conservatieve en traditionele kant als strategie van belonging. Het feit dat ze een groot deel van hun leven, ook tijdens hun tijd in Europa, in onzekerheid hebben geleefd, en de verwachting van toenemende onveiligheid na 2014, tast hun geestelijke gezondheid aan. Veel van hen trekken zich eerder terug dan dat ze proberen verandering te brengen.

Deze bevindingen benadrukken, ten eerste, het belang van de menselijke dimensie van de betrokkenheid van terugkeerders. Ten tweede tonen ze aan dat transnationale mobiliteit de sterkste toegevoegde waarde is van migranten, die hen kan helpen om beperkingen te overwinnen en behoedzaam verandering teweeg te brengen, dan een zwakte die hun fluïde betrokkenheid impliceert.

\section{Conclusie}

Op basis van bovenstaande bevindingen concludeer ik dat terugkeermigratie niet gelijkstaat aan terugkeer naar 'normaal', maar ook niet gemakkelijk vooruitgang is. De relatie tussen migratie, ontwikkeling en vredesopbouw is te complex voor generalisaties. Dit proefschrift toont een discrepantie tussen de toekenning van ontwikkelingsbudget enerzijds en het ontwikkelingspotentieel van terugkeermigranten anderzijds: terwijl het overgrote deel van budget voor migratie en ontwikkeling naar de facto onvrijwillige terugkeerders gaat, is deze groep niet in staat om bij te dragen aan ontwikkeling of vredesopbouw. Integendeel: dit potentieel wordt ondermijnd door restrictief asielbeleid. Hoewel een deel van de vrijwillige terugkeerders wel een potentiële bijdrage zou kunnen leveren, gaat maar een klein aandeel van het totale budget naar inititatieven van deze groep.

\section{Beleidsaanbevelingen}

Zowel beleidsmakers als organisaties uit het maatschappelijk middenveld reageren pragmatisch op de discrepantie tussen beleid en realiteit. Beleidsmakers gebruiken een vocabulaire van 'vrijwillige terugkeer' en 'terugkeer en ontwikkeling' om een politiek gevoelig onderwerp gemakkelijker uit te leggen, en om ontwikkelingsbudget te gebruiken voor de terugkeer van ongewenste migranten. NGO's met migranten als doelgroep, begonnen met terugkeerassistentie met als doel om 'iets te doen voor hen die toch terug moeten'. Gaandeweg zijn zij opgenomen in het migratie-enontwikkelingsdiscours. Zij moeten voldoen aan de regels die gesteld zijn door het terugkeerbeleid van de overheid, om financiering voor hun projecten te kunnen ontvangen. Dit betekent in de praktijk dat ze een quotum van een aantal terugkeerders moeten halen. Terwijl NGO's een onafhankelijk imago hebben, voeren ze in feite terugkeerbeleid van de overheid uit. De druk om hun product aan te prijzen in wat de 'migratie-industrie' genoemd wordt, verleidt hen tot uitspraken over hun bijdrage aan duurzame terugkeer en zelfs ontwikkeling. Zulke claims kunnen, vervolgens, gebruikt worden door overheden om hun terugkeerbeleid verder te legitimeren.

Het scheppen van verwachtingen over terugkeer en ontwikkeling beïnvloedt de discussie over en de communicatie met migranten. Als gewekte verwachtingen niet 
blijken te stroken met de realiteit na terugkeer, leidt dit tot woede en frustratie. Deze ontevredenheid kan een destabiliserende factor kan zijn na terugkeer, wat de doelen van het terugkeerbeleid ondermijnt. Beleidsmakers en NGO's moeten daarom, zowel om morele als pragmatische redenen, realistischer zijn over de echte impact van terugkeerprogramma's op indidividuele migranten en ontwikkeling in het land van herkomst, en hun rol in dit proces herzien.

Om de discrepantie tussen beleid en realiteit ongedaan te maken, en om adequaat beleid te formuleren dat de behoeften van terugkeerders, maar ook de doelen van beleid beter tegemoet komt, doe ik in dit proefschrift twee beleidsaanbevelingen. Ten eerste: om verdere conceptuele verwarring te vermijden, moet de facto onvrijwillige terugkeer niet langer 'vrijwillig' genoemd worden, maar geherformuleerd worden in termen die recht doen aan de realiteit. Ten tweede: aangezien de poging om drie verschillende doelen te verenigen in een beleid voor migratie en ontwikkeling inadequaat is gebleken, is het tijd om de verschillende doelen, behoeftes en budgetten te ontwarren.

Het eerste doel om migratie te reguleren, impliceert de behoefte om ongewenste migranten effectief te laten vertrekken. Omdat uitzetting zowel financieel als politiek kostbaar en ineffectief is, kan het soms beter werken om migranten te overtuigen om terug te gaan. Het tweede doel om veiligheid en welzijn te garanderen, impliceert de behoefte om destabiliserende effecten van terugkeer te voorkomen. Aan deze beide doelen en hun behoeftes kan voldaan worden door een financiële of 'in-kind' compensatie voor onvrijwillige terugkeer van ongewenste migranten. Voor het derde doel om de potentiele bijdrage van migranten aan ontwikkeling en vredesopbouw in het land van herkomst te promoten, moet mobiliteit juist gefaciliteerd in plaats van tegengehouden worden. Bovendien vraagt dit om investering in de capaciteitsopbouw van migranten.

De verschillende doelen, behoeften en doelgroepen impliceren het gebruik van verschillende budgetten: als terugkeer is bedoeld voor de eerste twee doelen, is dit een kwestie van binnenlandse zaken of veiligheidsbudgetten. Alleen als terugkeer plaatsvindt onder de voorwaarden van gecontinueerde transnationale mobiliteit en het versterken van capaciteit, heeft ze de potentie om bij te dragen aan ontwikkeling en vredesopbouw, wat financiering uit ODA-budgetten zou rechtvaardigen.

Dit proefschrift richt zich voornamelijk op de case van Afghanistan. De toekomst van het land en de consequenties daarvan voor migratie zijn onduidelijk, wat ook geldt voor andere landen in de regio die op dit moment in crisis zijn. Wat zeker is, is dat migratie altijd onderdeel zal zijn van overlevingsstrategieën van mensen. Om de relatie tussen migratie en ontwikkeling te stimuleren zou, in plaats van te proberen deze migratiestromen te controleren en te beheersen, de veerkracht en vastberadenheid van mensen om een beter leven te vinden, moeten worden gefaciliteerd. 



\section{About the author}

Marieke van Houte (Roosendaal, 1983) completed her Bachelor's (2005) and Master's (2006) degree in Cultural Anthropology and Development Studies at Radboud University Nijmegen. Her Master's thesis was on return migration to Bosnia and Herzegovina. Since then, she has worked on issues of migration and development for academic, non-governmental and international organizations. Her interest in the complexity of migration has taken her to a diversity of research settings around the world, including Afghanistan, Bosnia and Herzegovina, Burundi, DR Congo, Iraq, Pakistan, Rwanda, Sierra Leone and Vietnam. In 2013, she joined the Maastricht Graduate School of Governance to write her PhD thesis. Marieke currently works for the OECD on a research project on migration and development. From January 2015, she will be connected to the International Migration Institute at the University of Oxford as a research officer. In her current and future work, she aims to continue doing migration research that is relevant to academic, policy and wider audiences, and expand her expertise on qualitative and participatory research methods. 


\section{MGSoG Dissertation Series}

Oxana Slobozhan

Global Governance in the Management of Natural Resources:

The Case of the Extractive Industries Transparency Initiative (EITI)

MGSoG Dissertation Series, nr 47 (2014)

Luis Bernardo Mejia Guinand

The Changing Role of the Central Planning Offices in Latin America:

A Comparative Historical Analysis Perspective (1950-2013)

MGSoG Dissertation Series, nr 46 (2014)

Cheng Boon Ong

Ethnic Segregation in Housing, Schools and Neighbourhoods in the Netherlands

MGSoG Dissertation Series, nr 45 (2014)

Luciana V. Cingolani

Bureaucracies for Development: Oxymoron or Reality?

Studies on State Capacity in Challenging Governance Contexts

MGSoG Dissertation Series, nr 44 (2014)

Carlos Cadena Gaitán

Green Politics in Latin American Cities - Sustainable Transport Agendas

MGSoG Dissertation Series, nr 43 (2014)

Katie Kuschminder

Female Return Migration and Reintegration Strategies in Ethiopia

MGSoG Dissertation Series, nr 42 (2014)

Metka Hercog

Highly-Skilled Migration and New Destination Countries

MGSoG Dissertation Series, nr 41 (2014)

Margaret Agaba Rugadya

Can Remittances Influence the Tenure and Quality of Housing in Uganda?

MGSoG Dissertation Series, nr 40 (2014)

Ilire Agimi

New Governance Under Limited Statehood

The Case of Local Government Reform in Kosovo

MGSoG Dissertation Series, nr 39 (2014)

Kristine Farla

Empirical Studies on Institutions, Policies and Economic Development

MGSoG Dissertation Series, nr 38 (2013)

Marina Petrovic

Social Assistance and Activation in the Pursuit of Happiness:

Shedding New Light on Old Policy Solutions to Social Exclusion

MGSoG Dissertation Series, nr 37 (2013) 
Laura Torvinen

Assessing Governance Assessments; The Case of Mozambique

Governance Assessments in the Context of Aid Effectiveness Discourse

MGSoG Dissertation Series, nr 36 (2013)

Biniam Egu Bedasso

Institutional Change in the Long Shadow of Elites

Essays on Institutions, Human Capital and Ethnicity in Developing Countries

MGSoG Dissertation Series, nr 35 (2013)

Sepideh Yousefzadeh Faal Deghati

Childhoods Embargoed

Constructing and Reconstructing Multidimensional Child Poverty in Iran 1984-2009

MGSoG Dissertation Series, nr 34 (2013)

Robert Bauchmüller

Investing in Early Childhood Care and Education:

The Impact of Quality on Inequality

MGSoG Dissertation Series, nr 33 (2013)

Martin Rehm

Unified Yet Separated

Empirical Study on the Impact of Hierarchical Positions within Communities of Learning

MGSoG Dissertation Series, nr 32 (2013)

Dorcas Mbuvi

Utility Reforms and Performance of the Urban Water Sector in Africa

MGSoG Dissertation Series, nr 31 (2012)

Lina Salanauskaite

Distributional Impacts of Public Policies:

Essays in EX-Ante and Ex-Post Evaluation

MGSoG Dissertation Series, nr 30 (2012)

Esther Schüring

To Condition or not - is that the Question?

An Analysis of the Effectiveness of Ex-Ante and Ex-Post Conditionality in Social Cash Transfer

Programs

MGSoG Dissertation Series, nr 29 (2012)

Joe Abah

Strong Organisations in Weak States

Atypical Public Sector Performance in Dysfunctional Environments

MGSoG Dissertation Series, nr 28 (2012)

Zina Samih Nimeh

Social Citizenship Rights: Inequality and Exclusion

MGSoG Dissertation Series, nr 27 (2012)

Lenka Eisenhamerová

Legitimacy of 'Humanitarian Military Intervention'

MGSoG Dissertation Series, nr 26 (2011) 
Sonila Tomini

Informal Payments for Health Care Services in Albania

MGSoG Dissertation Series, nr 25 (2011)

Jinjing Li

Dynamic Microsimulation in Public Policy Evaluation

MGSoG Dissertation Series, nr 24 (2011)

Aziz Atamanov

Rural Nonfarm Employment and International Migration as Alternatives to Agricultural

Employment:

The Case of Kyrgyztan

MGSoG Dissertation Series, nr 23 (2011)

Frieda Vandeninden

Poverty Alleviation: Aid and Social Pensions

MGSoG Dissertation Series, nr 22 (2011)

Juliana Nyasha Tirivayi

The Welfare Effects of Integrating AIDS Treatment with Food Transfers:

Evidence from Zambia

MGSoG Dissertation Series, nr 21 (2011)

Agnieska Ewa Sowa

Who's Left Behind? Social Dimensions of Health Transition and Utilization of Medical Care in

Poland

MGSoG Dissertation Series, nr 20 (2011)

Emmanaouil Sfakianakis

The Role of Private Actors in the Provision of Public Goods with Applications to Infrastructure and Financial Stability

MGSoG Dissertation Series, nr 19 (2011)

Siu Hing Lo

White Collars Green Sleeves

An Interonganizational Compariso of Deteminants of Energie-Related Behaviors among Office

Workers

MGSoG Dissertation Series, nr 18 (2011)

Treena $\mathrm{Wu}$

Constraints to Human Capital Investment in Developing Countries:

Using the Asian Financial Crisis in Indonesia as a Natural Experiment

MGSoG Dissertation Series, nr 17 (2011)

Henry Espinoza Peña

Impact Evaluation of a Job-Training Programme for Disadvantaged Youths:

The Case of Projoven

MGSoG Dissertation Series, nr 16 (2011)

Florian Tomini

Between Family and Friends

Understanding the Interdependency of Private Transfers

MGSoG Dissertation Series, nr 15 (2010) 
Michał Polalowski

The Institutional Transformation of Social Policy in East Central Europe:

Poland and Hungary in comparative and historical perspective

MGSoG Dissertation Series, nr 14 (2010)

Maha Ahmed

Defining, Measuring and Adressing Vulnerability:

The Case of Post Conflict Environments

MGSoG Dissertation Series, nr 13 (2010)

Pascal Beckers

Local Space and Economic Success

The role of spatial segregation of migrants in the Netherlands

MGSoG Dissertation Series, nr 12 (2010)

Victor Cebotari

Complicting Demands in Ethnically Diverse Societies

Ethnopolitical Contention and Identity Values in Europe

MGSoG Dissertation Series, nr 11 (2010)

Dennis Gyllensporre

Competing and Complementary Perspectives on the EU as a Crisis Management Actor:

An Examination of the Common Security and Defence Policy through the Lenses of Idealism and Realism

MGSoG Dissertation Series, nr 10 (2010)

Judit Vall Castello

Business Cycle and Policy Effects on Labour Market Transitions of Older and Disabled Workers in Spain

MGSoG Dissertation Series, nr. 9 (2010)

Keetie Roelen

False Positives or Hidden Dimentions: the definition and measurement of child poverty

MGSoG Dissertation Series, nr. 8 (2010)

Denisa Maria Sologon

Earning Dynamics in Europe

MGSoG Dissertation Series, nr. 7 (2010)

Melissa Siegel

Money and Mobility: Migration and Remittances

MGSoG Dissertation Series, nr. 6 (2010)

Jessica S. Hagen-Zanker

Modest Expectations: Causes and effects of migration on migrant households in source countries

MGSoG Dissertation Series, nr. 5 (2010)

Mirtha R. Muniz Castillo

Human Development and Autonomy in Project Aid: Experiences from four bilateral projects in Nigaragua and El Salvador

MGSoG Dissertation Series, nr. 4 (2009) 
MGSoG Dissertation Series

Christiane Arndt

Governance Indicators

MGSoG Dissertation Series, nr. 3 (2009)

Britta Augsburg

Microfinance - Greater Good or Lesser Evil?

MGSoG Dissertation Series, nr. 2 (2009)

Geranda Notten

Measuring and Managing Poverty Risks

MGSoG Dissertation Series, nr. 1 (2008) 